MARCHANT

ALFRED

RUSSEL

WALLACE:

LETTERS

AND

REMINSGENCES

$$
\begin{gathered}
Q H \\
31 \\
W 2 \\
A 4 \\
\text { v. } 1
\end{gathered}
$$




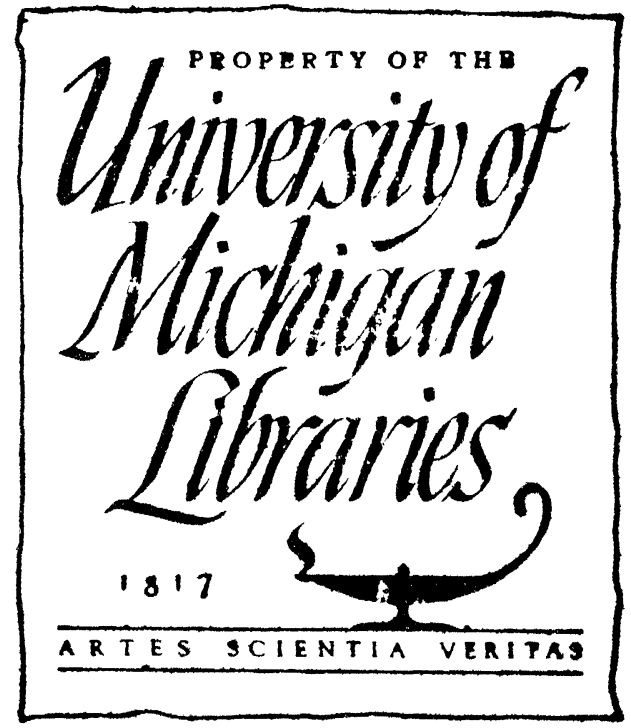




-..?

?*・

$\therefore \cdots$ 


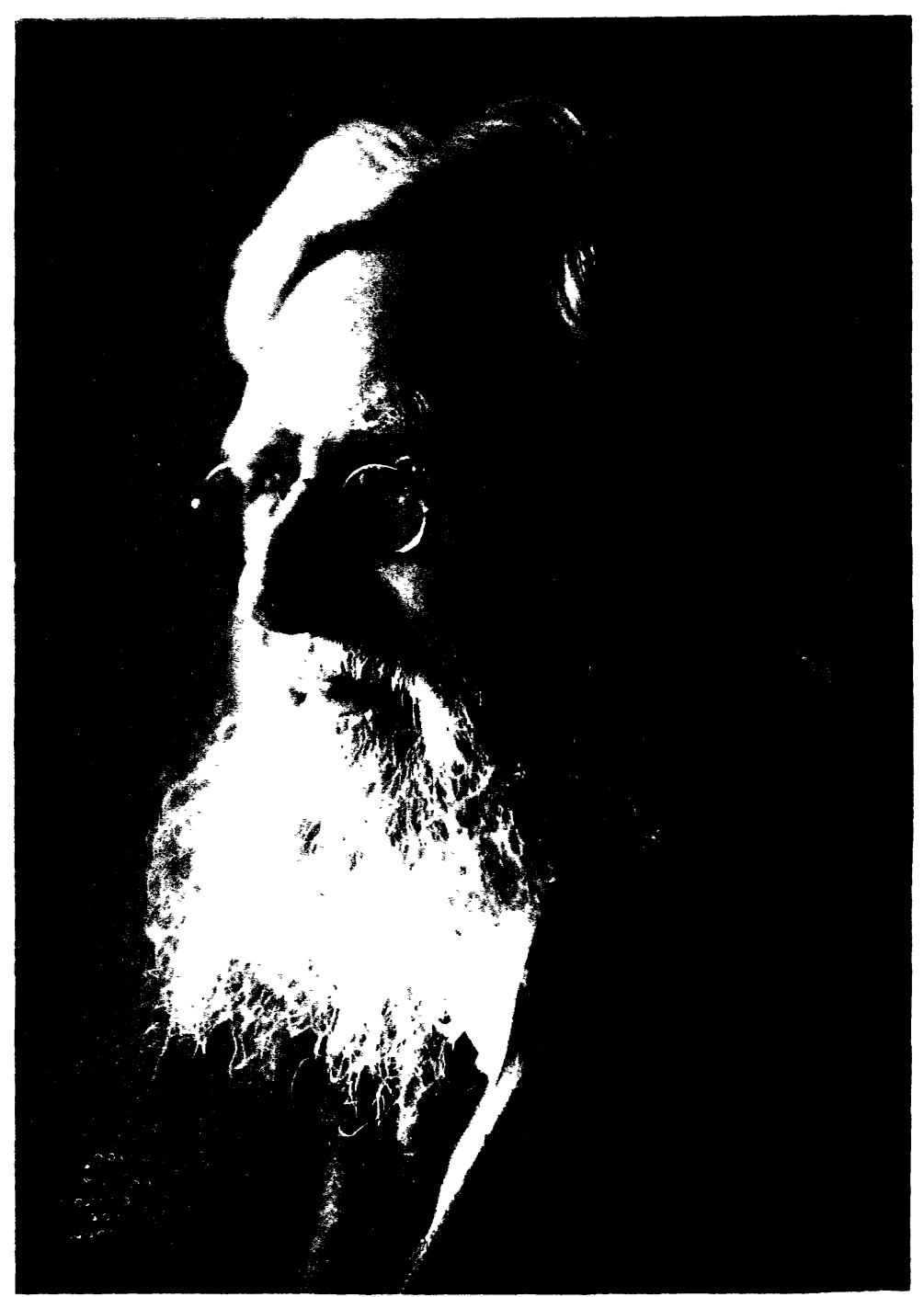

Photo E O Hoppé (1912)

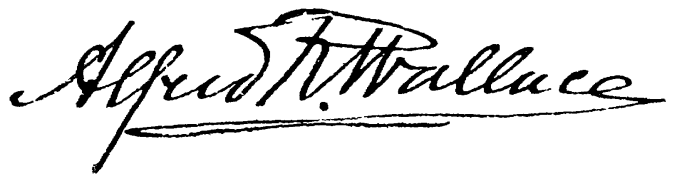




\title{
Alfred Russel Wallace Letters and Reminiscences
}

\author{
By \\ James Marchant

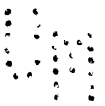

With Two Photogravures and Eight Half-tone Plates

$$
\text { IN Two Volumes }
$$

Volume I

CASSELL AND COMPANY, LTD

London, New York, Toronto and Melbourne 1916 


$$
\begin{aligned}
& 64 \\
& 31 \\
& 12 \\
& 61
\end{aligned}
$$$$
\begin{gathered}
n \\
\vdots \vdots \\
\vdots \\
\vdots
\end{gathered}
$$ 
To the Memory of ANNIE WALLACE 



\section{PREFACE}

THESE two volumes consist of a selection from several thousands of letters entrusted to me by the Wallace family and dating from the dawn of Darwinism to the second decade of the twentieth century, supplemented by such biographical particulars and comments as are required for the elucidation of the correspondence and for giving movement and continuity to the whole.

The wealth and variety of Wallace's own correspondence, excluding the large collection of letters which he received from many eminent men and women, and the necessity for somewhat lengthy introductions and many annotations, have expanded the work to two (there was, indeed, enough good material to make four) volumes. The family has given me unstinted confidence in using or rejecting letters and reminiscences, and although $\mathrm{I}$ have consulted scientific and literary friends, I alone must be blamed for sins of omission or commission. Nothing has been suppressed in the unpublished letters, or in any of the letters which appear in these volumes, because there was anything to hide. Everything Wallace wrote, all his private letters, could be published to the world. His life was an open book" no weakness, no contempt, dispraise, or blame, nothing but well and fair."

The profoundly interesting and now historic correspondence between Darwin and Wallace, part of which has already appeared in the "Life and Letters of Charles Darwin" and "More Letters," and part in Wallace's autobiography, entitled "My Life," is here published, with new vii 


\section{Preface}

additions, for the first time as a whole, so that the reader now has before him the necessary material to form a true estimate of the origin and growth of the theory of Natural Selection, and of the personal relationships of its noble codiscoverers.

My warmest thanks are offered to Sir Francis Darwin for permission to use his father's letters, for his annotations, and for rendering help in checking the typescript of the Darwin letters ; to Mr. John Murray, C.V.O., for permission to use letters and notes from the "Life and Letters of Charles Darwin" and from "More Letters"; to Messrs. Chapman and Hall for their great generosity in allowing the free use of letters and material in Wallace's "My Life"; to Prof. E. B. Poulton, Prof. Sir W. F. Barrett, Sir Wm. Thiselton-Dyer, Dr. Henry Forbes, and others for letters and reminiscences; and to Prof. Poulton for reading the proofs and for valuable suggestions. An intimate chapter on Wallace's Home Life has been contributed by his son and daughter, Mr. W. G. Wallace and Miss Violet Wallace.

J. M.

March, 1916. 


\title{
CONTENTS
}

\author{
Volume I
}

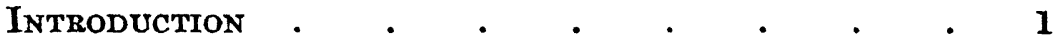

PART I

I. Wallace and Darwin-Eariy Years a $\quad 5$

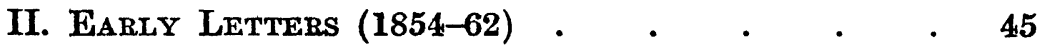

\section{PART II}

I. The Discovery of Natural Selection $\quad$ - $\quad 89$

II. The Complete Extant Correspondence between

Wallace and Darwin (1857-81) • . . 127

\section{Volume II}

\section{PART III}

I. Wallace's Works on Brology and Geographical

PAGE

Distribution $\quad . \quad$.

II. Correspondence on Biology, Geographical DisTRIBUTION, ETC. (1864-93) • • • • • 18

III. Correspondence on Brology, Geographical DisTRIBUtion, ETC. $(1894-1913)$ • $\quad$ • $\quad$ • $\quad 59$ 


\section{Contents}

\section{PART IV}

HOME LIFE

\section{PART V}

Soctal and Political Views $\quad$ • $\quad$ • $\quad$ • $\quad$ • $\quad$ - 139

\section{PART VI}

Some Further Problems

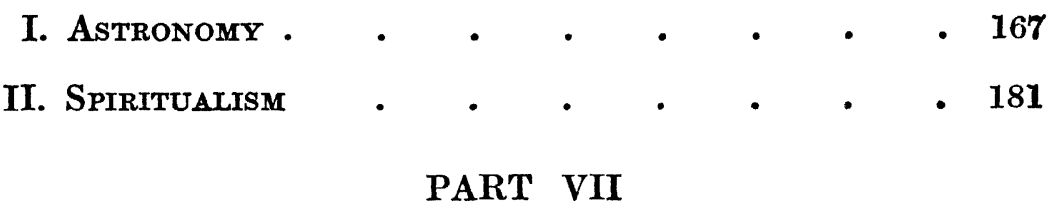

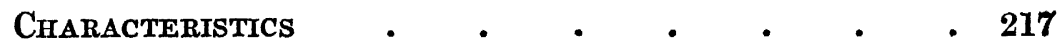

ApPENDix : Lists of Wallace's Writings • • 257

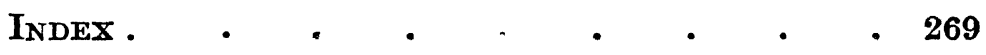




\section{LIST OF PLATES IN VOLUME I}

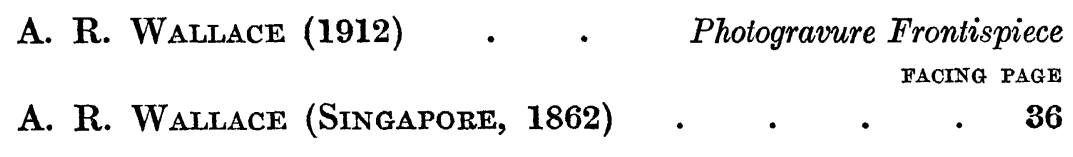

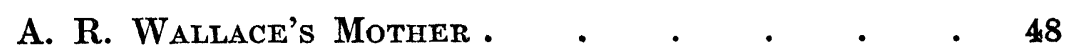

A. R. Wallace soon after his Return from the

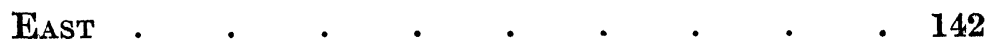





\section{Alfred Russel Wallace}

Letters and Reminiscences

\section{INTRODUCTION}

$\mathbf{I}$

N Westminster Abbey there repose, almost side by side, by no conscious design yet with deep significance, the mortal remains of Isaac Newton and of Charles Darwin. " "The Origin of Species,", said Wallace, "will live as long as the 'Principia' of Newton." Near by are the tombs of Sir John Herschel, Lord Kelvin and Sir Charles Lyell; and the medallions in memory of Joule, Darwin, Stokes and Adams have been rearranged so as to admit similar memorials of Lister, Hooker and Alfred Russel Wallace. Now that the plan is completed, Darwin and Wallace are together in this wonderful galaxy of the great men of science of the nineteenth century. Several illustrious names are missing from this eminent company; foremost amongst them being that of Herbert Spencer, the lofty master of that synthetic philosophy which seemed to his disciples to have the proportions and qualities of an enduring monument, and whose incomparable fertility of creative thought entitled him to share the throne with Darwin. It was Spencer, Darwin, Wallace, Hooker, Lyell and Huxley who led that historic movement which garnered the work of Lamarck and Buffon, and gave new direction to the ceaseless interrogation of nature to discover the "how" and the "why" of the august progression of life. 


\section{Alfred Russel Wallace}

Looking over the long list of the departed whose names are enshrined in our Minster, one has sorrowfully to observe that contemporary opinion of their place in history and abiding worth was not infrequently astray; that memory has, indeed, forgotten their works; and their memorials might be removed to some cloister without loss of respect for the dead, perhaps even with the silent approval of their own day and generation could it awake from its endless sleep and review the strange and eventful course of human life since they left "this bank and shoal of time." But may it not be safely prophesied that of all the names on the starry scroll of national fame that of Charles Darwin will, surely, remain unquestioned? And entwined with his enduring memory, by right of worth and work, and we know with Darwin's fullest approval, our successors will discover the name of Alfred Russel Wallace. Darwin and Wallace were pre-eminent sons of light.

Among the great men of the Victorian age Wallace occupied a unique position. He was the co-discoverer of the illuminating theory of Natural Selection; he watched its struggle for recognition against prejudice, ignorance, ridicule and misrepresentation; its gradual adoption by its traditional enemies; and its final supremacy. And he lived beyond the hour of its signal triumph and witnessed the further advance into the same field of research of other patient investigators who are disclosing fresh phases of the same fundamental laws of development, and are accumulating a vast array of new facts which tell of still richer light to come to enlighten every man born into the world. To have lived through that brilliant period and into the second decade of the twentieth century; to have outlived all contemporaries, having been the co-revealer of the greatest and most far-reaching generalisation in an era which abounded in fruitful discoveries and in revolutionary 


\section{Introduction}

advances in the application of science to life, is verily to have been the chosen of the gods.

Who and what manner of man was Alfred Russel Wallace? Who were his forbears? How did he obtain his insight into the closest secrets of nature? What was the extent of his contributions to our stock of human knowledge? In which directions did he most influence his age? What is known of his inner life? These are some of the questions which most present-day readers and all future readers into whose hands this book may come will ask.

As to his descent, his upbringing, his education and his estimate of his own character and work, we can, with rare good fortune, refer them to his autobiography, in which he tells his own story and relates the circumstances which, combined with his natural disposition, led him to be a great naturalist and a courageous social reformer; nay more, his autobiography is also in part a peculiar revelation of the inner man such as no biography could approach. We are also able to send inquirers to the biographies and works of his contemporaries-Darwin, Hooker, Lyell, Huxley and many others. All this material is already available to the diligent reader. But there are other sources of information which the present book discloses-Wallace's home life, the large collection of his own letters, the reminiscences of friends, communications which he received from many coworkers and correspondents which, besides being of interest in themselves, often cast a sidelight upon his own mind and work. All these are of peculiar and intimate value to those who desire to form a complete estimate of Wallace. And it is to help the reader to achieve this desirable result that the present work is published.

It may be stated here that Wallace had suggested to the present writer that he should undertake a new work, to be 


\section{Alfred Russel Wallace}

called "Darwin and Wallace," which was to have been a comparative study of their literary and scientific writings, with an estimate of the present position of the theory of Natural Selection as an adequate explanation of the process of organic evolution. Wallace had promised to give as much assistance as possible in selecting the material without which the task on such a scale would obviously have been impossible. Alas! soon after the agreement with the publishers was signed and in the very month that the plan of the work was to have been shown to Wallace, his hand was unexpectedly stilled in death; and the book remains unwritten. But as the names of Darwin and Wallace are inseparable even by the scythe of time, a slight attempt is here made, in the first sections of Part I. and Part II., to take note of their ancestry and the diversities and similarities in their respective characters and environments-social and educational; to mark the chief characteristics of their literary works and the more salient conditions and events which led them, independently, to the idea of Natural Selection.

Finally, it may be remarked that up to the present time the unique work and position of Wallace have not been fully disclosed owing to his great modesty and to the fact that he outlived all his contemporaries. "I am afraid," wrote Sir W. T. Thiselton-Dyer to him in one of his letters (1893), "the splendid modesty of the big men will be a rarer com. modity in the future. No doubt many of the younger ones know an immense deal; but I doubt if many of them will ever exhibit the grasp of great principles which we owe to you and your splendid band of contemporaries." If this work helps to preserve the records of the influence and achievements of this illustrious and versatile genius and of the other eminent men who brought the great conception of Evolution to light, it will surely have justified its existence. 


\section{PART I}

\section{1.-Wallace and Darwin-Early Years}

$A^{8}$

springs burst forth, now here, now there, on the mountain side, and find their way together to the vast ocean, so, at certain periods of history, men destined to become great are born within a few years of each other, and in the course of life meet and mingle their varied gifts of soul and intellect for the ultimate benefit of mankind. Between the years 1807 and 1825 at least eight illustrious scientists "saw the light"-Sir Charles Lyell, Sir Joseph Hooker, T. H. Huxley, Herbert Spencer, John Tyndall, Charles Darwin, Alfred Russel Wallace and Louis Agassiz; whilst amongst statesmen and authors we recall Bismarck, Gladstone, Lincoln, Tennyson, Longfellow, Robert and Elizabeth Browning, Ruskin, John Stuart Blackie and Oliver Wendell Holmes-a wonderful galaxy of shining names.

The first group is the one with which we are closely associated in this section, in which we have brought together the names of Charles Darwin and Alfred Russel Wallacebetween whose births there was a period of fourteen years, Darwin being born on the 12th of February, 1809, and Wallace on the 8th of January, 1823.

In each case we are indebted to an autobiography for an account of their early life and work, written almost entirely from memory when at an age which enabled them to take an unbiased view of the past.

The autobiography of Darwin was written for the benefit of his family only, when he was 67 ; while the two 


\section{Alfred Russel Wallace}

large volumes entitled "My Life" were written by Wallace when he was 82 , for the pleasure of reviewing his long career. These records are characterised by that charming modesty and simplicity of life and manner which was so marked a feature of both men.

In the circumstances surrounding their early days there was very little to indicate the similarity in character and mental gifts which became so evident in their later years. A brief outline of the hereditary influences immediately affecting them will enable us to trace something of the essential differences as well as the similarities which marked their scientific and literary attainments.

The earliest records of the Darwin family show that in 1500 an ancestor of that name (though spelt differently) was a substantial yeoman living on the borders of Lincolnshire and Yorkshire. In the reign of James I. the post of Yeoman of the Royal Armoury of Greenwich was granted to William Darwin, whose son served with the Royalist Army under Charles I. During the Commonwealth, however, he became a barrister of Lincoln's Inn, and later the Recorder of the City of Lincoln.

Passing over a generation, we find that a brother of Dr. Erasmus Darwin "cultivated botany," and, when far advanced in years, published a volume entitled "Principia Botanica," while Erasmus developed into a poet and philosopher. The eldest son of the latter "inherited a strong taste for varioug branches of science . . . and at a very early age collected specimens of all kinds." The youngest son, Robert Waring, father of Charles Darwin, became a successful physician, "a man of genial temperament, strong character, fond of society," and was the possessor of great psychic power by which he could readily sum up the characters of others, and even occasionally read their thoughts. A judicious use of this gift was frequently 


\section{Early Years}

found to be more efficacious than actual medicine! To the end of his life Charles Darwin entertained the greatest affection and reverence for his father, and frequently spoke of him to his own children.

From this brief summary of the family history it is easy to perceive the inherited traits which were combined in the attractive personality of the great scientist. From his early forbears came the keen love of sport and outdoor exercise (to which considerable reference is made in his youth and early manhood); the close application of the philosopher; and the natural aptitude for collecting specimens of all kinds. To his grandfather he was doubtless indebted for his poetic imagination, which, consciously or unconsciously, pervaded his thoughts and writings, saving them from the cold scientific atmosphere which often chills the lay mind. Lastly, the geniality of his father was strongly evidenced by his own love of social intercourse, his courtesy and ready wit, whilst the gentleness of his mother-who unfortunately died when he was 7 years old-left a delicacy of feeling which pervaded his character to the very last.

No such sure mental influences, reaching back through several generations, can be traced in the records of the Wallace family, although what is known reveals the source of the dogged perseverance with which Wallace faced the immense difficulties met with by all early pioneer travellers, of that happy diversity of mental interests which helped to relieve his periods of loneliness and inactivity, and of that quiet determination to pursue to the utmost limit every idea which impressed his mind as containing the germ of a wider and more comprehensive truth than had yet been generally recognised and accepted.

The innate reticence and shyness of manner which were noticeable all through his life covered a largeheartedness even in the most careful observation of facts, and 


\section{Alfred Russel Wallace}

produced a tolerant disposition towards his fellow-men even when he most disagreed with their views or dogmas. He was one of those of whom it may be truly said in hackneyed phrases that he was "born great," whilst destined to have "greatness thrust upon him" in the shape of honours which he received with hesitation.

From his autobiography we gather that his father, though dimly tracing his descent from the famous Wallace of Stirling, was born at Hanworth, in Middlesex, where there appears to have been a small colony of residents bearing the same name but occupying varied social positions, from admiral to hotel-keeper-the grandfather of Alfred Russel Wallace being known as a victualler. Thomas Vere Wallace was the only son of this worthy innkeeper; and, being possessed of somewhat wider ambitions than a country life offered, was articled to a solicitor in London, and eventually became an attorney-at-law. On his father's death he inherited a small private income, and, not being of an energetic disposition, he preferred to live quietly on it instead of continuing his practice. His main interests were somewhat literary and artistic, but without any definite aim ; and this lack of natural energy, mental and physical, reappeared in most of the nine children subsequently born to him, including Alfred Russel, who realised that had it not been for the one definite interest which gradually determined his course in life (an interest demanding steady perseverance and concentrated thought as well as physical enterprise), his career might easily have been much less useful.

It was undoubtedly from his father that he acquired an appreciation of good literature, as they were in the habit of hearing Shakespeare and similar works read aloud round the fireside on winter nights; whilst from his mother came artistic and business-like instincts-several of her relatives 


\section{Early Years}

having been architects of no mean skill, combining with their art sound business qualities which placed them in positions of civic authority and brought them the respect due to men of upright character and good parts.

During the chequered experiences which followed the marriage of Thomas Vere Wallace and Mary Ann Greenell there appears to have been complete mutual affection and understanding. Although Wallace makes but slight reference to his mother's character and habits, one may readily conclude that her disposition and influence were such as to leave an indelible impression for good on the minds of her children, amongst her qualities being a talent for not merely accepting circumstances but in a quiet way making the most of each experience as it came-a talent which we find repeated on many occasions in the life of her son Alfred.

It is a little curious that each of these great scientists should have been born in a house overlooking a wellknown river-the home of the Darwins standing on the banks of the Severn, at Shrewsbury, and that of the Wallaces a stone's throw from the waters of the romantic and beautiful Usk, of Monmouthshire.

With rē̄arkable clearness Dr. Wallace could recall events and scenes back to the time when he was only 4 years of age. His first childish experiment occurred about that time, due to his being greatly impressed by the story of the "Fox and the Pitcher" in Fsop's Fables. Finding a jar standing in the yard outside their house, he promptly proceeded to pour a small quantity of water into it, and then added a handful of small stones. The water not rising to the surface, as it did in the fable, he found a spade and scraped up a mixture of earth and pebbles which he added to the stones already in the jar. The result, however, proving quite unsatisfactory, he gave up the experiment 


\section{Alfred Russel Wallace}

in disgust and refused to believe in the truth of the fable. His restless brain and vivid imagination at this early period is shown by some dreams which he could still recall when 82 years of age; whilst the strong impression left on his mind by certain localities, with all their graphic detail of form and colour, enabled him to enjoy over again many of the simple pleasures that made up his early life in the beautiful grounds of the ancient castle in which he used to play.

The first great event in his life was the journey undertaken by ferry-boat and stage-coach from Usk to Hertford, to which town the family removed when he was 6 years old, and where they remained for the next eight years, until he left school.

The morning after their arrival an incident occurred which left its trace as of a slender golden thread running throughout the fabric of his long life. Alfred, with childlike curiosity about his new surroundings, wandered into the yard behind their house, and presently heard a voice coming from the other side of the low wall, saying, "Hallo! who are you?" and saw a boy about his own age peering over the top. Explanations followed, and soon, by the aid of two water-butts, the small boys found themselves sitting side by side on the top of the wall, holding a long and intimate conversation. Thus began his friendship with George Silk, and by some curious trend of circum. stances the two families became neighbours on several subsequent occasions, ${ }^{1}$ so that the friendship was maintained until in due course the boys separated each to his own way

1 "While at Hertford I lived altogether in five different houses, and in three of these the Silk family lived next door to us, which involved not only each family having to move about the same time, but also that two houses adjoining each other should have been vacant together, and that they should have been of the size required by each, which after the first was not the same, the Silk family being much the larger."-“ My Life," i. 32. 


\section{Early Years}

in life-the one to wander in foreign lands, the other to occupy a responsible position at home.

After spending about a year at private schools, Alfred Wallace was sent with his brother John to Hertford Grammar School. His recollections of these school days are full of interest, especially as contrasted with the school life of to-day. He says: "We went to school even in the winter at seven in the morning, and three days a week remained till five in the afternoon; some artificial light was necessary, and this was effected by the primitive method of every boy bringing his own candle or candleends with any kind of candlestick he liked. An empty ink-bottle was often used, or the candle was even stuck on to the desk with a little of its own grease. So that it enabled us to learn our lessons or do our sums, no one seemed to trouble about how we provided the light."

Though never robust in health, he enjoyed all the usual boyish sports, especially such as appealed to his imagination and love of adventure. Not far from the school a natural cave, formed in a chalky slope and partially concealed by undergrowth, made an excellent resort for "brigands"; and to this hiding-place were brought potatoes and other provisions which could be cooked and eaten in primitive fashion, with an air of secrecy which added to the mystery and attraction of the boyish adventure.

It is curious to note that one destined to become a great traveller and explorer should have found the study of geography "a painful subject." But this was, as he afterwards understood, entirely due to the method of teaching then, and sometimes now, in vogue, which made no appeal whatever to the imagination by creating a mental picture of the peoples and nations, or the varied wonders and beauties of nature which distinguish one 


\section{Alfred Russel Wallace}

country from another. "No interesting facts were ever given, no accounts of the country by travellers were ever read, no good maps ever given us, nothing but the horrid stream of unintelligible place-names to be learnt." The only subjects in which he considered that he gained some valuable grounding at school were Latin, arithmetic, and writing.

This estimate of the value of the grammar-school teaching is echoed in Darwin's own words when describing his school days at precisely the same age at Shrewsbury Grammar School, where, he says, "the school as a means of education to me was simply a blank." It is therefore interesting to notice, side by side, as it were, the occupation which each boy found for himself out of school hours, and which in both instances proved of immense value in their respective careers in later life.

Darwin, even at this early age, found his "taste for natural history, and more especially for collecting," well developed. "I tried," he says, " to make out the names of plants, and collected all sorts of things, shells, seals, franks, coins and minerals. The passion for collecting which leads a man to be a systematic naturalist . . . was very strong in me, and was clearly innate, as none of my sisters or brothers ever had this taste."

He also speaks of himself as having been a very " simple little fellow" by the manner in which he was either himself deceived or tried to deceive others in a harmless way. As an instance of this, he remembered declaring that he could "produce variously coloured polyanthuses and primroses by watering them with certain coloured fluids," though he knew all the time it was untrue. His feeling of tenderness towards all animals and insects is revealed in the fact that he could not remember-except on one occasion-ever taking more than one egg out of a bird's nest; and though a keen 


\section{Early Years}

angler, as soon as he heard that he could kill the worms with salt and water he never afterwards "spitted a living worm, though at the expense, probably, of some loss of success!"

Nothing thwarted young Darwin's intense joy and interest in collecting minerals and insects, and in watching and making notes upon the habits of birds. In addition to this wholesome outdoor hobby, the tedium of school lessons was relieved for him by reading Shakespeare, Byron and Scott-also a copy of "Wonders of the World" which belonged to one of the boys, and to which he always attributed his first desire to travel in remote countries, little thinking how his dreams would be fulfilled.

Whilst Charles Darwin occupied himself with outdoor sport and collecting, with a very moderate amount of reading thrown in at intervals, Wallace, on the contrary, devoured all the books he could get; and fortunately for him, his father having been appointed Librarian to the Hertford Town Library, Alfred had access to all the books that appealed to his mental appetite; and these, especially the historical novels, supplemented the lack of interesting history lessons at school, besides giving him an insight into many kinds of literature suited to his varied tastes and temperament. In addition, however, to the hours spent in reading, he and his brother John found endless delight in turning the loft of an outhouse adjoining their yard into a sort of mechanical factory. Here they contrived, by saving up all their pence (the only pocketmoney that came to them), to make crackers and other simple fireworks, and to turn old keys into toy cannon, besides making a large variety of articles for practical domestic purposes. Thus he cultivated the gift of resourcefulness and self-reliance on which he had so often to depend 


\section{Alfred Russel Wallace}

when far removed from all civilisation during his travels on the Amazon and in the Malay Archipelago.

A somewhat amusing instance of this is found in a letter to his sister, dated June 25th, 1855, at a time when he wanted a really capable man for his companion, in place of the good -natured but incapable boy Charles, whom he had brought with him from London to teach collecting. In reply to some remarks by his sister about a young man who she thought would be suitable, he wrote: "Do not tell me merely that he is 'a very nice young man.' of course he is. . . . I should like to know whether he can live on rice and salt fish for a week on occasion. . . . Can he sleep on a board? . . Can he walk twenty miles a day? Whether he can work, for there is sometimes as hard work in collecting as in anything. Can he saw a piece of wood straight? Ask him to make you anything -a little card box, a wooden peg or bottle-stopper, and see if he makes them neat and square."

In another letter he describes the garden and live stock he had been able to obtain where he was living; and in yet another he gives a long list of his domestic woes and tribulations-which, however, were overcome with the patience inculcated in early life by his hobbies, and also by the fact that the family was always more or less in straitened circumstances, so that the children were taught to make themselves useful in various ways in order to assist their mother in the home.

As he grew from childhood into youth, Alfred Wallace's extreme sensitiveness developed to an almost painful degree. He grew rapidly, and his unusual height made him still more shy when forced to occupy any prominent position amongst boys of his own age. During the latter part of his time at Hertford Grammar School his father was unable to pay the usual fees, and it was agreed that Alfred should act 


\section{Early Years}

as pupil teacher in return for the lessons received. This arrangement, while acceptable on the one hand, caused him actual mental and physical pain on the other, as it increased his consciousness of the disabilities under which he laboured in contrast with most of the other boys of his own age.

At the age of 14 Wallace was taken away from school, and until something could be definitely decided about his future-as up to the present he had no particular bent in any one direction-he was sent to London to live with his brother John, who was then working for a master builder in the vicinity of Tottenham Court Road. This was in January, 1837, and it was during the following summer that he joined his other brother, William, at Barton-onthe-Clay, Bedfordshire, and began land surveying. In the meantime, while in London, he had been brought very closely into contact with the economics and ethics of Robert Owen, the well-known Socialist; and although very young in years he was so deeply impressed with the reasonableness and practical outcome of these theories that, though considerably modified as time went on, they formed the foundation for his own writings on Socialism and allied subjects in after years.

As one of our aims in this section is to suggest an outline of the contrasting influences governing the early lives of Wallace and Darwin, it is interesting to note that at the ages of 14 and 16 respectively, and immediately on leaving school, they came under the first definite mental influence which was to shape their future thought and action. Yet how totally different from Wallace's trials as a pupil teacher was the removal of Darwin from Dr. Butler's school at Shrewsbury because "he was doing no good" there, and his father thought it was "time he settled down to his medical study in Edinburgh," never 


\section{Alfred Russel Wallace}

heeding the fact that his son had already one passion in life, apart from "shooting, dogs, and rat-catching," which stood a very good chance of saving him from becoming the disgrace to the family that his good father feared. So that while Wallace was imbibing his first lessons in Socialism at 14 years of age, Darwin at 16 found himself merely enduring, with a feeling of disgust, Dr. Duncan's lectures, which were "something fearful to remember," on materia medica at eight o'clock on a winter's morning, and, worse still, Dr. Munro's lectures on human anatomy, which were " as dull as he was himself." Yet he always deeply regretted not having been urged to practise dissection, because of the invaluable aid it would have been to him as a naturalist.

By mental instinct, however, Darwin soon found himself studying marine zoology and other branches of natural science. This was in a large measure due to his intimacy with Dr. Grant, who, in a later article on Flustra, made some allusion to a paper read by Darwin before the Linnean Society on a small discovery which he had made by the aid of a "wretched microscope" to the effect that the so-called ova of Flustra were really larvæ and had the power of independent action by means of cilia.

During his second year in Edinburgh he attended Jameson's lectures on geology and zoology, but found them so "incredibly dull" that he determined never to study the science.

Then came the final move which, all unknowingly, was to lead Darwin into the pursuit of a science which up to that time had only been a hobby and not in any sense the serious profession of his life. But again how wide the difference between his change from Edinburgh to Cambridge, and that of Wallace from a month's association with a working-class Socialistic community in London to 


\section{Early Years}

land surveying under the simplest rural conditions prevalent amongst the respectable labouring farmers of Bedfordshire -Darwin to the culture and privileges of a great University with the object of becoming a clergyman, and Wallace taking the first road that offered towards earning a living, with no thought as to the ultimate outcome of this life in the open and the systematic observation of soils and land formation.

But the inherent tendencies of Darwin's nature drew him away from theology to the study of geology, entomology and botany. The ensuing four years at Cambridge were very happy ones. While fortunate in being able to follow his various mental and scientific pursuits with the freedom which a good social and financial position secured for him, he found himself by a natural seriousness of manner, balanced by a cheerful temperament and love of sport, the friend and companion of men many years his seniors and holding positions of authority in the world of science. Amongst these the name of Professor Henslow will always take precedence. "This friendship," says Darwin, "influenced my whole career more than any other." Henslow's extensive knowledge of botany, geology, entomology, chemistry and mineralogy, added to his sincere and attractive personality, well-balanced mind and excellent judgment, formed a strong and effective bias in the direction Darwin was destined to follow.

Apart, however, from the strong personal influence of Henslow, Sedgwick and others with whom he came much in contact, two books which he read at this time aroused his "burning zeal to add the most humble contribution to the noble structure of Natural Science"; these' were Sir J. Herschel's "Introduction to the Study of Natural Philosophy," and Humboldt's " Personal Narrative." Indeed, so fascinated was he by the description given of Teneriffe in the latter that he at once set about a plan whereby he might 


\section{Alfred Russel Wallace}

spend a holiday, with Henslow, in that locality, a holiday which was, indeed, to form part of his famous voyage.

By means of his explorations in the neighbourhood of Cambridge, and one or two visits to North Wales, Darwin's experimental knowledge of geology and allied sciences was considerably increased. In his zeal for collecting beetles he employed a labourer to " scrape the moss off old trees in winter, and place it in a bag, and likewise to collect the rubbish at the bottom of the barges in which reeds were brought from the fens, and thus ... got some very rare species."

During the summer vacation of 1831 , at the personal request of Henslow, he accompanied Professor Sedgwick on a geological tour in North Wales. In order, no doubt, to give him some independent experience, Sedgwick sent Darwin on a line parallel with his own, telling him to bring back specimens of the rocks and to mark the stratification on a map. In later years Darwin was amazed to find how much both of them had failed to observe, "yet these phenomena were so conspicuous that . . . a house burnt down by fire could not tell its story more plainly than did the valley of Cwm Idwal."

This tour was the introduction to a momentous change in his life. On returning to Shrewsbury he found a letter awaiting him which contained the offer of a voyage in H.M.S. Beagle. But owing to several objections raised by Dr. Darwin, he wrote and declined the offer; and if it had not been for the immediate intervention of his uncle, Mr. Josiah Wedgwood (to whose house he went the following day to begin the shooting season), who took quite a different view of the proposition, the "Journal of Researches during the Voyage of H.M.S. Beagle," by Charles Darwin, would never have been written.

At length, however, after much preparation and many 


\section{Early Years}

delays, the Beagle sailed from Plymouth on December 27th, 1831, and five years elapsed before Darwin set foot again on English soil. The period, therefore, in Darwin's life which we find covered by his term at Edinburgh and Cambridge, until at the age of 22 he found himself suddenly launched on an entirely new experience full of adventure and fresh association, was spent by Wallace in a somewhat similar manner in so far as his outward objective in life was more or less distinct from the pursuits which gradually dawned upon his horizon, though they were followed as a "thing apart" and not as an ultimate end.

With Wallace's removal into Bedfordshire an entirely new life opened up before him. His health, never very good, rapidly improved; both brain and eye were trained to practical observations which proved eminently valuable. His descriptions of the people with whom he came in contact during these years of country life reveal the quiet toleration of the faults and foibles of others, not devoid of the keen sense of humour and justice which characterised his lifelong attitude towards his fellow-men.

The many interests of his new life, together with the use of a pocket sextant, prompted him to make various experiments for himself. The only sources from which he could obtain helpful information, however, were some cheap elementary books on mechanics and optics which he procured from the Society for the Diffusion of Useful Knowledge; these he studied and "puzzled over" for several years. "Having no friends of my own age," he wrote, "I occupied myself with various pursuits in which I had begun to take an interest. Having learnt the use of the sextant in surveying, and my brother having a book on Nautical Astronomy, I practised a few of the simpler observations. Among these were determining the meridian 


\section{Alfred Russel Wallace}

by equal altitudes of the sun, and also by the pole-star at its upper or lower culmination; finding the latitude by the meridian altitude of the sun, or of some of the principal stars ; and making a rude sundial by erecting a gnomon towards the pole. For these simple calculations I had Hannay and Dietrichsen's Almanac, a copious publication which gave all the important data in the Nautical Almanac, besides much other interesting matter useful for the astronomical amateur or the ordinary navigator. I also tried to make a telescope by purchasing a lens of about $2 \mathrm{ft}$. focus at an optician's in Swansea, fixing it in a paper tube and using the eye-piece of a small opera-glass. With it $I$ was able to observe the moon and Jupiter's satellites, and some of the larger starclusters; but, of course, very imperfectly. Yet it served to increase my interest in astronomy, and to induce me to study with some care the various methods of construction of the more important astronomical instruments ; and it also led me throughout my life to be deeply interested in the grand onward march of astronomical discovery."

At the same time Wallace became attracted by, and in. terested in, the flowers, shrubs and trees growing in that part of Bedfordshire, and he acquired some elementary knowledge of zoology. "It was," he writes, "while living at Barton that I obtained my first information that there was such a science as geology. . . . My brother, like most landsurveyors, was something of a geologist, and he showed me the fossil oysters of the genus Gryphæa and the Belemnites ... and several other fossils which were abundant in the chalk and gravel around Barton. . . . It was here, too, that during my solitary rambles I first began to feel the influence of nature and to wish to know more of the various flowers, shrubs and trees I daily met with, but of which for the most part I did not even know the English names. At that time

$$
1 \text { " My Life," i. 191-2. }
$$




\section{Early Years}

I hardly realised that there was such a science as systematic botany, that every flower and every meanest and most insignificant weed had been accurately described and classified, and that there was any kind of system or order in the endless variety of plants and animals which I knew existed. This wish to know the names of wild plants, to be able to speak ... about them, had arisen from a chance remark I had overheard about a year before. A lady . . . whom we knew at Hertford, was talking to some friends in the street when I and my father met them ... [and] I heard the lady say, 'We found quite a rarity the other day-the Monotropa; it had not been found here before.' This I pondered over, and wondered what the Monotropa was. All my father could tell me was that it was a rare plant; and I thought how nice it must be to know the names of rare plants when you found them.".

One can picture the tall quiet boy going on these solitary rambles, his eye becoming gradually quickened to perceive new forms in nature, contrasting them one with another, and beginning to ponder over the cause which led to the diverse formation and colouring of leaves apparently of the same family.

It was in 1841, four years later, that he heard of, and at once procured, a book published at a shilling by the S.P.C.K. (the title of which he could not recall in after years), to which he owed his first scientific glimmerings of the vast study of botany. The next step was to procure, at much self-sacrifice, Lindley's " Elements of Botany," published at half a guinea, which to his immense disappointment he found of very little use, as it did not deal with British plants! His disappointment was lessened, however, by the loan from a Mr. Hayward of Loudon's " Encyclopedia of Plants," and it was with the help of these two books that he made his first classifica-

1 "My Life," i. 108-111. 


\section{Alfred Russel Wallace}

tion of the specimens which he had collected and carefully kept during the few preceding years.

"It must be remembered," he says in "My Life," "that my ignorance of plants at this time was extreme. I knew the wild rose, bramble, hawthorn, buttercup, poppy, daisy and foxglove, and a very few others equally common. . . . I knew nothing whatever as to genera and species, nor of the large number of distinct forms related to each and grouped into natural orders. My delight, therefore, was great when I was . . . able to identify the charming little eyebright, the strange-looking cow-wheat and louse-wort, the handsome mullein and the pretty creeping toad-flax, and to find that all of them, as well as the lordly foxglove, formed parts of one great natural order, and that under all their superficial diversity of form was a similarity of structure which, when once clearly understood, enabled me to locate each fresh species with greater ease." This, however, was not sufficient, and the last step was to form a herbarium.

"I soon found," he wrote, "that by merely identifying the plants I found in my walks I lost much time in gathering the same species several times, and even then not being always quite sure that I had found the same plant before. I therefore began to form a herbarium, collecting good specimens and drying them carefully between drying papers and a couple of boards weighted with books or stones. . . . I first named the species as nearly as I could do so, and then laid them out to be pressed and dried. At such times," he continues-and I have quoted the passage for the sake of this revealing confession-"I experienced the joy which every discovery of a new form of life gives to the lover of nature, almost equal to those raptures which $I$ afterwards felt at every capture of new butterflies on the Amazon, or at the constant stream of new species of birds, beetles 


\section{Early Years}

and butterflies in Borneo, the Moluccas, and the Aru Islands." 1

Anything in the shape of gardening papers and catalogues which came in his way was eagerly read, and to this source he owed his first interest in the fascinating orchid.

"A catalogue published by a great nurseryman in Bristol . . contained a number of tropical orchids, of whose wonderful variety and beauty I had obtained some idea from the woodcuts in Loudon's 'Encyclopedia.' The first epiphytal orchid I ever saw was at a flower show in Swansea ... which caused in me a thrill of enjoyment which no other plant in the show produced. My interest in this wonderful order of plants was further enhanced by reading in the Gardener's Chronicle an article by Dr. Lindley on one of the London flower shows, where there was a good display of orchids, in which . . . he added, ' and Dendrobium Devonianum, too delicate and beautiful for a flower of earth.' This and other references ... gave them, in my mind, a weird and mysterious charm ... which, I believe, had its share in producing that longing for the tropics which a few years later was satisfied in the equatorial forests of the Amazon." 2

For a brief period, when there was a lull in the surveying business and his prospects of continuing in this profession looked uncertain, he tried watchmaking, and would probably - though not by choice-have been apprenticed to it but for an unexpected circumstance which caused his master to give up his business. Alfred gladly, when the occasion offered, returned to his outdoor life, which had

1 Darwin makes a similar comment: " I was very successful in collecting, and invented two new methods ... and thus $I$ got some very rare species. No poet ever felt more delighted at seeing his first poem published than I did at seeing, in Stephens' 'Illustrations of British Insects,' the magic words, 'captured by C. Darwin, Esq.' "-Darwin's Autobiography, in the one-volume “Life," p, 20.

2 “My Life," i. 194-5. 


\section{Alfred Russel Wallace}

begun to make the strongest appeal to him, stronger, perhaps, than he was really aware.

Early in 1844 another break occurred, due to the sudden falling off of land surveying as a profitable business. His brother could no longer afford to keep him as assistant, finding it indeed difficult to obtain sufficient employment for himself. As Wallace knew no other trade or profession, the only course which occurred to his mind as possible by which to earn a living was to get a post as school teacher.

After one or two rather amusing experiences, he eventually found himself in very congenial surroundings under the Rev. Abraham Hill, headmaster of the Collegiate School at Leicester. Here he stayed for a little more than a year, during which time-in addition to his school work and a considerable amount of hard reading on subjects to which he had not hitherto been able to devote himself-he was led to become greatly interested in phrenology and mesmerism, and before long found himself something of an expert in giving mesmeric demonstrations before small audiences. Phrenology, he believed, proved of much value in determining his own characteristics, good and bad, and in guiding him to a wise use of the faculties which made for his ultimate success; while his introduction to mesmerism had not a little to do with his becoming interested and finally convinced of the part played by spiritualistic forces and agencies in human life.

The most important event, however, during this year at Leicester was his meeting with H. W. Bates, through whom he was introduced to the absorbing study of beetles and butterflies, the link which culminated in their mutual exploration of the Amazon. It is curious that Wallace retained no distinct recollection of how or when he met Bates for the first time, but thought that "he heard 


\section{Early Years}

him mentioned as an enthusiastic entomologist and met him at the Library." Bates was at this time employed by his father, who was a hosiery manufacturer, and he could therefore only devote his spare time to collecting beetles in the surrounding neighbourhood. The friendship brought new interests into both lives, and though Wallace was obliged a few months later to leave Leicester and return to his old work of surveying (owing to the sudden death of his brother William, whose business affairs were left in an unsatisfactory condition and needed personal attention), he no longer found in it the satisfaction he had previously experienced, and his letters to Bates expressed the desire to strike out on some new line, one which would satisfy his craving for a definite pursuit in the direction of natural science.

Somewhere about the autumn of 1847 , Bates paid a visit to Wallace at Neath, and the plan to go to the Amazon which had been slowly forming itself at length took shape, due to the perusal of a little book entitled "A Voyage up the River Amazon," by W. H. Edwards. Further investigations showed that this would be particularly advantageous, as the district had only been explored by the German zoologist, von Spix, and the botanist von Martins, in 1817-20, and subsequently by Count de Castelnau.

During this interval we find, in a letter to Bates, the following allusion to Darwin, which is the first record of Wallace's high estimate of the man with whom his own name was to be dramatically associated ten years later. "I first," he says, " read Darwin's Journal three or four years ago, and have lately re-réad it. As the journal of a scientific traveller it is second only to Humboldt's Narrative; as a work of general interest, perhaps superior to it. $\mathrm{He}$ is an ardent admirer and most able supporter of $\mathbf{M r}$. Lyell's views. His style of writing I very much admire, so 


\section{Alfred Russel Wallace}

free from all labour, or egotism, yet so full of interest and original thought."

The early part of 1848 was occupied in making arrangements with Mr. Samuel Stevens, of King Street, Covent Garden, to act as their agent in disposing of a duplicate collection of specimens which they proposed sending home; by this means paying their expenses during the time they were away, any surplus being invested against their return. This and other matters being satisfactorily settled, they eventually sailed from Liverpool on April 20th in a barque of 192 tons, said to be "a very fast sailer," which proved to be correct. On arriving at Para about a month later, they immediately set about finding a house, learning something of the language, the habits of the people amongst whom they had come to live, and making short excursions into the forest before starting on longer and more trying explorations up country.

Wallace's previous vivid imaginings of what life in the tropics would mean, so far as the surpassing beauty of nature was concerned, were not immediately fulfilled. As a starting-point, however, Para had many advantages. Besides the pleasant climate, the country for some hundreds of miles was found to be nearly level at an elevation of about 30 or $40 \mathrm{ft}$. above the river; the first distinct rise occurring some 150 miles up the river Tocantins, south-west of Para; the whole district was intersected by streams, with cross channels connecting them, access by this means being comparatively easy to villages and estates lying farther inland.

Before making an extensive excursion into the interior, he spent some time on the larger islands at the mouth of

1 There is no record in his autobiography as to the exact date when he first became acquainted with Lyell's work, though several times reference is made to it. 


\section{Early Years}

the Amazon, on one of which he immediately noticed the scarcity of trees, while "the abundance of every kind of animal life crowded into a small space was here very striking, compared with the sparse manner in which it is scattered in the virgin forests. It seems to force us to the conclusion that the luxuriance of tropical vegetation is not favourable to the production of animal life. The plains are always more thickly peopled than the forest; and a temperate zone, as has been pointed out by $\mathrm{Mr}$. Darwin, seems better adapted to the support of large land animals than the tropics."

We have already referred to the fact that at the very early age of 14 Wallace had imbibed his first ideas of Socialism, or how the "commonwealth" of a people or nation was the outcome of cause and effect, largely due to the form of government, political economy and progressive commerce best suited to any individual State or country. The seed took deep root, and during the years spent for the most part amongst an agricultural people in England and Wales his interest in these questions had been quickened by observation and intelligent inquiry. It is no wonder, therefore, that during the whole of his travels we find many intimate references to such matters regarding the locality in which he happened to find himself, but which can only be noticed in a very casual manner in this section. For instance, he soon discovered that the climate and soil round Para conduced to the cultivation of almost every kind of food, such as cocoa, coffee, sugar, farinha (the universal bread of the country) from the mandioca plant, with vegetables and fruits in inexhaustible variety; while the articles of export included india-rubber, Brazil nuts, and piassaba (the coarse, stiff fibre of a palm, used for making brooms for street sweeping), as well as sarsaparilla, balsam-capivi, and a few other drugs. 


\section{Alfred Russel Wallace}

The utter lack of initiative, or even ordinary interest, in making the most of the opportunities lying at hand, struck him again and again as he went from place to place and was entertained hospitably by hosts of various nationalities; until at times the impression is conveyed that apart from his initial interest as a naturalist, a longing seized him to arouse those who were primarily responsible for these conditions out of the apathy into which they had fallen, and to make them realise the larger pleasure which life offers to those who recognise the opportunities at hand, not only for their own advancement but also for the benefit of those placed under their control. All of which we find happily illustrated during his visit to Sarawak, in the Malay Archipelago.

The whole of these four years was crowded with valuable experiences of one sort and another. Some of the most toilsome journeys proved only a disappointment, while others brought success beyond his most sanguine dreams. At the end of two years it was agreed between himself and Bates that they should separate, Wallace doing the northern parts and tributaries of the Amazon, and Bates the main stream, which, from the fork of the Rio Negro, is called the Upper Amazon, or the Solimoes. By this arrangement they were able to cover more ground, besides devoting themselves to the special goal of research on which each was bent.

In the meantime, Wallace's younger brother, Herbert, had come out to join him, and for some time their journeys were made conjointly; but finding that his brother was not temperamentally fitted to become a naturalist, it was decided that he should return to England. Accordingly, they parted at Barra when Wallace started on his long journey up the Rio Negro, the duration of which was uncertain; and it was not until many months after the sad event that he heard the distressing news that Herbert had died of yellow fever on the eve of his departure from Para for home. Fortunately, 


\section{Early Years}

Bates was in Para at the time, and did what he could for the boy until stricken down himself with the same sickness, from which, however, his stronger constitution enabled him to recover.

Perhaps the most eventful and memorable journey during this period was the exploration of the Uaupés River, of which Wallace wrote nearly sixty years later : "So far as I have heard, no English traveller has to this day ascended the Uaupés River so far as I did, and no collector has stayed at any time at Javita, or has even passed through it."

From a communication received from the Royal Geographical Society it appears that the first complete survey of this river (a compass traverse supplemented by astronomical observations) was made (1907-8) by Dr. Hamilton Rice, starting from the side of Colombia, and tracing the whole course of the river from a point near the source of its head-stream. The result showed that the general course of the lower river was much as represented by Wallace, though considerable corrections were necessary both in latitude and longitude. "I am assured by authorities on the Rio Negro region," writes Dr. Scott Keltie to Mr. W. G. Wallace, under date May 21, 1915, "that your father's work still holds good."

In May, 1852, Wallace returned to Para, and sailed for England the following July. The ship took fire at sea, and all his treasures (not previously sent to England) were unhappily lost. Ten days and nights were spent in an open boat before another vessel picked them up, and in describing this terrible experience he says: "When the danger appeared past I began to feel the greatness of my loss. With what pleasure had I looked upon every rare and curious insect $I$ had added to my collection! How many times, when almost overcome by the ague, had I crawled into the forest and been rewarded by some 


\section{Alfred Russel Wallace}

unknown and beautiful species! How many places, which no European foot but my own had trodden, would have been recalled to my memory by the rare birds and insects they had furnished to my collection! How many weary days and weeks had I passed, upheld only by the fond hope of bringing home many new and beautiful forms from these wild regions... which would prove that I had not wasted the advantage I had enjoyed, and would give me occupation and amusement for many years to come! And now ... I had not one specimen to illustrate the unknown lands I had trod, or to call back the recollection of the wild scenes I had beheld! But such regrets were vain ... and I tried to occupy myself with the state of things which actually existed."

On reaching London, Wallace took a house in Upper Albany Street, where his mother and his married sister (Mrs. Sims), with her husband, a photographer, came to live with him. The next eighteen months were fully occupied with sorting and arranging such collections as had previously reached England; writing his book of travels up the Amazon and Rio Negro (published in the autumn of 1853), and a little book on the palm trees based on a number of fine pencil sketches he had preserved in a tin box, the only thing saved from the wreck.

In summing up the most vivid impressions left on his mind, apart from purely scientific results, after his four years in South America, he wrote that the feature which he could never think of without delight was "the wonderful variety and exquisite beauty of the butterflies and birds . . . ever new and beautiful, strange and even mysterious," so that he could "hardly recall them without a thrill of admiration and wonder." But "the most unexpected sensation of surprise and delight was my first meeting and 


\section{Early Years}

living with man in a state of nature-with absolute uncontaminated savages! . . . and the surprise of it was that $I$ did not expect to be at all so surprised. . . These true wild Indians of the Uaupés . . . had nothing that we call clothes; they had peculiar ornaments, tribal marks, etc.; they all carried tools or weapons of their own manufacture. . . But more than all, their whole aspect and manner was different-they were all going about their own work or pleasure, which had nothing to do with white men or their ways; they walked with the free step of the independent forest-dweller, and, except the few that were known to my companion, paid no attention whatever to us, mere strangers of an alien race! In every detail they were original and self-sustaining as are the wild animals of the forest, absolutely independent of civilisation. . . . I could not have believed that there would have been so much difference in the aspect of the same people in their native state and when living under European supervision. The true denizen of the Amazonian forest, like the forest itself, is unique and not to be forgotten."

The foregoing "impressions" recall forcibly those expressed by Darwin in similar terms at the close of his "Journal": "Delight . . . is a weak term to express the feelings of a naturalist who, for the first time, has wandered by himself in a Brazilian forest. The elegance of the grasses, the novelty of the parasitical plants, the beauty of the flowers, the glossy green of the foliage ... the general luxuriance of the vegetation, filled me with admiration. A paradoxical mixture of sound and silence pervades the shady parts of the wood ... yet within the recesses . . . a universal silence appears to reign ... . such a day as this brings with it a deeper pleasure than he (a naturalist) can ever hope to experience again." And in 1 "Voyage of the Beagle," pp. 11-12. 


\section{Alfred Russel Wallace}

another place: "Among the scenes which are deeply impressed on my mind, none can exceed in sublimity the primeval forests undefaced by the hand of man;... temples filled with the various productions of the God of Nature ; . . no one can stand in these solitudes unmoved, and not feel that there is more in man than the mere breath of his body."

In complete contrast to the forest, the bare, treeless, and uninhabited plains of Patagonia "frequently crossed before" Darwin's eyes. Why, he could not understand, except that, being so "boundless," they left "free scope for the imagination."

As these travels, ${ }^{2}$ undertaken at comparatively the same age, represent the foundation upon which their scientific work and theories were based during the long years which followed, a glance at the conditions governing the separate expeditions-both mental and physical-may be of some value. The most obvious difference lies, perhaps, in the fact that Darwin was free from the thought of having to "pay his way" by the immediate result of his efforts, and likewise from all care and anxiety regarding domestic concerns; the latter being provided for him when on board the Beagle, or arranged by those who accompanied him on his travels overland and by river. The elimination of these minor cares tended to leave his mind free and open to absorb and speculate at comparative leisure upon all the strange phenomena which presented themselves throughout the long voyage.

A further point of interest in determining the ultimate gain or loss lies in the fact that Darwin's private excursions had to be somewhat subservient to the movements of

2 "Voyage of the Beagle," p. 534.

2 It is interesting to note that the careers of Sir Joseph Hooker, Charles Darwin, H. W. Bates, Alfred Russcl Wallace and T. H. Huxley were all determined by voyages or journeys of exploration. 


\section{Early Years}

the Beagle under the command of Captain Fitz-Roy. This, in all probability, was beneficial to one of his temperament - unaccustomed to be greatly restricted by outward circum. stances or conditions, though never flagrantly (or, perhaps, consciously) going against them. The same applies in a measure to Wallace, who, on more than one occasion, confessed his tendency to a feeling of semi-idleness and dislike to any form of enforced physical exertion; but as every detail, involving constant forethought and arrangement, as well as the execution, devolved upon himself, the latent powers of methodical perseverance, which never failed him, no matter what difficulties barred his way, were called forth. Darwin's estimate of the "habit of mind" forced upon himself during this period may not inaptly be applied to both men: "Everything about which $I$ thought or read was made to bear directly on what I had seen, or was likely to see; and this habit of mind was continued during the five years of the voyage. I feel sure that it was this train. ing which enabled me to do whatever I have done in science."

It may be further assumed that Darwin was better equipped mentally-from a scientific point of view-owing to his personal intercourse with eminent scientific men previous to his assuming this responsible position. Wallace, on the contrary, had practically little beyond bookknowledge and such experience as he had been able to gain by solitary wanderings in the localities in which he had, by circumstances, been forced to reside. His plan of operations must, therefore, have been largely modified and adapted as time went on, and as his finances allowed. To both, therefore, credit is due for the adaptability evinced under conditions not always congenial or conducive to the pursuits they had undertaken.

Although the fact is not definitely stated by Wallace, it may readily be inferred that the idea of making this the 


\section{Alfred Russel Wallace}

starting-point of a new life was clearly in his mind; while Darwin simply accepted the opportunity when it came, and was only brought to a consciousness of its full meaning and bearing on his future career whilst studying the geological aspect of Santiago when "the line of white rock revealed a new and important fact," namely, that there had been afterwards subsidence round the craters, which had since been in action and had poured forth lava. "It then," he says, "first dawned on me that I might perhaps write a book on the geology of the various countries visited, and this made me thrill with delight. That was a memorable hour to me; and how distinctly I can call to mind the low cliff of lava, beneath which I rested, with the sun glaring hot, a few strange desert plants growing near, and with living corals in the tidal pools at my feet!"

Another point of comparison lies in the fact that at no time did the study of man or human nature, from the metaphysical and psychological point of view, appeal to Darwin as it did to Wallace; and this being so, the similarity between the impression made on them individually by their first contact with primitive human beings is of some interest.

Wallace's words have already been quoted; here are Darwin's: "Nothing is more certain to create astonishment than the first sight in his native haunt of a barbarian, of man in his lowest and most savage state. One asks: 'Could our progenitors have been men like these -men whose very signs and expressions are less intelligible to us than those of the domesticated animals; men who do not possess the instinct of those animals, nor yet appear to boast of human reason, or at least of arts consequent on that reason?' I do not believe it is possible to describe or paint the difference between a savage and 1 "Life of Charles Darwin" (one-volume Edit.), p. 29. 


\section{Early Years}

civilised man. It is the difference between a wild and tame animal."1

The last words suggest the seed-thought eventually to be enlarged in "The Descent of Man," and there is also perhaps a subtle suggestion of the points in which Wallace differed from Darwin when the time came for them to discuss this important section of the theory of Evolution. It needed, however, the further eight years spent by Wallace in the Malay Archipelago to bring about a much wider knowledge of nature-science before he was prepared in any way to assume the position of exponent of theories not seriously thought of previously in the scientific world.

In the autumn of 1853, on the completion of his "Travels on the Amazon and Rio Negro," Wallace paid his first visit to Switzerland, on a walking tour in company with his friend George Silk. On his return, and during the winter months, he was constant in his attendance at the meetings of the Entomological and Zoological Societies. It was at one of these evening gatherings that he first met Huxley, and he also had a vague recollection of once meeting and speaking to Darwin at the British Museum. Had it not been for his extreme shyness of disposition, and (according to his own estimation) "lack of conversational powers," he would doubtless have become far more widely known, and have enjoyed the friendship of not a few of the eminent men who shared his interests, during this interval before starting on his journey to Singapore.

It was due to his close study of the Insect and Bird Departments of the British Museum that he decided on Singapore as a new starting-point for his natural history collections. As the region was generally healthy, and no 1 " Voyage of the Beagle," p. 535. 


\section{Alfred Russel Wallace}

part of it (with the exception of the Island of Java) had been explored, it offered unlimited attractions for his special work. But as the journey out would be an expensive one, he was advised to lay his plans before Sir Roderick Murchison, then President of the Royal Geographical Society, and it was through his kindly interest and personal application to the Government that a passage was provided in one of the $P$. and $O$. boats going to Singapore. He left early in 1854. Arrived at Singapore, an entirely new world opened up before him. New peoples and customs thronged on all hands, a medley of nationalities such as can only be seen in the East, where, even to-day, and though forming part of one large community, each section preserves its native dress, customs and religious habits. After spending some time at Singapore he moved from place to place, but finally decided upon making Ternate his head-quarters, as he discovered a comfortable bungalow, not too large, and adaptable in every way as a place in which to collect and prepare his specimens between the many excursions to other parts of the Archipelago. The name is now indelibly associated with that particular visit which ended after a trying journey in an attack of intermittent fever and general prostration, during which he first conceived the idea which has made Ternate famous in the history of natural science.

One or two points in the following letters recall certain contrasts similar to those already drawn between Darwin's impression of places and people and those made on the mind of Wallace by practically the same conditions. A typical instance is found in their estimate of the life and work of the missionaries whom they met and from whom they received the warmest hospitality. Their experience included both Protestant and Roman Catholic, and from Darwin's account the former appeared to him to have the more 


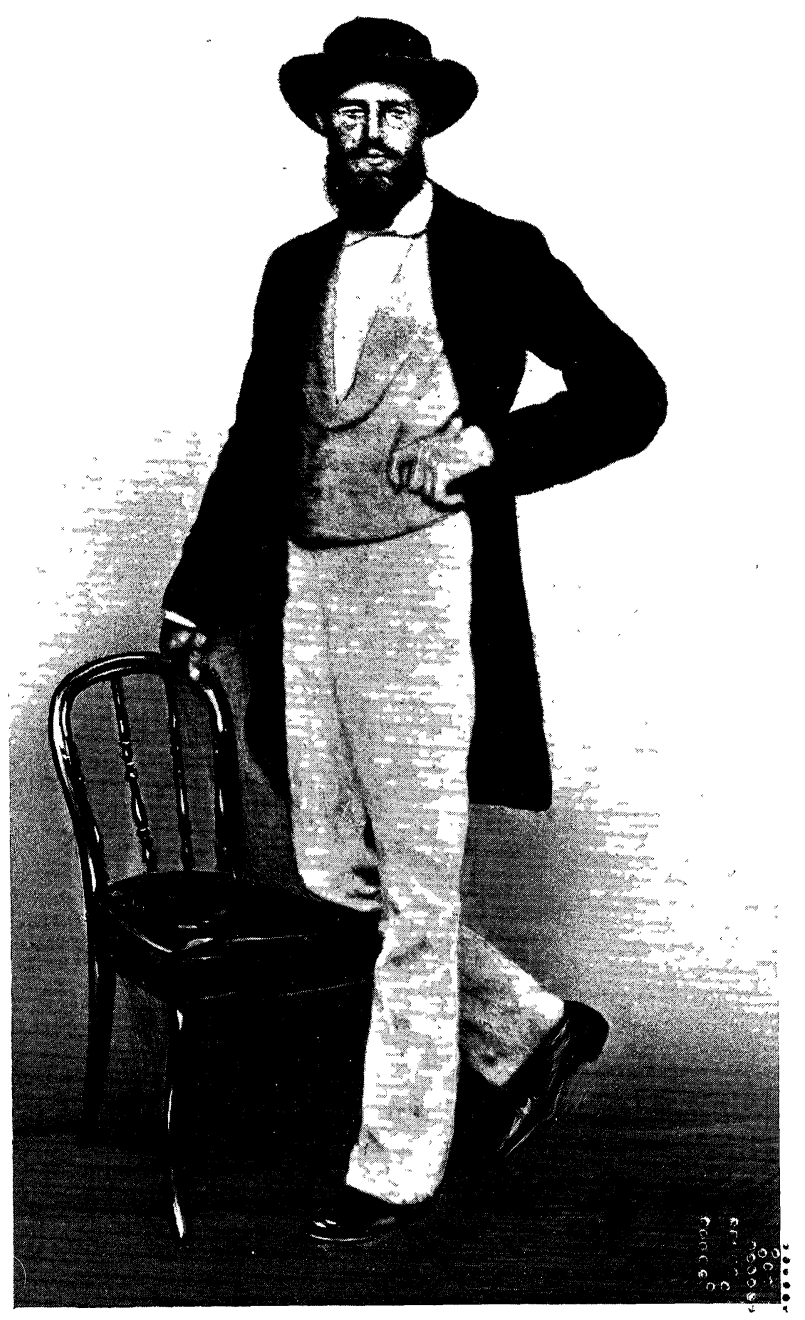

A. R. WALLACE (Singapore, 1862) 
$\vdots \vdots \vdots \vdots \vdots$ 


\section{Early Years}

civilising effect on the people, not only from a religious but also from the economic and industrial points of view.

In the "Journal" (p. 419) we find a detailed account of a visit to the missionary settlement at Waimate, New Zealand. After describing the familiar English appearance of the whole surroundings, he adds: "All this is very surprising when it is considered that five years ago nothing but the fern flourished here. Moreover, native workmanship, taught by these missionaries, has effected this change-the lesson of the missionary is the enchanter's wand. The house had been built, the windows framed, the fields ploughed, and even the trees grafted, by the New Zealander. When I looked at the whole scene it was admirable. It was not that England was brought vividly before my mind ; . . . nor was it the triumphant feeling at seeing what Englishmen could effect; but rather the high hopes thus inspired for the future progress of this fine island."

No such feeling was inspired by the conditions surrounding the Roman Catholic missionaries whom he met from time to time. In an earlier part of the "Journal" he records an evening spent with one living in a lonely place in South America who, "coming from Santiago, had contrived to surround himself with some few comforts. Being a man of some little education, he bitterly complained of the total want of society. With no particular zeal for religion, no business or pursuit, how completely must this man's life be wasted."

In complete opposition to these views, passages occur in the following letters which show that Wallace thought more highly of the Roman Catholic than of the Protestant missionaries. In one place, speaking of the former, he says : "Most are Frenchmen . . . well-educated men who give up their lives for the good of the people they live 


\section{Alfred Russel Wallace}

among. I think Catholics and Protestants are equally wrong, but as missionaries I think Catholics are the best, and I would gladly see none others rather than have, as in New Zealand, sects of native Dissenters more rancorous against each other than in England. The unity of the Catholics is their strength, and an unmarried clergy can do as missionaries what married men never can under. take."

As a sidelight on these contradictory estimates of the same work, it should be borne in mind that Darwin had but recently given up the idea of becoming a clergyman, and doubtless retained some of the instinctive regard for sincere Christian Protestantism (whether represented by the Church of England or by Nonconformists), while Wallace had long since relinquished all doctrinal ideas on religion and all belief in the beneficial effect produced by forms of worship on the individual.

Among the regions Wallace visited was Sarawak. Of one of his sojourns here some interesting reminiscences have been sent to me by Mr. L. V. Helmes. He says :

It was in 1854 that Wallace came to Sarawak. I was there then, sent by a private firm, which later became the Borneo Company, to open up, by mining, manufacture and trade, the resources of the country, and amongst these enterprises was coal-mining on the west. Wallace came in search of new specimens of animal and especially insect life. The clearing of ancient forests at these mines offered a naturalist great opportunities, and I gave Wallace an introduction to our engineer in charge there. His collections of beetles and butterflies there were phenomenal ; but the district was also the special home of the great ape, the orang-utan, or meias, as the natives called them, of which he obtained so many valuable specimens. Many notes must at that time have passed between us, for I took much interest in his work. We had put up a temporary hut for him at the mines, and 


\section{Early Years}

on my occasional visits there I saw him and his young assistant, Charles Allen, at work, admired his beautiful collections, and gave my help in forwarding them.

But it was mainly in social intercourse that we met, when Wallace, in intervals of his labours, came to $\mathrm{Ku}$ ching, and was the Rajah's guest. Then occurred those interesting discussions at social gatherings to which he refers in a letter to me in 1909, when he wrote: "I was pleased to receive your letter, with reminiscences of old times. I often recall those pleasant evenings with Rajah Brooke and our little circle, but since the old Rajah's death I have not met any of the party."

Wallace was in Sarawak at the happy period in the country's history. It was beginning to emerge from barbarism. The Borneo Company was just formed, and the seed of the country's future prosperity was sown. Wallace, therefore, found us all sanguine and cheerful; yet we were on the brink of a disaster which brought many sorrows in its train. But the misfortunes of the Chinese revolt had not yet cast their shadows before them. The Rajah's white guests round his hospitable table; the Malay chiefs and office-holders, who made evening calls from curiosity or to pay their respects; Dyaks squatting in dusky groups in corners of the hall, with petitions to make or advice to seek from their white ruler-such would be the gathering of which Wallace would form a part. No suspicion or foreboding would trouble the company; yet within a few months that hall would be given to the flames of an enemy's torch, and the Rajah himself and many of those who formed that company would be fugitives in the jungle. ...

The Malay Archipelago, in the unregenerated days when Wallace roamed the forests, and sailed the Straits in native boats and canoes, was full of danger to wanderers of the white race. Anarchy prevailed in many parts; usurping nobles enslaved the people in their houses; and piratical fleets scoured the sea, capturing and enslaving yearly thousands of peaceful traders, women and children. The writer was himself in 1862 besieged in a Bornean river by 


\section{Alfred Russel Wallace}

a pirate fleet, which was eventually destroyed by a Sarawak Government steamer with the following result of the fight : 190 pirates and 140 captives were killed or drowned, and 250 of the latter were liberated and sent to their homes; showing how formidable these pirates were. But Wallace, absorbed in his scientific pursuits, minded not these dangers, nor the hardships of any kind which a roving life in untrodden jungles and feverish swamps brings.

When Wallace left Sarawak after his fifteen months' residence in the country, he left his young assistant, Charles Allen, there. He entered my service, and remained some time after the formation of the Borneo Company. Later, he again joined Wallace, and then went to New Guinea, doing valuable collecting and exploring work. He finally settled in Singapore, where I met him in 1899. He had married and was doing well; but died not long after my interview with him. He had come to the East with Wallace as a lad of 16 , and had been his faithful companion and assistant during years of arduous work.-L. V. H.

The eight years spent by Wallace in this almost un. known part of the world were times of strenuous mental and physical exertion, resulting in the gathering together of an enormous amount of matter for future scientific investigation, but counterbalanced unfortunately by more or less continuous ill-health-which at times made the effort of clear reasoning and close application to scientific pursuits extremely difficult.

An indication of the unwearying application with which he went about his task is seen in the fact that during this period he collected 125,660 specimens of natural history, travelled about 14,000 miles within the Archipelago, and made sixty or seventy journeys, "each involving some preparation and loss of time," so that " not more than six years were really occupied in collect. ing." 


\section{Early Years}

A faint idea of this long and solitary sojourn in lonely places is given in a letter to his old friend Bates, dated December 24th, 1860, in which he says: "Many thanks for your long and interesting letter. I have myself suffered much in the same way as you describe, and I think more severely. The kind of tadium vite you mention I also occasionally experience here. I impute it to a too monotonous existence." And again when he begs his friend to write, as he is " half froze for news."

As already stated, Wallace, at no time during these wanderings, had any escort or protection, having to rely entirely upon his own tact and patience, combined with firmness, in his dealings with the natives. On one occasion he was taken ill, and had to remain six weeks with none but native Papuans around him, and he became so attached to them that when saying good-bye it was with the full intention of returning amongst them at a later period. In another place he speaks of sleeping under cover of an open palm-leaf hut as calmly as under the protection of the Metropolitan Police!

Up to that time, also, he was the only Englishman who had actually seen the beautiful "birds of paradise in their native forests," this success being achieved after "five voyages to different parts of the district they inhabit, each occupying in its preparation and execution the larger part of a year." And then only five species out of a possible fourteen were procured. His enthusiasm as a naturalist and collector knew no bounds, butterflies especially calling into play all his feelings of joy and satisfaction. Describing his first sight of the Ornithoptera crosus, he says that the blood rushed to his head and he felt much more like fainting than he had done when in apprehension of immediate death; a similar sensation being experienced when he came across another large bird-winged butterfly, Ornith- 


\section{Alfred Russel Wallace}

optera poseidon. "It is one thing," he says, "to see such beauty in a cabinet, and quite another to feel it struggling between one's fingers, and to gaze upon its fresh and living beauty, a bright-green gem shining out amid the silent gloom of a dark and tangled forest. The village of Dobbo held that evening at least one contented man."

These thrills of joy may be considered as some compensation for such experiences as those contained in his graphic account of a single journey in a "prau," or native boat. "My first crew," he wrote, "ran away; two men were lost for a month on a desert island; we were ten times aground on coral reefs; we lost four anchors; our sails were devoured by rats; the small boat was lost astern; we were thirty-eight days on the voyage home which should have taken twelve; we were many times short of food and water; we had no compass-lamp owing to there not being a drop of oil in Waigiou when we left; and to crown it all, during the whole of our voyage, occupying in all seventy-eight days (all in what was supposed to be the favourable season), we had not one single day of fair wind."

The scientific discoveries arising out of these eight years of laborious work and physical hardship were first-with the exception of the memorable Essay on Natural Selection-included in his books on the Malay Archipelago, the Geographical Distribution of Animals, Island Life, and Australasia, besides a number of papers contributed to various scientific journals.

A bare catalogue of the places visited and explored includes Sumatra, Java, Borneo, Celebes, the Moluccas, Timor, New Guinea, the Aru and Ké Islands. Comparing this list with that given by Darwin at the close of the "Journal," we find that though in some respects the 


\section{Early Years}

ground covered by the two men was similar, it never actually overlapped. The countries and islands visited by the Beagle came in the following order: Cape de Verde Islands, St. Paul's Rocks, Fernando Noronha, South America (including the Galapagos Archipelago, the Falkland Isles, and Tierra del Fuego), Tahiti, New Zealand, Australia, Tasmania, Keeling Island, Maldive coral atolls, Mauritius, St. Helena, Ascension. Brazil was revisited for a short time, and the Beagle touched at the Cape de Verde Islands and the Azores on the homeward voyage.

The very nature of this voyage did not permit Darwin to give unlimited time to the study of any particular spot or locality; but his accurate observation of every detail, together with his carefully kept journal, afforded ample scope and foundation for future contemplation. To Wallace, the outstanding result may be summed up in the fact that he discovered that the Malay Archipelago is divided into a western group of islands, which in their zoological affinities are Asiatic, and an eastern, which are Australian. The Oriental Borneo and Bali are respectively divided from the Australian Celebes and Lombok by a narrow belt of sea known as "Wallace's line," on the opposite side of which the indigenous mammalia are as widely divergent as in any two parts of the world.

To both men Darwin's estimate of the influence of travel may aptly apply in the sense that from a geographical point of view "the map of the world ceases to be a blank . . . each part assumes its proper dimensions," continents are no longer considered islands, nor islands as mere specks.

Wallace's homeward journey was not so eventful as the previous one had been, except for the unsuccessful efforts to bring back several species of live birds, which, with the exception of his birds of paradise, died on the way. On 


\section{Alfred Russel Wallace}

reaching London in the spring of 1862, he again made his home with his married sister, Mrs. Sims (who was living in Westbourne Grove). In a large empty room at the top of the house he found himself surrounded with packing. cases which he had not seen for five or six years, and which, together with his recent collections, absorbed his time and interest for the first few weeks. Later, he settled down to his literary work, and, with the exception of one or two visits to the Continent and America, spent the remainder of his life in England-a life full of activity, the results of which still permeate scientific research. 


\section{PART I (Continued)}

\section{Early Letters}

[1854-62]

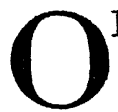

$F$ the few letters which have been preserved relating to this period, a number have already been published in "My Life," and need not be reprinted here. But in some cases portions of these letters have been given because they bring out aspects of Wallace's character which are not revealed elsewhere. The various omissions which have been made in other letters refer either to unimportant personal matters or to technical scientific details. The first of the letters was written during Wallace's voyage to the Malay Archipelago.

\section{To G. SILE}

Steamer "Bengal," Red Sea. March 26, [1854].

My dear George,- . . . Of all the eventful days of my life my first in Alexandria was the most striking. Imagine my feelings when, coming out of the hotel (whither I had been conveyed in an omnibus) for the purpose of taking a quiet stroll through the city, I found myself in the midst of a vast crowd of donkeys and their drivers, all thoroughly determined to appropriate my person to their own use and interest, without in the least consulting my inclinations. In vain with rapid strides and waving arms I endeavoured to clear a way and move forward; arms and legs were seized upon, and even the Christian coat-tails were not sacred from the profane Mahometans. One would hold together two donkeys 


\section{Alfred Russel Wallace}

by their tails while $I$ was struggling between them, and another, forcing together their heads, would thus hope to compel me to mount upon one or both of them; and one fellow more impudent than the rest $I$ laid flat upon the ground, and sending the donkey staggering after him, I escaped a moment midst hideous yells and most unearthly cries. I now beckoned to a fellow more sensible-looking than the rest, and told him that I wished to walk and would take him for a guide, and hoped now to be at rest; but vain thought! I was in the hands of the Philistines, and getting us up against a wall, they formed an impenetrable phalanx of men and brutes thoroughly determined that I should only get away from the spot on the legs of a donkey. Bethinking myself now that donkey-riding was a national institution, and seeing a fat Yankee (very like my Paris friend) mounted, being like myself hopeless of any other means of escape, I seized upon a bridle in hopes that I should then be left in peace. But this was the signal for a more furious onset, for, seeing that $I$ would at length ride, each one was determined that he alone should profit by the transaction, and a dozen animals were forced suddenly upon me and a dozen hands tried to lift me upon their respective beasts. But now my patience was exhausted, so, keeping firm hold of the bridle I had first taken with one hand, I hit right and left with the other, and calling upon my guide to do the same, we succeeded in clearing a little space around us. Now then behold your friend mounted upon a jackass in the streets of Alexandria, a boy behind holding by his tail and whipping him up, Charles (who had been lost sight of in the crowd) upon another, and my guide upon a third, and off we go among a crowd of Jews and Greeks, Turks and Arabs, and veiled women and yelling donkey-boys to see the city. We saw the bazaars and the slave market, where I was again nearly pulled to pieces 


\section{Early Letters}

for "backsheesh" (money), the mosques with their elegant minarets, and then the Pasha's new palace, the interior of which is most gorgeous.

We have seen lots of Turkish soldiers walking in comfortable irregularity; and, after feeling ourselves to be dreadful guys for two hours, returned to the hotel whence we were to start for the canal boats. You may think this account is exaggerated, but it is not; the pertinacity, vigour and screams of the Alexandrian donkey-drivers no description can do justice to. ... - Yours sincerely,

\section{Alfred R. Wallace.}

\section{To HIS Mother}

Singapore. April 30, 1854.

My dear Mother,-We arrived here safe on the 20th of this month, having had very fine weather all the voyage. On shore I was obliged to go to a hotel, which was very expensive, so I tried to get out into the country as soon as I could, which, however, I did not manage in less than a week, when I at last got permission to stay with a French Roman Catholic missionary who lives about eight miles out of the town and close to the jungle. The greater part of the inhabitants of Singapore are Chinese, many of whom are very rich, and all the villages about are almost entirely of Chinese, who cultivate pepper and gambir. Some of the English merchants here have splendid country houses. I dined with one to whom I brought an introduction. His house was most elegant, and full of magnificent Chinese and Japanese furniture. We are now at the Mission of Bukit Tima. The missionary speaks English, Malay and Chinese, as well as French, and is a very pleasant man. He has built a very pretty church here, and has about 300 Chinese converts. Having only been here four days, I cannot tell 


\section{Alfred Russel Wallace}

much about my collections yet. Insects, however, are plentiful. ... .

Charles gets on pretty well in health, and catches a few insects; but he is very untidy, as you may imagine by his clothes being all torn to pieces by the time we arrived here. He will no doubt improve and will soon be useful.

Malay is the universal language, in which all business is carried on. It is easy, and I am beginning to pick up a little, but when we go to Malacca shall learn it most, as there they speak nothing else.

I am very unfortunate with my watch. I dropped it on board and broke the balance-spring, and have now sent it home to Mr. Matthews to repair, as I cannot trust anyone here to do it. ...

Love to Fanny and Thomas.-I remain your affectionate son,

Alfred R. WaLlace.

\section{To HIs MOTHER}

Bukit Tama, Singapore. May 28, 1854.

My dear Mother,-I send you a few lines through G. Silk as I thought you would like to hear from me. I am very comfortable here living with a Roman Catholic missionary. . . . I send by this mail a small box of insects for Mr. Stevens-I think a very valuable one-and I hope it will go safely. I expected a letter from you by the last mail, but received only two Athenceums of March 18 and $25 . .$.

The forest here is very similar to that of South America. Palms are very numerous, but they are generally small and horridly spiny. There are none of the large and majestic species so abundant on the Amazon. I am so busy with insects now that $I$ have no time for anything else. I send 


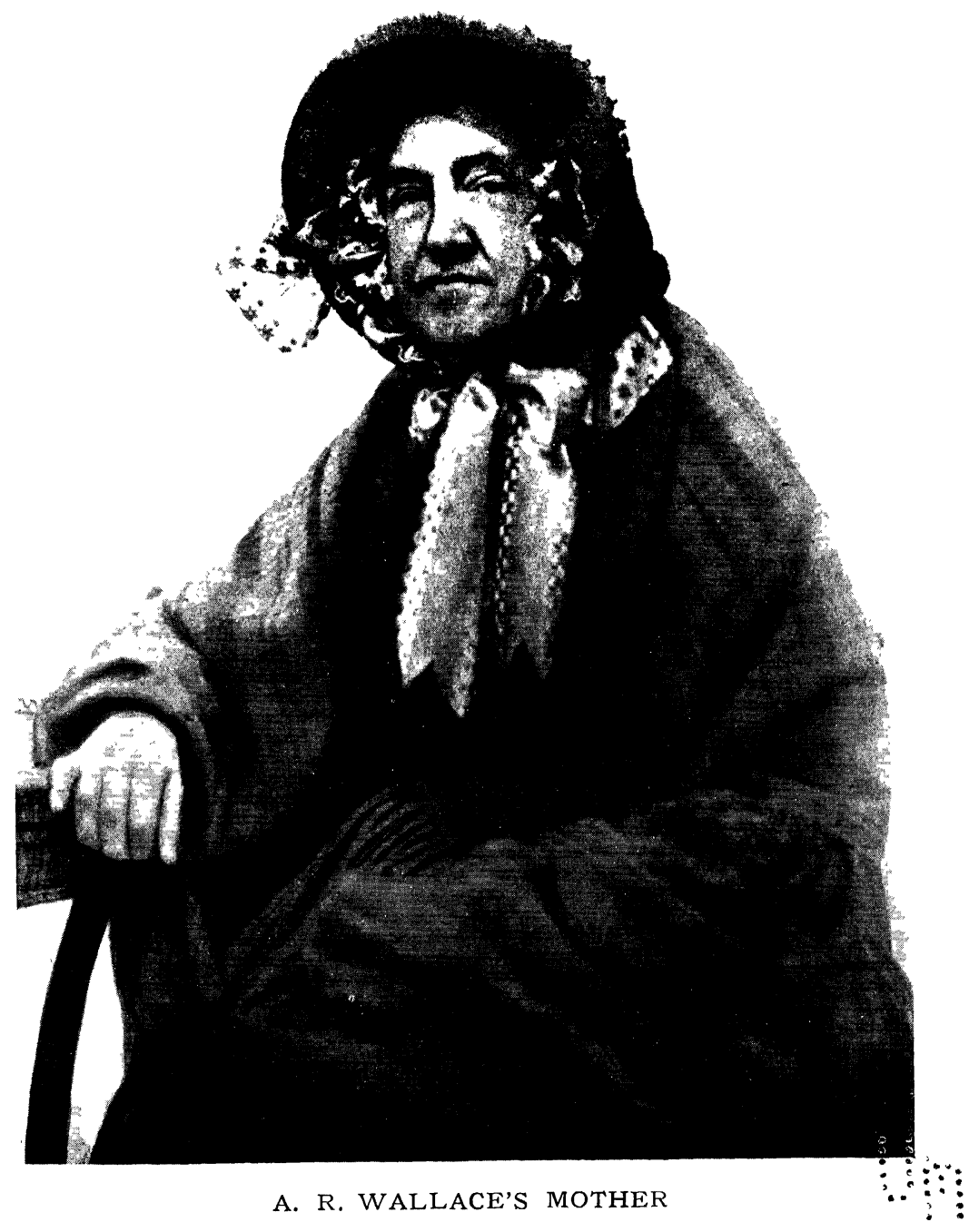




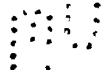




\section{Early Letters}

now about a thousand beetles to Mr. Stevens, and I have as many other insects still on hand which will form part of my next and principal consignment. Singapore is very rich in beetles, and before $I$ leave $I$ think $I$ shall have a most beautiful collection.

I will tell you how my day is now occupied. Get up at half-past five. Bath and coffee. Sit down to arrange and put away my insects of the day before, and set them safe out to dry. Charles mending nets, filling pincushions, and getting ready for the day. Breakfast at eight. Out to the jungle at nine. We have to walk up a steep hill to get to it, and always arrive dripping with perspiration. Then we wander about till two or three, generally returning with about 50 or 60 beetles, some very rare and beautiful. Bathe, change clothes, and sit down to kill and pin insects. Charles ditto with flies, bugs and wasps; I do not trust him yet with beetles. Dinner at four. Then to work again till six. Coffee. Read. If very numerous, work at insects till eight or nine. Then to bed.

Adieu, with love to all.-Your affectionate son,

Alfred R. Wallace.

\section{TO HIS MOTHER}

In the Jungle near Malacca. July, 1854.

My dear Mother,-As this letter may be delayed getting to Singapore I write at once, having an opportunity of sending to Malacca to-morrow. We have been here a week, living in a Chinese house or shed, which reminds me remarkably of my old Rio Negro habitation. I have now for the first time brought my "rede" into use, and find it very comfortable.

We came from Singapore in a small schooner with about fifty Chinese, Hindoos and Portuguese passengers, and were 


\section{Alfred Russel Wallace}

two days on the voyage, with nothing but rice and curry to eat, not having made any provision, it being our first experience of these country vessels. Malacca is an old Dutch city, but the Portuguese have left the strongest mark of their possession in the common language of the place being still theirs. I have now two Portuguese servants, a cook and a hunter, and find myself thus almost brought back again to Brazil by the similarity of language, the people, and the jungle life. In Malacca we stayed only two days, keing anxious to get into the country as soon as possible. I stayed with a Roman Catholic missionary; there are several here, each devoted to a particular part of the population, Portuguese, Chinese and wild Malays of the jungle. The gentleman we were with is building a large church, of which he is architect himself, and superintends the laying of every brick and the cutting of every piece of timber. Money enough could not be raised here, so he took a voyage round the world! and in the United States, California, and India got subscriptions sufficient to complete it.

It is a curious and not very creditable thing that in the English colonies of Singapore and Malacca there is not a single Protestant missionary; while the conversion, education and physical and moral improvement of the inhabitants (non-European) is entirely left to these French missionaries, who without the slightest assistance from our Government devote their lives to the Christianising and civilising of the varied populations which we rule over.

Here the birds are abundant and most beautiful, more so than on the Amazon, and I think I shall soon form a most beautiful collection. They are, however, almost all common, and so are of little value except that I hope they will be better specimens than usually come to England. My guns are both very good, but I find powder and shot 


\section{Early Letters}

in Singapore cheaper than in London, so I need not have troubled myself to take any. So far both $I$ and Charles have enjoyed excellent health. He can now shoot pretty well, and is so fond of it that I can hardly get him to do anything else. He will soon be very useful, if I can cure him of his incorrigible carelessness. At present I cannot trust him to do the smallest thing without watching that he does it properly, so that I might generally as well do it myself. I shall remain here probably two months, and then return to Singapore to prepare for a voyage to Cambodia or somewhere else, so do not be alarmed if you do not hear from me regularly. Love to all.-Your affectionate son,

Alfred R. Wallace.

\section{To His MoTHer}

Singapore. September 30, 1854.

My dear Mother,-I last wrote to you from Malacca in July. I have now just returned to Singapore after two months' hard work. At Malacca I had a pretty strong touch of fever with the old Rio Negro symptoms, but the Government doctor made me take a great quantity of quinine every day for a week together and so killed it, and in less than a fortnight $I$ was quite well and off to the jungle again. I see now how to treat the fever, and shall commence at once when the symptoms again appear. I never took half enough quinine in America to cure me. Malacca is a pretty place, and I worked very hard. Insects are not very abundant there, still by perseverance $I$ got a good number and many rare ones. Of birds, too, I made a good collection. I went to the celebrated Mount Ophir and ascended to the top. The walk was terrible-thirty miles through jungle, a succession of mud holes. My boots did good service. We lived there a week at the foot of the 


\section{Alfred Russel Wallace}

mountain, in a little hut built by our men, and I got some fine new butterflies there and hundreds of other new and rare insects. We had only rice and a little fish and tea, but came home quite well. The height of the mountain is about 4,000 feet. . . . Elephants and rhinoceroses, as well as tigers, are abundant there, but we had our usual bad luck in not seeing any of them.

On returning to Malacca I found the accumulations of two or three posts, a dozen letters and fifty newspapers. ...

I am glad to be safe in Singapore with my collections, as from here they can be insured. I have now a fortnight's work to arrange, examine, and pack them, and then in four months hence there will be some work for Mr. Stevens.

Sir James Brooke is here. I have called on him. He received me most cordially, and offered me every assistance at Sarawak. I shall go there next, as the missionary does not go to Cambodia for some months. Besides, I shall have some pleasant society at Sarawak, and shall get on in Malay, which is very easy, but I have had no practice-though still I can ask for most common things. My books and instruments arrived in beautiful condition. They looked as if they had been packed up but a day. Not so the unfortunate eatables. ....-I remain your affectionate son,

Alfred R. Wallace.

\section{To G. SILK}

Singapore. October 15, 1854.

Dear G.,-To-morrow I sail for Sarawak. Sir J. Brooke has given me a letter to his nephew, Capt. Brooke, to make me at home till he arrives, which may be a month, perhaps. I look forward with much interest to see what he has done 


\section{Early Letters}

and how he governs. I look forward to spending a very pleasant time at Sarawak. . . .

Sir W. Hooker's remarks are encouraging, but I cannot afford to collect plants. I have to work for a living, and plants would not pay unless I collect nothing else, which I cannot do, being too much interested in zoology. I should like a botanical companion like Mr. Spruce very much. We are anxiously expecting accounts of the taking of Sebastopol.

I am much obliged to Latham for quoting me, and hope to see it soon. That ought to make my name a little known. I have not your talent at making acquaintances, and find Singapore very dull. I have not found a single companion. I long for you to walk about with and observe the queer things in the streets of Singapore. The Chinamen and their ways are inexhaustibly amusing. My revolver is too heavy for daily use. I wish I had had a small one.-Yours sincerely,

ALFRED R. WALLACE.

\section{To AN UNKNOWN CORRESPONDENT ${ }^{1}$}

Si Munjon Coal Works, Borneo. May, 1855.

One of the principal reasons which induced me to come here was that it is the country of those most strange and interesting animals, the orang-utans, or "mias" of the Dyaks. In the Sarawak district, though scarce twenty miles distant, they are quite unknown, there being some boundary line in this short space which, obeying the inexplicable laws of distribution, they never pass. The Dyaks distinguish three different kinds, which are known in Europe by skulls or skeletons only, much confusion still existing in their synonymy, and the external characters of the adult animals being almost or quite unknown. I have already been fortunate enough to shoot two young animals

\footnotetext{
1 This letter may have been written for publication.
} 


\section{Alfred Russel Wallace}

of two of the species, which were easily distinguishable from each other, and I hope by staying here some time to get adult specimens of all the species, and also to obtain much valuable information as to their habits. The jungle here is exceedingly monotonous; palms are scarce and flowers almost wanting, except some species of dwarf gingerwort. It is high on the trees that flowers are alone to be found. . . . Oak trees are rather plentiful, as I have already found three species with red, brown, and black acorns. This is confirmatory of Dr. Hooker's statement that, contrary to the generally received opinion, oaks are equally characteristic of a tropical as of a temperate climate. I must make an exception to the scarcity of flowers, how. ever, tall slender trees occurring not unfrequently, whose stems are flower-bearing. One is a magnificent object, 12 or $15 \mathrm{ft}$. of the stem being almost hidden by rich orangecoloured flowers, which in the gloomy forest have, as I have before remarked of tropical insects under similar circumstances, an almost magical effect of brilliancy. Not less beautiful is another tree similarly clothed with spikes of pink and white berries.

The only striking features of the animal world are the hornbills, which are very abundant and take the place of the toucans of Brazil, though I believe they have no real affinity with them; and the immense flights of fruit-eating bats which frequently pass over us. They extend as far as the eye can reach, and continue passing for hours. By counting and estimation I calculated that at least 30,000 passed one evening while we could see them, and they continued on some time after dark. The species is probably the Pteropus edulis; its expanded wings are near $5 \mathrm{ft}$. across, and it flies with great ease and rapidity. Fruit seems so scarce in these jungles that it is a mystery where they find enough to supply such vast multitudes. 


\section{Early Letters}

Our mode of life here is very simple-rather too much so, as we have a continual struggle to get enough to eat. The Sarawak market is to a great extent supplied with rice, fowls, and sweet potatoes from this river, yet $I$ have been obliged to send to Sarawak to purchase these very articles. The reason is that the Dyaks are almost all in debt to the Malay traders, and will therefore not sell anything, fearful of not having sufficient to satisfy their creditors. They have now just got in their rice harvest, and though it is not a very abundant one there is no immediate pressure of hunger to induce them to earn anything by hunting or snaring birds, etc. This also prevents them from being very industrious in seeking for the " mias," though I have offered a high price for full-grown animals. The old men here relate with pride how many heads they have taken in their youth, and though they all acknowledge the goodness of the present Rajah's government, yet they think that if they could still take a few heads they would have better harvests. The more I see of uncivilised people, the better I think of human nature on the whole, and the essential differences between so-called civilised and savage man seem to disappear. Here are we, two Europeans surrounded by a population of Chinese, Malays, and Dyaks. The Chinese are generally considered, and with some truth, to be thieves, liars, and careless of human life, and these Chinese are coolies of the very lowest and least educated class. The Malays are invariably characterised as treacherous and bloodthirsty, and the Dyaks have only recently ceased to think head-taking an absolute necessity. We are two days' journey from Sarawak, where, though the Government is European, yet it only exists by the consent and support of the native population. Now I can safely say that in any part of Europe, if the same facilities for crime and disturbance existed, things would not go on so 


\section{Alfred Russel Wallace}

smoothly as they do here. We sleep with open doors and go about constantly unarmed; one or two petty robberies and a little private fighting have taken place among the Chinese, but the great proportion of them are quiet, honest, decent sort of men. They did not at first like the strictness and punctuality with which the English manager kept them to their work, and two or three ringleaders tried to get up a strike for short hours and higher wages, but Mr. C.'s energy and decision soon stopped this by sending off the ringleaders at once, and summoning all the Dyaks and Malays in the neighbourhood to his assistance in case of any resistance being attempted. It was very gratifying to see how rapidly they came up at his summons, and this display of power did much good, for since then everything has gone on smoothly. Preparations are now making for building a "joss house," a sure sign that the Chinese have settled to the work, and giving every promise of success in an undertaking which must have a vast influence on the progress of commerce and civilisation of Borneo and the surrounding countries. India, Australia, and every country with which they have communication must also be incalculably benefited by an abundant supply of good coal within two days' steam of Singapore. Let us wish success, then, to the Si Munjon Coal Works!-A. R. W.

\section{To His Sister, Mrs. Sims}

\section{Sadong River Borneo]. June 25, 1855.}

My dear Fanny, - . . . I am now obliged to keep fowls and pigs, or we should get nothing to eat. I have three pigs now and a China boy to attend to them, who also assists in skinning "orang-utans," which he and Charles are doing at this moment. I have also planted some onions and pumpkins, which were above ground in three days and 


\section{Early Letters}

are growing vigorously. I have been practising salting pork, and find I can make excellent pickled pork here, which $I$ thought was impossible, as everyone I have seen try has failed. It is because they leave it to servants, who will not take the necessary trouble. I do it myself. I shall therefore always keep pigs in the future. I find there will not be time for another box round the Cape, so must have a small parcel overland. I should much like my lasts, but nothing else, unless some canvas shoes are made.

If the young man my mother and Mr. Stevens mentioned comes, he can bring them. I shall write to Mr. Stevens about the terms on which I can take him. I am, however, rather shy about it, having hitherto had no one to suit me. As you seem to know him, I suppose he comes to see you sometimes. Let me know what you think of him. Do not tell me merely that he is "a very nice young man." Of course he is. So is Charles a very nice boy, but I could not be troubled with another like him for any consideration whatever. I have written to Mr. Stevens to let me know his character, as regards neatness and perseverance in doing anything he is set about. From you I should like to know whether he is quiet or boisterous, forward or shy, talkative or silent, sensible or frivolous, delicate or strong. Ask him whether he can live on rice and salt fish for a week on an occasion -whether he can do without wine or beer, and sometimes without tea, coffee or sugar-whether he can sleep on a board-whether he likes the hottest weather in Englandwhether he is too delicate to skin a stinking animalwhether he can walk twenty miles a day-whether he can work, for there is sometimes as hard work in collecting as in anything. Can he draw (not copy)? Can he speak French? Does he write a good hand? Can he make anything? Can he saw a piece of board straight? (Charles cannot, and every bit of carpenter work I have to do my. 


\section{Alfred Russel Wallace}

self.) Ask him to make you anything-a little card box, a wooden peg or bottle-stopper, and see if he makes them neat, straight and square. Charles never does anything the one or the other. Charles has now been with me more than a year, and every day some such conversation as this ensues: "Charles, look at these butterflies that you set out yesterday." "Yes, sir." "Look at that one-is it set out evenly ?" "No, sir." "Put it right then, and all the others that want it." In five minutes he brings me the box to look at. "Have you put them all right?" "Yes, sir." "There's one with the wings uneven, there's another with the body on one side, then another with the pin crooked. Put them all right this time." It most frequently happens that they have to go back a third time. Then all is right. If he puts up a bird, the head is on one side, there is a great lump of cotton on one side of the neck like a wen, the feet are twisted soles uppermost, or something else. In everything it is the same, what ought to be straight is always put crooked. This after twelve months' constant practice and constant teaching! And not the slightest sign of improvement. I believe he never will improve. Day after day I have to look over everything he does and tell him of the same faults. Another with a similar incapacity would drive me mad. He never, too, by any chance, puts anything away after him. When done with, everything is thrown on the floor. Every other day an hour is lost looking for knife, scissors, pliers, hammer, pins, or something he has mislaid. Yet out of doors he does very well-he collects insects well, and if I could get a neat, orderly person in the house $I$ would keep him almost entirely at out-of-door work and at skinning, which he does also well, but cannot put into shape. . . . - Your affectionate brother,

Alfred R. WALlace. 


\section{Early Letters}

TO HIS MOTHER

Sarawak. Christmas Day, 1855.

My dear Mother,-You will see I am spending a second Christmas Day with the Rajah. . . . I have lived a month with the Dyaks and have been a journey about sixty miles into the interior. I have been very much pleased with the Dyaks. They are a very kind, simple and hospitable people, and I do not wonder at the great interest Sir J. Brooke takes in them. They are more communicative and lively than the American Indians, and it is therefore more agreeable to live with them. In moral character they are far superior to either Malays or Chinese, for though head-taking has been a custom among them it is only as a trophy of war. In their own villages crimes are very rare. Ever since Sir J. has been here, more than twelve years, in a large population there has been but one case of murder in a Dyak tribe, and that one was committed by a stranger who had been adopted into the tribe. One wet day I got a piece of string to show them how to play " scratch cradle," and was quite astonished to find that they knew it better than I did and could make all sorts of new figures I had never seen. They were also very clever with tricks with string on their fingers, which seemed to be a favourite amusement. Many of the distant tribes think the Rajah cannot be a man. They ask all sorts of curious questions about him, whether he is not as old as the mountains, whether he cannot bring the dead to life, and $I$ have no doubt for many years after his death he will be looked upon as a deity and expected to come back again. I have now seen a good deal of Sir James, and the more I see of him the more I admire him. With the highest talents for government he combines the greatest goodness of heart and gentleness of manner. At the same time he has such confidence and determination, that he has put down with the 


\section{Alfred Russel Wallace}

greatest ease some conspiracies of one or two Malay chiefs against him. It is a unique case in the history of the world, for a European gentleman to rule over two conflicting races of semi-savages with their own consent, without any means of coercion, and depending solely upon them for protection and support, and at the same time to introduce the benefits of civilisation and check all crime and semibarbarous practices. Under his government, "running amuck," so frequent in all other Malay countries, has never taken place, and with a population of 30,000 Malays, all of whom carry their "creese" and revenge an insult by a stab, murders do not occur more than once in five or six years.

The people are never taxed but with their own consent, and Sir J.'s private fortune has been spent in the government and improvement of the country; yet this is the man who has been accused of injuring other parties for his own private interests, and of wholesale murder and butchery to secure his government! . . - -Your ever affectionate son,

Alfred R. Wallace.

To His Sister, Mrs. Sims

Bongapore. February 20, 1856.

My dear Fanny,- . . . I have now left Sarawak, where I began to feel quite at home, and may perhaps never return to it again; but I shall always look back with pleasure to my residence there and to my acquaintance with Sir James Brooke, who is a gentleman and a nobleman in the noblest sense of both words. . . .

Charles has left me. He has stayed with the Bishop of Sarawak, who wants teachers and is going to try to educate him for one. I offered to take him on with me, paying him a fair price for all the insects, etc., he collected, but he pre- 


\section{Early Letters}

ferred to stay. I hardly know whether to be glad or sorry he has left. It saves me a great deäl of trouble and annoyance, and I feel it quite a relief to be without him. On the other hand, it is a considerable loss for me, as he had just begun to be valuable in collecting. I must now try and teach a China boy to collect and pin insects. My collections in Borneo have been very good, but some of them will, I fear, be injured by the long voyages of the ships. I have collected upwards of 25,000 insects, besides birds, shells, quadrupeds, and plants. The day I arrived here a vessel sailed for Macassar, and I fear I shall not have another chance for two months unless $I$ go a roundabout way, and perhaps not then, so I have hardly made up my mind what to do.-Your affectionate brother, ALfRed R. WALLACE.

\section{To His Brother-IN-LaW, Thomas Sims}

Singapore. [Probably about March, 1856.]

Dear Thomas,- . . . You and Fanny talk of my coming back for a trifling sore as if $I$ was within an omnibus ride of Conduit St. I am now perfectly well, and only waiting to go eastward. The far east is to me what the far west is to the Americans. They both meet in California, where I hope to arrive some day. I quite enjoy being a few days at Singapore now. The scene is at once so familiar and strange. The half-naked Chinese coolies, the neat shopkeepers, the clean, fat, old, long-tailed merchants, all as busy and full of business as any Londoners. Then the handsome Klings, who always ask double what they take, and with whom it is most amusing to bargain. The crowd of boatmen at the ferry, a dozer begging and disputing for a farthing fare, the Americans, the Malays, and the Portuguese make up a scene doubly interesting to me now that I know something about them 


\section{Alfred Russel Wallace}

and can talk to them in the general language of the place. The streets of Singapore on a fine day are as crowded and busy as Tottenham Court Road, and from the variety of nations and occupations far more interesting. I am more convinced than ever that no one can appreciate a new country in a short visit. After two years in the country I only now begin to understand Singapore and to marvel at the life and bustle, the varied occupations, and strange population, on a spot which so short a time ago was an uninhabited jungle. . . - Yours affectionately,

ALFRED R. WallaCE.

\section{To His Sister, Mrs. Sims}

Singapore. April 21, 1856.

My dear Fanny,-I believe I wrote to you last mail, and have now little to say except that I am still a prisoner in Singapore and unable to get away to my land of promise, Macassar, with whose celebrated oil you are doubtless acquainted. I have been spending three weeks with my old friend the French missionary, going daily into the jungle, and fasting on Fridays on omelet and vegetables, a most wholesome custom which I think the Protestants were wrong to leave off. I have been reading Huc's travels in China in French, and talking with a French missionary just arrived from Tonquin. I have thus obtained a great deal of information about these countries and about the extent of the Catholic missions in them, which is astonish. ing. How is it that they do their work so much more thoroughly than the Protestant missionaries? In Cochin China, Tonquin, and China, where all Christian missionaries are obliged to live in secret and are subject to persecution, expulsion, and often death, yet every province, even those farthest in the interior of China, have their regular 


\section{Early Letters}

establishment of missionaries constantly kept up by fresh supplies who are taught the languages of the countries they are going to at Penang or Singapore. In China there are near a million Catholics, in Tonquin and Cochin China more than half a million! One secret of their success is the cheapness of their establishments. A missionary is

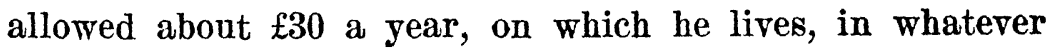
country he may be. This has two good effects. A large number of missionaries can be employed with limited funds, and the people of the countries in which they reside, seeing they live in poverty and with none of the luxuries of life, are convinced they are sincere. Most are Frenchmen, and those I have seen or heard of are welleducated men, who give up their lives to the good of the people they live among. No wonder they make converts, among the lower orders principally. For it must be a great comfort to these poor people to have a man among them to whom they can go in any trouble or distress, whose sole object is to comfort and advise them, who visits them in sickness, who relieves them in want, and whom they see living in daily danger of persecution and death only for their benefit.

You will think they have converted me, but in point of doctrine I think Catholics and Protestants are equally wrong. As missionaries I think Catholics are best, and I would gladly see none others, rather than have, as in New Zealand, sects of native Dissenters more rancorous against each other than in England. The unity of the Catholics is their strength, and an unmarried clergy can do as missionaries what married men can never undertake. I have written on this subject because $I$ have nothing else to write about. Love to Thomas and Edward.-Believe me, dear Fanny, your ever affectionate brother,

Alfred R. Wallace. 


\section{Alfred Russel Wallace}

\section{To His Sister, Mrs. Sims}

Macassar. December 10, 1856.

My dear Fanny,-I have received yours of September, and my mother's of October, and as I am now going out of reach of letters for six months I must send you a few lines to let you know that I am well and in good spirits, though rather disappointed with the celebrated Macassar. - . For the last fortnight, since I came in from the country, I have been living here rather luxuriously, getting good rich cow's milk to my tea and coffee, very good bread and excellent Dutch butter (3s. a lb.). The bread here is raised with toddy just as it is fermenting, and it imparts a peculiar sweet taste to the bread which is very nice. At last, too, there is some fruit here. The mangoes have just come in, and they are certainly magnificent. The flavour is something between a peach and a melon, with the slightest possible flavour of turpentine, and very juicy. They say they are unwholesome, and it is a good thing for me I am going away now. When I come back there will be not one to be had. . . . - I remain, dear Fanny, your ever affectionate brother,

A. R. Wallace.

\section{H. W. Bates to A. R. Wallace}

Tunantins, Upper Amazon. November 19, 1856.

Dear Wallace,- - . I received about six months ago a copy of your paper in the Annals on "The Laws which have Governed the Introduction of New Species." I was startled at first to see you already ripe for the enunciation of the theory. You can imagine with what interest I read and studied it, and I must say that it is perfectly well done. The idea is like truth itself, so simple and obvious that those who read and understand it will be struck by its simplicity; 


\section{Early Letters}

and yet it is perfectly original. The reasoning is close and clear, and although so brief an essay, it is quite complete, embraces the whole difficulty, and anticipates and annihilates all objections.

Few men will be in a condition to comprehend and appreciate the paper, but it will infallibly create for you a high and sound reputation. The theory I quite assent to, and, you know, was conceived by me also, but I profess that I could not have propounded it with so much force and completeness.

Many details I could supply, in fact a great deal remains to be done to illustrate and confirm the theory: a new method of investigating and propounding zoology and botany inductively is necessitated, and new libraries will have to be written; in part of this task I hope to be a labourer for many happy and profitable years. What a noble subject would be that of a monograph of a group of beings peculiar to one region but offering different species in each province of it-tracing the laws which connect together the modifications of forms and colour with the local circumstances of a province or station-tracing as far as possible the actual affiliation of the species.

Two of such groups occur to me at once, in entomology, in Heliconiidæ and Erotylidæ of South America; the latter I think more interesting than the former for one reasonthe species are more local, having feebler means of locomotion than the Heliconiidæ. . . . - Yours very truly,

HenRy Walter Bates.

\section{To H. W. BATES}

Amboyna. January 4, 1858.

My dear Bates,-My delay of six months in answering your very interesting and most acceptable letter dated F 


\section{Alfred Russel Wallace}

Tunantins, 19th November, 1856, has not, I assure you, arisen either from laziness or indifference, but really from pressure of business and an unsettled state of mind. I received your letter at Macassar on my return in July last from a seven months' voyage and residence in the Aru Islands close to New Guinea. I found letters from Australia, California, yourself, Spruce, Darwin, home, and a lot of interesting Stevensian dispatches. I had six months' collections (mostly in bad condition owing to dampness and sea air) to examine and pack; about 7,000 insects having to be gone over individually and many of them thoroughly cleaned, besides an extensive collection of birds. I was thus occupied incessantly for a month, and then immediately left for a new locality in the interior, where I stayed three months, during which time I had most of my correspondence to answer, and was besides making some collections so curious and interesting that I did not feel inclined to answer your letter till I could tell you something about them.

At the end of October I returned to Macassar, packed up my collection, and left by steamer for Ternate, via this place, where $I$ have stayed a month, had some good collecting, and it is now, on the day of my departure, having all my boxes packed and nothing to do, that $I$ commence a letter to you.

To persons who have not thought much on the subject I fear my paper on the succession of species will not appear so clear as it does to you. That paper is, of course, only the announcement of the theory, not its development. I have prepared the plan and written portions of an extensive work embracing the subject in all its bearings and endeavouring to prove what in the paper $I$ have only indicated. It was the promulgation of Forbes's theory which led me to write and publish, for I was annoyed to see such 


\section{Early Letters}

an ideal absurdity put forth when such a simple hypothesis will explain all the facts.

I have been much gratified by a letter from Darwin, in which he says that he agrees with "almost every word", of my paper. He is now preparing for publication his great work on species and varieties, for which he has been collecting information twenty years. He may save me the trouble of writing the second part of my hypothesis by proving that there is no difference in nature between the origin of species and varieties, or he may give me trouble by arriving at another conclusion, but at all events his facts will be given for me to work upon. Your collections and my own will furnish most valuable material to illustrate and prove the universal applicability of the hypothesis. The connection between the succession of affinities and the geographical distribution of a group, worked out species by species, has never yet been shown as we shall be able to show it. In this Archipelago there are two distinct faunas rigidly circumscribed, which differ as much as those of South America and Africa, and more than those of Europe and North America : yet there is nothing on the map or on the face of the islands to mark their limits. The boundary line often passes between islands closer than others in the same group. I believe the western part to be a separated portion of continental Asia, the eastern the fragmentary prolongation of a former Pacific continent. In mammalia and birds the distinction is marked by genera, families, and even orders confined to one region; in insects by a number of genera and little groups of peculiar species, the families of insects having generally a universal distribution. 


\section{Alfred Russel Wallace}

Ternate. January 25, 1858.

I have not done much here yet, having been much occupied in getting a house repaired and put in order. This island is a volcano with a sloping spur on which the town is situated. About ten miles to the east is the coast of the large Island of Gilolo, perhaps the most perfect entomological terra incognita now to be found. I am not aware that a single insect has ever been collected there, and cannot find it given as the locality of any insects in my catalogues or descriptions. In about a week I go for a month collecting there, and then return to prepare for a voyage to New Guinea. I think I shall stay in this place two or three years, as it is the centre of a most interesting and almost unknown region. Every house here was destroyed in 1840 by an earthquake during an eruption of the volcano....

What great political events have passed since we left England together! And the most eventful for England, and perhaps the most glorious, is the present mutiny in India, which has proved British courage and pluck as much as did the famed battles of Balaclava and Inkerman. I believe that both India and England will gain in the end by the fearful ordeal. When do you mean returning for good? If you go to the Andes you will, I think, be disappointed, at least in the number of species, especially of Coleoptera. My experience here is that the low grounds are much the most productive, though the mountains generally produce a few striking and brilliant species....-Yours sincerely,

Alfred R. WaLlace. 


\section{Early Letters}

To F. Bates

Ternate. March 2, 1858.

My dear Mr. Bates,-When I received your very acceptable letter (a month ago) I had just written one to your brother, which I thought I could not do better than send to you to forward to him, as I shall thereby be able to confine myself solely to the group you are studying and to other matters touched upon in your letter. I had heard from Mr. Stevens some time ago that you had begun collecting exotic Geodephaga, but were confining yourself to one or two illustrations of each genus. I was sure, however, that you would soon find this unsatisfactory. Nature must be studied in detail, and it is the wonderful variety of the species of a group, their complicated relations and their endless modification of form, size and colours, which constitute the pre-eminent charm of the entomologist's study. It is with the greatest satisfaction, too, I hail your accession to the very limited number of collectors and students of exotic insects, and sincerely hope you may be sufficiently favoured by fortune to enable you to form an extensive collection and to devote the necessary time to its study and ultimately to the preparation of a complete and useful work. Though I cannot but be pleased that you are able to do so, I am certainly surprised to find that you indulge in the expensive luxury of from three to seven specimens of a species. I should have thought that in such a very extensive group you would have found one or, at most, a pair quite sufficient. I fancy very few collectors of exotic insects do more than this, except where they can obtain additional specimens by gift or by exchange. Your remarks on my collections are very interesting to me, especially as I have kept descriptions with many outline figures of my Malacca and Sarawak Geodephaga, so that with one or two exceptions 


\section{Alfred Russel Wallace}

I can recognise and perfectly remember every species you mention. ...

Now with regard to your request for notes of habits, etc. I shall be most willing to comply with it to some extent, first informing you that I look forward to undertaking on my return to England a "Coleoptera Malayana," to contain descriptions of the known species of the whole Archipelago, with an essay on their geographical distribution, and an account of the habits of the genera and species from my own observations. Of course, therefore, I do not wish any part of my notes to be published, as this will be a distinctive feature of the work, so little being known of the habits, stations and modes of collecting exotic Coleoptera. ... .

You appear to consider the state of entomological literature flourishing and satisfactory: to $m e$ it seems quite the contrary. The number of unfinished works and of others with false titles is disgraceful to science. . . .

I think ... on the whole we may say that the Archipelago is very rich, and will bear a comparison even with the richest part of South America. In the country between Ega and Peru there is work for fifty collectors for fifty years. There are hundreds and thousands of Andean valleys every one of which would bear exploring. Here it is the same with islands. I could spend twenty years here were life long enough, but feel I cannot stand it, away from home and books and collections and comforts, more than four or five, and then I shall have work to do for the rest of my life. What would be the use of accumulating materials which one could not have time to work up? I trust your brother may give us a grand and complete work on the Coleoptera of the Amazon Valley, if not of all South America. . . - Yours faithfully, Alfred R. Wallace. 


\section{Early Letters}

To HIS MOTHER

October 6, 1858.

My dear Mother,-... I have just returned from a short trip, and am now about to start on a longer one, but to a place where there are some soldiers, a doctor and engineer who speak English, so if it is good for collecting I shall stay there some months. It is Batchian, an island on the south-west side of Gilolo, about three or four days' sail from Ternate. I am now quite recovered from my New Guinea voyage and am in good health.

I have received letters from Mr. Darwin and Dr. Hooker, two of the most eminent naturalists in England, which has highly gratified me. I sent Mr. Darwin an essay on a subject on which he is now writing a great work. He showed it to Dr. Hooker and Sir C. Lyell, who thought so highly of it that they immediately read it before the Linnean Society. This assures me the acquaintance and assistance of these eminent men on my return home.

Mr. Stevens also tells me of the great success of the Aru collection, of which $£ 1,000$ worth has actually been sold. This makes me hope I may soon realise enough to live upon and carry out my long cherished plans of a country life in old England.

If I had sent the large and handsome shells from Aru, which are what you expected to see, they would not have paid expenses, whereas the cigar box of small ones has sold for $£ 50$. You must not think I shall always do so well as at Aru; perhaps never again, because no other collections will have the novelty, all the neighbouring countries producing birds and insects very similar, and many even the very same. Still, if $I$ have health $I$ fear not to do very well. I feel little inclined now to go to California; as soon as $I$ have finished my exploration of this region $I$ 


\section{Alfred Russel Wallace}

shall be glad to return home as quickly and cheaply as possible. It will certainly be by way of the Cape or by second class overland. May I meet you, dear old Mother, and all my other relatives and friends, in good health. Perhaps John and his trio will have had the start of me. . . .

\section{TO H. W. Bates}

Ceram. November 25, 1859.

Dear Bates,-Allow me to congratulate you on your safe arrival home with all your treasures; a good fortune which I trust is this time ${ }^{1}$ reserved for me. I hope you will write to me and tell me your projects. Stevens hinted at your undertaking a "Fauna of the Amazon Valley." It would be a noble work, but one requiring years of labour, as of course you would wish to incorporate all existing materials and would have to spend months in Berlin and Milan and Paris to study the collections of Spix, Natterer, Oscolati, Castituan and others, as well as most of the chief private collections of Europe. I hope you may undertake it and bring it to a glorious conclusion. I have long been contemplating such a work for this Archipelago, but am convinced that the plan must be very limited to be capable of completion. ...-I remain, dear Bates, yours very sincerely,

AlFred R. W.ALlace.

\section{To H. W. Bates}

Ternate. December 24, 1860.

Dear Bates,-Many thanks for your long and interesting letter. I have myself suffered much in the same way as you describe, and I think more severely. The kind of tadium vitoe you mention I also occasionally experience here. I impute it to a too monotonous existence.

1 A reference to the loss of his earlier collection (p. 29). 


\section{Early Letters}

I know not how or to whom to express fully my admiration of Darwin's book. To him it would seem flattery, to others self-praise; but I do honestly believe that with however much patience $I$ had worked up and experimented on the subject, I could never have approached the completeness of his book-its vast accumulation of evidence, its overwhelming argument, and its admirable tone and spirit. I really feel thankful that it has not been left to me to give the theory to the public. Mr. Darwin has created a new science and a new philosophy, and $I$ believe that never has such a complete illustration of a new branch of human knowledge been due to the labours and researches of a single man. Never have such vast masses of widely scattered and hitherto utterly disconnected facts been combined into a system, and brought to bear upon the establishment of such a grand and new and simple philosophy !. . - In haste, yours faithfully,

AlfRed R. Wallace.

\section{To His Brother-IN-LaW, Thomas Sims}

\section{Delli, Timor. March 15, 1861.1}

My dear Thomas,-I will now try and write you a few lines in reply to your last three letters, which $I$ have not before had time and inclination to do. First, about your one-eyed and two-eyed theory of art, etc. etc. I do not altogether agree with you. We do not see all objects wider with two eyes than with one. A spherical or curved object we do see so, because our right and left eye each see a portion of the surface not seen by the other, but for that very reason the portion seen perfectly with both eyes is less than with one. Thus [see diagram on next page] we only see from A to A with both our eyes, the two side portions $A b$ Ab being

\footnotetext{
Museum.

1 The original of this letter is in the possession of the Trustees of the British
} 


\section{Alfred Russel Wallace}

seen with but one eye, and therefore (when we are using both eyes) being seen obscurely. But if we look at a flat object, whether square or oblique to the line of vision, we see it of exactly the same size with two eyes as with one because the one eye can see no part of it that the other does not see also. But' in painting $I$ believe that this difference of proportion, where it does exist, is far too small to be given by any artist and also too small to affect the picture if given.

Again, I entirely deny that by any means the exact effect of a landscape with objects at various distances from the eye

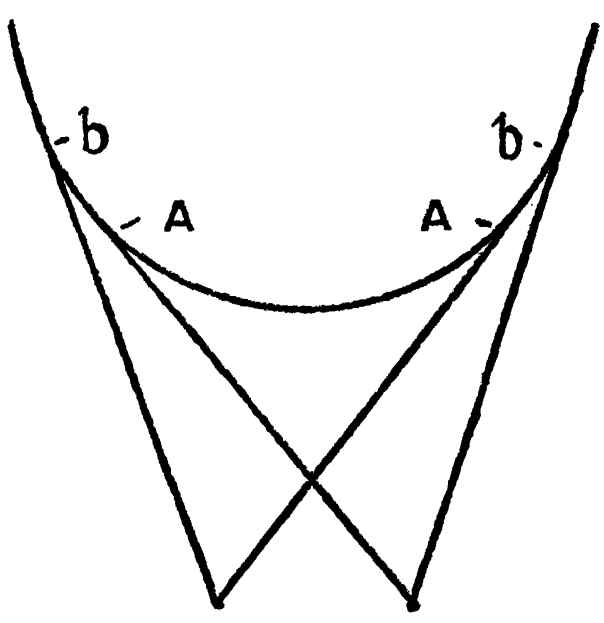
can be given on a flat surface; and moreover that the monocular clear outlined view is quite as true and good on the whole as the binocular hazy outlined view, and for this reason: we cannot and do not see clearly or look at two objects at once, if at different distances from us. In a real view our eyes are directed successively at every object, which we then see clearly and with distinct outlines, everything else-nearer and farther-being indistinct; but being able to change the focal angle of our two eyes and their angle of direction with great rapidity, we are enabled to glance rapidly at each object in succession and thus obtain a general and detailed view of the whole. A house, a tree, a spire, the leaves of a shrub in the foreground, are each seen (while we direct our eyes to them) with perfect definition and sharpness of outline. Now a monocular photo gives the clearness of outline and accuracy of definition, and thus 


\section{Early Letters}

represents every individual part of a landscape just as we see it when looking at that part. Now I maintain that this is right, because no painting can represent an object both distinct and indistinct. The only question is, Shall a painting show us objects as we see them when looking at them, or as we see them when looking at something else near them? The only approach painters can make to this varying effect of binocular vision, and what they often do, is to give the most important and main feature of their painting distinct as we should see it when looking at it in nature, while all around has a subdued tone and haziness of outline like that produced by seeing the real objects when our vision is not absolutely directed to them. But then if, as in nature, when you turn your gaze to one of these objects in order to see it clearly, you cannot do so, this is a defect. Again, I believe that we actually see in a good photograph better than in nature, because the best camera lenses are more perfectly adjusted than our eyes, and give objects at varying distances with better definition. Thus in a picture we see at the same time near and distinct objects easily and clearly, which in reality we cannot do. If we could do so, everyone must acknowledge that our vision would be so much the more perfect and our appreciation of the beauties of nature more intense and complete; and in so far as a good landscape painting gives us this power it is better than nature itself; and I think this may account for that excessive and entrancing beauty of a good landscape or of a good panorama. You will think these ideas horribly heterodox, but if we all thought alike there would be nothing to write about and nothing to learn. I quite agree with you, however, as to artists using both eyes to paint and to see their paintings, but I think you quite mistake the theory of looking through the "catalogue"; it is not because the picture can be seen better with one eye, but 


\section{Alfred Russel Wallace}

because its effect can be better seen when all lateral objects are hidden-the catalogue does this. A double tube would be better, but that cannot be extemporised so easily. Have you ever tried a stereograph taken with the camera only the distance apart of the eyes? That must give nature. When the angle is greater the views in the stereoscope show us, not nature, but a perfect reduced model of nature seen nearer the eye.

It is curious that you should put Turner and the PreRaphaelites as opposed and representing binocular and monocular painting when Turner himself praises up the Pre-Raphaelites and calls Holman Hunt the greatest living painter!! . . .

Now for Mr. Darwin's book. You quite misunderstand Mr. D.'s statement in the preface and his sentiments. I have, of course, been in correspondence with him since I first sent him my little essay. His conduct has been most liberal and disinterested. I think anyone who reads the Linnean Society papers and his book will see it. I do back him up in his whole round of conclusions and look upon him as the Newton of Natural History.

You begin by criticising the title. Now, though I consider the title admirable, I believe it is not Mr. Darwin's but the Publisher's, as you are no doubt aware that publishers will have a taking title, and authors must and do give way to them. Mr. D. gave me a different title before the book came out. Again, you misquote and misunderstand Huxley, who is a complete convert. Prof. Asa Gray and Dr. Hooker, the two first botanists of Europe and America, are converts. And Lyell, the first geologist living, who has all his life written against such conclusions as Darwin arrives at, is a convert and is about to declare or already has declared his conversion-a noble and almost unique example of a man yielding to conviction on a subject 


\section{Early Letters}

which he has taught as a master all his life, and confessing that he has all his life been wrong.

It is clear that you have not yet sufficiently read the book to enable you to criticise it. It is a book in which every page and almost every line has a bearing on the main argument, and it is very difficult to bear in mind such a variety of facts, arguments and indications as are brought forward. It was only on the fifth perusal that I fully appreciated the whole strength of the work, and as I had been long before familiar with the same subjects I cannot but think that persons less familiar with them cannot have any clear idea of the accumulated argument by a single perusal.

Your objections, so far as I can see anything definite in them, are so fully and clearly anticipated and answered in the book itself that it is perfectly useless my saying any. thing about them. It seems to me, however, as clear as daylight that the principle of Natural Selection must act in nature. It is almost as necessary a truth as any of mathematics. Next, the effects produced by this action cannot be limited. It cannot be shown that there is any limit to them in nature. Again, the millions of facts in the numerical relations of organic beings, their geographical distribution, their relations of affinity, the modification of their parts and organs, the phenomena of intercrossing, embryology and morphology-all are in accordance with his theory, and almost all are necessary results from it; while on the other theory they are all isolated facts having no connection with each other and as utterly inexplicable and confusing as fossils are on the theory that they are special creations and are not the remains of animals that have once lived. It is the vast chaos of facts, which are explicable and fall into beautiful order on the one theory, which are inexplicable and remain a chaos on the other, 


\section{Alfred Russel Wallace}

which I think must ultimately force Darwin's views on any and every reflecting mind. Isolated difficulties and objections are nothing against this vast cumulative argument. The human mind cannot go on for ever accumulating facts which remain unconnected and without any mutual bearing and bound together by no law. The evidence for the production of the organic world by the simple laws of inheritance is exactly of the same nature as that for the production of the present surface of the earth-hills and valleys, plains, rocks, strata, volcanoes, and all their fossil remains -by the slow and natural action of natural causes now in operation. The mind that will ultimately reject Darwin must (to be consistent) reject Lyell also. The same arguments of apparent stability which are thought to disprove that organic species can change will also disprove any change in the inorganic world, and you must believe with your forefathers that each hill and each river, each inland lake and continent, were created as they stand, with their various strata and their various fossils-all appearances and arguments to the contrary notwithstanding. I can only recommend you to read again Darwin's account of the horse family and its comparison with pigeons; and if that does not convince and stagger you, then you are unconvertible. I do not expect Mr. Darwin's larger work will add anything to the general strength of his argument. It will consist chiefly of the details (often numerical) and experiments and calculations of which he has already given the summaries and results. It will therefore be more confusing and less interesting to the general reader. It will prove to scientific men the accuracy of his details, and point out the sources of his information, but as not one in a thousand readers will ever test these details and references the smaller work will remain for general purposes the best. ... 


\section{Early Letters}

I see that the Great Exhibition for 1862 seems determined on. If so it will be a great inducement to me to cut short the period of my banishment and get home in time to see it. I assure you $I$ now feel at times very great longings for the peace and quiet of home-very much weariness of this troublesome, wearisome, wandering life. I have lost some of that elasticity and freshness which made the overcoming of difficulties a pleasure, and the country and people are now too familiar to me to retain any of the charms of novelty which gild over so much that is really monotonous and disagreeable. My health, too, gives way, and I cannot now put up so well with fatigue and privations as at first. All these causes will induce me to come home as soon as possible, and I think I may promise, if no accident happens, to come back to dear and beautiful England in the summer of next year. C. Allen will stay a year longer and complete the work which I shall not be able to do.

I have been pretty comfortable here, having for two months had the society of Mr. Geach, a Cornish mining engineer who has been looking for copper here. He is a very intelligent and pleasant fellow, but has now left. Another Englishman, Capt. Hart, is a resident here. He has a little house on the foot of the hills two miles out of town; I have a cottage (which was Mr. Geach's) a quarter of a mile farther. He is what you may call a speculative man : he reads a good deal, knows a little and wants to know more, and is fond of speculating on the most abstruse and unattainable points of science and philosophy. You would be astonished at the number of men among the captains and traders of these parts who have more than an average amount of literary and scientific taste; whereas among the naval and military officers and various Government officials very few have any such taste, but find their only amusements in card-playing and dissipation. Some of 


\section{Alfred Russel Wallace}

the most intelligent and best informed Dutchmen $I$ have met with are trading captains and merchants.

This country much resembles Australia in its physical features, and is very barren compared with most of the other islands. . . . It is very rugged and mountainous, having no true forests, but a scanty vegetation of gum trees with a few thickets in moist places. It is consequently very poor in insects, and in fact will hardly pay my expenses; but having once come here I may as well give it a fair trial. Birds are tolerably abundant, but with few exceptions very dull coloured. I really believe the whole series of birds of the tropical island of Timor are less beautiful and brightcoloured than those of Great Britain. In the mountains potatoes, cabbages and wheat are grown in abundance, and so we get excellent pure bread made by Chinamen in Delli. Fowls, sheep, pigs and onions are also always to be had, so that it is the easiest country to live in I have yet met with, as in most other places one is always doubtful whether a dinner can be obtained. I have been a trip to the hills and stayed ten days in the clouds, but it was very wet, being the wrong season. ...

Having now paid you off my literary debts, I trust you will give me credit again for some long letters on things in general. Address now to care of Hamilton, Gray and Co., Singapore, and with love and remembrances to all friends, I remain, my dear Thomas, yours very faithfully,

AlFRed R. WaLlace.

P.S.- . . Will you, next time you visit my mother, make me a little plan of her cottage, showing the rooms and their dimensions, so that I may see if there will be room enough for me on my return? I shall want a goodsized room for my collections, and when $I$ can decide exactly on my return it would be as well to get a little larger house 


\section{Early Letters}

beforehand if necessary. Please do not forget this.-Yours, A. R. W.

P.S.-Write by next mail, as circumstances have occurred which make it possible I may return home this year.-A. R. W.

P.S.-You allude in your last letter to a subject I never touch upon because I know we cannot agree upon it. However, I will now say a few words, that you may know my opinions, and if you wish to convert me to your way of thinking, take more vigorous measures to effect it. You intimate that the happiness to be enjoyed in a future state will depend upon, and be a reward for, our belief in certain doctrines which you believe to constitute the essence of true religion. You must think, therefore, that belief is voluntary and also that it is meritorious. But I think that a little consideration will show you that belief is quite independent of our will, and our common expressions show it. We say, "I wish I could believe him innocent, but the evidence is too clear" ; or, "Whatever people may say, I can never believe he can do such a mean action." Now, suppose in any similar case the evidence on both sides leads you to a certain belief or disbelief, and then a reward is offered you for changing your opinion. Can you really change your opinion and belief, for the hope of reward or the fear of punishment? Will you not say, "As the matter stands I can't change my belief. You must give me proofs that I am wrong or show that the evidence $I$ have heard is false, and then $I$ may change my belief" ? It may be that you do get more and do change your belief. But this change is not voluntary on your part. It depends upon the force of evidence upon your individual mind, and the evidence remaining the same and your mental faculties remaining unimpaired-you cannot believe otherwise any more than you can fly.

Belief, then, is not voluntary. How, then, can it be 


\section{Alfred Russel Wallace}

meritorious? When a jury try a case, all hear the same evidence, but nine say "Guilty" and three " Not guilty," according to the honest belief of each. Are either of these more worthy of reward on that account than the others? Certainly yon will say No! But suppose beforehand they all know or suspect that those who say "Not guilty" will be punished and the rest rewarded: what is likely to be the result? Why, perhaps six will say "Guilty" honestly believing it, and glad they can with a clear conscience escape punishment; three will say " Not guilty" boldly, and rather bear the punishment than be false or dishonest; the other three, fearful of being convinced against their will, will carefully stop their ears while the witnesses for the defence are being examined, and delude themselves with the idea they give an honest verdict because they have heard only one side of the evidence. If any out of the dozen deserve punishment, you will surely agree with me it is these. Belief or disbelief is therefore not meritorious, and when founded on an unfair balance of evidence is blameable.

Now to apply the principles to my own case. In my early youth I heard, as ninety-nine-hundredths of the world do, only the evidence on one side, and became impressed with a veneration for religion which has left some traces even to this day. I have since heard and read much on both sides, and pondered much upon the matter in all its bearings. I spent, as you know, a year and a half in a clergyman's family and heard almost every Tuesday the very best, most earnest and most impressive preacher it has ever been my fortune to meet with, but it produced no effect whatever on my mind. I have since wandered among men of many races and many religions. I have studied man, and nature in all its aspects, and I have sought after truth. In my solitude I have pondered much on the incomprehensible subjects of space, eternity, life and death. I think I have 


\section{Early Letters}

fairly heard and fairly weighed the evidence on both sides, and I remain an utter disbeliever in almost all that you consider the most sacred truths. I will pass over as utterly contemptible the oft-repeated accusation that sceptics shut out evidence because they will not be governed by the morality of Christianity. You I know will not believe that in my case, and $I$ know its falsehood as a general rule. I only ask, Do you think I can change the self-formed convictions of twenty-five years, and could you think such a change would have anything in it to merit reward from justice? I am thankful I can see much to admire in all religions. To the mass of mankind religion of some kind is a necessity. But whether there be a God and whatever be His nature; whether we have an immortal soul or not, or whatever may be our state after death, I can have no fear of having to suffer for the study of nature and the search for truth, or believe that those will be better off in a future state who have lived in the belief of doctrines inculcated from childhood, and which are to them rather a matter of blind faith than intelligent conviction.-A. R. W.

This for yourself; show the letter only to my mother.

\section{To His Mother}

Sourabaya, Java. July 20, 1861.

My dear Mother,-I am, as you will see, now commencing my retreat westwards, and have left the wild and savage Moluccas and New Guinea for Java, the Garden of the East, and probably without any exception the finest island in the world. My plans are to visit the interior and collect till November, and then work my way to Singapore so as to return home and arrive in the spring. Travelling here will be a much pleasanter business than in any other country $I$ have visited, as there are good roads, regular posting stages, 


\section{Alfred Russel Wallace}

and regular inns or lodging-houses all over the interior, and I shall no more be obliged to carry about with me that miscellaneous lot of household furniture-bed, blankets, pots, kettles and frying pan, plates, dishes and wash-basin, coffeepots and coffee, tea, sugar and butter, salt, pickles, rice, bread and wine, pepper and curry powder, and half a hundred more odds and ends, the constant looking after which, packing and repacking, calculating and contriving, have been the standing plague of my life for the last seven years. You will better understand this when $I$ tell you that I have made in that time about eighty movements, averaging one a month, at every one of which all of these articles have had to be rearranged and repacked by myself according to the length of the trip, besides a constant personal supervision to prevent waste or destruction of stores in places where it is impossible to supply them.

Fanny wrote me last month to know about how I should like to live on my return. Of course, my dear mother, I should not think of living anywhere but with you, after such a long absence, if you feel yourself equal to housekeeping for us both; and I have always understood that your cottage would be large enough. The accommodation I should require is, besides a small bedroom, one large room, or a small one if there is, besides, a kind of lumber room where I could keep my cases and do rough and dirty work. I expect soon from Thomas a sketch-plan of your cottage, by which I can at once tell if it will do. If not, I must leave you and Fanny to arrange as you like about a new residence. I should prefer being a little way out of town in a quiet neighbourhood and with a garden, but near an omnibus route, and if necessary $I$ could lodge at any time for a week in London. This, I think, will be better and much cheaper than living close to town, and rents anywhere in the West End are sure now to rise 


\section{Early Letters}

owing to the approaching Great Exhibition. I must of course study economy, as the little money I have made will not be all got in for a year or two after my return. . . .

You must remember to write to me by the middle of November mail, as that is probably the last letter I can receive from you.

I send the letter to Fanny, who will most likely call on you and talk over matters. I am a little confused arriving in a new place with a great deal to do and living in a noisy hotel, so different to my usual solitary life, so that I cannot well collect my ideas to write any more, but must remain, my dear mother, your ever affectionate son,

ALFRED R. WALLACE.

\section{To His Sister, Mrs. Sims}

In the Mountains of Java. October 10, 1861.

My dear Fanny,-I have just received your second letter in praise of your new house. As I have said my say about it in my last, I shall now send you a few lines on other subjects.

I have been staying here a fortnight 4,000 feet above the sea in a fine cool climate, but it is unfortunately dreadfully wet and cloudy. I have just returned from a three days' excursion to one of the great Java volcanoes 10,000 feet high. I slept two nights in a house 7,500 feet above the sea. It was bitterly cold at night, as the hut was merely of plaited bamboo, like a sieve, so that the wind came in on all sides. I had flannel jackets and blankets and still was cold, and my poor men, with nothing but their usual thin cotton clothes, passed miserable nights lying on a mat on the ground round the fire which could only warm one side at a time. The highest peak is an extinct rolcano with the crater nearly filled up, forming merely a saucer on the 


\section{Alfred Russel Wallace}

top, in which is a good house built by the Government for the old Dutch naturalists who surveyed and explored the mountain. There are a lot of strawberries planted there, which do very well, but there were not many ripe. The common weeds and plants of the top were very like English ones, such as buttercups, sow-thistle, plantain, wormwood, chickweed, charlock, St. John's wort, violets and many others, all closely allied to our common plants of those names, but of distinct species. There was also a honey. suckle, and a tall and very pretty kind of cowslip. None of these are found in the low tropical lands, and most of them only on the tops of these high mountains. Mr. Darwin supposed them to have come there during a glacial or very cold period, when they could have spread over the tropics and, as the heat increased, gradually rose up the mountains. They were, as you may imagine, most interesting to me, and $I$ am very glad that $I$ have ascended one lofty mountain in the tropics, though I had miserable wet weather and had no view, owing to constant clouds and mist.

I also visited a semi-active volcano close by continually sending out steam with a noise like a blast-furnace-quite enough to give me a conception of all other descriptions of volcanoes.

The lower parts of the moutains of Java, from 3,000 to 6,000 feet, have the most beautiful tropical regetation $I$ have ever seen. Abundance of splendid tree ferns, some $50 \mathrm{ft}$. high, and some hundreds of varieties of other ferns, beautifulleaved plants as begonias, melastomas, and many others, and more flowers than are generally seen in the tropics. In fact, this region exhibits all the beauty the tropics can produce, but still I consider and will always maintain that our own meadows and woods and mountains are more beautiful. Our own weeds and wayside flowers are far 


\section{Early Letters}

prettier and more varied than those of the tropics. It is only the great leaves and the curious-looking plants, and the deep gloom of the forests and the mass of tangled vegetation that astonish and delight Europeans, and it is certainly grand and interesting and in a certain sense beautiful, but not the calm, sweet, warm beauty of our own fields, and there is none of the brightness of our own flowers; a field of buttercups, a hill of gorse or of heather, a bank of foxgloves and a hedge of wild roses and purple vetches surpass in beauty anything $I$ have ever seen in the tropics. This is a favourite subject with me, but I cannot go into it now.

Send the accompanying note to Mr. Stevens immediately. You will see what I say to him about my collections here. Java is the richest of all the islands in birds, but they are as well known as those of Europe, and it is almost impossible to get a new one. However, I am adding fine specimens to my collection, which will be altogether the finest known of the birds of the Archipelago, except perhaps that of the Leyden Museum, who have had naturalists collecting for them in all the chief islands for many years with unlimited means.

Give my kind love to mother, to whom I will write next time.-Your affectionate brother,

Alfred R. Wallace.

\section{To G. SILK ${ }^{1}$}

Singapore. January 20, 1862.

My dear George,- . . . On the question of marriage we probably differ much. I believe a good wife to be the greatest blessing a man can enjoy, and the only road to happiness, but the qualifications I should look for are probably not such as would satisfy you. My opinions have changed much on

1 For the other part of this letter see "My Life," i. 379. 


\section{Alfred Russel Wallace}

this point: I now look at intellectual companionship as quite a secondary matter, and should my good stars ever send me an affectionate, good-tempered and domestic wife, I shall care not one iota for accomplishments or even for education.

I cannot write more now. I do not yet know how long I shall be here, perhaps a month. Then ho! for England !-In haste, yours most affectionately,

Alfred R. WALlaCe. 


\section{PART II}

\section{I.-The Discovery of Natural Selection}

"There are not many joys in human life equal to the joy of the sudden birth of a generalisation, illuminating the mind after a long period of patient research. What has seemed for years so chaotic, so contradictory, and so problematic takes at once its proper position within an harmonious whole. Out of the wild confusion of facts and from behind the fog of guesses-contradicted almost as soon as they are born-a stately picture makes its appearance, like an Alpine chain suddenly emerging in all its grandeur from the mists which concealed it the moment before, glittering under the rays of the sun in all its simplicity and variety, in all its mightiness and beauty. And when the generalisation is put to a test, by applying it to hundreds of separate facts which seemed to be hopelessly contradictory the moment before, each of them assumes its due position, increasing the impressiveness of the picture, accentuating some characteristic outline, or adding an unsuspected detail full of meaning. The generalisation gains in strength and extent; its foundations grow in width and solidity; while in the distance, through the far-off mist on the horizon, the eye detects the outlines of new and still wider generalisations. He who has once in his life experienced this joy of scientific creation will never forget it; he will be longing to renew it; and he cannot but feel with pain that this sort of happiness is the lot of so few of us, while so many could also live through it-on a small or on a grand scale-if scientific methods and leisure were not limited to a handful of men."-Prince Kropotkin, "Memoirs of a Revolutionist."

THE social and scientific atmosphere in which Wallace found himself on his return from his eight years' exile in the Malay Archipelago was considerably more genial than that which he had enjoyed during his previous stay in London following his exploration of the Amazon. His position as one of the leading scientists of the day was already recognised, dating from the memorable 1st of July, 1858, when the two Papers, his own and Darwin's, on the theory of Natural Selection had been read before the Linnean Society.

During the four years which had elapsed since that date 


\section{Alfred Russel Wallace}

the storm of criticism had waxed and waned; subsiding for a time only to burst out afresh from some new quarter where the theory bade fair to jeopardise some ancient belief in which scientist or theologian had rested with comparative satisfaction until so rudely disturbed.

During this period Wallace had been quietly pursuing his researches in the Malay Archipelago, though not without a keen interest in all that was taking place at home in so far as this reached him by means of correspondence and newspaper reports-his only means of keeping in touch with the world beyond the bonndaries of the semicivilised countries in which he was then living.

In order to follow the story of how the conception of the theory of Natural Selection' grew and eventually took definite form in Wallace's mind, independently of the same development in the mind of Darwin, we must go back to a much earlier period in his life, and as nearly as possible link up the scattered remarks which here and there act as signposts pointing towards the supreme solution which has made his name famous for all time.

In Part I., Section I., many passages occur which clearly reveal his awakening to the study of nature. A chance remark overheard in conversation in the quiet street of Hertford touched the hidden spring of interest in a subject which was to become the one great purpose of his life. Then his enthusiastic yielding to the simple and natural attraction which flowers and trees have always exerted upon the sympathetic observer led step by step to the study of groups and families, until, on his second sojourn at Neath, and about a year before his journey to South America with H. W. Bates, we find him deliberately pondering over the problem which many years later he described by saying that he " had in fact been bitten by the passion for species and their description." 


\section{The Discovery of Natural Selection}

In a letter to Bates dated November 9th, 1847, he concludes by asking, "Have you read "Vestiges of the Natural History of Creation,' or is it out of your line ?" and in the next (dated December 28th), in reply to one from his friend, he continues, "I have a rather more favourable opinion of the 'Vestiges' than you appear to have. I do not consider it a hasty generalisation, but rather an ingenious hypothesis strongly supported by some striking facts and analogies, but which remains to be proved by more facts and the additional light which more research may throw upon the problem. . . It furnishes a subject for every observer of nature to attend to ; every fact," he observes, "will make either for or against it, and it thus serves both as an incitement to the collection of facts, and an object to which they can be applied when collected. Many eminent writers support the theory of the progressive development of animals and plants. There is a very philosophical work bearing directly on the questionLawrence's 'Lectures on Man.' . . . The great object of these 'Lectures' is to illustrate the different races of mankind, and the manner in which they probably originated, and he arrives at the conclusion (as also does Prichard in his work on the 'Physical History of Man') that the varieties of the human race have not been produced by any external causes, but are due to the development of certain distinctive peculiarities in some individuals which have thereafter become propagated through an entire race. Now, I should say that a permanent peculiarity not produced by external causes is a characteristic of 'species' and not of mere 'variety,' and thus, if the theory of the 'Vestiges' is accepted, the Negro, the Red Indian, and the European are distinct species of the genus Homo.

"An animal which differs from another by some decided and permanent character, however slight, which difference is undiminished by propagation and unchanged by climate and 


\section{Alfred Russel Wallace}

external circumstances, is universally held to be a distinct species; while one which is not regularly transmitted so as to form a distinct race, but is occasionally reproduced from the parent stock (like albinoes), is generally, if the difference is not very considerable, classed as a variety. But I would class both these as distinct species, and I would only consider those to be varieties whose differences are produced by external causes, and which, therefore, are not propagated as distinct races."

Again, writing about the same period, he adds : "I begin to feel rather dissatisfied with a mere local collection; little is to be learnt by it. I should like to take some one family to study thoroughly, principally with a view to the theory of the origin of species. By that means I am strongly of opinion that some definite results might be arrived at." And he further alludes to " $\mathrm{my}$ favourite subject-the variations, arrangements, distribution, etc., of species." 1

It is evident that in Bates Wallace found his first real friend and companion in matters scientific; for in another letter he says: "I quite envy you, who have friends near you attracted to the same pursuits. I know not a single person in this little town who studies any one branch of natural history, so that I am quite alone in this respect." In fact, except for a little friendly help now and then, as in the case of Mr. Hayward lending him a copy of Loudon's Encyclopedia of Plants, he had always pondered over his nature studies without any assistance up to the time of his meeting Bates at Leicester.

1 "My early letters to Bates suffice to show that the great problem of the origin of species was already distinctly formulated in my mind; that I was not satisfied with the more or less vague solutions at that time offered; that I believed the conception of evolution through natural law so clearly formulated in the "Vestiges' to be, so far as it went, a true one; and that I firmly believed that a full and careful study of the facts of nature would ultimately lead to a solution of the mystery."- " My Life," i. 254-7. 


\section{The Discovery of Natural Selection}

From the date of the above letter (1847) on to the early part of 1855-nearly eight years later-no reference is found either in his Life or correspondence to the one absorbing idea towards which all his reflective powers were being directed. Then, during a quiet time at Sarawak, the accumulation of thought and observation found expression in an essay entitled "The Law which has regulated the Introduction of Species," which appeared in the Annals and Magazine of Natural History in the following September (1855).

From November, 1854, the year of his arrival in the East, until January or February, 1856, Sarawak was the centre from which Wallace made his explorations inland, including some adventurous excursions on the Sadong River. During the wet season-or spring-of 1855, while living in a small house at the foot of the Santubong Mountains (with one Malay boy who acted as cook and general companion), he tells us how he occupied his time in looking over his books and pondering "over the problem which was rarely absent from [his] thoughts." In addition to the knowledge he had acquired from reading such books as those by Swainson and Humboldt, also Lucien Bonaparte's "Consuectus," and several catalogues of insects and reptiles in the British Museum "giving a mass of facts" as to the distribution of animals over the whole world, and having by his own efforts accumulated a vast store of information and facts direct from nature while in South America and since coming out East, he arrived at the conclusion that this "mass of facts" had never been properly utilised as an indication of the way in which species had come into existence. Having no fellow-traveller to whom he could confide these conclusions, he was almost driven to put his thoughts and ideas on paper-weighing each argument with studious care and open-eyed considera- 


\section{Alfred Russel Wallace}

tion as to its bearing on the whole theory. As the " result seemed to be of some importance," it was sent, as already mentioned, to the Annals and Magazine of Natural History as one of the leading scientific journals in England.

In the light of future events it is not surprising that Huxley (many years later), in referring to this " powerful essay," adds : " On reading it afresh I have been astonished to recollect how small was the impression it made."

As this earliest contribution by Wallace to the doctrine of Evolution ${ }^{1}$ is of peculiar historical value, and has not been so fully recognised as it undoubtedly deserves, and is now almost inaccessible, it will be useful to indicate in his own words the clear line of argument put forth by him two years before his second essay with which many readers are more familiar. He begins :

Every naturalist who has directed his attention to the subject of the geographical distribution of animals and plants must have been interested in the singular facts which it presents. Many of these facts are quite different from what would have been anticipated, and have hitherto been considered as highly curious but quite inexplicable. None of the explanations attempted from the time of Linnæus are now considered at all satisfactory; none of them have given a cause sufficient to account for the facts known at the time, or comprehensive enough to include all the new facts which have since been and are daily being added. Of late years, however, a great light has been thrown upon the subject by geological investigations, which have shown that the present state of the earth, and the organisms now inhabiting it, are but the last stage of a long and uninterrupted series of changes which it has undergone, and consequently, that to endeavour to explain and account for its present condition without any reference to those changes (as has frequently been done) must

1 "On the Law which has regulated the Introduction of Species."-Ann. and Mag. of Natural History, 2nd Series, 1855, xvi. 184. 


\section{The Discovery of Natural Selection}

lead to very imperfect and erroneous conclusions. . . . The following propositions in Organic Geography and Geology give the main facts on which the hypothesis [see p. 96] is founded.

\section{GEOGRAPHY}

(1) Large groups, such as classes and orders, are generally spread over the whole earth, while smailer ones, such as families and genera, are frequently confined to one portion, often to a very limited district.

(2) In widely distributed families the genera are often limited in range; in widely distributed genera, well-marked groups of species are peculiar to each geographical district.

(3) When a group is confined to one district and is rich in species, it is almost invariably the case that the most closely allied species are found in the same locality or in closely adjoining localities, and that therefore the natural sequence of the species by affinity is also geographical.

(4) In countries of a similar climate, but separated by a wide sea or lofty mountains, the families, genera and species of the one are often represented by closely allied families, genera and species peculiar to the other.

\section{Geology}

(5) The distribution of the organic world in time is very similar to its present distribution in space.

(6) Most of the larger and some of the smaller groups extend through several geological periods.

(7) In each period, however, there are peculiar groups, found nowhere else, and extending through one or several formations.

(8) Species of one genus, or genera of one family, occurring in the same geological time are more closely allied than those separated in time.

(9) As generally in geography no species or genus occurs in two very distant localities without being also found in intermediate places, so in geology the life of a species or genus has not been interrupted. In other words, no group or species has come into existence twice. 


\section{Alfred Russel Wallace}

(10) The following law may be deduced from these facts : Every species has come into existence coincident both in time and space with a pre-existing closely allied species.

This law agrees with, explains and illustrates all the facts connected with the following branches of the subject: 1st, the system of natural affinities; 2nd, the distribution of animals and plants in space; 3rd, the same in time, including all the phenomena of representative groups, and those which Prof. Forbes supposed to manifest polarity; 4th, the phenomena of rudimentary organs. We will briefly endeavour to show its bearing upon each of these.

If [this] law be true, it follows that the natural series of affinities will also represent the order in which the several species came into existence, each one having had for its immediate antetype a clearly allied species existing at the time of its origin. ... If two or more species have been independently formed on the plan of a common antetype, then the series of affinities will be compound, and can only be represented by a forked or many-branched line. . . . Sometimes the series of affinities can be well represented for a space by a direct progression from species to species or from group to group, but it is generally found impossible so to continue. There constantly occur two or more modifications of an organ or modifications of two distinct organs, leading us on to two distinct series of species, which at length differ so much from each other as to form distinct genera or families. These are the parallel series or representative groups of naturalists, and they often occur in different countries, or are found fossil in different formations. . . We thus see how difficult it is to determine in every case whether a given relation is an analogy or an affinity, for it is evident that as we go back along the parallel or divergent series, towards the common antetype, the analogy which existed between the two groups becomes an affinity. ... Again, if we consider that we have only the fragments of this vast system, the stems and main branches being represented by extinct species of which we have no knowledge, while a vast mass 


\section{The Discovery of Natural Selection}

of limbs and boughs and minute twigs and scattered leaves is what we have to place in order, and determine the true position each originally occupied with regard to the others, the whole difficulty of the true Natural System of classification becomes apparent to us.

We shall thus find ourselves obliged to reject all those systems of classification which arrange species or groups in circles, as well as those which fix a definite number for the division of each group. ... We have ... never been able to find a case in which the circle has been closed by a direct affinity. In most cases a palpable analogy has been substituted, in others the affinity is very obscure or altogether doubtful. . . .

If we now consider the geographical distribution of animals and plants upon the earth, we shall find all the facts beautifully in accordance with, and readily explained by, the present hypothesis. A country having species, genera, and whole families peculiar to it will be the necessary result of its having been isolated for a long period, sufficient for many series of species to have been created on the type of pre-existing ones, which, as well as many of the earlier-formed species, have become extinct, and made the groups appear isolated. . .

Such phenomena as are exhibited by the Galapagos Islands, which contain little groups of plants and animals peculiar to themselves, but most nearly allied to those of South America, have not hitherto received any, even a conjectural explanation. The Galapagos are a volcanic group of high antiquity and have probably never been more closely connected with the continent than they are at present.

He then proceeds at some length to explain how the Galapagos must have been at first "peopled . . . by the action of winds and currents," and that the modified prototypes remaining are the "new species" which have been "created in each on the plan of the pre-existing ones." This is followed by a graphic sketch of the general 


\section{Alfred Russel Wallace}

effect of volcanic and other action as affecting the distribution of species, and the exact form in which they are found, even fishes giving " evidence of a similar kind : each great river [having] its peculiar genera, and in more exten. sive genera its groups of closely allied species."

After stating a number of practical examples he continues :

The question forces itself upon every thinking mindWhy are these things so? They could not be as they are, had no law regulated their creation and dispersion. The law here enunciated not merely explains, but necessitates the facts we see to exist, while the vast and long-continued geological changes of the earth readily account for the exceptions and apparent discrepancies that here and there occur. The writer's object in putting forward his views in the present imperfect manner is to submit them to the tests of other minds, and to be made aware of all the facts supposed to be inconsistent with them. As his hypothesis is one which claims acceptance solely as explaining and connecting facts which exist in nature, he expects facts alone to be brought forward to disprove it, not a priori arguments against its probability.

He then refers to some of the geological "principles" expounded by Sir Charles Lyell on the "extinction of species," and follows this up by saying:

To discover how the extinct species have from time to time been replaced by new ones down to the very latest geological period, is the most difficult, and at the same time the most interesting, problem in the natural history of the earth. The present inquiry, which seeks to eliminate from known facts a law which has determined, to a certain degree, what species could and did appear at a given epoch, may, it is hoped, be considered as one step in the right direction towards a complete solution of it. ... Admitted facts seem to show ... a general, but not a detailed progression. . . . It is, however, by no means 


\section{The Discovery of Natural Selection}

difficult to show that a real progression in the scale of organisation is perfectly consistent with all the appearances, and even with apparent retrogression should such occur.

Using once more the analogy of a branching tree to illustrate the natural arrangement of species and their successive creation, he clearly shows how " apparent retrogression may be in reality a progress, though an inter. rupted one"; as "when some monarch of the forest loses a limb, it may be replaced by a feeble and sickly substitute." As an instance he mentions the Mollusca, which at an early period had reached a high state of development of forms and species, while in each succeeding age modified species and genera replaced the former ones which had become extinct, and "as we approach the present era but few and small representatives of the group remain, while the Gasteropods and Bivalves have acquired an immense preponderance." In the long series of changes the earth had undergone, the process of peopling it with organic beings had been continually going on, and whenever any of the higher groups had become nearly or quite extinct, the lower forms which better resisted the modified physical conditions served as the antetype on which to found new races. In this manner alone, it was believed, could the representative groups of successive periods, and the risings and fallings in the scale of organisations, be in every case explained.

Again, alluding to a recent article by Prof. Forbes, he points out certain inaccuracies and how they may be proved to be so; and continues:

We have no reason for believing that the number of species on the earth at any former period was much less than at present; at all events the aquatic portion, with 


\section{Alfred Russel Wallace}

which the geologists have most acquaintance, was probably often as great or greater. Now we know that there have been many complete changes of species, new sets of organisms have many times been introduced in place of old ones which have become extinct, so that the total amount which have existed on the earth from the earliest geological period must have borne about the same proportion to those now living as the whole human race who have lived and died upon the earth to the population at the present time. . . . Records of vast geological periods are entirely buried beneath the ocean ... beyond our reach. Most of the gaps in the geological series may thus be filled up, and vast numbers of unknown and unimaginable animals which might help to elucidate the affinities of the numerous isolated groups which are a perpetual puzzle to the zoologist may be buried there, till future revolutions may raise them in turn above the water, to afford materials for the study of whatever race of intelligent beings may then have succeeded us. These considerations must lead us to the conclusion that our knowledge of the whole series of the former inhabitants of the earth is necessarily most imperfect and fragmentary-as much as our knowledge of the present organic world would be, were we forced to make our collections and observations only in spots equally limited in area and in number with those actually laid open for the collection of fossils. . . The hypothesis of Prof. Forbes is essentially one that assumes to a great extent the completeness of our knowledge of the whole series of organic beings which have existed on earth. . . The hypothesis put forward in this paper depends in no degree upon the completeness of our knowledge of the former condition of the organic world, but takes what facts we have as fragments of a vast whole, and deduces from them something of the nature and proportion of that whole which we can never know in detail. . .

Another important series of facts, quite in accordance with, and even necessary deductions from, the law now developed, are those of rudimentary organs. That these really do exist, and in most cases have no special function 


\section{The Discovery of Natural Selection}

in the animal economy, is admitted by the first authorities in comparative anatomy. The minute limbs hidden beneath the skin in many of the snake-like lizards, the anal hooks of the boa constrictor, the complete series of jointed fingerbones in the paddle of the manatee and the whale, are a few of the most familiar instances. In botany a similar class of facts has been long recognised. Abortive stamens, rudimentary floral envelope and undeveloped carpels are of the most frequent occurrence. To every thoughtful naturalist the question must arise, What are these for ? What have they to do with the great laws of creation? Do they not teach us something of the system of nature? If each species has been created independently, and without any necessary relation with pre-existing species, what do these rudiments, these apparent imperfections, mean? There must be a cause for them; they must be the necessary result of some great natural law. Now, if ... the great law which has regulated the peopling of the earth with animal and vegetable life is, that every change shall be gradual; that no new creature shall be formed widely different from anything before existing; that in this, as in everything else in nature, there shall be gradation and harmony - then these rudimentary organs are necessary and are an essential part of the system of nature. Ere the higher vertebrates were formed, for instance, many steps were required, and many organs had to undergo modifications from the rudimental condition in which only they had as yet existed. . . . Many more of these modifications should we behold, and more complete series of them, had we a view of all the forms which have ceased to live. The great gaps that exist . . . would be softened down by intermediate groups, and the whole organic world would be seen to be an unbroken and harmonious system.

The article, in which we can see a great generalisation struggling to be born, ends thus :

It has now been shown, though most briefly and imperfectly, how the law that "every species has come into 


\section{Alfred Russel Wallace}

existence coincident both in time and space with a preexisting closely allied species," connects together and renders intelligible a vast number of independent and hitherto unexplained facts. The natural system of arrangement of organic beings, their geographical distribution, their geological sequence, the phenomena of representative and substituted groups in all their modifications, and the most singular peculiarities of anatomical structure, are all explained and illustrated by it, in perfect accordance with the vast mass of facts which the researches of modern naturalists have brought together, and, it is believed, not materially opposed to any of them. It also claims a superiority over previous hypotheses, on the ground that it not merely explains but necessitates what exists. Granted the law, and many of the most important facts in nature could not have been otherwise, but are almost as necessary deductions from it as are the elliptic orbits of the planets from the law of gravitation.

Some time after the appearance of this article, Wallace was informed by his friend and agent, Mr. Stevens, that several naturalists had expressed regret that he was "theorising," when what "was wanted was to collect more facts." Apart from this the only recognition which reached him in his remote solitude was a remark in an approving letter from Darwin (see p. 129).

As Wallace wrote nothing further of importance until the second essay which more fully disclosed his view of the origin of species, we will now briefly trace the growth of the theory of Natural Selection up to 1858, as it came to Darwin.

It is well known that during Darwin's voyage in the Beagle he was deeply impressed by discovering extinct armadillo-like fossil forms in South America, the home of armadilloes, and by observing the relationship of the plants and animals of each island in the Galapagos group to those 


\section{The Discovery of Natural Selection}

of the other islands and of South America, the nearest continent. These facts uggested evolution, and without evolution appeared to '; meaningless.

Evolution and its motive cause were the problems which " $r$ unted" him for the next twenty years. The first $s^{+}$, towards a possible solution was the " opening of $a r$, rebook for facts in relation to the origin of species" . 1837, two years before the publication of his Journal. From the very commencement of his literary and scientific work, a rule rigidly adhered to was that of interspersing his main line of thought and research by reading books touching on widely diverging subjects; and it was thus, no doubt, that during October, 1838, he read "for amusement" Malthus's "Essay on Population"; not, as he himself affirms, with any definite idea as to its intimate bearing on the subject so near his heart. But the immediate result was that the idea of Natural Selection at once arose in his mind, and, in his own words, he " had a theory. by which to work."

In May and June, 1842, during a visit to Maer and Shrewsbury, he wrote his first "pencil sketch of Species theory," but not until two years later (1844) did he ven. ture to enlarge this to one of 230 folio pages, "a wonderfully complete presentation of the arguments familiar to us in the 'Origin.' ",'

Already, in addition to the mass of facts collected, Darwin was busy with some of the experiments which he described in a letter to Sir Joseph Hooker (in 1855) as affording the latter a "good right to sneer, for they are so absurd, even in my opinion, that I dare not tell you." While a sentence in another letter (dated 1849) throws a sidelight on all this preparatory work: "In your letter you wonder what 'ornamental poultry' has to do with barnacles; but do

1 "Life of Charles Darwin" (one-vol. Edit.), p. 171. 


\section{Alfred Russel Wallace}

not flatter yourself that I shall not yet live to finish the barnacles, and then make a fool of myself on the subject of species, under which head ornamental poultry are very interesting."

Somewhere about this time (1842-44), Darwin, referring to the idea of Natural Selection which arose in his mind after reading Malthus on "Population" four years earlier, continues: "But at that time I overlooked one problem of great importance ... the tendency in organic beings descended from the same stock to diverge in character as they become modified ... and I can remember the very spot in the road, whilst in my carriage, when to my joy the solution occurred to me. . . The solution, as I believe, is that the modified offspring of all dominant and increasing forms tend to become adapted to many and highly diversified places in the economy of nature."1

So convinced was he of the truth of his ideas as expressed in the $1844 \mathrm{MS}$., that immediately after its completion he wrote the memorable letter to Mrs. Darwin telling her what he would wish done regarding its publication in the event of his death.

It was probably about two years later (1846) that he first confided his completed work-up to that date-to Sir Joseph Hooker, and later to Sir Charles Lyell; refraining, however, except in general conversation with other scientists, from informing anyone of the progress he was making towards a positive solution of the problem. His attitude of mind and manner at this period is happily illustrated by Huxley, who, speaking of his early acquaintance with Darwin, says : "I remember in the course of my first interview with Darwin expressing my belief in the sharpness of the line of demarcation between natural groups and in the absence of transitional forms, with all the con7 "Life of Charles Darwin," (one-vol. Edit.), p. 40, 


\section{The Discovery of Natural Selection}

fidence of youth and imperfect knowledge. I was not aware, at that time, that he had then been many years brooding over the Species question; and the humorous smile which accompanied his gentle answer, that $5^{\circ h}$ was not altogether his view, long haunted and puzzled me.

Little did Charles Darwin dream that, only three year. after this first MS. was written (in 1844), a youthful naturalist-known only as a surveyor at Neath-was deliberately pondering over the same issue, and writing to his only scientific friend on the subject. As, however, the different methods of thought by which they arrived at the same conclusion is so aptly related by Wallace himself, we will leave it for him to tell the story in its appointed place. ${ }^{1}$

In 1856, the year following the appearance of Wallace's essay in the Annals and Magazine of Natural History, both Hooker and Lyell urged Darwin to publish the result of his long and patient research. But he was still reluctant to do so, not having as yet satisfied himself with regard to certain conclusions which, he felt, must be stoutly maintained in face of the enormous amount of criticism which would arise immediately his theory was launched on the scientific world. And thus the event was postponed until the memorable year 1858 .

Up to the year 1856 no correspondence had passed between Wallace and Darwin, so far, at least, as the former could remember, for he says, in a letter dated Frith Hill, Godalming, December 3, 1887 (written to Mr. A. Newton) : "I had hardly heard of Darwin before going to the East, except as connected with the voyage of the Beagle. . . . I saw him once for a few minutes in the British Museum before I sailed. Through Stevens, my agent, I heard that he wanted curious varieties which he was studying. I think I wrote about some varieties of ducks I had sent,

1 See post, p. 112. 


\section{Alfred Russel Wallace}

and he must have written once to me. . . But at that time I had not the remotest notion that he had already arrived at a definite theory-still less that it was the same as occurred to me, suddenly, in Ternate in 1858." It is clear, therefore, that the essay written at Sarawak formed the first real link with Darwin, although not fully recognised at the time. In May, 1857, Darwin wrote to Wallace: "I am much obliged for your letter . . . and even still more by your paper in the Annals, a year or more ago. I can plainly see that we have thought much alike and to a certain extent have come to similar conclusions. ... I agree to almost every word of your paper; and I dare say that you will agree with me that it is very rare to find oneself agreeing pretty closely with any theoretical paper." He concludes: "You have my very sincere and cordial good wishes for success of all kinds, and may all your theories succeed, except that on Oceanic Islands, on which subject I will do battle to the death."

The three years from 1855 to 1858 were for Wallace crowded with hard work, and perilous voyages by sea and hardships by land. January, 1858, found him at Amboyna, where, in all probability, he found a pile of long-delayed correspondence awaiting him, and among this a letter from Bates referring to the article which had appeared in print September, 1855. In reply he says: "To persons who have not thought much on the subject I fear my paper on the 'Succession of Species' will not appear so clear as it does to you. That paper is, of course, merely the announcement of the theory, not its development. I have prepared the plan and written portions of a work embracing the whole subject, and have endeavoured to prove in detail what $I$ have as yet only indicated. . . I I have been much gratified by a letter from Darwin, in which he says 


\section{The Discovery of Natural Selection}

that he agrees with ' almost every word' of my paper. He is now preparing his great work on 'Species and Varieties,' for which he has been preparing materials for twenty years. He may save me the trouble of writing more on my hypothesis, by proving that there is no difference in nature between the origin of species and of varieties; or he may give me trouble by arriving at another conclusion; but, at all events, his facts will be given for me to work upon. Your collections and my own will furnish most valuable material to illustrate and prove the universal application of the hypothesis. The connection between the succession of affinities and the geographical distribution of a group, worked out species by species, has never yet been shown as we shall be able to show it."

"This letter proves," writes Wallace," "that at this time I had not the least idea of the nature of Darwin's proposed work nor of the definite conclusions he had arrived at, nor had I myself any expectations of a complete solution of the great problem to which my paper was merely the prelude. Yet less than two months later that solution flashed upon me, and to a large extent marked out a different line of work from that which $I$ had up to this time anticipated. ... In other parts of this letter I refer to the work I hoped to do myself in describing, cataloguing, and working out the distribution of my insects. I had in fact been bitten by the passion for species and their description, and if neither Darwin nor myself had hit upon 'Natural Selection,' I might have spent the best years of my life in this comparatively profitless work. But the new ideas swept all this away."

This letter was finished after his arrival at Ternate, and a few weeks later he was prostrated by a sharp attack of intermittent fever which obliged him to take a prolonged 


\section{Alfred Russel Wallace}

rest each day, owing to the exhausting hot and cold fits which rapidly succeeded one another.

The little bungalow at Ternate had now come to be regarded as "home" " for it was here that he stored all his treasured collections, besides making it the goal of all his wanderings in the Archipelago. One can understand, therefore, that, in spite of the fever, there was a sense of satisfaction in the feeling that he was surrounded with the trophies of his arduous labours as a naturalist, and this passion for species and their descriptions being an everpresent speculation in his mind, his very surroundings would unconsciously conduce towards the line of thought which brought to memory the argument of "positive checks" set forth by Malthus in his "Principles of Population" (read twelve years earlier) as applied to savage and civilised races. "It then," he says, " occurred to me that these causes or their equivalents are continually acting in the case of animals also; and as animals usually breed much more rapidly than does mankind, the destruction every year from these causes must be enormous in order to keep down the numbers of each species, since they evidently do not increase regularly from year to year, as otherwise the world would have been densely crowded with those that breed most quickly. . . . Then it suddenly flashed upon me that this self-acting process would necessarily $\mathrm{im}$ prove the race, because in every generation the inferior would inevitably be killed off and the superior would remain-that is, the fittest would survive. Then at once I seemed to see the whole effect of this, that when changes of land and sea, or of climate, or of food-supply, or of enemies occurredand we know that such changes have always been taking place-and considering the amount of individual variation that my experience as a collector had shown me to exist, then it followed that all the changes necessary. for the 


\section{The Discovery of Natural Selection}

adaptation of the species to the changing conditions would be brought about; and as great changes in the environment are always slow, there would be ample time for the change to be effected by the survival of the best fitted in every generation. In this way every part of an animal's organism could be modified as required, and in the very process of this modification the unmodified would die out, and thus the definite characters and the clear isolation of each new species would be explained. The more I thought over it the more I became convinced that I had at length found the long-sought-for law of nature that solved the problem of the origin of species. For the next hour I thought over the deficiencies in the theories of Lamarck and of the author of the 'Vestiges,' and I saw that my new theory supplemented these views and obviated every important difficulty. I waited anxiously for the termination of my fit (of fever) so that I might at once make notes for a paper on the subject. The same evening $I$ did this pretty fully, and on the two succeeding evenings wrote it out carefully in order to send it to Darwin by the next post, which would leave in a day or two.",

The story of the arrival of this letter at Down, and of the swift passage of events between the date on which Darwin received it and the reading of the " joint communica. tions" before the Linnean Society, has been often told. But few, perhaps, have enjoyed the privilege of reading the account of this memorable proceeding as related by Sir Joseph Hooker at the celebration of the event held by the Linnean Society in 1908.

As, therefore, the correspondence (pp. 127-320) between Wallace and Darwin during a long series of years conveys many expressions of their mutual appreciation of each other's work in connection with the origin of species, it

1 "My Life," 1. 361-3. 


\section{Alfred Russel Wallace}

will avoid a possible repetition of these if we take a long leap forward and give the notable speeches made by Wallace, Sir Joseph Hooker, Sir E. Ray Lankester, and others at this historical ceremony, which have not been published except in the Proceedings of the Society, now out of print.

The gathering was held on July 1, 1908, at the Institute of Civil Engineers, Great George Street, to celebrate the fiftieth anniversary of the joint communication made by Charles Darwin and Alfred Russel Wallace to the Linnean Society, "On the Tendency of Species to form Varieties; and on the Perpetuation of Varieties and Species by Natural Means of Selection." The large gathering included the President, Dr. Dukinfield H. Scott, distinguished representatives of many scientific Societies and Universities, the Danish and Swedish Ministers, and a representative from the German Embassy. Most of the members of Dr. Wallace's and Mr. Darwin's family. were also present. ${ }^{1}$ The President opened with some explanatory observations, and then invited Wallace to come forward in order to receive the first Darwin-Wallace Medal. In presenting it he said :

Dr. Alfred Russel Wallace,-We rejoice that we are so happy as to have with us to-day the survivor of the two great naturalists whose crowning work we are here to commemorate.

Your brilliant work in natural history and geography, and as one of the founders of the theory of Evolution by Natural Selection, is universally honoured and has often received public recognition, as in the awards of the Darwin and Royal Medals of the Royal Society, and of our Medal in 1892.

To-day, in asking you to accept the first DarwinWallace Medal, we are offering you of your own, for it is

1 It will be remembered, that Darwin died in April, 1882, twenty-six years previously. 


\section{The Discovery of Natural Selection}

you, equally with your great colleague, who created the occasion we celebrate.

There is nothing in the history of science more delightful or more noble than the story of the relations between yourself and Mr. Darwin, as told in the correspondence now so fully published-the story of a generous rivalry in which each discoverer strives to exalt the claims of the other. We know that Mr. Darwin wrote (April 6th, 1859): "You cannot tell how much I admire your spirit in the manner in which you have taken all that was done about publishing our papers. I had actually written a letter to you stating that I would not publish anything before you had published." Then came the letters of Hooker and Lyell, leading to the publication of the joint papers which they communicated.

You, on your side, always gave the credit to him, and underestimated your own position as the co-discoverer. I need only refer to your calling your great exposition of the joint theory "Darwinism," as the typical example of your generous emphasising of the claims of your illustrious fellow-worker.

It was a remarkable and momentous coincidence that both you and he should have independently arrived at the idea of Natural Selection after reading Malthus's book, and a most happy inspiration that you should have selected Mr. Darwin as the naturalist to whom to communicate your discovery. That theory, in spite of changes in the scientific fashion of the moment, you have always unflinchingly maintained, and still uphold as unshaken by all attacks.

Like Mr. Darwin, you, if I may say so, are above all a naturalist, a student and lover of living animals and plants, as shown in later years by your enthusiasm and success in gardening. It is to such men, those who have learnt the ways of Nature, as Nature really is in the open, to whom your doctrine of Natural Selection specially appeals, and therein lies its great and lasting strength.

Finally, you must allow me to allude to the generous interest you have always shown, and continue to show, 


\section{Alfred Russel Wallace}

in the careers of younger men who are endeavouring to follow in your steps.

I ask you, Dr. Wallace, to accept this Medal, struck in your honour and in that of the great work inaugurated fifty years ago by Mr. Darwin and yourself.

Wallace be ran his reply by thanking the Council of the Society for the honour they had done him, and then proceeded :

Since the death or 7arwin, in 1882, I have found myself in the somewhat unusual position of receiving credit and praise from popular writers under a complete misapprehension of what my share in Darwin's work really amounted to. It has been stated (not unfrequently) in the daily and weekly press, that Darwin and myself discovered " Natural Selection" simultaneously, while a more daring few have declared that I was the first to discover it, and I gave way to Darwin!

In order to avoid further errors of this kind (which this Celebration may possibly encourage), $I$ think it will be well to give the actual facts as simply and clearly as possible.

The one fact that connects me with Darwin, and which, I am happy to say, has never been doubted, is that the idea of what is now termed "natural selection" or "survival of the fittest," together with its far-reaching consequences, occurred to us independently, and was first jointly announced before this Society fifty years ago.

But, what is often forgotten by the Press and the public is, that the idea occurred to Darwin in 1838, nearly twenty years earlier than to myself (in February, 1858); and that during the whole of that twenty years he had been laboriously collecting evidence from the vast mass of literature of biology, of horticulture, and of agriculture; as well as himself carrying out ingenious experiments and original observations, the extent of which is indicated by the range of subjects discussed in his "Origin of Species," and especially in that wonderful storehouse of knowledge, his "Animals and Plants under Domestication," almost 


\section{The Discovery of Natural Selection}

the whole materials for which work had been collected, and to a large extent systematised, during that twenty years.

So far back as 1844, at a time when I had hardly thought of any serious study of nature, Darwin had written an outline of his views, which he communicated to his friends Sir Charles Lyell and Dr. (now Sir Joseph) Hooker. The former strongly urged him to publish an abstract of his theory as soon as possible, lest some other person might precede him; but he always refused till he had got together the whole of the materials for his intended great work. Then, at last, Lyell's prediction was fulfilled, and, without any apparent warning, my letter, with the enclosed essay, came upon him, like a thunderbolt from a cloudless sky! This forced him to what he considered a premature publicity, and his two friends undertook to have our two papers read before this Society.

How different from this long study and preparationthis philosophical caution-this determination not to make known his fruitful conception till he could back it up by overwhelming proofs-was my own conduct.

The idea came to me as it had come to Darwin, in a sudden flash of insight; it was thought out in a few hours -was written down with such a sketch of its various applications and developments as occurred to me at the moment-then copied on thin letter paper and sent off to Darwin-all within one week. $I$ was then (as often since) the "young man in a hurry": he, the painstaking and patient student seeking ever the full demonstration of the truth that he had discovered, rather than to achieve immediate personal fame.

Such being the actual facts of the case, I should have had no cause for complaint if the respective shares of Darwin and myself in regard to the elucidation of Nature's method of organic development had been henceforth estimated as being, roughly, proportional to the time we had each bestowed upon it when it was thus first given to the world-that is to say, as twenty years is to one week. For, he had already made it his own. If the persuasion of his friends had prevailed with 


\section{Alfred Russel Wallace}

him, and he had published his theory after ten years'-fifteen years' -or even eighteen years' elaboration of it $-I$ should have had no part in it whatever, and he would have been at once recognised as the sole and undisputed discoverer and patient investigator of this great law of "Natural Selection" in all its far-reaching consequences.

It was really a singular piece of good luck that gave to me any share whatever in the discovery. During the first half of the nineteenth century (and even earlier) many great biological thinkers and workers had been pondering over the problem and had even suggested ingenious but inadequate solutions. Some of these men were among the greatest intellects of our time, yet, till Darwin, all had failed; and it was only Darwin's extreme desire to perfect his work that allowed me to come in, as a very bad second, in the truly Olympian race in which all philosophical biologists, from Buffon and Erasmus Darwin to Richard Owen and Robert Chambers, were more or less actively engaged.

And this brings me to the very interesting question: Why did so many of the greatest intellects fail, while Darwin and myself hit upon the solution of this problem -a solution which this Celebration proves to have been (and still to be) a satisfying one to a large number of those best able to form a judgment on its merits? As I have found what seems to me a good and precise answer to this question, and one which is of some psychological interest, I will, with your permission, briefly state what it is.

On a careful consideration, we find a curious series of correspondences, both in mind and in environment, which led Darwin and myself, alone among our contemporaries, to reach identically the same theory.

First (and most important, as I believe), in early life both Darwin and myself became ardent beetle-hunters. Now there is certainly no group of organisms that so impresses the collector by the almost infinite number of its specific forms, the endless modifications of structure, shape, colour, and surface-markings that distinguish them from each other, and their innumerable adaptations to 


\section{The Discovery of Natural Selection}

diverse environments. These interesting features are exhibited almost as strikingly in temperate as in tropical regions, our own comparatively limited island-fauna possessing more than 3,000 species of this one order of insects.

Again, both Darwin and myself had what he terms "the mere passion for collecting," not that of studying the minutiæ of structure, either internal or external. I should describe it rather as an intense interest in the variety of living things-the variety that catches the eye of the observer even among those which are very much alike, but which are soon found to differ in several distinct characters.

Now it is this superficial and almost child-like interest in the outward forms of living things which, though often despised as unscientific, happened to be the only one which would lead us towards a solution of the problem of species. For Nature herself distinguishes her species by just such characters-often exclusively so, always in some degreevery small changes in outline, or in the proportions of appendages -as give a quite distinct and recognisable facies to each, often aided by slight peculiarities in motion or habit; while in a larger number of cases differences of surface-texture, of colour, or in the details of the same general scheme of colour-pattern or of shading, give an unmistakable individuality to closely allied species.

It is the constant search for and detection of these often unexpected differences between very similar creatures that gives such an intellectual charm and fascination to the mere collection of these insects; and when, as in the case of Darwin and myself, the collectors were of a speculative turn of mind, they were constantly led to think upon the "why" and the "how" of all this wonderful variety in naturethis overwhelming and, at first sight, purposeless wealth of specific forms among the very humblest forms of life.

Then, a little later (and with both of us almost accidentally) we became travellers, collectors, and observers, in some of the richest and most interesting portions of the earth; and we thus had forced upon our attention all the strange phenomena of local and geographical distribution, 


\section{Alfred Russel Wallace}

with the numerous problems to which they give risé. Thenceforward our interest in the great mystery of how species came into existence was intensified, and-again to use Darwin's expression-" haunted" us.

Finally, both Darwin and myself, at the critical period when our minds were freshly stored with a considerable body of personal observation and reflection bearing upon the problem to be solved, had our attention directed to the system of positive checks as expounded by Malthus in his "Principles of Population." The effect of that was analogous to that of friction upon the specially prepared match, producing that flash of insight which led us immediately to the simple but universal law of the "survival of the fittest," as the long-sought effective cause of the continuous modification and adaptations of living things.

It is an unimportant detail that Darwin read this book two years after his return from his voyage, while $I$ read it before I went abroad, and it was a sudden recollection of its teachings that caused the solution to flash upon me. I attach much importance, however, to the large amount of solitude we both enjoyed during our travels, which, at the most impressionable period of our lives, gave us ample time for reflection on the phenomena we were daily observing.

This view, of the combination of certain mental faculties and external conditions that led Darwin and myself to an identical conception, also serves to explain why none of our precursors or contemporaries hit upon what is really so very simple a solution of the great problem. Such evolutionists as Robert Chambers, Herbert Spencer, and Huxley, though of great intellect, wide knowledge, and immense power of work, had none of them the special turn of mind that makes the collector and the species-man; while they all-as well as the equally great thinker on similar lines, Sir Charles Lyell-became in early life immersed in different lines of research which engaged their chief attention.

Neither did the actual preeursors of Darwin in the statement of the principle-Wells, Matthews and Prichard - possess any adequate knowledge of the class of facts above referred to, or sufficient antecedent interest in the 


\section{The Discovery of Natural Selection}

problem itself, which were both needed in order to perceive the application of the principle to the mode of development of the varied forms of life.

And now, to recur to my own position, I may be allowed to make a final remark. I have long since come to see that no one deserves either praise or blame for the ideas that come to him, but only for the actions resulting therefrom. Ideas and beliefs are certainly not voluntary acts. They come to us-we hardly know how or whence, and once they have got possession of us we cannot reject or change them at will. It is for the common good that the promulgation of ideas should be free-uninfluenced either by praise or blame, reward or punishment.

But the actions which result from our ideas may properly be so treated, because it is only by patient thought and work that new ideas, if good and true, become adapted and utilised; while if untrue, or if not adequately presented to the world, they are rejected or forgotten.

I therefore accept the crowning honour you have conferred on me to-day, not for the happy chance through which I became an independent originator of the doctrine of "survival of the fittest," but as a too liberal recognition by you of the moderate amount of time and work I have given to explain and elucidate the theory, to point out some novel applications of it, and (I hope I may add) for my attempts to extend those applications, even in directions which somewhat diverged from those accepted by my honoured friend and teacher Charles Darwin.

Sir Joseph Hooker was now called upon by the President to receive the Darwin-Wallace Medal. In acknowledging the honour that had been paid him, he said :

No thesis or subject was vouchsafed to me by the Council, but, having gratefully accepted the honour, I was bound to find one for myself. It soon dawned upon me that the object sought by my selection might have been that, considering the intimate terms upon which Mr. Darwin extended to me his friendship, I could from 


\section{Alfred Russel Wallace}

my memory contribute to the knowledge of some important events in his career. It having been intimated to me that this was in a measure true, I have selected as such an event one germane to this Celebration and also engraven on my memory, namely, the considerations which determined Mr. Darwin to assent to the course which Sir Charles Lyell and myself had suggested to him, that of presenting to the Society, in one communication, his own and Mr. Wallace's theories on the effect of variation and the struggle for existence on the evolution of species.

You have all read Francis Darwin's fascinating work as editor of his father's "Life and Letters," where you will find (Vol. II., p. 116) a letter addressed, on the 18th of June, 1858, to Sir Charles Lyell by Mr. Darwin, who states that he had on that day received a communication from Mr. Wallace written from the Celebes Islands requesting that it might be sent to him (Sir Charles).

In a covering letter Mr. Darwin pointed out that the enclosure contained a sketch of a theory of Natural Selection as depending on the struggle for existence so identical with one he himself entertained and fully described in MS. in 1842 that he never saw a more striking coincidence : had Mr. Wallace seen his sketch he could not have made a better short abstract, even his terms standing " as heads of chapters." He goes on to say that he would at once write to Mr. Wallace offering to send his MS. to any journal; and concludes : "So my originality is smashed, though my book [the forthcoming 'Origin of Species'], if it will have any value will not be deteriorated, as all know the labour consists in the application of the theory."

After writing to Sir Charles Lyell, Mr. Darwin informed me of Mr. Wallace's letter and its enclosure, in a similar strain, only more explicitly announcing his resolve to abandon all claim to priority for his own sketch. I could not but protest against such a course, no doubt reminding him that I had read it and that Sir Charles knew its contents some years before the arrival of Mr. Wallace's letter; and that our withholding our knowledge of its priority would be unjustifiable. I further suggested the simultaneous pub- 


\section{The Discovery of Natural Selection}

lication of the two, and offered-should he agree to such a compromise-to write to $\mathrm{Mr}$. Wallace fully informing him of the motives of the course adopted.

In answer Mr. Darwin thanked me warmly for my offer to explain all to $\mathrm{Mr}$. Wallace, and in a later letter he informed me that he was disposed to look favourably on my suggested compromise, but that before making up his mind he desired a second opinion as to whether he could honourably claim priority, and that he proposed applying to Sir Charles Lyell for this. I need not say that this was a relief to me, knowing as I did what Sir Charles's answer must be.

In Vol. II., pp. 117-18, of the "Life and Letters," Mr. Darwin's application to Sir Charles Lyell is given, dated June 26th, with a postscript dated June 27th. In it he requests that the answer shall be sent to me to be forwarded to himself. I have no recollection of reading the answer, which is not to be found either in Darwin's or my own correspondence; it was no doubt satisfactory.

Further action was now left in the hands of Sir Charles and myself, we all agreeing that, whatever action was taken, the result should be offered for publication to the Linnean Society.

On June 29th Mr. Darwin wrote to me in acute distress, being himself very ill, and scarlet fever raging in the family, to which one infant son had succumbed on the previous day, and a daughter was ill with diphtheria. He acknowledged the receipt of the letter from me, adding, "I cannot think now of the subject, but soon will : you shall hear as soon as I can think" ; and on the night of the same day he writes again, telling me that he is quite prostrated and can do nothing but send certain papers for which $I$ had asked as essential for completing the prefatory statement to the communication to the Linnean Society of Mr. Wallace's essay. . . .

The communications were read, as was the custom in those days, by the Secretary to the Society. Mr. Darwin himself, owing to his illness and distress, could not be present. Sir Charles Lyell and myself said a few words to emphasise the importance of the subject, but, as recorded in the "Life and Letters" (Vol. II., p. 126), 


\section{Alfred Russel Wallace}

although intense interest was excited, no discussion took place: "the subject was too novel, too ominous, for the old school to enter the lists before armouring." . . .

It must also be noticed that for the detailed history given above there is no documentary evidence beyond what Francis Darwin has produced in the "Life and Letters." There are no letters from Lyell relating to it, not even answers to $\mathrm{Mr}$. Darwin's of the 18th, 25th, and 26th of June ; and Sir Leonard Lyell has at my request very kindly but vainly searched his uncle's correspondence for any relating to this subject beyond the two above mentioned. There are none of my letters to either Lyell or Darwin, nor other evidence of their having existed beyond the latter's acknowledgment of the receipt of some of them; and, most surprising of all, Mr. Wallace's letter and its enclosure have disappeared. Such is my recollection of this day, the fiftieth anniversary of which we are now celebrating, and of the fortnight that immediately preceded it.

It remains for me to ask your forgiveness for intruding upon your time and attention with the half-century-old real or fancied memories of a nonagenarian as contributions to the history of the most notable event in the annals of Biology that had followed the appearance in $\mathbf{1 7 3 5}$ of the "Systema Naturæ" of Linnæus.

Following Sir J. Hooker, the President, referring to Prof. Haeckel, who was unable to be present, said that he was "the great apostle of the Darwin-Wallace theory in Germany ... his enthusiastic and gallant advocacy [having] chiefly contributed to its success in that country. . . A man of world-wide reputation, the leader on the Continent of the ' Old Guard' of evolutionary biologists, Prof. Haeckel was one whom the Linnean Society delighted to honour." Two more German scientists were honoured with the Medal, namely Prof. August Weismann (who was also absent), and Prof. Eduard Strasburger, the latter paying a special tribute to Wallace in saying: "When I was young the investiga- 


\section{The Discovery of Natural Selection}

tions and the thought of Alfred Russel Wallace brought me a great stimulus. Through his 'Malay Archipelago' a new world of scientific knowledge was unfolded before me. On this occasion I feel it my duty to proclaim it with gratitude." The Medal was then presented to Sir Francis Galton, who delivered a notable speech in responding. The last on this occasion to receive the Medal was Sir E. Ray Lankester, who, in replying to the President's graceful speech, referred to the happy relationships which had existed between the contemporary men of science of his own time, but with special reference to Darwin and Wallace he said :

Never was there a more beautiful example of modesty, of unselfish admiration for another's work, of loyal deter. mination that the other should receive the full merit of his independent labours and thoughts, than was shown by Charles Darwin on that occasion.

Subsequently, throughout all their arduous work and varied publications upon the great doctrine which they on that day unfolded to humanity . . . the same complete absence of rivalry characterised these high-minded Englishmen, even when in some outcomes of their doctrine they were not in perfect agreement. . . I I think I am able to say that great as was the interest excited by the new doctrine in the scientific world, and wild and angry as was the opposition to it in some quarters, few, if any, who took part in the scenes attending the birth and earlier reception of Darwin's " Origin of Species" had a prevision of the enormous and all-important influence which that doctrine was destined to exercise upon every line of human thought. . . . It is in its application to the problems of human society that there still remains an enormous field of work and discovery for the DarwinWallace doctrine.

In the special branch of study which Wallace himself set going - the inquiry into the local variations, races, and species of insects as evidence of descent with modification, 


\section{Alfred Russel Wallace}

and of the mechanism by which that modification is brought about-there is still great work in progress, still an abundant field to be reaped. . . . Several able observers and experimenters have set themselves the task of improving, if possible, the theoretical structure raised by Darwin and Wallace. . . B But I venture to express the opinion that they have none of them resulted in any serious modification of the great doctrine submitted to the Linnean Society on July 1st, 1858, by Charles Darwin and Alfred Russel Wallace. Not only do the main lines of the theory of Darwin and Wallace remain unchanged, but the more it is challenged by new suggestions and new hypotheses the more brilliantly do the novelty, the importance, and the permanent value of the work by those great men, to-day commemorated by us, shine forth as the one great epochmaking effort of human thought on this subject.

Sir Francis Darwin and Sir William Thiselton-Dyer spoke on behalf of Schools which had sent representatives to the meeting; Prof. Lönnberg and Sir Archibald Geikie on behalf of the Academies and Societies; while Lord Avebury delivered the concluding address.

Any summary of this period in the lives of Darwin and Wallace would be incomplete without some distinct reference to one other name, namely, that of Herbert Spencer, whom I have linked with them in the Introduction.

While we owe to Darwin and Wallace a definite theory of organic development, it must be remembered that Spencer included this in the general scheme of Evolution which grew as slowly but surely in his mind-and as independently as did that of the origin of species in the minds of Darwin and Wallace. Huxley recalls: "Within the ranks of biologists, at that time, I met with nobody except Dr. Grant, of University College, who had a word to say for Evolution-and his advocacy was not calculated to advance the cause. Outside these ranks, the only person known to 


\section{The Discovery of Natural Selection}

me whose knowledge and capacity compelled respect, and who was, at the same time, a thorough-going evolutionist, was Mr. Herbert Spencer. . . Many and prolonged were the battles we fought on this topic. . . I I took my stand upon two grounds : first, that up to that time the evidence in favour of transmutation was wholly insufficient; and, secondly, that no suggestions respecting the causes of the transmutations assumed .. . were in any way adequate to explain the phenomena. Looking back at the state of knowledge at that time, I really do not see that any other conclusion was justifiable." "

And Prof. Raphael Meldola, in a lecture on Evolution wherein he compares the impression left by each of these great founders of that school upon the current of modern thought, says: “Through all ... his [Spencer's] writings the underlying idea of development can be traced with increasing depth and breadth, expanding in 1850 in his ' Social Statics' to a foreshadowing of the general doctrine of Evolution. In 1852 his views on organic evolution had become so definite that he gave public expression to them in that wellknown and powerful essay on 'The Development Hypothesis.' . . . In the 'Principles of Psychology,' the first edition of which was published in 1855, the evolutionary principle was dominant. By 1858-the year of the announcement of Natural Selection by Darwin and Wallace -he had conceived the great general scheme and had sketched out the first draft of the prospectus of the Synthetic Philosophy, the final and amended syllabus [being] issued in 1860. The work of Darwin and Spencer from that period, although moving along independent lines, was directed towards the same end, notwithstanding the diversity of materials which they made use of and the differences in their methods of attack; that end was 1 "Life and Letters of Charles Darwin," ii. 188. 


\section{Alfred Russel Wallace}

the establishment of Evolution as a great natural principle or law."

In this connection it is especially interesting to note how near Spencer had come to the conception of Natural Selection without grasping its full significance. In an article on a "Theory of Population" (published in the Westminster Review for April, 1852) he wrote: "And here, indeed, without further illustration, it will be seen that premature death, under all its forms and from all its causes, cannot fail to work in the same direction. For as those prematurely carried off must, in the average of cases, be those in whom the power of self-preservation is the least, it unavoidably follows that those left behind to continue the race must be those in whom the power of self-preservation is the greatest-must be the select of their generation. So that whether the dangers of existence be of the kind produced by excess of fertility, or of any other kind, it is clear that by the ceaseless exercise of the faculties needed to contend with them, and by the death of all men who fail to contend with them successfully, there is ensured a constant progress towards a higher degree of skill, intelligence, self-regulation-a better co-ordinance of actions-a more complete life."

Up to the period of the publication of the "Origin of Species" and the first conception of the scheme of the Synthetic Philosophy there had been no communication between Darwin and Spencer beyond the presentation by Spencer of a copy of his Essays to Darwin in 1858, which was duly acknowledged. But by the time the "Origin of Species" had been before the public for eight years, the Darwinian principle of selection had become an integral part of the Spencerian mechanism of organic evo-

" The Herbert Spencer Lecture," delivered at the Museum, December 8, 1910. (Glarendon Press, Oxford.) 


\section{The Discovery of Natural Selection}

lution. Indeed the term "survival of the fittest," approved by both Darwin and Wallace as an alternative for " natural selection," was, as is well known, introduced by Spencer.

Wallace's relations with Spencer, though somewhat controversial at times, were nevertheless cordial and sympathetic. In "My Life" he tells of his first visit, and the impression left upon his mind by their conversation. It occurred somewhere about 1862-3, shortly after he and Bates had read, and been greatly impressed by, Spencer's "First Principles." "Our thoughts," he says, "were full of the great unsolved problem of the origin of lifea problem which Darwin's 'Origin of Species' left in as much obscurity as ever-and we looked to Spencer as the one man living who could give us some clue to it. His wonderful exposition of the fundamental laws and conditions, actions and interactions of the material universe seemed to penetrate so deeply into that 'nature of things' after which the early philosophers searched in vain ... that we hoped he would throw some light on that great problem of problems. . . He was very pleasant, spoke appreciatively of what we had both done for the practical exposition of evolution, and hoped we would continue to work at the subject. But when we touched upon the great problem, and whether he had arrived at even one of the first steps towards its solution, our hopes were dashed at once. That, he said, was too fundamental a problem to even think of solving at present. We did not yet know enough of matter in its essential constitution nor of the various forces of nature; and all he could say was that everything pointed to its having been a development out of matter-a phase of that continuous process of evolution by which the whole universe had been brought to its present condition. And so we had to wait and work contentedly at minor problems. And now, after forty years, though 


\section{Alfred Russel Wallace}

Spencer and Darwin and Weismann have thrown floods of light on the phenomena of life, its essential nature and its origin remain as great a mystery as ever. Whatever light we do possess is from a source which Spencer and Darwin neglected or ignored.",

In his presidential address to the Entomological Society in 1872 Wallace made some special allusion to Spencer's theory of the origin of instincts, and on receiving a copy of the address Spencer wrote: "It is gratifying to me to find that your extended knowledge does not lead you to scepticism respecting the speculation of mine which you quote, but rather enables you to cite further facts in justification of it. Possibly your exposition will lead some of those, in whose lines of investigation the question lies, to give deliberate attention to it." A further proof of his confidence was shown by asking Wallace (in 1874) to look over the proofs of the first six chapters of his "Principles of Sociology" in order that he might have the benefit of his criticisms alike as naturalist, anthropologist, and traveller.

This brief reference to the illustrious group of men to whom we owe the foundations of this new epoch of evolutionary thought-and not the foundations only, but also the patient building up of the structure upon which each one continued to perform his allotted task-and the prefatory notes and the footnotes attached to the letters will serve to elucidate the historical correspondence between Darwin and Wallace which follows.

$$
1 \text { "My Life," ii. 23-4. }
$$




\title{
PART II (Continued)
}

\section{II.-The Complete Extant Correspondence between Wallace and Darwin}

\author{
[1857-81]
}

"I hope it is a satisfaction to you to reflect-and very few things in my life have been more satisfactory to me-that we have never felt any jealousy towards each other, though in some senses rivals. I believe I can say this of myself with truth, and I am absolutely sure that it is true of you."-DARwiN to Wallace.

"To have thus inspired and retained this friendly feeling, notwithstanding our many differences of opinion, I feel to be one of the greatest honours of my life."-Wallace to Darwin.

"I think the way he [Wallace] carries on controversy is perfectly beautiful, and in future histories of science the Wallace-Darwin episode will form one of the few bright points among rival claimants."-ERAsmus Darwis to his niece, Henrietta Darwin, 1871.

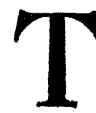

HE first eight letters from Darwin to Wallace were found amongst the latter's papers, carefully preserved in an envelope on the outside of which he had written the words reproduced on the next page. Neither Wallace's part of this correspondence, nor the original MS. of his essay " On the Tendency of Varieties to Depart Indefinitely from the Original Type," which he sent to Darwin from Ternate, has been discovered. But these eight letters from Darwin explain themselves and reveal the inner story of the independent discovery of the theory of Natural Selection.

With respect to the letters which follow the first eight, both sides of the correspondence, with few exceptions, have been brought together. Some of the letters have already appeared in "The Life and Letters of Charles Darwin" and "More Letters," others in "My Life," by A. R. Wallace, whilst many have not before been published.

Some of these letters, in themselves, have little more than ephemeral interest, and parts of other letters could have been 
The furs 8 letters I received from Darwin (wile mi the Anally Aschefrelago)

B. The hins. of my Paper ecus to. Dannie and fricitied ni the formal ot the Lisinean Society, was wish

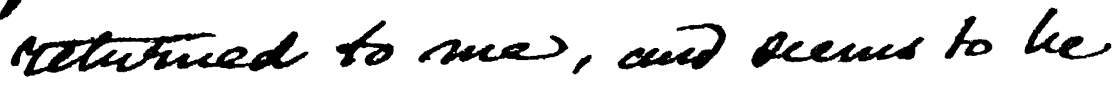
lost. The kronos wet t th i Ines: wee perkafis reach to $\varphi_{\text {i }}$ Charles Lyell, 'on the Yecratany of the Lime. Soc. $\alpha$ may voice day ko found. It was written an thin foreign note paper.

Aprodtrallace

FACSIMILE OF INSCRIPTION BY WALLACE ON THE ENVELOPE IN WHICH HE KEPT THE FIRST EIGHT LETTERS HE RECEIVED FROM DARWIN.

128 


\section{The Wallace-Darwin Correspondence}

eliminated, from the point of view of lightening this volume and of economising the reader's attention. But I decided, with the fullest approval of the Wallace and Darwin families, that the letters of these illustrious correspondents should be here presented as a whole, without mutilation.

Many of the notes of explanation to the Wallace letters have been gathered from his own writings, and are mainly in his own words, and in such cases the reader has the advantage of perusing letters annotated by their author, while most of the notes to the Darwin letters are by Sir F. Darwin.

\section{LETTER I \\ C. Darwin to A. R. Wallace \\ Down, Bromley, Kent. May 1, 1857.}

My dear Sir,-I am much obliged for your letter of Oct. 10th from Celebes, received a few days ago: in a laborious undertaking, sympathy is a valuable and real encouragement. By your letter, and even still more by your paper in the Annals, ${ }^{2}$ a year or more ago, I can plainly see that we have thought much alike and to a certain extent have come to similar conclusions. In regard to the paper in the Annals, I agree to the truth of almost every word of your paper; and I daresay that you will agree with me that it is very rare to find oneself agreeing pretty closely with any theoretical paper; for it is lamentable how each man draws his own different conclusions from the very same fact. This summer will make the twentieth year (!) since I opened my first note-book on the question how and in what way do species and varieties differ from each other. I am now preparing my work for publication, but I find the subject so very large, that though I have written

1 "On the Law which has regulated the Introduction of New Species." Ann. and Mag. of Nat. Hist., 1855. The law is thus stated by Wallace: " Every species has come into existence coincident both in time and space with a pre-existing closely-allied species." 


\section{Alfred Russel Wallace}

many chapters, I do not suppose I shall go to press for two years.

I have never heard how long you intend staying in the Malay Archipelago; I wish I might profit by the publication of your Travels there before my work appears, for no doubt you will reap a large harvest of facts.

I have acted already in accordance with your advice of keeping domestic varieties, and those appearing in a state of nature, distinct; but I have sometimes doubted of the wisdom of this, and therefore $I$ am glad to be backed by your opinion. I must confess, however, I rather doubt the truth of the now very prevalent doctrine of all our domestic animals having descended from several wild stocks; though I do not doubt that it is so in some cases. I think there is rather better evidence on the sterility of hybrid animals than you seem to admit: and in regard to plants, the collection of carefully recorded facts by Kölreuter and Gaertner (and Herbert) is enormous. I most entirely agree with you on the little effect of "climatic conditions" which one sees referred to ad nauseam in all books: I suppose some very little effect must be attributed to such influences, but I fully believe that they are very slight. It is really im. possible to explain my views in the compass of a letter as to causes and means of variation in a state of nature; but I have slowly adopted a distinct and tangible idea-whether true or false others must judge; for the firmest conviction of the truth of a doctrine by its author seems, alas, not to be the slightest guarantee of truth.

I have been rather disappointed at my results in the poultry line; but if you should, after receiving this, stumble on any curious domestic breed, I should be very glad to have it; but I can plainly see that the result will not be at all worth the trouble which I have taken. The case is different with the domestic pigeons; from its study I have learned 


\section{The Wallace-Darwin Correspondence}

much. The Rajah has sent me some of his pigeons and fowls and cats' skins from the interior of Borneo and from Singapore. Can you tell me positively that black jaguars or leopards are believed generally or always to pair with black? I do not think colour of offspring good evidence. Is the case of parrots fed on fat of fish turning colour mentioned in your Travels? I remember a case of parrots with (I think) poison from some toad put into hollow whence primaries had been removed.

One of the subjects on which I have been experimenting, and which cost me much trouble, is the means of distribution of all organic beings found on oceanic islands; and any facts on this subject would be most gratefully received.

Land-molluscs are a great perplexity to me. This is a very dull letter, but I am a good deal out of health, and am writing this, not from my home, as dated, but from a water-cure establishment.

With most sincere good wishes for your success in every way, I remain, my dear Sir, yours sincerely,

Ch. Darwin.

\section{LETTER II}

\section{Darwin to A. R. Wallace}

Down, Bromley, Kent. December 22, 1857.

My dear Sir,-I thank you for your letter of Sept. 27th. I am extremely glad to hear that you are attending to distribution in accordance with theoretical ideas. I am a firm believer that without speculation there is no good and original observation. Few travellers have attended to such points as you are now at work on; and indeed the whole subject of distribution of animals is dreadfully behind that of plants. You say that you have been somewhat 


\section{Alfred Russel Wallace}

surprised at no notice having been taken of your paper in the Annals. I cannot say that I am ; for so very few naturalists care for anything beyond the mere description of species. But you must not suppose that your paper has not been attended to: two very good men, Sir C. Lyell, and Mr. E. Blyth at Calcutta, specially called my attention to it. Though agreeing with you on your conclusions in the paper, I believe I go much further than you; but it is too long a subject to enter on my speculative notions. I have not yet seen your paper on distribution of animals in the Aru Islands : I shall read it with the utmost interest; for I think that the most interesting quarter of the whole globe in respect to distribution; and I have long been very imperfectly trying to collect data from the Malay Archipelago. I shall be quite prepared to subscribe to your doctrine of subsidence : indeed from the quite independent evidence of the coral reefs I coloured my original map in my Coral volumes colours [sic] of the Aru Islands as one of subsidence, but got frightened and left it uncoloured. But I can see that you are inclined to go much further than $I$ am in regard to the former connection of oceanic islands with continents. Ever since poor E. Forbes propounded this doctrine, it has been eagerly followed; and Hooker elaborately discusses the former connection of all the Antarctic islands and New Zealand and South America. About a year ago I discussed the subject much with Lyell and Hooker (for I shall have to treat of it) and wrote out my arguments in opposition; but you will be glad to hear that neither Lyell nor Hooker thought much of my arguments; nevertheless, for once in my life I dare withstand the almost preternatural sagacity of Lyell. You ask about land-shells on islands far distant from continents : Madeira has a few identical with those of Europe, and here the evidence is really good, as some of them are sub-fossil. In the Pacific 


\section{The Wallace-Darwin Correspondence}

islands there are cases of identity, which I cannot at present persuade myself to account for by introduction through man's agency; although Dr. Aug. Gould has conclusively shown that many land-shells have thus been distributed over the Pacific by man's agency. These cases of introduction are most plaguing. Have you not found it so in the Malay Archipelago? It has seemed to me, in the lists of mammals of Timor and other islands, that several in all probability have been naturalised.

Since writing before, I have experimented a little on some land-molluscs, and have found sea-water not quite so deadly as I anticipated. You ask whether I shall discuss Man : I think I shall avoid the whole subject, as so surrounded with prejudices, though $I$ fully admit that it is the highest and most interesting problem for the naturalist. My work, on which I have now been at work more or less for twenty years, will not fix or settle anything; but I hope it will aid by giving a large collection of facts with one definite end. I get on very slowly, partly from ill-health, partly from being a very slow worker. I have got about half written; but I do not suppose I shall publish under a couple of years. I have now been three whole months on one chapter on hybridism !

I am astonished to see that you expect to remain out three or four years more: what a wonderful deal you will have seen; and what an interesting area, the grand Malay Archipelago and the richest parts of South America! I infinitely admire and honour your zeal and courage in the good cause of natural science; and you have my very sincere and cordial good wishes for success of all kinds ; and may all your theories succeed, except that on oceanic islands, on which subject I will do battle to the death.-Pray believe me, my dear Sir, yours very sincerely,

C. Darwin. 


\title{
Alfred Russel Wallace
}

\author{
LETTER III \\ C. Darwin to A. R. Wallace \\ Down, Bromley, Kent. January 25, 1859.
}

My dear Sir,-I was extremely much pleased at receiving three days ago your letter to me and that to Dr. Hooker. Permit me to say how heartily I admire the spirit in which they are written. Though I had absolutely nothing whatever to do in leading Lyell and Hooker to what they thought a fair course of action, yet I naturally could not but feel anxious to hear what your impression would be. I owe indirectly much to you and them; for I almost think that Lyell would have proved right and I should never have completed my larger work, for I have found my abstract ${ }^{1}$ hard enough with my poor health; but now, thank God, I am in my last chapter but one. My abstract will make a small volume of 400 or 500 pages. Whenever published, I will of course send you a copy, and then you will see what I mean about the part which I believe selection has played with domestic productions. It is a very different part, as you suppose, from that played by " natural selection."

I sent off, by same address as this note, a copy of the Journal of the Linnean Society, and subsequently I have sent some half-dozen copies of the Paper. I have many other copies at your disposal; and I sent two to your friend Dr. Davies (?), author of works on men's skulls.

I am glad to hear that you have been attending to birds' nests; I have done so, though almost exclusively under one point of view, viz. to show that instincts vary, so that selection could work on and improve them.

1 "The Origin of Species." 


\section{The Wallace-Darwin Correspondence}

Few other instincts, so to speak, can be preserved in a museum.

Many thanks for your offer to look after horses' stripes; if there are any donkeys', pray add them.

I am delighted to hear that you have collected bees' combs; when next in London $I$ will inquire of $F$. Smith and Mr. Saunders. This is an especial hobby of mine, and I think I can throw light on the subject. If you can collect duplicates at no very great expense, I should be glad of specimens for myself, with some bees of each kind. Young growing and irregular combs, and those which have not had pupæ, are most valuable for measurements and examination; their edges should be well protected against abrasion.

Everyone whom I have seen has thought your paper very well written and interesting. It puts my extracts (written in 1839, now just twenty years ago!), which I must say in apology were never for an instant intended for publication, in the shade.

You ask about Lyell's frame of mind. I think he is somewhat staggered, but does not give in, and speaks with horror often to me of what a thing it would be and what a job it would be for the next edition of the Principles if he were "perverted." But he is most candid and honest, and I think will end by being perverted. Dr. Hooker has become almost as heterodox as you or I-and I look at Hooker as $b y$ far the most capable judge in Europe.

Most cordially do I wish you health and entire success in all your pursuits; and God knows, if admirable zeal and energy deserve success, most amply do you deserve it. I look at my own career as nearly run out; if I can publish my abstract, and perhaps my greater work on the same subject, I shall look at my course as done.-Believe me, my dear Sir, yours very sincerely,

C. Darwin. 


\title{
Alfred Russel Wallace
}

\author{
LETTER IV \\ C. Darwin to A. R. Wallace
}

Down, Bromley, Kent. April 6, 1859.

My dear Mr. Wallace,-I this morning received your pleasant and friendly note of Nov. 30th. The first part of my MS. ${ }^{1}$ is in Murray's hands, to see if he likes to publish it. There is no Preface, but a short Introduction, which must be read by everyone who reads my book. The second paragraph in the Introduction ${ }^{2}$ I have had copied verbatim from my foul copy, and you will, I hope, think that I have fairly noticed your papers in the Linnean Transactions. ${ }^{3}$ You must remember that I am now publishing only an Abstract, and I give no references. I shall of course allude to your paper on Distribution $;^{4}$ and I have added that I know from correspondence that your explanation of your law is the same as that which $I$ offer. You are right, that I came to the conclusion that Selection was the principle of change from study of domesticated productions; and then reading Malthus I saw at once how to apply this principle. Geographical distribution and geographical relations of extinct to recent inhabitants of South America first led me to the subject. Especially the case of the Galapagos Islands.

I hope to go to press in early part of next month. It will be a small volume of about 500 pages or so. I will, of course, send you a copy.

I forget whether I told you that Hooker, who is our

1 "The Origin of Species."

2 First Edit., 1859, pp. 1, 2.

3 "On the Tendency of Species to form Varieties and on the Perpetuation of Varieties and Species by Natural Means of Selection." By C. Darwin and A. R. Wallace. Communicated by Sir C. Lyell and J. D. Hooker. Journ. Linn. Soc., 1859, iii. 45. Read July 1st, 1858.

" "On the Law which has regulated the Introduction of New Species." Ann. and Mag. of Nat. Hist., 1855, xvi. 184. 


\section{The Wallace-Darwin Correspondence}

best British botanist, and perhaps the best in the world, is a full convert, and is now going immediately to publish his confession of faith; and I expect daily to see the proof-sheets. Huxley is changed and believes in mutation of species: whether a convert to us, I do not quite know. We shall live to see all the younger men converts. My neighbour and excellent naturalist, $J$. Lubbock, is an enthusiastic convert. I see by Natural History notices that you are doing great work in the Archipelago; and most heartily do I sympathise with you. For God's sake take care of your health. There have been few such noble labourers in the cause of natural science as you are. Farewell, with every good wish.-Yours sincerely,

C. Darwin.

P.S.-You cannot tell how I admire your spirit, in the manner in which you have taken all that was done about publishing our papers. I had actually written a letter to you, stating that I would not publish anything before you had published. I had not sent that letter to the post when I received one from Lyell and Hooker, urging me to send some MS. to them, and allow them to act as they thought fair and honourably to both of us. I did so.

\section{LeTTter V}

\section{G. Darwin to A. R. Wallace}

Down, Bromley, Kent. August 9, 1859.

My dear Mr. Wallace,-I received your letter and memoir ${ }^{1}$ on the 7 th, and will forward it to-morrow to the Linnean Society. But you will be aware that there is no meeting till beginning of November. Your paper seems to me admir. able in matter, style and reasoning; and I thank you for

1 This seems to refer to Wallace's paper on "The Zoological Geography of the Malay Archipelago," Journ. Linn. Soc., 1860. 


\section{Alfred Russel Wallace}

allowing me to read it. Had I read it some months ago I should have profited by it for my forthcoming volume. But my two chapters on this subject are in type; and though not yet corrected, I am so wearied out and weak in health that I am fully resolved not to add one word, and merely improve style. So you will see that my views are nearly the same with yours, and you may rely on it that not one word shall be altered owing to my having read your ideas. Are you aware that Mr. W. Earl published several years ago the view of distribution of animals in the Malay Archipelago in relation to the depth of the sea between the islands? I was much struck with this, and have been in habit of noting all facts on distribution in the Archipelago and elsewhere in this relation. I have been led to conclude that there has been a good deal of naturalisation in the different Malay islands, and which I have thought to certain extent would account for anomalies. Timor has been 'my greatest puzzle. What do you say to the peculiar Felis there? I wish that you had visited Timor: it has been asserted that a fossil mastodon or elephant's tooth (I forget which) had been found there, which would be a grand fact. I was aware that Celebes was very peculiar; but the relation to Africa is quite new to me and marvellous, and almost passes belief. It is as anomalous as the relation of plants in South-West Australia to the Cape of Good Hope.

I differ wholly from you on colonisation of oceanic islands, but you will have everyone else on your side. I quite agree with respect to all islands not situated far in ocean. I quite agree on little occasional internavigation between lands when once pretty well stocked with inhabitants, but think this does not apply to rising and ill-stocked islands.

Are you aware that annually birds are blown to Madeira, to Azores (and to Bermuda from America). I wish I had given fuller abstract of my reasons for not believing in 138 


\section{The Wallace-Darwin Correspondence}

Forbes's great continental extensions; but it is too late, for I will alter nothing. I am worn out, and must have rest.

Owen, I do not doubt, will bitterly oppose us; but I regard that very little, as he is a poor reasoner and deeply considers the good opinion of the world, especially the aristocratic world.

Hooker is publishing a grand Introduction to the Flora of Australia, and goes the whole length. I have seen proofs of about half.-With every good wish, believe me yours very sincerely,

C. DARWIN.

Excuse this brief note, but I am far from well.

\section{LETTER VI}

\section{Darwin to A. R. Wallace}

Ilkley. November 13, 1859.

My dear Sir,-I have told Murray to send you by post (if possible) a copy of my book, and I hope that you will receive it at nearly the same time with this note. (N.B.I have got a bad finger, which makes me write extra badly.) If you are so inclined, I should very much like to hear your general impression of the book, as you have thought so profoundly on the subject and in so nearly the same channel with myself. I hope there will be some little new to you, but I fear not much. Remember, it is only an abstract, and very much condensed. God knows what the public will think. No one has read it, except Lyell, with whom I have had much correspondence. Hooker thinks him a complete convert, but he does not seem so in his letters to me. But he is evidently deeply interested in the subject. I do not think your share in the theory will be overlooked by the real judges, as Hooker, Lyell, Asa Gray, etc.

I have heard from Mr. Sclater that your paper on the 139 


\section{Alfred Russel Wallace}

Malay Archipelago has been read at the Linnean Society, and that he was extremely much interested by it.

I have not seen one naturalist for six or nine months owing to the state of my health, and therefore I really have no news to tell you. I am writing this at Ilkley Wells, where I have been with my family for the last six weeks, and shall stay for some few weeks longer. As yet I have profited very little. God knows when I shall have strength for my bigger book.

I sincerely hope that you keep your health: I suppose that you will be thinking of returning soon with your magnificent collection and still grander mental materials. You will be puzzled how to publish. The Royal Society Fund will be worth your consideration.-With every good wish, pray believe me yours very sincerely,

Charles Darwin.

I think that I told you before that Hooker is a complete convert. If I can convert Huxley I shall be content.

\section{LETTER VII}

\section{Dartin to A. R. Wallace}

Down, Bromley, Kent, S.E. March 7, 1860.

My dear Wallace,-The addresses which you have sent me are capital, especially that to the Rajah; and I have dispatched two sets of queries. I now enclose a copy to you, and should be very glad of any answers; you must not suppose the P.S. about memory has lately been inserted; please return these queries, as it is my standard copy. The subject is a curious one; I fancy I shall make a rather interesting appendix to my Essay on Man.

I fully admit the probability of "protective adaptation" having come into play with female butterflies as well as with female birds. I have a good many facts which 


\section{The Wallace-Darwin Correspondence}

make me believe in sexual selection as applied to man, but whether I shall convince anyone else is very doubtful.Dear Wallace, yours very sincerely,

Ch. DaRWIN.

\section{LETTER VIII}

\section{Darwin to A. R. Wallace}

Down, Bromley, Kent. $\quad$ May 18, 1860.

My dear Mr. Wallace,-I received this morning your letter from Amboyna dated Feb. 16th, containing some remarks and your too high approbation of my book. Your letter has pleased me very much, and I most completely agree with you on the parts which are strongest and which are weakest. The imperfection of the geological record is, as you say, the weakest of all; but yet $I$ am pleased to find that there are almost more geological converts than of pursuers of other branches of natural science. I may mention Lyell, Ramsay, Jukes, Rogers, Keyerling, all good men and true. Pictet of Geneva is not a convert, but is evidently staggered (as I think is Bronn of Heidelberg), and he has written a perfectly fair review in the Bib. Universelle of Geneva. Old Bronn has translated my book, well done also into German, and his well-known name will give it circulation. I think geologists are more converted than simple naturalists because more accustomed to reasoning.

Before telling you about the progress of opinion on the subject, you must let me say how I admire the generous manner in which you speak of my book: most persons would in your position have felt bitter envy and jealousy. How nobly free you seem to be of this common failing of mankind. But you speak far too modestly of yourself; you would, if you had had my leisure, have done the work just as well, perhaps better, than I have done it. Talking of envy, you never read anything more envious and spiteful 


\section{Alfred Russel Wallace}

(with numerous misrepresentations) than Owen is in the Edinburgh Review. I must give one instance; he throws doubts and sneers at my saying that the ovigerous frena of cirripedes have been converted into branchiæ, because $I$ have not found them to be branchiæ; whereas he himself admits, before I wrote on cirripedes, without the least hesitation, that their organs are branchiæ. The attacks have been heary and incessant of late. Sedgwick and Prof. Clarke attacked me savagely at the Cambridge Philosophical Society, but Henslow defended me well, though not a convert. Phillips has since attacked me in a lecture at Cambridge; Sir W. Jardine in the Edinburgh New Philosophical Journal, Wollaston in the Annals of Nat. History, A. Murray before the Royal Soc. of Edinburgh, Haughton at the Geological Society of Dublin, Dawson in the Canadian Nat. Magazine, and many others. But I am getting casehardened, and all these attacks will make me only more determinedly fight. Agassiz sends me personal civil messages, but incessantly attacks me; but Asa Gray fights like a hero in defence. Lyell keeps as firm as a tower, and this autumn will publish on the Geological History of Man, and will then declare his conversion, which now is universally known. I hope that you have received Hooker's splendid essay. So far is bigotry carried that $I$ can name three botanists who will not even read Hooker's essay!! Here is a curious thing: a Mr. Pat. Matthews, a Scotchman, published in 1830 a work on Naval Timber and Arboriculture, and in the appendix to this he gives most clearly but very briefly in half-dozen paragraphs our view of Natural Selection. It is a most complete case of anticipation. He published extracts in the Gardeners' Chronicle. I got the book, and have since published a letter acknowledging that $I$ am fairly forestalled. Yesterday $I$ heard from Lyell that a German, Dr. Schaffhausen, has sent him a 


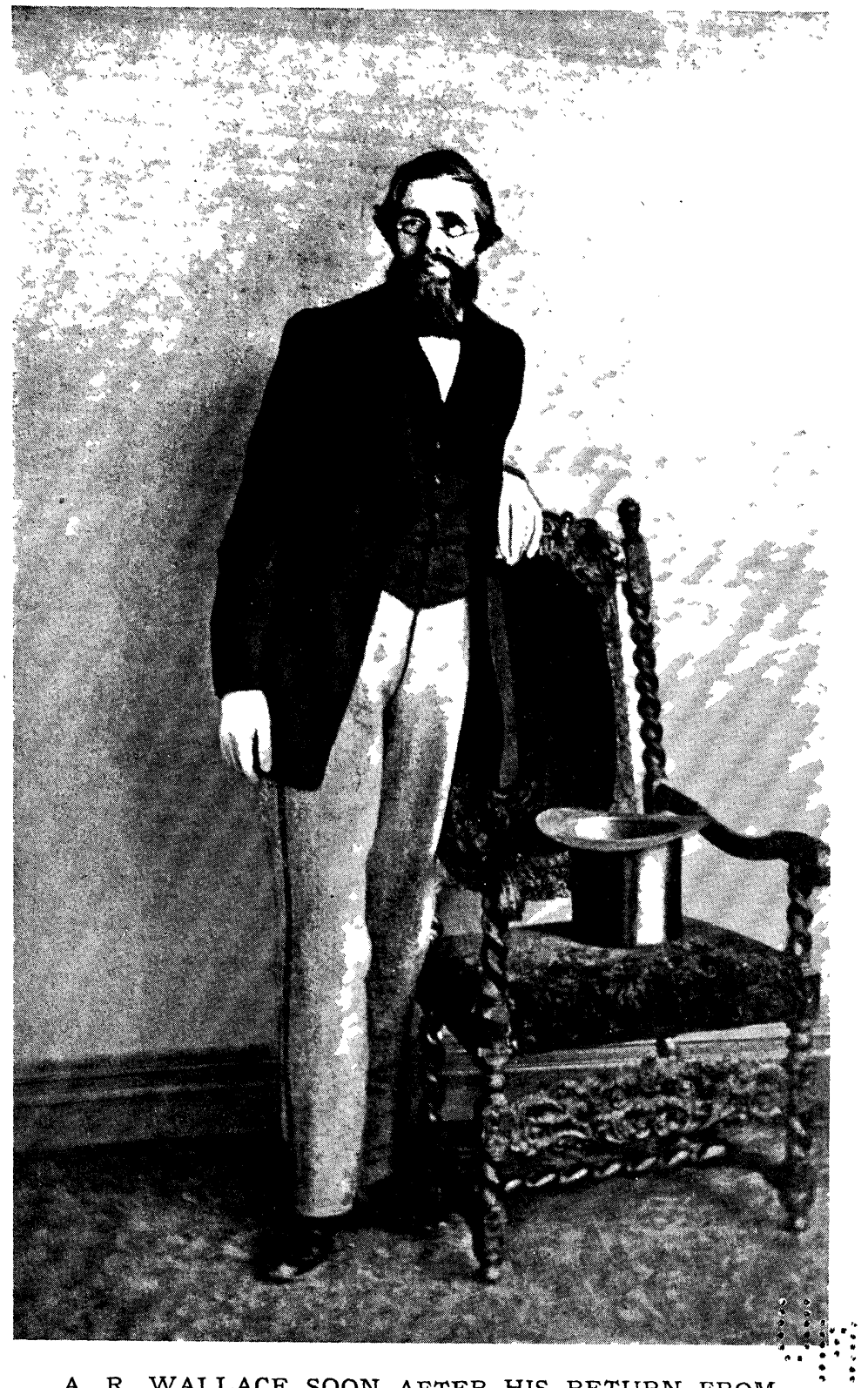

A. R. WALLACE SOON AFTER HIS RETURN FROM

THE EAST 
$\vdots \vdots \vdots \vdots \vdots$ 


\section{The Wallace-Darwin Correspondence}

pamphlet published some years ago, in which the same view is nearly anticipated, but I have not yet seen this pamphlet. My brother, who is a very sagacious man, always said, "You will find that someone will have been before you." I am at work at my larger work, which I shall publish in separate volumes. But for ill-health and swarms of letters I get on very, very slowly. I hope that I shall not have wearied you with these details.

With sincere thanks for your letter, and with most deeply-felt wishes for your success in science and in every way, believe me your sincere well-wisher,

C. DaRwin.

Of the letters from Wallace to Darwin which have been preserved, the earliest is the following :

5 Westbourne Grove Terrace, W. April 7, 1862.

My dear Mr. Darwin,-I was much pleased to receive your note this morning. I have not yet begun work, but hope to be soon busy. As I am being doctored a little I do not think I shall be able to accept your kind invitation at present, but trust to be able to do so during the summer.

I beg you to accept a wild honeycomb from the island of Timor, not quite perfect but the best I could get. It is of a small size, but of characteristic form, and I think will be interesting to you. I was quite unable to get the honey out of it, so fear you will find it somewhat in a mess; but no doubt you will know how to clean it. I have told Stevens to send it to you.

Hoping your health is now quite restored and with best wishes, I remain, my dear Mr. Darwin, yours very sincerely,

AlfRed R. Wallace.

5 Westbourne Grove Terrace, W. May 23, 1862.

My dear Mr. Darwin,-Many thanks for your most interesting book on the Orchids. I have read it through most 


\section{Alfred Russel Wallace}

attentively, and have really been quite as much staggered by the wonderful adaptations you show to exist in them as by the Eye in animals or any other complicated organs. I long to get into the country and have a look at some orchids guided by your new lights, but $I$ have been now for ten days confined to my room with what is disagreeable though far from dangerous-boils.

I have been reading several of the Reviews on the "Origin," and it seems to me that you have assisted those who want to criticise you by your overstating the difficulties and objections. Several of them quote your own words as the strongest arguments against you.

I think you told me Owen wrote the article in the Quarterly. This seems to me hardly credible, as he speaks so much of Owen, quotes him as such a great authority, and I believe even calls him a profound philosopher, etc. etc. Would Owen thus speak of himself ?

Trusting your health is good, I remain, my dear Mr. Darwin, yours very faithfully,

Alfred R. WALlace.

Down, Bromley, Kent, S.E. May 24, 1862.

My dear Mr. Wallace,-I write one line to thank you for your note and to say that the Bishop of Oxford $^{1}$ wrote the Quarterly Review (paid $£ 60$ ), aided by Owen. In the Edinburgh Owen no doubt praised himself. Mr. Maw's Review in the Zoologist is one of the best, and staggered me in parts, for I did not see the sophistry of parts. I could lend you any which you might wish to see; but you would soon be tired. Hopkins and Pictet in France are two of the best.

I am glad you approve of my little Orchid book; but it has not been worth, I fear, the ten months it has cost me : it was a hobby-horse, and so beguiled me.

I am sorry to hear that you are suffering from boils; I

${ }^{1}$ Dr. Samuel Wilberforce. 


\section{The Wallace-Darwin Correspondence}

have often had fearful crops: I hope that the doctors are right in saying that they are serviceable.

How puzzled you must be to know what to begin at. You will do grand work, I do not doubt.

My health is, and always will be, very poor: I am that miserable animal a regular valetudinarian.-Yours very sincerely,

C. DaRwin.

5 Westbourne Grove Terrace, W. August 8, 1862.

My dear Mr. Darwin,-I sincerely trust that your little boy is by this time convalescent, and that you are therefore enabled to follow your favourite investigations with a more tranquil mind.

I heard a remark the other day which may not perhaps be new to you, but seemed to me a fact, if true, in your favour. Mr. Ward (I think it was), a member of the Microscopical Society, mentioned as a fact noticed by himself with much surprise that "the muscular fibres of the whale were no larger than those of the bee!"-an excellent indication of community of origin.

While looking at the ostriches the other day at the Gardens, it occurred to me that they were a case of special difficulty, as, inhabiting an ancient continent, surrounded by numerous enemies, how did their wings ever become abortive, and if they did so before the birds had attained their present gigantic size, strength and speed, how could they in the transition have maintained their existence? I see Westwood in the Annals brings forward the same case, arguing that the ostriches should have acquired better wings within the historic period; but as they are now the swiftest of animals they evidently do not want their wings, which in their present state may serve some other trifling purpose in their economy such as fans, or balancers, which may have prevented their being reduced to such rudiments as in the $\mathbf{K}$ 


\section{Alfred Russel Wallace}

cassowaries. The difficulty to me seems to be, how, if they once had flight, could they have lost it, surrounded by swift and powerful carnivora against whom it must have been the only defence?

This probably is all clear to you, but $I$ think it is a point you might touch upon, as I think the objection will seem a strong one to most people.

In a day or two I go to Devonshire for a few weeks and hope to lay in a stock of health to enable me to stick to work at my collections during the winter. I begin to find that large collections involve a heavy amount of manual labour which is not very agreeable.

Present my compliments to Mrs. and Miss Darwin, and believe me yours very faithfully,

Alfred R. Wallace.

1 Carlton Terrace, Southampton. August 20, 1862.

My dear Mr. Wallace,-You will not be surprised that $I$ have been slow in answering when I tell you that my poor boy $^{1}$ became frightfully worse after you were at Down; and that during our journey to Bournemouth he had a slight relapse here and my wife took the scarlet fever rather severely. She is over the crisis. I have had a horrid time of it, and God only knows when we shall be all safe at home again-half my family are at Bournemouth.

I have given a piece of the comb from Timor to a Mr. Woodbury (who is working at the subject), and he is extremely interested by it (I was sure the specimen would be valuable) and has requested me to ascertain whether the bee (A. testacea) is domesticated when it makes its combs. Will you kindly inform me?

Your remarks on ostriches have interested me, and I have alluded to the case in the Third Edition. The difficulty does not seem to me so great as to you. Think of bustards, which 


\section{The Wallace-Darwin Correspondence}

inhabit wide open plains, and which so seldom take flight: a very little increase in size of body would make them incapable of flight. The idea of ostriches acquiring flight is worthy of Westwood; think of the food required in these inhabitants of the desert to work the pectoral muscles! In the rhea the wings seem of considerable service in the first start and in turning. ${ }^{1}$...

5 Westbourne Grove Terrace, W. September 30, 1862.

My dear Mr. Darwin,-Many thanks for the third edition of the "Origin," which I found here on my return from Devonshire on Saturday. I have not had time yet to read more than the Historical Sketch, which is very interesting, and shows that the time had quite come for your book.

I am now reading Herbert Spencer's " First Principles," which seems to me a truly great work, which goes to the root of everything.

I hope you will be well enough to come to Cambridge.

I remain, my dear Mr. Darwin, yours very faithfully,

Alfred R. Wallace.

5 Westbourne Grove Terrace, W. January 14 [1863 ?].

My dear Mr. Darwin,-I am very sorry indeed to hear you are still in weak health. Have you ever tried mountain air? A residence at 2,000 or $3,000 \mathrm{ft}$. elevation is very invigorating.

I trust your family are now all in good health, and that you may be spared any anxiety on that score for some time. If you come to town I shall hope to have the pleasure of seeing you.

I am now in much better health, but find sudden changes of weather affect me very much, bringing on ague and fever fits. I am now working a little, but having fresh collections

1 The last sheet of the letter is missing. 


\section{Alfred Russel Wallace}

still arriving from correspondents in the East, it is principally the drudgery of cleaning, packing, and arrangement.

On the opposite page $I$ give all the information $I$ can about the Timor fossils, so that you can send it entire to Dr. Falconer.

With best wishes for the speedy recovery of your health, I remain, my dear Mr. Darwin, yours very faithfully,

\section{Alfred R. WALlace.}

Down, Bromley, Kent, S.E. January 1, 1864.

Dear Wallace,-I am still unable to write otherwise than by dictation. In a letter received two or three weeks ago from Asa Gray he writes :"I read lately with gusto Wallace's exposé of the Dublin man on Bee cells, etc."'

Now though I cannot read at present, I much want to know where this is published, that I may procure a copy. Further on Asa Gray says (after speaking of Agassiz's paper on Glaciers in the Atlantic Magazine and his recent book entitled "Method of Study"): "Pray set Wallace upon these articles." So Asa Gray seems to think much of your powers of reviewing, and I mention this as it assuredly is laudari a laudato.

I hope you are hard at work, and if you are inclined to tell me I should much like to know what you are doing.

It will be many months, I fear, before I shall do anything. Pray believe me yours very sincerely, CH. Darwin.

5 Westbourne Grove Terrace, W. January 2, 1864.

My dear Darwin,-Many thanks for your kind letter. I was afraid to write because $I$ heard such sad accounts of your health, but I am glad to find that you can write, and

1 Wallace's paper was entitled. "Remarks on the Rev. S. Haughton's Paper on the Bee's Cells and on the Origin of Species." Prof. Haughton's paper appeared in the Ann. and Mag. of Nat. Hist., 1863, xi. 415. Wallace's was published in the same journal. 


\section{The Wallace-Darwin Correspondence}

I presume read, by deputy. My little article on Haughton's paper was published in the Annals of Natural History about August or September last, I think, but I have not a copy to refer to. I am sure it does not deserve Asa Gray's praises, for though the matter may be true enough, the manner I know is very inferior. It was written hastily, and when I read it in the Annals I was rather ashamed of it, as I knew so many could have done it so much better.

I will try and see Agassiz's paper and book. What I have hitherto seen of his on Glacial subjects seems very good, but in all his Natural History theories, he seems so utterly wrong and so totally blind to the plainest deduction from facts, and at the same time so vague and obscure in his language, that it would be a very long and wearisome task to answer him.

With regard to work, I am doing but little-I am afraid I have no good habit of systematic work. I have been gradually getting parts of my collections in order, but the obscurities of synonymy and descriptions, the difficulty of examining specimens, and my very limited library, make it wearisome work.

I have been lately getting the first groups of my butterflies in order, and they offer some most interesting facts in variation and distribution-in variation some very puzzling ones. Though I have very fine series of specimens, I find in many cases $I$ want more; in fact if $I$ could have afforded to have all my collections kept till my return I should, I think, have found it necessary to retain twice as many as I now have.

I am at last making a beginning of a small book on my Eastern journey, which, if I can persevere, I hope to have ready by next Christmas. I am a very bad hand at writing anything like narrative. I want something to argue on, and then I find it much easier to go ahead. I rather despair, therefore, of making so good a book as Bates's, though I 


\section{Alfred Russel Wallace}

think my subject is better. Like every other traveller, I suppose, I feel dreadfully the want of copious notes on conmon everyday objects, sights and sounds and incidents, which I imagined I could never forget but which I now find it impossible to recall with any accuracy.

I have just had a long and most interesting letter from my old companion Spruce. He says he has had a letter from you about Melastoma, but has not, he says, for three years seen a single melastomaceous plant! They are totally absent from the Pacific plains of tropical America, though so abundant on the Eastern plains. Poor fellow, he seems to be in a worse state than you are. Life has been a burden to him for three years owing to lung and heart disease, and rheumatism, brought on by exposure in high, hot, and cold damp valleys of the Andes. He went down to the dry climate of the Pacific coast to die more at ease, but the change improved him, and he thinks to come home, though he is sure he will not survive the first winter in England. He had never been able to get a copy of your book, though I am sure no one would have enjoyed or appreciated it more.

If you are able to bear reading, will you allow me to take the liberty of recommending you a book? The fact is I have been so astonished and delighted with the perusal of Spencer's works that I think it a duty to society to recommend them to all my friends who I think can appreciate them. The one I particularly refer to now is "Social Statics," a book which is by no means hard to read; it is even amusing, and owing to the wonderful clearness of its style may be read and understood by anyone. I think, therefore, as it is quite distinct from your special studies at present, you might consider it as "light literature," and I am pretty sure it would interest you more than a great deal of what is now considered very good. I am utterly astonished that so few people seem to read Spencer, and the utter ignorance 


\section{The Wallace-Darwin Correspondence}

there seems to be among politicians and political economists of the grand views and logical stability of his works. He appears to me as far ahead of John Stuart Mill as J. S. M. is of the rest of the world, and, I may add, as Darwin is of Agassiz. The range of his knowledge is no less than its accuracy. His nebular hypothesis in the last volume of his essays is the most masterly astronomical paper I have ever read, and in his forthcoming volume on Biology he is I understand going to show that there is something else besides Natural Selection at work in nature. So you must look out for a "foeman worthy of your steel"! But perhaps all this time you have read his books. If so, excuse me, and pray give me your opinion of him, as I have hitherto only met with one man (Huxley) who has read and appreciated him.

Allow me to say in conclusion how much $I$ regret that unavoidable circumstances have caused me to see so little of you since my return home, and how earnestly I pray for the speedy restoration of your health.-Yours most sincerely,

ALFRed R. WALLACE.

Malvern Wells. Tuesday, March, 1864.

My dear Mr. Wallace,-Your kindness is neverfailing. I got worse and worse at home and was sick every day for two months ; so came here, when I suddenly broke down and could do nothing; but I hope I am now very slowly recovering, but am very weak.

Sincere thanks about Melastoma: these flowers have baffled me, and I have caused several friends much useless labour; though, Heaven knows, I have thrown away time enough on them myself.

The gorse case is very valuable, and I will quote it, as I presume I may.

I was very glad to see in the Reader that you have been 151 


\section{Alfred Russel Wallace}

giving a grand paper (as I infer from remarks in discussion) on Geographical Distribution.

I am very weak, so will say no more.-Yours very sincerely,

C. Darwin.

In Vol. I., p. 93, of the "Life and Letters of Charles Darwin," Darwin states the circumstances which led to his writing the "Descent of Man." He says that his collection of facts, begun in 1837 or 1838 , was continued for many years without any definite idea of publishing on the subject. The letter to Wallace of May 28, 1864, in reply to the latter's of May 10, shows that in the period of illhealth and depression about 1864 he despaired of ever being able to do so.

5 Westbourne Grove Terrace, W. May 10, 1864.

My dear Darwin,-I was very much gratified to hear by your letter of a month back that you were a little better, and I have since heard occasionally through Huxley and Lubbock that you are not worse. I sincerely hope the summer weather and repose may do you real good.

The Borneo Cave exploration is to go on at present without a subscription. The new British consul who is going out to Sarawak this month will undertake to explore some of the caves nearest the town, and if anything of interest is obtained a good large sum can no doubt be raised for a thorough exploration of the whole country. Sir J. Brooke will give every assistance, and will supply men for the preliminary work.

I send you now my little contribution to the theory of the origin of man. I hope you will be able to agree with me. If you are able, I shall be glad to have your criticisms.

I was led to the subject by the necessity of explaining the vast mental and cranial differences between man and the apes combined with such small structural differences in other parts of the body, and also by an endeavour to account for the diversity of human races combined with 


\section{The Wallace-Darwin Correspondence}

man's almost perfect stability of form during all historical epochs.

It has given me a settled opinion on these subjects, if nobody can show a fallacy in the argument.

The Anthropologicals did not seem to appreciate it much, but we had a long discussion which appears almost verbatim in the Anthropological Review. ${ }^{1}$

As the Linnean Transactions will not be out till the end of the year I sent a pretty full abstract of the more interesting parts of my Papilionidæ paper ${ }^{2}$ to the Reader, which, as you say, is a splendid paper.

Trusting Mrs. Darwin and all your family are well, and that you are improving, believe me yours most sincerely,

AlfRed R. Wallace.

Down, Bromley, Kent. $\quad$ May 28, 1864.

Dear Wallace,-I am so much better that I have just finished a paper for the Linnean Society; but as I am not yet at all strong $I$ felt much disinclination to write, and therefore you must forgive me for not having sooner thanked you for your paper on Man received on the 11th. But first let me say that I have hardly ever in my life been more struck by any paper than that on variation, etc. etc., in the Reader. I feel sure that such papers will do more for the spreading of our views on the modification of species than any separate treatises on the single subject itself. It is really admirable; but you ought not in the Man paper to speak of the theory as mine; it is just as much yours as mine. One correspondent has already noticed to me your "high-minded" conduct on this head.

1 For March, 1864.

2 Reader, April 16,1864. An abstract of Wallace's paper " On the Phenomena of Variation and Geographical Distribution, as illustrated by the Papilionidæ of the Malayan Region," Linn. Soc. Trans., xxv. 


\section{Alfred Russel Wallace}

But now for your Man paper, about which I should like to write more than $I$ can. The great leading idea is quite new to me, viz. that during late ages the mind will have been modified more than the body; yet I had got as far as to see with you that the struggle between the races of man depended entirely on intellectual and moral qualities. The latter part of the paper I can designate only as grand and most eloquently done. I have shown your paper to two or three persons who have been here, and they have been equally struck with it.

I am not sure that I go with you on all minor points. When reading Sir G. Grey's account of the constant battles of Australian savages, I remember thinking that Natural Selection would come in, and likewise with the Esquimaux, with whom the art of fishing and managing canoes is said to be hereditary. I rather differ on the rank under the classificatory point of view which you assign to Man : I do not think any character simply in excess ought ever to be used for the higher division. Ants would not be separated from other hymenopterous insects, however high the instinct of the one and however low the instincts of the other.

With respect to the differences of race, a conjecture has occurred to me that much may be due to the correlation of complexion (and consequently hair) with constitution. Assume that a dusky individual best escaped miasma and you will readily see what I mean. I persuaded the Director-General of the Medical Department of the Army to send printed forms to the surgeons of all regiments in tropical countries to ascertain this point, but I daresay I shall never get any returns. Secondly, I suspect that a sort of sexual selection has been the most powerful means of changing the races of man. I can show that the different races have a widely different standard of beauty. Among savages the 


\section{The Wallace-Darwin Correspondence}

most powerful men will have the pick of the women, and they will generally leave the most descendants.

I have collected a few notes on Man, but I do not sup. pose I shall ever use them. Do you intend to follow out your views, and if so would you like at some future time to have my few references and notes?

I am sure I hardly know whether they are of any value, and they are at present in a state of chaos.

There is much more that I should like to write but I have not strength.-Believe me, dear Wallace, yours very sincerely,

Ch. Darwin.

Our aristocracy is handsomer? (more hideous according to a Chinese or negro) than the middle classes, from pick of women; but oh what a scheme is primogeniture for destroy. ing Natural Selection! I fear my letter will be barely intelligible to you.

5 Westbourne Grove Terrace, W. May 29 [1864].

My dear Darwin,-YYou are always so ready to appreciate what others do, and especially to overestimate my desultory efforts, that I cannot be surprised at your very kind and flattering remarks on my papers. I am glad, however, that you have made a few critical observations, and am only sorry you were not well enough to make more, as that enables me to say a few words in explanation.

My great fault is haste. An idea strikes me, I think over it for a few days, and then write away with such illustrations as occur to me while going on. I therefore look at the subject almost solely from one point of view. Thus in my paper on $\operatorname{Man}^{2} I$ aim solely at showing that brutes are modified in a great variety of ways by Natural Selection, but that in none of these particular ways can man be modified, because of the superiority of his intellect. I therefore no doubt 1 Anthropolog. Rev., 1864. 


\section{Alfred Russel Wallace}

overlook a few smaller points in which Natural Selection may still act on men and brutes alike. Colour is one of them, and I have alluded to this in correlation to constitution in an abstract I have made at Sclater's request for the Natural History Review.' At the same time, there is so much evidence of migrations and displacements of races of man, and so many cases of peoples of distinct physical characters inhabiting the same or similar regions, and also of races of uniform physical characters inhabiting widely dissimilar regions, that the external characteristics of the chief races of man must $I$ think be older than his present geographical distribution, and the modifications produced by correlation to favourable variations of constitution be only a secondary cause of external modification.

I hope you may get the returns from the Army. They would be very interesting, but $I$ do not expect the results would be farourable to your view.

With regard to the constant battles of savages leading to selection of physical superiority, I think it would be very imperfect, and subject to so many exceptions and irregularities that it could produce no definite result. For instance, the strongest and bravest men would lead, and expose themselves most, and would therefore be most subject to wounds and death. And the physical energy which led to any one tribe delighting in war might lead to its extermination by inducing quarrels with all surrounding tribes and leading them to combine against it. Again, superior cunning, stealth and swiftness of foot, or even better weapons, would often lead to victory as well as mere physical strength. Moreover this kind of more or less perpetual war goes on among all savage peoples. It "could lead therefore to no differential characters, but merely to the keeping up of a certain average standard of bodily and

\section{Nat. Hist. Rev., 1864, p. 328.}




\section{The Wallace-Darwin Correspondence}

mental health and vigour. So with selection of variations adapted to special habits of life, as fishing, paddling, riding, climbing, etc. etc., in different races : no doubt it must act to some extent, but will it be ever so rigid as to induce a definite physical modification, and can we imagine it to have had any part in producing the distinct races that now exist?

The sexual selection you allude to will also, I think, have been equally uncertain in its results. In the very lowest tribes there is rarely much polygamy, and women are more or less a matter of purchase. There is also little difference of social condition, and I think it rarely happens that any healthy and undeformed man remains without wife and children. I very much doubt the often-repeated assertion that our aristocracy are more beautiful than the middle classes. I allow that they present specimens of the highest kind of beauty, but I doubt the average. I have noticed in country places a greater average amount of good looks among the middle classes, and besides, we unavoidably combine in our idea of beauty, intellectual expression and refinement of manner, which often make the less appear the more beautiful. Mere physical beauty-that is, a healthy and regular development of the body and features approaching to the mean or type of European man-I believe is quite as frequent in one class of society as the other, and much more frequent in rural districts than in cities.

With regard to the rank of man in zoological classification, I fear I have not made myself intelligible. I never meant to adopt Owen's or any other such views, but only to point out that from one point of view he was right. I hold that a distinct family for man, as Huxley allows, is all that can possibly be given him zoologically. But at the same time, if my theory is true-that while the animals which surrounded him have been undergoing modification 


\section{Alfred Russel Wallace}

in all parts of their bodies to a generic or even family degree of difference, he has been changing almost wholly in the brain and head-then, in geological antiquity the species of man may be as old as many mammalian families, and the origin of the family man may date back to a period when some of the orders first originated.

As to the theory of Natural Selection itself, I shall always maintain it to be actually yours and yours only. You had worked it out in details I had never thought of, years before I had a ray of light on the subject, and my paper would never have convinced anybody or been noticed as more than an ingenious speculation, whereas your book has revolutionised the study of natural history, and carried away captive the best men of the present age. All the merit I claim is the having been the means of inducing you to write and publish at once.

I may possibly some day go a little more into this subject (of Man), and, if $I$ do, will accept the kind offer of your notes. I am now, however, beginning to write the "Narrative of my Travels" which will occupy me a long time, as I hate writing narrative, and after Bates's brilliant success rather fear to fail. I shall introduce a few chapters on geographical distribution and other such topics.

Sir C. Lyell, while agreeing with my main argument on Man, thinks $I$ am wrong in wanting to put him back into Miocene times, and thinks I do not appreciate the immense interval even to the later Pliocene. But I still maintain my view, which in fact is a logical result of my theory, for if man originated in later Pliocene times, when almost all mammalia were of closely allied species to those now living, and many even identical, then man has not been stationary in bodily structure while animals have been varying, and my theory will be proved to be all wrong. 


\section{The Wallace-Darwin Correspondence}

In Murchison's address to the Geographical Society just delivered he points out Africa as being the oldest existing land. He says there is no evidence of its having been ever submerged during the tertiary epoch. Here, then, is evidently the place to find early man. I hope something good may be found in Borneo, and that then means may be found to explore the still more promising regions of tropical Africa, for we can expect nothing of man very early in Europe.

It has given me great pleasure to find that there are symptoms of improvement in your health. I hope you will not exert yourself too soon or write more than is quite agreeable to you. I think I made out every word of your letter though it was not always easy.-Believe me, my dear Darwin, yours very sincerely,

ALFRED R. WALLACE.

Down, Bromley, Kent, S.E. June 15, 1864.

Dear Wallace,-You must not suppose from my delay that I have not been much interested by your long letter. I write now merely to thank you, and just to say that probably you are right on all the points you touch on except, as I think, about sexual selection, which I will not give up.

My belief in it, however, is contingent on my general beliefs in sexual selection. It is an awful stretcher to believe that a peacock's tail was thus formed; but believing it, I believe in the same principle somewhat modified applied to man.

I doubt whether my notes would be of any use to you, and as far as I remember they are chiefly on sexual selection.

I am very glad to hear that you are on your Travels. I believe you will find it a very convenient vehicle for miscellaneous discussion. With your admirable powers of 


\section{Alfred Russel Wallace}

writing, I cannot doubt that you will make an excellent book.-Believe me, dear Wallace, yours sincerely,

Ch. Darwin.

P.S.-A great gun, Flourens, has written a little dull book against me; which pleases me much, for it is plain that our good work is spreading in France. He speaks of the engouement about this book, "so full of empty and presumptuous thoughts."

Down, Bromley, Kent, S.E. January 29, 1865.

My dear Wallace,-I must ease my mind by saying how much I admire the two papers you have sent me.

That on parrots ${ }^{1}$ contained most new matter to me, and interested me extremely; that in the Geographical Journal ${ }^{2}$ strikes me as an epitome of the whole theory of geographical distribution : the comparison of Borneo and New Guinea, the relation of the volcanic outbursts and the required subsidence, and the comparison of the supposed conversion of the Atlantic into a great archipelago, seemed to me the three best hits. They are both indeed excellent papers.-Believe me yours very sincerely,

Charles Darwin.

Do try what hard work will do to banish painful thoughts. ${ }^{3}$

P.S.-During one of the later French voyages, a wild pig was killed and brought from the Aru Islands to Paris. Am I not right in inferring that this must have been introduced and run wild? If you have a clear opinion on this head, may I quote you ?

\footnotetext{
1 " Read June, 1864."-A. R. W.

" "June 8, 1864."-A. R. W.

" Referring to my broken engagement."-A. R. W.
} 


\section{The Wallace-Darwin Correspondence}

5 Westbourne Grove Terrace, W. January 31, [1865 ?].

Dear Darwin,-Many thanks for your kind letter. I send you now a few more papers. One on Man is not much in your line. The other three are bird lists, but in the introductory remarks are a few facts of distribution that may be of use to you, and as you have them already in the Zoological Proceedings, you can cut these up if you want "extracts."

I hope you do not very much want the Aru pig to be a domestic animal run wild, because $I$ have no doubt myself it was the species peculiar to the New Guinea fauna (Sus papuensis, Less.), a very distinct form. I have no doubt it is this species, though I did not get it myself there, because I was told that on a small island near, called there Pulo babi (Pig Island), was a race of pigs (different from and larger than those of the large islands) which had originated from the wreck of a large ship near a century ago. The productions of the Aru Islands closely resemble those of New Guinea, more than half the species of birds being identical, as well as about half of the few known mammals.

I am beginning to work at some semi-mechanical work, drawing up catalogues of parts of my collection for publication.

I enclose my "carte." Have you a photograph of yourself of any kind you can send me ? When you come to town next, may I beg the honour of a sitting for my brother-in-law, Mr. Sims, 73 Westbourne Grove ?-Yours very sincerely,

Alfred R. Wallact.

P.S.-Your paper on Lythrum salicaria ${ }^{1}$ is most beautiful. What a wonderful plant it is! I long to hear your paper on Tendrils and hear what you have got out of them. My old friend Spruce, a good botanist and close observer,

1 Paper on the three forms of Lythrum.

I 161 


\section{Alfred Russel Wallace}

could probably supply you with some facts on that or other botanical subjects if you would write to him. He is now at Kew, but almost as ill as yourself.-A. R. W.

Down, Bromley, Kent, S.E. February 1, 1865.

My dear Wallace,--I am much obliged for your photograph, for I have lately set up a scientific album; and for the papers, which I will read before long. I enclose my own photo, taken by my son, and I have no other.

I fear it will be a long time before I shall be able to sit to a photographer, otherwise I should be happy to sit to Mr. Sims.

Thanks for information about the Aru pig, which will make me very cautious.

It is a perplexing case, for Nathusius says the skull of the Aru resembles that of the Chinese breed, and he thinks that Sus papuensis has been founded on a young skull; D. Blainville stating that an old skull from New Guinea resembles that of the wild pigs of Malabar, and these belong to the S. scrofa type, which is different from the Chinese domestic breed. The latter has not been found in a wild condition.-Believe me, dear Wallace, yours very sincerely,

Ch. Darwin.

9 St. Mark's Crescent, Regent's Park, N.W. Sept. 18, 1865.

Dear Darwin,-I should have written before to thank you for the copy of your paper on climbing plants, which I read with great interest; I can imagine how much pleasure the working out must have given you. I was afraid you were too ill to make it advisable that you should be bothered with letters.

I write now, in hopes you are better, to communicate a curious case of variation becoming at once hereditary, which was brought forward at the British Association. I send a 


\section{The Wallace-Darwin Correspondence}

note of it on the other side, but if you would like more exact particulars, with names and dates and a drawing of the bird, I am sure Mr. O'Callaghan would send them to you.

I hope to hear that you are better, and that your new book is really to come out next winter.-Believe me yours very faithfully,

Alfred R. Wallace.

Note.-Last spring Mr. O'Callaghan was told by a country boy that he had seen a blackbird with a topknot; on which Mr. O'C. very judiciously told him to watch it and communicate further with him. After a time the boy told him he had found a blackbird's nest, and had seen this crested bird near it and believed he belonged to it. He continued watching the nest till the young were hatched. After a time he told Mr. O'C. that two of the young birds seemed as if they would have topknots. He was told to get one of them as soon as it was fledged. However, he was too late, and they left the nest, but luckily he found them near and knocked one down with a stone, which Mr. O'C. had stuffed and exhibited. It has a fine crest, something like that of a Polish fowl, but larger in proportion to the bird, and very regular and well formed. The male must have been almost like the Umbrella bird in miniature, the crest is so large and expanded.-A. R. W.

Down, Bromley, Kent, S.E. September 22, 1865.

Dear Wallace,-I am much obliged for your extract; I never heard of such a case, though such a variation is perhaps the most likely of any to occur in a state of nature and be inherited, inasmuch as all domesticated birds present races with a tuft or with reversed feathers on their heads. I have sometimes thought that the progenitor of the whole class must have been a crested animal.

Do you make any progress with your Journal of travels? I am the more anxious that you should do so as I have lately read with much interest some papers by you on the ouran- 


\section{Alfred Russel Wallace}

outang, etc., in the Annals, of which $\mathrm{I}$ have lately been reading the latter volumes. I have always thought that Journals of this nature do considerable good by advancing the taste for natural history ; I know in my own case that nothing ever stimulated my zeal so much as reading Humboldt's Personal Narrative. I have not yet received the last part of Linnean I'ransactions, but your paper ${ }^{1}$ at present will be rather beyond my strength, for though somewhat better $I$ can as yet do hardly anything but lie on the sofa and be read aloud to. By the way, have you read Tylor and Lecky ? Both these books have interested me much. I suppose you have read Lubbock $?^{3}$ In the last chapter there is a note about you in which I most cordially concur." I see you were at the British Association, but I have heard nothing of it except what I have picked up in the Reader. I have heard a rumour that the Reader is sold to the Anthropological Society. If you do not begrudge the trouble of another note (for my sole channel of news through Hooker is closed by his illness), I should much like to hear whether the Reader is thus sold. I should be very sorry for it, as the paper would thus become sectional in its tendency. If you write, tell me what you are doing yourself.

The only news which I have about the "Origin" is that Fritz Müller published a few months ago a remarkable book ${ }^{s}$ in its favour, and secondly that a second French edition is just coming out.-Believe me, dear Wallace, yours very sincerely,

CH. Darmin.

2 Probably the one on the Distribution of Malayan Butterflies, Linn. Soc. Trans., xxv.

2 E. B. Tylor's " Early History of Mankind," and Lecky's " Rationalism."

3 "Prehistoric Times."

4 The note speaks of the " characteristic unselfishness" with which Wallace ascribed the theory of Natural Selection to Darwin.

s "Für Darwin." 


\section{The Wallace-Darwin Correspondence}

9 St. Mark's Crescent, Regent's Park. October 2, 1865.

Dear Darwin,-I was just leaving town for a few days when I received your letter, or should have replied at once.

The Reader has no doubt changed hands, and I am inclined to think for the better. It is purchased, I believe, by a gentleman who is a Fellow of the Anthropological Society, but $I$ see no signs of its being made a special organ of that Society. The Editor (and, I believe, proprietor) is a $\mathbf{M r}$. Bendyshe, the most talented man in the Society, and, judging from his speaking, which I have often heard, I should say the articles on "Simeon and Simony," "Metropolitan Sewage," and "France and Mexico," are his, and these are in my opinion superior to anything that has been in the Reader for a long time; they have the point and brilliancy which are wanted to make leading articles readable and popular. The articles on Mill's Political Economy and on Mazzini are also first-rate. He has introduced also the plan of having two, and now three, important articles in each number-one political or social, one literary, and one scientific. Under the old regime they never had an editor above mediocrity, except Masson (? Musson); there was a want of unity among the proprietors as to the aims and objects of the journal; and there was a want of capital to secure the services of good writers. This seems to me to be now all changed for the better, and I only hope the rumour of that bete noire, the Anthropological Society, having anything to do with it may not cause our best men of science to withdraw their support and contributions.

I have read Tylor, and am reading Lecky. I found the former somewhat disconnected and unsatisfactory from the absence of any definite result or any decided opinion on most of the matters treated of.

Lecky I like much, though he is rather tedious and 


\section{Alfred Russel Wallace}

obscure at times. Most of what he says has been said so much $\mathrm{L}$ ore forcibly by Buckle, whose work I have read for the secc 6 time with increased admiration, although with a clear $\checkmark 2 \mathrm{~W}$ of some of his errors. Nevertheless, his is I think una proachably the grandest work of the present century, at ' the one most likely to liberalise opinion. Lubbock's book 's very good, but his concluding chapter very weak. Why re men of science so dreadfully afraid to say what they this : and believe?

In reply to. 'ur kind inquiries about myself, I can only say that $I$ am as amed of my laziness. I have done nothing lately but write , paper on Pigeons for the Ibis, and am drawing up a Cat ogue of my Collection of Birds.

As to my "Tran 's," I cannot bring myself to undertake them yet, and perha $a_{1}$ never shall, unless $I$ should be fortunate enough to get , wife who would incite me thereto and assist me therein - vhich is not likely.

I am glad to hear that the "Origin" is still working its revolutionary way on the Continent. Will Müller's book on it be translated?

I am glad to hear you are a little better. My poor friend Spruce is still worse than you are, and I fear now will not recover. He wants to write a book if he gets well enough.With best wishes, believe me yours very faithfully,

\section{AlFred R. Wallace.}

Down, Bromley, Kent, S.E. January 22, 1866.

My dear Wallace,-I thank you for your paper on Pigeons, ${ }^{1}$ which interested me, as everything that you

1 "On the Pigeons of the Malay Archipelago," Ibis, October, 1865. Wallace points out (p. 366) that " the most striking superabundance of pigeons, as well as of parrots, is confined to the Australo-Malayan sub-regions in which . . . the forest-haunting and fruit-eating mammals, such as monkeys and squirrels, are totally absent." He points out also that monkeys are " exceedingly destructive to eggs and young birds."-Note, " More Letters," i. 265. 


\section{The Wallace-Darwin Correspondence}

write does. Who would ever have dreamed that monkeys influenced the distribution of pigeons and parrots! But I have had a still higher satisfaction; for I finished yesterday your paper in the Linnean Transactions. ${ }^{1}$ It is admirably done. I cannot conceive that the most firm believer in Species could read it without being staggered. Such papers will make many more converts among naturalists than longwinded books such as I shall write if I have strength.

I have been particularly struck with your remarks on dimorphism; but $I$ cannot quite understand one point ( $p$. 22), and should be grateful for an explanation, for I want fully to understand you. ${ }^{2}$ How can one female form be selected and the intermediate forms die out, without also the other extreme form also dying out from not having the advantages of the first selected form ? for, as I understand, both female forms occur on the same island. I quite agree with your distinction between dimorphic forms and varieties; but I doubt whether your criterion of dimorphic forms not

1 “The Geographical Distribution and Variability of the Malayan Papilionidæ," Linn. Soc. Trans., xxv.

2 The passage referred to in this letter as needing further explanation is the following: "The last six cases of mimicry are especially instructive, because they seem to indicate one of the processes by which dimorphic forms have been produced. When, as in these cases, one sex differs much from the other, and varies greatly itself, it may be that individual variations will occasionally occur, having a distant resemblance to groups which are the objects of mimicry, and which it is therefore advantageous to resemble. Such a variety will have a better chance of preservation; the individuals possessing it will be multiplied; and their accidental likeness to the favoured group will be rendered permanent by hereditary transmission, and each successive variation which increases the resemblance being preserved, and all variation departing from the favoured type having less chance of preservation, there will in time result those singular cases of two or more isolated and fixed forms bound together by that intimate relationship which constitutes them the sexes of a single species. The reason why the females are more subject to this kind of modification than the males is probably that their slower flight when laden with eggs, and their exposure to attack while in the act of depositing their eggs upon leaves, render it especially advantageous for them to have additional protection. This they at once obtain by acquiring a resemblance to other species which, from whatever cause, enjoy a comparative immunity from persecution." 


\section{Alfred Russel Wallace}

producing intermediate offspring will suffice; for I know of a good many varieties, which must be so called, that will not blend or intermix, but produce offspring quite like either parent.

I have been particularly struck with your remarks on geological distribution in Celebes. It is impossible that anything could be better put, and [it] would give a cold shudder to the immutable naturalists.

And now I am going to ask a question which you will not like. How does your Journal get on? It will be a shame if you do not popularise your researches.

My health is so far improved that $I$ am able to work one or two hours a day.-Believe me, dear Wallace, yours very sincerely,

Ch. Darwin.

9 St. Mark's Crescent, Regent's Park, N.W. February 4, 1866.

My dear Darwin,-I am very glad to hear you are a little better, and hope we shall soon have the pleasure of seeing your volume on "Variation under Domestication." I do not see the difficulty you seem to feel about two or more female forms of one species. The most common or typical female form must have certain characters or qualities which are sufficiently advantageous to it to enable it to maintain its existence; in general, such as vary much from it die out. But occasionally a variation may occur which has special advantageous characters of its own (such as mimicking a protected species), and then this variation will maintain itself by selection. In no less than three of my polymorphic species of Papilio, one of the female forms mimics the Polydorus group, which, like the Aneas group in America, seems to have some special protection. In two or three other cases one of the female forms is confined to a restricted locality, to the conditions of which it is probably specially adapted. In other cases one of the female forms resembles the male, 168 


\section{The Wallace-Darwin Correspondence}

and perhaps receives a protection from the abundance of the males, in the crowd of which it is passed over. I think these considerations render the production of two or three forms of female very conceivable. The physiological difficulty is to me greater, of how each of two forms of female produces offspring like the other female as well as like itself, but no intermediates ?

If you "know varieties that will not blend or intermix, but produce offspring quite like either parents," is not that the very physiological test of a species which is wanting for the complete proof of the origin of species?

I have by no means given up the idea of writing my Travels, but I think I shall be able to do it better for the delay, as I can introduce chapters giving popular sketches of the subjects treated of in my various papers.

I hope, if things go as I wish this summer, to begin work at it next winter. But I feel myself incorrigibly lazy, and have no such system of collecting and arranging facts or of making the most of my materials as you and many of our hard-working naturalists possess in perfection.-With best wishes, believe me, dear Darwin, yours most sincerely,

ALFRED R. WALLACE.

Down, Bromley, S.E. Tuesday, February, 1866.

My dear Wallace,-After I had dispatched my last note, the simple explanation which you give had occurred to me, and seems satisfactory. I do not think you understand what I mean by the non-blending of certain varieties. It does not refer to fertility. An instance will explain. I crossed the Painted Lady and Purple sweet peas, which are very differently coloured varieties, and got, even out of the same pod, both varieties perfect, but none intermediate. Something of this kind, I should think, must occur at first with your butterflies and the three forms of Lythrum; though these 


\section{Alfred Russel Wallace}

cases are in appearance so wonderful, I do not know that they are really more so than every female in the world producing distinct male and female offspring.

I am heartily glad that you mean to go on preparing your Journal.-Believe me yours very sincerely,

Ch. Darwin.

Hurstpierpoint, Sussex. July 2, 1866.

My dear Darwin,-I have been so repeatedly struck by the utter inability of numbers of intelligent persons to see clearly, or at all, the self-acting and necessary effects of Natural Selection, that I am led to conclude that the term itself, and your mode of illustrating it, however clear and beautiful to many of us, are yet not the best adapted to impress it on the general naturalist public. The two last cases of this misunderstanding are (1) the article on "Darwin and his Teachings" in the last Quarterly Journal of Science, which, though very well written and on the whole appreciative, yet concludes with a charge of something like blindness, in your not seeing that Natural Selection requires the constant watching of an intelligent "chooser," like man's selection to which you so often compare it; and (2) in Janet's recent work on the "Materialism of the Present Day," reviewed in last Saturday's Reader, by an extract from which $I$ see that he considers your weak point to be that you do not see that "thought and direction are essential to the action of Natural Selection." The same objection has been made a score of times by your chief opponents, and I have heard it as often stated myself in conversation. Now, I think this arises almost entirely from your choice of the term Natural Selection, and so constantly comparing it in its effects to man's selection, and also to your so frequently personifying nature as "selecting," as "preferring," as " seeking only the good 


\section{The Wallace-Darwin Correspondence}

of the species," etc., etc. To the few this is as clear as daylight, and beautifully suggestive, but to many it is evidently a stumbling-block. I wish, therefore, to suggest to you the possibility of entirely avoiding this source of misconception in your great work (if not now too late), and also in any future editions of the "Origin," and I think it may be done without difficulty and very effectually by adopting Spencer's term (which he generally uses in preference to Natural Selection), viz. "Survival of the Fittest." This term is the plain expression of the fact; "Natural Selection" is a metaphorical expression of it, and to a certain degree indirect and incorrect, since, even personifying Nature, she does not so much select special variations as exterminate the most unfavourable ones.

Combined with the enormous multiplying powers of all organisms, and the "struggle for existence," leading to the constant destruction of by far the largest proportion -facts which no one of your opponents, as far as I am aware, has denied or misunderstood-" the survival of the fittest," rather than of those which were less fit, could not possibly be denied or misunderstood. Neither would it be possible to say that to ensure the "survival of the fittest" any intelligent chooser was necessary, whereas when you say "Natural Selection" acts so as to choose those that are fittest it is misunderstood, and apparently always will be. Referring to your book, I find such expressions as "Man selects only for his own good; Nature only for that of the being which she tends." This, it seems, will always be misunderstood; but if you had said, "Man selects only for his own good; Nature, by the inevitable survival of the fittest, only for that of the being she tends," it would have been less liable to be so.

I find you use the term Natural Selection in two senses(1) for the simple preservation of favourable and rejection 


\section{Alfred Russel Wallace}

of unfavourable variations, in which case it is equivalent to "survival of the fittest"; (2) for the effect or change produced by this preservation, as when you say, "To sum up the circumstances favourable or unfavourable to natural selection," and, again, "Isolation, also, is an important element in the process of natural selection": here it is not merely "survival of the fittest," but change produced by survival of the fittest, that is meant. On looking over your fourth chapter, I find that these alterations of terms can be in most cases easily made, while in some cases the addition of "or survival of the fittest" after "natural selection" would be best; and in others, less likely to be misunderstood, the original term might stand alone.

I could not venture to propose to any other person so great an alteration of terms, but you, I am sure, will give it an impartial consideration, and, if you really think the change will produce a better understanding of your work, will not hesitate to adopt it. It is evidently also necessary not to personify "nature" too much, though I am very apt to do it myself, since people will not understand that all such phrases are metaphors. Natural Selection is, when understood, so necessary and self-evident a principle that it is a pity it should be in any way obscured; and it therefore occurs to me that the free use of "survival of the fittest," which is a compact and accurate definition of it, would tend much to its being more widely accepted and prevent its being so much misrepresented and misunderstood.

There is another objection made by Janet which is also a very common one. It is that the chances are almost infinite against the particular kind of variation required being coincident with each change of external conditions, to enable an animal to become modified by Natural Selec- 


\section{The Wallace-Darwin Correspondence}

tion in harmony with such changed conditions; especially when we consider that, to have produced the almost in. finite modifications of organic beings, this coincidence must have taken place an almost infinite number of times.

Now it seems to me that you have yourself led to this objection being made by so often stating the case too strongly against yourself. For example, at the commencement of Chapter IV. you ask if it is "improbable that useful variations should sometimes occur in the course of thousands of generations"; and a little further on you say, "unless profitable variations do occur, natural selection can do nothing." Now, such expressions have given your opponents the advantage of assuming that favourable variations are rare accidents, or may even for long periods never occur at all, and thus Janet's argument would appear to many to have great force. I think it would be better to do away with all such qualifying expressions, and constantly maintain (what I certainly believe to be the fact) that variations of every kind are always occurring in every part of every species, and therefore that favourable variations are always ready when wanted. You have, I am sure, abundant materials to prove this, and it is, I believe, the grand fact that renders modification and adaptation to conditions almost always possible. I would put the burthen of proof on my opponents to show that any one organ, structure, or faculty does not vary, even during one generation, among all the individuals of a species; and also to show any mode or way in which any such organ, etc., does not vary. I would ask them to give any reason for supposing that any organ, etc., is ever absolutely identical at any one time in all the individuals of a species, and if not, then it is always varying, and there are always materials which, from the simple fact that the "fittest survive," will 


\section{Alfred Russel Wallace}

tend to the modification of the race into harmony with changed conditions.

I hope these remarks may be intelligible to you, and that you will be so kind as to let me know what you think of them.

I have not heard for some time how you are getting on. I hope you are still improving in health, and that you will be able now to get on with your great work, for which so many thousands are looking with interest.-With best wishes, believe me, my dear Darwin, yours very faithfully,

ALFRED R. WALLACE.

Down, Bromley, Kent, S.E. July 5, [1866].

My dear Wallace,-I have been much interested by your letter, which is as clear as daylight. I fully agree with all that you say on the advantages of $H$. Spencer's excel. lent expression of "the survival of the fittest." This, howerar, had not occurred to me till reading your letter. It is, however, a great objection to this term that it cannot be used as a substantive governing a verb; and that this is a real objection I infer from $H$. Spencer continually using the words "Natural Selection."

I formerly thought, probably in an exaggerated degree, that it was a great advantage to bring into connection natural and artificial selection; this indeed led me to use a term in common, and I still think it some advantage. I wish I had received your letter two months ago, for I would have worked in "the survival," etc., often in the new edition of the "Origin," which is now almost printed off, and of which I will, of course, send you a copy. I will use the term in my next book on Domestic Animals, etc., from which, by the way, I plainly see that you expect much too much. The term Natural Selection has now been so largely used abroad and at home that I doubt whether it 


\section{The Wallace-Darwin Correspondence}

could be given up, and with all its faults I should be sorry to see the attempt made. Whether it will be rejected must now depend on the "survival of the fittest."

As in time the term must grow intelligible, the objections to its use will grow weaker and weaker. I doubt whether the use of any term would have made the subject intelligible to some minds, clear as it is to others; for do we not see, even to the present day, Malthus on Population absurdly misunderstood? This reflection about Malthus has often comforted me when I have been vexed at the misstatement of my views.

As for M. Janet, ${ }^{1}$ he is a metaphysician, and such gentlemen are so acute that I think they often misunderstand common folk. Your criticism on the double sense in which $I$ have used Natural Selection is new to me and unanswerable; but $\mathrm{my}$ blunder has done no harm, for I do not believe that anyone excepting you has ever observed it. Again, I agree that I have said too much about "favourable variations," but I am inclined to think you put the opposite side too strongly; if every part of every being varied, I do not think we should see the same end or object gained by such wonderfully diversified means.

I hope you are enjoying the country and are in good health, and are working hard at your Malay Archipelago book, for I will always put this wish in every note I write to you, like some good people always put in a text. My health keeps much the same, or rather improves, and I am able to work some hours daily.-With many thanks for your interesting letter, believe me, my dear Wallace, yours sincerely,

Ch. Darwin.

P.S.-I suppose you have read the last number of $H$. Spencer; I have been struck with astonishment at the 1 This no doubt refers to Janet's " Matérialisme Contemporain." 


\section{Alfred Russel Wallace}

prodigality of original thought in it. But how unfortunate it is that it seems scarcely ever possible to discriminate between the direct effect of external influences and the "survival of the fittest."

9 St. Mark's Crescent, Regent's Park, N.W. Nov. 19, 1866.

Dear Darwin,-Many thanks for the fourth edition of the "Origin," which I am glad to see grows so vigorously at each moult, although it undergoes no metamorphosis. How curious it is that Dr. Wells should so clearly have seen the principle of Natural Selection fifty years ago, and that it should have struck no one that it was a great principle of universal application in nature!

We are going to have a discussion on "Mimicry, as producing Abnormal Sexual Characters," at the Entomological to-night. I have a butterfly (Diadema) of which the female is metallic blue, the male dusky brown, contrary to the rule in all other species of the genus, and in almost all insects; but the explanation is easy-it mimics a metallic Euploea, and so gets a protection perhaps more efficient than its allies derive from their sombre colours, and which females require much more than males. I read a paper on this at the British Association. Have you the report published at Nottingham in a volume by Dr. Robertson? If so, you can tell me if my paper is printed in full.

I suppose you have read Agassiz's marvellous theory of the Great Amazonian glacier, 2,000 miles long! I presume that will be a little too much, even for you. I have been writing a little popular paper on "Glacial Theories" for the Quarterly Journal of Science of January next, in which I stick up for glaciers in North America and icebergs in the Amazon !

I was very glad to hear from Lubbock that your health is permanently improved. I hope therefore you will be 


\section{The Wallace-Darwin Correspondence}

able to give us a volume per annum of your magnum opus, with all the facts as you now have them, leaving additions to come in new editions.

I am working a little at another family of my butterflies, and find the usual interesting and puzzling cases of variation, but no such phenomena as in the Papilionidæ.With best wishes, believe me, my dear Darwin, yours very faithfully,

Alfred R. Wallace.

6 Queen Anne Street, W. Monday, January, 1867.

My dear Wallace,-I return by this post the Journal." Your résumé of glacier action seems to me very good, and has interested my brother much, and as the subject is new to him he is a better judge. That is quite a new and perplexing point which you specify about the freshwater fishes during the glacial period.

I have also been very glad to see the article on Lyell, which seems to me to be done by some good man.

I forgot to say when with you-but $I$ then indeed did not know so much as I do now-that the sexual, i.e. ornamental, differences in fishes, which differences are some. times very great, offer a difficulty in the wide extension of the view that the female is not brightly coloured on account of the danger which she would incur in the propagation of the species.

I very much enjoyed my long conversation with you; and to-day we return home, and I to my horrid dull work of correcting proof-sheets.--Believe me, my dear Wallace, yours very sincerely,

Charles Darwin.

P.S.-I had arranged to go and see your collection on Saturday evening, but my head suddenly failed after lun. cheon, and I was forced to lie down all the rest of the day.

1 Quarterly Journal of Science, January 7, 1867. "Ice Marks in North Wales," by A. R. Wallace. 


\section{Alfred Russel Wallace}

Down, Bromley, Kent, S.E. February 23, 1867.

Dear Wallace,-I much regretted that I was unable to call on you, but after Monday I was unable even to leave the house. On Monday evening I called on Bates and put a difficulty before him, which he could not answer, and, as on some former similar occasion, his first suggestion was, "You had better ask Wallace." My difficulty is, why are caterpillars sometimes so beautifully and artistically coloured ? Seeing that many are coloured to escape danger, I can hardly attribute their bright colour in other cases to mere physical conditions. Bates says the most gaudy caterpillar he ever saw in Amazonia (of a Sphinx) was con. spicuous at the distance of yards from its black and red colouring whilst feeding on large green leaves. If anyone objected to male butterflies having been made beautiful by sexual selection, and asked why should they not have been made beautiful as well as their caterpillars, what would you answer? I could not answer, but should maintain my ground. Will you think over this, and some time, either by letter or when we meet, tell me what you think? Also, I want to know whether your female mimetic butterfly is more beautiful and brighter than the male?

When next in London I must get you to show me your Kingfishers.

My health is a dreadful evil ; I failed in half my engagements during this last visit to London.-Believe me, yours very sincerely,

C. DarWIn.

The answer to this letter is missing, but in Vol. II. of "My Life," p. 3, Wallace writes :

"On reading this letter I almost at once saw what seemed to be a very easy and probable explanation of the facts. I had then just been preparing for publication (in the Westminster Review) my rather elaborate paper on 178 


\section{The Wallace-Darwin Correspondence}

'Mimicry and Protective Colouring,' and the numerous cases in which specially showy and slow-flying butterflies were . .own to have a peculiar odour and taste which prot.uced them from the attacks of insect-eating birds and other animals led me at once to suppose that the gaudily coloured caterpillars must have a similar protection. I had just ascertained from Mr. Jenner Weir that one of our common white moths (Spilosoma menthastri) would not be eaten by most of the small birds in his aviary, nor by young turkeys. Now, as a white moth is as conspicu. ous in the dusk as a coloured caterpillar in the daylight, this case seemed to me so much on a par with the other that I felt almost sure my explanation would turn out correct. I at once wrote to Mr. Darwin to this effect."

Down, Bromley, Kent, S.E. February 26, 1867.

My dear Wallace,-Bates was quite right, you are the man to apply to in a difficulty. I never heard anything more ingenious than your suggestion, and I hope you may be able to prove it true. That is a splendid fact about the white moths; it warms one's very blood to see a theory thus almost proved to be true. ${ }^{1}$ With respect to the beauty of male butterflies, I must as yet think that it is due to sexual selection; there is some evidence that dragonflies are attracted by bright colours; but what leads me to the above belief is so many male Orthoptera and Cicadas having musical intruments. This being the case, the analogy of birds makes me believe in sexual selection with respect to colour in insects. I wish I had strength and time to make some of the experiments suggested by you; but I thought butterflies would not pair in confinement; I am sure I have heard of some such difficulty. Many years ago I had a dragonfly painted with gorgeous colours, but I never had an opportunity of fairly trying it.

1 I.e., the suggestion that conspicuous caterpillars or perfect insects (e.g. white butterflies) which are distasteful to birds are protected by being easily recognised and avoided. 


\section{Alfred Russel Wallace}

The reason of my being so much interested just at present about sexual selection is that I have almost resolved to publish a little essay on the Origin of Mankind, and I still strongly think (though I failed to convince you, and this to me is the heaviest blow possible) that sexual selection has been the main agent in forming the races of man.

By the way, there is another subject which I shall introduce in my essay, viz. expression of countenance. Now, do you happen to know by any odd chance a very goodnatured and acute observer in the Malay Archipelago who, you think, would make a few easy observations for me on the expression of the Malays when excited by various emotions. For in this case I would send to such person a list of queries.-I thank you for your most interesting letters, and remain yours very sincerely, CH. DARwIN.

\section{St. Mark's Crescent, N.W. March 11, 1867.}

Dear Darwin,-I return your queries, but cannot answer them with any certainty. For the Malays I should say Yes to $1,3,8,9,10$ and 17 , and No to 12,13 and 16 ; but $I$ cannot be certain in any one. But do you think these things are of much importance? I am inclined to think that if you could get good direct observations you would find some of them often differ from tribe to tribe, from island to island, and sometimes from village to village. Some no doubt may be deep-seated, and would imply organic differences; but can you tell beforehand which these are? I presume the Frenchman shrugs his shoulders whether he is of the Norman, Breton, or Gaulish stock. Would it not be a good thing to send your List of Queries to some of the Bombay and Calcutta papers? as there must be numbers of Indian judges and other officers who would be interested and would send you hosts of replies. The 


\section{The Wallace-Darwin Correspondence}

Australian papers and New Zealand might also publish them, and then you would have a fine basis to go on.

Is your essay on Variation in Man to be a supplement to your volume on Domesticated Animals and Cultivated Plants? I would rather see your second volume on "The Struggle for Existence, etc.," for I doubt if we have a sufficiency of fair and accurate facts to do anything with man. Huxley, I believe, is at work upon it.

I have been reading Murray's volume on the Geographical Distribution of Mammals. He has some good ideas here and there, but is quite unable to understand Natural Selection, and makes a most absurd mess of his criticism of your views on oceanic islands.

By the bye, what an interesting volume the whole of your materials on that subject would, I am sure, make.Yours very sincerely,

Alfred R. Wallact.

Down, Bromley, Kent, S.E. March, 1867.

My dear Wallace,-I thank you much for your two notes. The case of Julia Pastrana ${ }^{1}$ is a splendid addition to my other cases of correlated teeth and hair, and I will add it in correcting the proof of my present volume. Pray let me hear in course of the summer if you get any evidence about the gaudy caterpillars. I should much like to give (or quote if published) this idea of yours, if in any way supported, as suggested by you. It will, however, be a long time hence, for I can see that sexual selection is growing into quite a large subject, which I shall introduce into my essay on Man, supposing that I ever publish it.

I had intended giving a chapter on Man, inasmuch as many call him (not quite truly) an eminently domesticated animal; but $I$ found the subject too large for a chapter.

1 A bearded woman having an irregular double set of teeth. See "Animals and Plants," ii. 328. 


\section{Alfred Russel Wallace}

Nor shall I be capable of treating the subject well, and my sole reason for taking it up is that I am pretty well convinced that sexual selection has played an important part in the formation of races, and sexual selection has always been a subject which has interested me much.

I have been very glad to see your impression from memory on the expressions of Malays. I fully agree with you that the subject is in no way an important one : it is simply a "hobby-horse" with me about twenty-seven years old; and after thinking that I would write an essay on Man, it flashed on me that I could work in some "supplemental remarks on expression." After the horrid, tedious, dull work of my present huge and, I fear, unreadable book, I thought I would amuse myself with my hobbyhorse. The subject is, I think, more curious and more amenable to scientific treatment than you seem willing to allow. I want, anyhow, to upset Sir C. Bell's view, given in his most interesting work, "The Anatomy of Expression," that certain muscles have been given to man solely that he may reveal to other men his feelings. I want to try and show how expressions have arisen.

That is a good suggestion about newspapers; but my experience tells me that private applications are generally most fruitful. I will, however, see if I can get the queries inserted in some Indian paper. I do not know names or addresses of any other papers.

I have just ordered, but not yet received, Murray's book : Lindley used to call him a blunder-headed man. It is very doubtful whether I shall ever have strength to publish the latter part of my materials.

My two female amanuenses are busy with friends, and I fear this scrawl will give you much trouble to read.With many thanks, yours very sincerely, $\mathrm{CH}$. DaRwIN. 


\section{The Wallace-Darwin Correspondence}

Down, Bromley, Kent, S.E. April 29, 1867.

Dear Wallace,-I have been greatly interested by your letter $;^{1}$ but your view is not new to me. If you will look at p. 240 of the fourth edition of the "Origin," you will find it very briefly given with two extremes of the peacock and black grouse. A more general statement is given at p. 101 , or at p. 89 of the first edition, for $I$ have long entertained this view, though I have never had space to develop it. But I had not sufficient knowledge to generalise as far as you do about colouring and nesting. In your paper, perhaps you will just allude to my scanty remark in the fourth edition, because in my essay upon Man I intend to discuss the whole subject of sexual selection, explaining, as I believe it does, much with respect to man. I have collected all my old notes and partly written my discussion, and it would be flat work for me to give the leading idea as exclusively from you. But as I am sure from your greater knowledge of ornithology and entomology that you will write a much better discussion than I could, your paper will be of great use to me. Nevertheless, I must discuss the subject fully in my essay on Man. When we met at the Zoological Society and I asked you about the sexual differences in kingfishers, I had this subject in view; as I had when I suggested to Bates the diffculty about gaudy caterpillars which you have so admirably (as I believe it will prove) explained. I have got one capital case (genus forgotten) of an [Australian] bird in which the female has long-tailed plumes and which consequently builds a different nest from all her allies. ${ }^{2}$ With respect

1 The letter to which this is a reply is missing. It evidently refers to Wallace's belief in the paramount importance of protection in the evolution of colour. See also Darwin's letter of February 26, 1867.

2 Menura superba. See "The Descent of Man" (1901), p. 687. Rhynchæa, mentioned on p. 184, is discussed in the "Descent," p. 727. The female is 


\section{Alfred Russel Wallace}

to certain female birds being more brightly coloured than the males, and the latter incubating, I have gone a little into the subject and cannot say that I am fully satisfied. I remember mentioning to you the case of Rhynchæa, but its nesting seems unknown. In some other cases the difference in brightness seemed to me hardly sufficiently accounted for by the principle of protection. At the Falkland Islands there is a carrion hawk in which the female (as $I$ ascertained by dissection) is the brightest coloured, and I doubt whether protection will here apply; but $I$ wrote several months ago to the Falklands to make inquiries. The conclusion to which $I$ have been leaning is that in some of these abnormal cases the colour happened to vary in the female alone, and was transmitted to females alone, and that her variations have been selected through the admiration of the male.

It is a very interesting subject, but $I$ shall not be able to go on with it for the next five or six months, as I am fully employed in correcting dull proof-sheets; when I return to the work I shall find it much better done by you than I could have succeeded in doing.

With many thanks for your very interesting note, believe me, dear Wallace, yours very sincerely,

Ch. Darwin.

It is curious how we hit on the same ideas. I have endeavoured to show in my MS. discussion that nearly the same principles account for young birds not being gaily coloured in many cases-but this is too complex a point for a note.

more brightly coloured than the male and has a convoluted trachea, elsewhere a masculine character. There seems some reason to suppose that " the male undertakes the duty of incubation." 


\section{The Wallace-Darwin Correspondence}

\section{Postscript. $\quad$ Down. April 29.}

My dear Wallace,-On reading over your letter again, and on further reflection, I do not think (as far as I remember my words) that I expressed myself nearly strongly enough as to the value and beauty of your generalisation, viz. that all birds in which the female is conspicuously or brightly coloured build in holes or under domes. I thought that this was the explanation in many, perhaps most cases, but do not think I should erer have extended my view to your generalisation. Forgive me troubling you with this P.S.-Yours,

Ch. Darwin.

Down, Bromley, Kent, S.E. May 5, 1867.

My dear Wallace,-The offer of your valuable notes is most generous, but it would vex me to take so much from you, as it is certain that you could work up the subject very much better than I could. Therefore I earnestly and without any reservation hope that you will proceed with your paper, so that I return your notes.

You seem already to have well investigated the subject. I confess on receiving your note that I felt rather flat at my recent work being almost thrown away, but I did not intend to show this feeling. As a proof how little advance I had made on the subject, I may mention that though I had been collecting facts on the colouring and other sexual differences in mammals, your explanation with respect to the females had not occurred to me. I am surprised at my own stupidity, but I have long recognised how much clearer and deeper your insight into matters is than mine.

I do not know how far you have attended to the laws of inheritance, so what follows may be obvious to you. I have begun my discussion on sexual selection by showing that new characters often appear in one sex and are 


\section{Alfred Russel Wallace}

transmitted to that sex alone, and that from some unknown cause such characters apparently appear oftener in the male than in the female. Secondly, characters may be developed and be confined to the male, and long afterwards be transferred to the female. Thirdly, characters may, again, arise in either sex and be transmitted to both sexes, either in an equal or unequal degree. In this latter case I have supposed that the survival of the fittest has come into play with female birds and kept the female dullcoloured. With respect to the absence of spurs in female gallinaceous birds, I presume that they would be in the way during incubation; at least, I have got the case of a German breed of fowls in which the hens were spurred, and were found to disturb and break their eggs much.

With respect to the females of deer not having horns, I presume it is to save the loss of organised matter.

In your note you speak of sexual selection and protection as sufficient to account for the colouring of all animals; but it seems to me doubtful how far this will come into play with some of the lower animals, such as sea anemones, some corals, etc. etc.

On the other hand, Haeckel has recently well shown that the transparency and absence of colour in the lower oceanic animals, belonging to the most different classes, may be well accounted for on the principle of protection.

Some time or other I should like much to know where your paper on the nests of birds has appeared, and I shall be extremely anxious to read your paper in the Westminster Review.

Your paper on the sexual colouring of birds will, I have no doubt, be very striking.

Forgive me, if you can, for a touch of illiberality about your paper, and believe me yours very sincerely,

Ch. Dartvin. 


\section{The Wallace-Darwin Correspondence}

Down, Bromley, Kent, S.E. July 6, 1867.

My dear Wallace,-I am very much obliged for your article on Mimicry, ${ }^{1}$ the whole of which I have read with the greatest interest. You certainly have the art of putting your ideas with remarkable force and clearness; now that I am slaving over proof-sheets it makes me almost envious.

I have been particularly glad to read about the birds' nests, and I must procure the Intellectual Observer; but the point which I think struck me most was about its being of no use to the Heliconias to acquire in a slight degree a disagreeable taste. What a curious case is that about the coral snakes. The summary, and indeed the whole, is excellent, and I have enjoyed it much.-With many thanks, yours very sincerely,

CH. Darwin.

\section{St. Mark's Crescent, N.W. \\ Wednesday, [August or September, 186r.].}

Dear Darwin,-I am very sorry I was out when you called yesterday. I had just gone to the Zoological Gardens, and I met Sir C. Lyell, who told me you were in town.

If you should have time to go to Bayswater, I think you would be pleased to see the collections which I have displayed there in the form of an exhibition (though the public will not go to see it).

If you can go, with any friends, I should like to meet you there if you can appoint a time.

I am glad to find you continue in tolerable health.Believe me yours very faithfully, ALFRED R. WALLACE.

What do you think of the Duke of Argyll's criticisms, 1 Westminster Review, July, 1867. 


\section{Alfred Russel Wallace}

and the more pretentious one in the last number of the North British Review?

I have written a little article answering them both, but I do not yet know where to get it published.-A. R. W.

$76 \frac{1}{2}$ Westbourne Grove, Bayswater, W. October 1, 1867.

Dear Darwin,-I am sorry I was not in town when your note came. I took a short trip to Scotland after the British Association Meeting, and went up Ben Lawers. It was very cold and wet, and I could not find a companion or I should have gone as far as Glen Roy.

My article on "Creation by Law," in reply to the Duke of Argyll and the North British reviewer, is in the present month's number of the Quarterly Journal of Science. I cannot send you a copy because they do not allow separate copies to be printed.

There is a nice illustration of the predicted Madagascar moth and Angracum sesquipedale.

I shall be glad to know whether I have done it satisfactorily to you, and hope you will not be so very sparing of criticism as you usually are.

I hope you are getting on well with your great book. I hear a rumour that we are to have one vol. of it about Christmas.

I quite forget whether I told you that I have a little boy, now three months old, and have named him Herbert Spencer (having had a brother Herbert). I am now staying chiefly in the country, at Hurstpierpoint, but come up to town once a month at least. You may address simply, "Hurstpierpoint, Sussex."

Hoping your health is tolerable and that all your family are well, believe me, dear Darwin, yours very faithfully,

Alfred R. Wallace. 


\section{The Wallace-Darwin Correspondence}

Down, Bromley, Kent, S.E. October 12 and 13, 1867.

My dear Wallace,-I ordered the journal a long time ago, but by some oversight received it only yesterday and read it. You will think my praise not worth having from being so indiscriminate, but if I am to speak the truth, I must say I admire every word.

You have just touched on the points which I particularly wished to see noticed. I am glad you had the courage to take up Angroecum ${ }^{1}$ after the Duke's attack; for I believe the principle in this case may be widely applied. I like the figure, but $I$ wish the artist had drawn a better sphinx.

With respect to beauty, your remarks on hideous objects and on flowers not being made beautiful except when of practical use to them strike me as very good.

On this one point of beauty, I can hardly think that the Duke was quite candid. I have used in the concluding paragraph of my present book precisely the same argument as you have, even bringing in the bulldog, ${ }^{2}$ with respect to variations not having been specially ordained. Your

1 Angræcum sesquipedale, a Madagascar orchid, with a whip-like nectary, 11 to 12 in. in length, which, according to Darwin ("Fertilisation of Orchids," 2nd Edit., p. 163), is adapted to the visits of a moth with a proboscis of corresponding length. He points out that there is no difficulty in believing in the existence of such a moth as F. Müller had described (Nature, 1873, p. 223), a Brazilian sphinx-moth with a trunk 10 to 11 in. in length. Moreover, Forbes had given evidence to show that such an insect does exist in Madagascar (Nature, 1873, p. 121). The case of Angræcum was put forward by the Duke of Argyll as being necessarily due to the personal contrivance of the Deity. Mr. Wallace shows (p. 476, Quarterly Journal of Science, 1867) that both proboscis and nectary might be increased in length by means of Natural Selection. It may be added that Hermann Müller has shown good grounds for believing that mutual specialisation of this kind is beneficial both to insect and to plant.

2 "Variation of Animals and Plants," 1st Edit., ii. 431. " Did He cause the frame and mental qualities of the dog to vary in order that a breed might be formed of indomitable ferocity, with jaws fitted to pin down the bull for man's brutal sport?" 


\section{Alfred Russel Wallace}

metaphor of the river ${ }^{1}$ is new to me, and admirable; but your other metaphor, in which you compare classification and complex machines, does not seem to me quite appropriate, though I cannot point out what seems deficient. The point which seems to me strong is that all naturalists admit that there is a natural classification, and it is this which descent explains. I wish you had insisted a little more against the North British ${ }^{2}$ reviewer assuming that each variation which appears is a strongly marked one; though by implication you have made this very plain. Nothing in your whole article has struck me more than your view with respect to the limit of fleetness in the racehorse and other such cases; I shall try and quote you on this head in the proof of my concluding chapter. I quite missed this explanation, though in the case of wheat I hit upon something analogous. I am glad you praise the Duke's book, for I was much struck with it. The part about flight seemed to me at first very good, but as the wing is articulated by a ball-and-socket joint, $I$ suspect the Duke would find it very difficult to give any reason against the belief that the wing strikes the air more or less obliquely. I have been very glad to see your article and the drawing of the butterfly in Science Gossip. By the way, I cannot but think that you push protection too

1 See Wallace, Quarterly Journ. of Sci., 1867, pp. 477-8. He imagined an observer examining a great river system, and finding everywhere adaptations which reveal the design of the Creator. "He would see special adaptations to the wants of man in the broad, quiet, navigable rivers, through fertile alluvial plains, that would support a large population, while the rocky streams and mountain torrents were confined to those sterile regions suitable for a small population of shepherds and herdsmen."

2 At p. 485 Wallace deals with Fleeming Jenkin's review in the North British Review, 1867. The review strives to show that there are strict limitations to variation, since the most rigorous and long-continued selection does not indefinitely increase such a quality as the fleetness of a racehorse. On this.Wallace remarks that the argument "fails to meet the real question," which is not whether indefinite change is possible, but " whether such differences as do occur in nature could have been produced by the accumulation of variations by selection." 


\section{The Wallace-Darwin Correspondence}

far in some cases, as with the stripes on the tiger. I have also this morning read an excellent abstract in the Gardeners' Chronicle of your paper on nests; ${ }^{\prime}$ I was not by any means fully converted by your letter, but I think now I am so; and I hope it will be published somewhere in extenso. It strikes me as a capital generalisation, and appears to me even more original than it did at first.

I have had an excellent and cautious letter from $\mathrm{Mr}$. Geach of Singapore with some valuable answers on expression, which I owe to you.

I heartily congratulate you on the birth of "Herbert Spencer," and may he deserve his name, but I hope he will copy his father's style and not his namesake's. Pray observe, though I fear I am a month too late, when tears are first secreted enough to overflow; and write down date.

I have finished Vol. I. of my book, and I hope the whole will be out by the end of November; if you have the patience to read it through, which is very doubtful, you will find, I think, a large accumulation of facts which will be of service to you in your future papers, and they could not be put to better use, for you certainly are a master in the noble art of reasoning.

Have you changed your house to Westbourne Grove?

Believe me, my dear Wallace, yours very sincerely,

Ch. Darwin.

This letter is so badly expressed that it is barely intelligible, but I am tired with proofs.

P.S.-Mr. Warington has lately read an excellent and spirited abstract of the "Origin" before the Victoria Institute, and as this is a most orthodox body he has gained

1 Abstract of a paper on " Birds' Nests and Plumage," read before the British Association. See Gard. Chron., 1867, p. 1047. 


\section{Alfred Russel Wallace}

the name of the devil's adrocate. The discussion which followed during three consecutive meetings is very rich from the nonsense talked. If you would care to see the number I could lend it you.

I forgot to remark how capitally you turn the table on the Duke, when you make him create the Angrcecum and moth by special creation.

Hurstpierpoint. October 22, 1867.

Dear Darwin,-I am very glad you approve of my article on "Creation by Law" as a whole.

The "machine metaphor" is not mine, but the North British reviewer's. I merely accept it and show that it is on our side and not against us, but $I$ do not think it at all a good metaphor to be used as an argument either way. I did not half develop the argument on the limits of variation, being myself limited in space; but I feel satisfied that it is the true answer to the very common and very strong objection, that "variation has strict limits." The fallacy is the requiring variation in domesticity to go beyond the limits of the same variation under nature. It does do so sometimes, however, because the conditions of existence are so different. I do not think a case can be pointed out in which the limits of variation under domestication are not up to or beyond those already marked out in nature, only we generally get in the species an amount of change which in nature occurs only in the whole range of the genus or family.

The many cases, however, in which variation has gone far beyond nature and has not yet stopped are ignored. For instance, no wild pomaceous fruit is, I believe, so large as our apples, and no doubt they could be got much larger if flavour, etc., were entirely neglected.

I may perhaps push "protection" too far sometimes, for 192 


\section{The Wallace-Darwin Correspondence}

it is my hobby just now, but as the lion and the tiger are, I think, the only two non-arboreal cats, I think the tiger stripe agreeing so well with its usual habitat is at least a probable case.

I am rewriting my article on Birds' Nests for the new Natural History Review.

I cannot tell you about the first appearance of tears, but it is very early-the first week or two, I think. I can see the Victoria Institute Magazine at the London Library.

I shall read your book, every word. I hear from Sir C. Lyell that you come out with a grand new theory at the end, which even the cautious (!) Huxley is afraid of! Sir C. said he could think of nothing else since he read it. I long to see it.

My address is Hurstpierpoint during the winter, and, when in town, $76 \frac{1}{2}$ Westbourne Grove.

I suppose you will now be going on with your book on Sexual Selection and Man, by way of relaxation! It is a glorious subject, but will require delicate handling.-Yours very faithfully,

ALFRED R. WALLACE.

10 Duchess Street, $W$. February 7, 1868.

Dear Darwin,-I have to thank you for signing the Memorial as to the East London Museum, and also for your kindness in sending me a copy of your great book, which I have only just received. I shall take it down in the country with me next week, and enjoy every line at my leisure.

Allow me also to congratulate you on the splendid position obtained by your second son at Cambridge.

You will perhaps be glad to hear that I have been for some time hammering away at my Travels, but I fear I shall make a mess of it. I shall leave most of the Natural $\mathrm{N}$ 


\section{Alfred Russel Wallace}

History generalisation, etc., for another work, as if I wait to incor, orate all, I may wait for years.-Hoping you are quite wel. believe me yours very faithfully,

ALFRED R. Wallack.

.7own, Bromley, Kent, S.E. February 22, [1868 ?].

My dear Wal' zce,-I am hard at work on sexual selection and am drive. half mad by the number of collateral points which require investigation, such as the relative numbers of the two sexes, and especially on polygamy. Can you aid me with respect to birds which have strongly marked secondary sexual characters, such as birds of paradise, humming-birds, the rupicola or rock-thrush, or any other such cases? Many gallinaceous birds certainly are polygamous. I suppose that birds may be known not to be polygamous if they are seen during the whole breeding season to associate in pairs, or if the male incubates, or aids in feeding the young. Will you have the kindness to turn this in your mind? but it is a shame to trouble you now that, as I am heartily glad to hear, you are at work on your Malayan Travels. I am fearfully puzzled how far to extend your protective views with respect to the females in various classes. The more $I$ work, the more important sexual selection apparently comes out.

Can butterflies be polygamous ?-i.e. will one male impregnate more than one female?

Forgive me troubling you, and I daresay I shall have to ask your forgiveness again, and believe me, my dear Wallace, yours most sincerely,

Ch. Darwin.

P.S.-Baker has had the kindness to set the Entomological Society discussing the relative numbers of the sexes in insects, and has. brought out some very curious results. 


\section{The Wallace-Darwin Correspondence}

Is the orang polygamous? But I daresay I shall find that in your papers in (I think) the Annals and Magazine of Natural History.

The following group of letters deals with the causes of the sterility of hybrids (see note in "More Letters," p. 287). Darwin's final view is given in the "Origin," 6th edit., 1900, p. 384 . He acknowledges that it would be advantageous to two incipient species if, by physiological isolation due to mutual sterility, they could be kept from blending; but he continues: "After mature reflection, it seems to me that this could not have been effected through Natural Selection." And finally he concludes (p. 386) : "But it would be superfluous to discuss this question in detail ; for with plants we have conclusive evidence that the sterility of crossed species must be due to some principle quite independent of Natural Selection. Both Gärtner and Kolreuter have proved that in genera including numerous species a series can be formed from species which, when crossed, yield fewer and fewer seeds, to species which never produce a single seed, but yet are affected by the pollen of certain other species, for the germen swells. It is here manifestly impossible to select the more sterile individuals, which have already ceased to yield seeds; so that this acme of sterility, when the germen alone is affected, cannot have been gained through selection; and from the laws governing the various grades of sterility being so uniform throughout the animal and vegetable kingdoms, we may infer that the cause, whatever it may be, is the same or nearly the same in all cases."

Wallace still adhered to his view (see "Darwinism," 1889, p. 174, also p. 292 of " More Letters," note 1, and Letter 211, p. 299). The discussion of 1868 began with a letter from Wallace, written towards the end of February, giving his opinion on the "Variation of Animals and Plants"; the discussion on the sterility of hybrids is at p. 185, Vol. II., 1st edit. 


\section{Alfred Russel Wallace}

(Second and third sheets of a letter from Wallace, apparently of February, 1868.)

I am in the second volume of your book, and I have been astonished at the immense number of interesting facts you have brought together. I read the chapter on Pangenesis first, for I could not wait. I can hardly tell you how much $I$ admire it. It is a positive comfort to me to have any feasible explanation of a difficulty that has always been haunting me, and I shall never be able to give it up till a better one supplies its place, and that I think hardly possible. You have now fairly beaten Spencer on his own ground, for he really offered no solution of the difficulties of the problem. The incomprehensible minuteness and vast numbers of the physiological germs or atoms (which themselves must be compounded of numbers of Spencer's physiological units) is the only difficulty, but that is only on a par with the difficulties in all conceptions of matter, space, motion, force, etc. As I understood Spencer, his physiological units were identical throughout each species, but slightly different in each different species; but no attempt was made to show how the identical form of the parent or ancestors came to be built up of such units.

The only parts I have yet met with where I somewhat differ from your views are in the chapter on the Causes of Variability, in which I think several of your arguments are unsound: but this is too long a subject to go into now.

Also, I do not see your objection to sterility between allied species having been aided by Natural Selection. It appears to me that, given a differentiation of a species into two forms, each of which.was adapted to a special sphere of existence, every slight degree of sterility would be a positive advantage, not to the individuals who were sterile, 


\section{The Wallace-Darwin Correspondence}

but to each form. If you work it out, and suppose the two incipient species A, B to be divided into two groups, one of which contains those which are fertile when the two are crossed, the other being slightly sterile, you will find that the latter will certainly supplant the former in the struggle for existence, remembering that you have shown that in such a cross the offspring would be more vigorous than the pure breed, and would therefore certainly soon supplant them, and as these would not be so well adapted to any special sphere of existence as the pure species $A$ and $B$, they would certainly in their turn give way to $A$ and $B$.

I am sure all naturalists will be disgusted at the malicious and ignorant article in the Athenceum. It is a disgrace to the paper, and I hope someone will publicly express the general opinion of it. We can expect no good reviews of your book till the quarterlies or best monthlies come out. ... I shall be anxious to see how Pangenesis is received.Believe me yours very faithfully, ALFRED R. WaLLACE.

Down, Bromley, Kent, S.E. February 27, 1868.

My dear Wallace,-You cannot well imagine how much I have been pleased by what you say about Pangenesis. None of my friends will speak out, except, to a certain extent, Sir H. Holland, ${ }^{1}$ who found it very tough reading, but admits that some view "closely akin to it" will have to be admitted. Hooker, as far as I understand him, which I hardly do at present, seems to think that the hypothesis is little more than saying that organisms have such and such potentialities. What you say exactly and fully expresses my feeling, viz. that it is a relief to have some feasible explanation of the various facts, which can be given up as soon as any better hypothesis is found. It has

1 Sir Henry Holland, Bart., M.D., F.R.S., a writer on Mental Physiology and other scientific subjects (b. 1788, d. 1873). 


\section{Alfred Russel Wallace}

certainly been an immense relief to my mind; for I have been stumbling over the subject for years, dimly seeing that some relation existed between the various classes of facts. I now hear from $\mathrm{H}$. Spencer that his views quoted in my footnote refer to something quite distinct, as you seem to have perceived.

I shall be very glad to hear, at some future day, your criticisms on the causes of variability.

Indeed, I feel sure that $I$ am right about sterility and Natural Selection. Two of my grown-up children who are acute reasoners have two or three times at intervals tried to prove me wrong, and when your letter came they had another try, but ended by coming back to my side. I do not quite understand your case, and we think that a word or two is misplaced. I wish some time you would consider the case under the following point of view. If sterility is caused or accumulated through Natural Selection, then, as every degree exists up to absolute barrenness, Natural Selection must have the power of increasing it. Now take two species, $A$ and $B$, and assume that they are (by any means) half-sterile, i.e. produce half the full number of offspring. Now try and make (by Natural Selection) A and B absolutely sterile when crossed, and you will find how difficult it is. I grant, indeed it is certain, that the degree of sterility of the individuals of $A$ and $B$ will vary, but any such extra-sterile individuals of, we will say, A, if they should hereafter breed with other individuals of $A$, will bequeath no advantage to their progeny, by which these families will tend to increase in number over other families of $A$, which are not more sterile when crossed with B. But I do not know that I have made this any clearer than in the chapter in my, book. It is a most difficult bit of reasoning, which $I$ have gone over and over again on paper with diagrams. 


\section{The Wallace-Darwin Correspondence}

I shall be intensely curious to see your article in the Journal of Travel.

Many thanks for such answers as you could give. From what you say I should have inferred that birds of paradise were probably polygamous. But after all, perhaps it is not so important as I thought. I have been going through the whole animal kingdom in reference to sexual selection, and $I$ have just got to the beginning of Lepidoptera, i.e. to end of insects, and shall then pass on to Vertebrata. But my ladies next week are going (ill-luck to it) to take me nolens-volens to London for a whole month.

I suspect Owen wrote the article in the Athencum, but I have been told that it is Berthold Seeman. The writer despises and hates me.

Hearty thanks for your letter-you have indeed pleased me, for I had given up the great god Pan as a stillborn deity. I wish you could be induced to make it clear with your admirable powers of elucidation in one of the scientific journals.

I think we almost entirely agree about sexual selection, as I now follow you to large extent about protection to females, having always believed that colour was often transmitted to both sexes; but I do not go quite so far about protection.-Always yours most sincerely, CH. DARwiN.

\section{Hurstpierpoint. March 1, 1868.}

My dear Darwin,-I beg to enclose what appears to me a demonstration, on your own principles, that Natural Selection could produce sterility of hybrids.

If it does not convince you I shall be glad if you will point out where the fallacy lies. I have taken the two cases of a slight sterility overcoming a perfect fertility, and of a perfect sterility overcoming a partial fertility-the beginning and end of the process. You admit that variations 


\section{Alfred Russel Wallace}

in fertility and sterility occur, and I think you will also admit that if $I$ demonstrate that a considerable amount of sterility would be advantageous to a variety, that is suffcient proof that the slightest variation in that direction would be useful also, and would go on accumulating.

Sir C. Lyell spoke to me as if he greatly admired pangenesis. I am very glad $\mathrm{H}$. Spencer at once acknowledges that his view was something quite distinct from yours. Although, as you know, I am a great admirer of his, I feel how completely his view failed to go to the root of the matter, as yours does. His explained nothing, though he was evidently struggling hard to find an explanation. Yours, as far as I can see, explains everything in growth and reproduction, though of course the mystery of life and consciousness remains as great as ever.

Parts of the chapter on Pangenesis I found hard reading, and have not quite mastered yet, and there are also throughout the discussions in Vol. II. many bits of hard reading on minute points which we, who have not worked experimentally at cultivation and crossing as you have done, can hardly see the importance of, or their bearing on the general question.

If $I$ am asked, I may perhaps write an article on the book for some periodical, and if so shall do what I can to make pangenesis appreciated.

I suppose Mrs. Darwin thinks you must have a holiday, after the enormous labour of bringing out such a book as that. I am sorry I am not now staying in town. I shall, however, be up for two days on Thursday, and shall hope to see you at the Linnean, where Mr. Trimen has a paper on some of his wonderful South African mimetic butterflies.

I hope this will reach you before you leave.-Believe me yours very faithfully,

ALFRED R. WALLACE. 


\section{The Wallace-Darwin Correspondence}

Hurstpierpoint. March 8, 1868.

Dear Darwin,-I am very sorry your letter came back here while I was going to town, or I should have been very pleased to have seen you.

Trimen's paper at the Linnean was a very good one, but the only opponents were Andrew Murray and $B$. Seeman. The former talked utter nonsense about the " harmony of nature" produced by "polarisation," alike in "rocks, plants and animals," etc. etc. etc. And Seeman objected that there was mimicry among plants, and that our theory would not explain it.

Lubbock answered them both in his best manner.

Pray take your rest, and put my last notes by till you return to Down, or let your son discover the fallacies in them.

Would you like to see the specimens of pupæ of butterflies whose colours have changed in accordance with the colour of the surrounding objects? They are very curious, and Mr. T. W. Wood, who bred them, would, I am sure, be delighted to bring them to show you. His address is 89 Stanhope Street, Hampstead Road, N.W.-Believe me yours very faithfully,

Alfred R. WALlace.

Darwin had already written a short note to Wallace expressing a general dissent from his views.

4 Chester Place, Regent's Park, N.W. March 17, 1868.

My dear Wallace,-Many thanks about Pieridæ. I have no photographs up here, but will remember to send one from Down. Should you care to have a large one, of treble or quadruple common size, I will with pleasure send you one under glass cover, to any address you like in London, either now or hereafter. I grieve to say we shall not be here on April 2nd, as we return home on the 31st. In 201 


\section{Alfred Russel Wallace}

summer I hope that Mrs. Wallace and yourself will pay us a visit at Down, soon after you return to London; for I am sure you will allow me the freedom of an invalid.

My paper to-morrow at the Linnean Society is simply to prove, alas! that primrose and cowslip are as good species as any in the world, and that there is no trustworthy evidence of one producing the other. The only interesting point is the frequency of the production of natural hybrids, i.e. oxlips, and the existence of one kind of oxlip which constitutes a third good and distinct species. I do not suppose that I shall be able to attend the Linnean Society to-morrow.

I have been working hard in collecting facts on sexual selection every morning in London, and have done a good deal; but the subject grows more and more complex, and in many respects more difficult and doubtful. I have had grand success this morning in tracing gradational steps by which the peacock tail has been developed : I quite feel as if I had seen a long line of its progenitors.

I do not feel that I shall grapple with the sterility argument till my return home; $I$ have tried once or twice and it has made my stomach feel as if it had been placed in a vice. Your paper has driven three of my children halfmad-one sat up to twelve o'clock over it. My second son, the mathematician, thinks that you have omitted one almost inevitable deduction which apparently would modify the result. He has written out what he thinks, but I have not tried fully to understand him. I suppose that you do not care enough about the subject to like to see what he has written?

I hope your book progresses.

I am intensely anxious to see your paper in Murray's Journal.-My dear Wallace, yours very sincerely,

Ch. Dartin. 


\section{The Wallace-Darwin Correspondence}

Hurstpierpoint. March 19, 1868.

Dear Darwin,-I should very much value a large photograph of you, and also a carte for my album, though it is too bad to ask you for both, as you must have so many applicants.

I am sorry I shall not see you in town, but shall look forward with pleasure to paying you a visit in the summer.

I am sorry about the Primulas, but I feel sure some such equally good case will some day be discovered, for it seems impossible to understand how all natural species whatever should have acquired sterility. Closely allied forms from adjacent islands would, I should think, offer the best chance of finding good species fertile inter se; since even if Natural Selection induces sterility I do not see how it could affect them, or why they should always be sterile, and varieties never.

I am glad you have got good materials on sexual selection. It is no doubt a difficult subject. One difficulty to me is, that I do not see how the constant minute variations, which are sufficient for Natural Selection to work with, could be sexually selected. We seem to require a series of bold and abrupt variations. How can we imagine that an inch in the tail of a peacock, or a quarter of an inch in that of the bird of paradise, would be noticed and preferred by the female?

Pray let me see what your son says about the sterility selection question. I am deeply interested in all that con. cerns the powers of Natural Selection, but, though I admit there are a few things it cannot do, I do not yet believe sterility to be one of them.

In case your son has turned his attention to mathematical physics, will you ask him to look at the enclosed question, 


\section{Alfred Russel Wallace}

which I have vainly attempted to get an answer to ?-Believe me yours very faithfully,

AlfRed R. Wallace.

4 Chester Place, Regent's Park, N.W. March 19-24, 1868.

My dear Wallace,-I have sent your query to Cambridge to my son. He ought to answer it, for he got his place of Second Wrangler chiefly by solving very difficult problems. I enclose his remarks on two of your paragraphs: I should like them returned some time, for I have not studied them, and let me have your impression.

$I$ have told E. Edwards to send one of my large photographs to you addressed to $76 \frac{1}{2}$ Westbourne Grove, not to be forwarded. When at home $I$ will send my carte.

The sterility is a most [? puzzling] problem. I can see so far, but I am hardly willing to admit all your assumptions, and even if they were all admitted, the process is so complex and the sterility (as you remark in your note) so universal, even with species inhabiting quite distinct countries (as I remarked in my chapter), together with the frequency of a difference in reciprocal unions, that I cannot persuade myself that it has been gained by Natural Selection, any more than the difficulty of grafting distinct genera and the impossibility of grafting distinct families. You will allow, I suppose, that the capacity of grafting has not been directly acquired through Natural Selection.

I think that you will be pleased with the second volume or part of Lyell's Principles, just out.

In regard to sexual selection. A girl sees a handsome man, and without observing whether his nose or whiskers are the tenth of an inch longer or shorter than in some other man, admires his appearance and says she will marry him. So, I suppose, with the pea-hen; and the tail has been increased in length merely by, on the whole, presenting a more gorgeous appearance. Jenner Weir, however, 


\section{The Wallace-Darwin Correspondence}

has given me some facts showing that birds apparently. admire details of plumage.-Yours most sincerely,

C. Darwin.

Hurstpierpoint. March 24, [1868 ?].

Dear Darwin,-Many thanks for the photo, which I shall get when I go to town.

I return your son's notes with my notes on them.

Without going into any details, is not this a strong general argument?-

1. A species varies occasionally in two directions, but owing to their free intercrossing they (the variations) never increase.

2. A change of conditions occurs which threatens the existence of the species, but the two varieties are adapted to the changing conditions, and, if accumulated, will form two new species adapted to the new conditions.

3. Free crossing, however, renders this impossible, and so the species is in danger of extinction.

4. If sterility could be induced, then the pure races would increase more rapidly and replace the old species.

5. It is admitted that partial sterility between varieties does occasionally occur. It is admitted the degree of this sterility varies. Is it not probable that Natural Selection can accumulate these variations and thus save the species ?

If Natural Selection can not do this, how do species ever arise, except when a variety is isolated?

Closely allied species in distinct countries being sterile is no difficulty, for either they diverged from a common ancestor in contact, and Natural Selection increased the sterility, or they were isolated, and have varied since, in which case they have been for age influenced by distinct conditions which may well produce sterility.

If the difficulty of grafting was as great as the difficulty 205 


\section{Alfred Russel Wallace}

of crossing, and as regular, I admit it would be a most serious objection. But it is not. I believe many distinct species can be grafted while others less distinct cannot. The regularity with which natural species are sterile together, even when very much alike, I think is an argument in favour of the sterility having been generally produced by Natural Selection for the good of the species.

The other difficulty, of unequal sterility of reciprocal crosses, seems none to me; for it is a step to more complete sterility, and as such would be useful and would be increased by selection.

I have read Sir C. Lyell's second volume with great pleasure. He is, as usual, very cautious, and hardly ever expresses a positive opinion, but the general effect of the whole book is very strong, as the argument is all on our side.

I am in hopes it will bring in a new set of converts to Natural Selection, and will at all events lead to a fresh ventilation of the subject.-Believe me yours very faithfully,

AlfRed R. Wallace.

4 Chester Place, Regent's Park, N.W. March 27, 1868.

My dear Wallace,-My son has failed in your problem, and says that it is "excessively difficult": he says you will find something about it in Thomson and Tait, "Natural Philosophy" (art. 649). He has, however, sent the solution, if the plate rested on a square rim, but he supposes this will not answer your purpose; nevertheless, I have forwarded it by this same post. It seems that the rim being round makes the problem much more difficult.

I enclose my photograph, which I have received from Down. I sent your answer to George on his objection to your argument on sterility, but have not yet heard from him. I dread beginning to think over this fearful prob- 


\section{The Wallace-Darwin Correspondence}

lem, which I believe beats the plate on the circular rim; but I will sometime. I foresee, however, that there are so many doubtful points that we shall never agree. As far as a glance serves it seems to me, perhaps falsely, that you sometimes argue that hybrids have an advantage from greater vigour, and sometimes a disadvantage from not being so well fitted to their conditions. Heaven protect my stomach whenever I attempt following your argument! - Yours most sincerely,

C. Darwin.

Down, Bromley, Kent. April 6, 1868.

My dear Wallace,-I have been considering the terrible problem. Let me first say that no man could have more earnestly wished for the success of Natural Selection in - regard to sterility than I did, and when I considered a general statement (as in your last note) $I$ always felt sure it could be worked out, but always failed in detail, the cause being, as I believe, that Natural Selection cannot effect what is not good for the individual, including in this term a social community. It would take a volume to discuss all the points; and nothing is so humiliating to me as to agree with a man like you (or Hooker) on the premises and disagree about the result.

I agree with my son's argument and not with rejoinder. The cause of our difference, I think, is that I look at the number of offspring as an important element (all circumstances remaining the same) in keeping up the average number of individuals within any area. I do not believe that the amount of food by any means is the sole determining cause of number. Lessened fertility is equivalent to a new source of destruction. I believe if in one district a species produce from any cause fewer young, the deficiency would be supplied from surrounding districts. This applies to your par. 5. If the species produced fewer young 207 


\section{Alfred Russel Wallace}

from any cause in every district, it would become extinct unless its fertility were augmented through Natural Selection (see H. Spencer).

I demur to the probability and almost to the possibility of par. 1, as you start with two forms, within the same area, which are not mutually sterile, and which yet have supplanted the parent-form (par. 6). I know of no ghost of a fact supporting belief that disinclination to cross accompanies sterility. It cannot hold with plants, or the lower fixed aquatic animals. I saw clearly what an immense aid this would be, but gave it up. Disinclination to cross seems to have been independently acquired, probably by Natural Selection; and I do not see why it would not have sufficed to have prevented incipient species from blending to have simply increased sexual disinclination to cross.

Par. 11: I demur to a certain extent to amount of sterility and structural dissimilarity necessarily going together, except indirectly and by no means strictly. Look at the case of pigeons, fowls, and cabbages.

$I$ overlooked the advantage of the half-sterility of reciprocal crosses; yet, perhaps from novelty, I do not feel inclined to admit the probability of Natural Selection having done its work so clearly.

I will not discuss the second case of utter sterility; but your assumptions in par. 13 seem to me much too complicated. I cannot believe so universal an attribute as utter sterility between remote species was acquired in so complex a manner. I do not agree with your rejoinder on grafting; I fully admit that it is not so closely restricted as crossing; but this does not seem to me to weaken the case as one of analogy. The incapacity of grafting is likewise an invariable attribute of plants sufficiently remote from each other, and sometimes of plants pretty closely allied.

The difficulty of increasing the sterility, through Natural 208 


\section{The Wallace-Darwin Correspondence}

Selection, of two already sterile species seems to me best brought home by considering an actual case. The cowslip and primrose are moderately sterile, yet occasionally produce hybrids: now these hybrids, two or three or a dozen in a whole parish, occupy ground which might have been occupied by either pure species, and no doubt the latter suffer to this small extent. But can you conceive that any individual plants of the primrose and cowslip, which happened to be mutually rather more sterile (i.e. which when crossed yielded a few less seeds) than usual, would profit to such a degree as to increase in number to the ultimate exclusion of the present primrose and cowslip ? I cannot.

My son, I am sorry to say, cannot see the full force of your rejoinder in regard to the second head of continually augmented sterility. You speak in this rejoinder, and in par. 5, of all the individuals becoming in some slight degree sterile in certain districts; if you were to admit that by continued exposure to these same conditions the sterility would inevitably increase, there would be no need of Natural Selection. But I suspect that the sterility is not caused so much by any particular conditions, as by long habituation to conditions of any kind. To speak according to pangenesis, the gemmules of hybrids are not injured, for hybrids propagate freely by buds; but their reproductive organs are somehow affected, so that they cannot accumulate the proper gemmules, in nearly the same manner as the reproductive organs of a pure species become affected when exposed to unnatural conditions.

This is a very ill-expressed and ill-written letter. Do not answer it, unless the spirit urges you. Life is too short for so long a discussion. We shall, I greatly fear, never agree.-My dear Wallace, most sincerely yours,

Ch. Dartin. 


\section{Alfred Russel Wallace}

Hurstpierpoint. [?] April 8, 1868.

Dear Darwin,-I am sorry you should have given yourself the trouble to answer my ideas on Sterility. If you are not convinced, I have little doubt but that I am wrong; and in fact I was only half convinced by my own arguments, and I now think there is about an even chance that Natural Selection may or not be able to accumulate sterility. If my first proposition is modified to the existence of a species and a variety in the same area, it will do just as well for my argument. Such certainly do exist. They are fertile together, and yet each maintains itself tolerably distinct. How can this be, if there is no disinclination to crossing? My belief certainly is that number of offspring is not so important an element in keeping up population of a species as supply of food and other favourable conditions, because the numbers of a species constantly vary greatly in different parts of its area, whereas the average number of offspring is not a very variable element.

However, I will say no more but leave the problem as insoluble, only fearing that it will become a formidable weapon in the hands of the enemies of Natural Selection.

While writing a few pages on the northern alpine forms of plants on the Java mountains I wanted a few cases to refer to like Teneriffe, where there are no northern forms, and scarcely any alpine. I expected the volcanoes of Hawaii would be a good case, and asked Dr. Seeman about them. It seems a man has lately published a list of Hawaiian plants, and the mountains swarm with European alpine genera and some species ! ${ }^{\prime}$ Is not this most extraordinary and a puzzler ? They are, I believe, truly oceanic

1 "This turns out to be inaccurate, or greatly exaggerated. There are no true alpines, and the European genera are comparatively few. See my 'Island Life,' p. 323."-A. R. W. 


\section{The Wallace-Darwin Correspondence}

islands in the absence of mammals and the extreme poverty of birds and insects, and they are within the tropics. Will not that be a hard nut for you when you come to treat in detail on geographical distribution?

I enclose Seeman's note, which please return when you have copied the list, if of any use to you.

Many thanks for your carte, which I think very good. The large one had not arrived when $I$ was in town last week.

Sir C. Lyell's chapter on Oceanic Islands I think very good.-Believe me, dear Darwin, yours very faithfully,

ALFRED R. WALLACE.

Down, Bromley, Kent, S.E. April 9, 1868.

My dear Wallace,-You allude in your note to several points which I should much enjoy discussing with you did time and strength permit. I know Dr. Seeman is a good botanist, but I most strongly advise you to show the list to Hooker before you make use of the materials in print. Hooker seems much overworked, and is now gone a tour, but I suppose you will be in town before very long, and could see him. The list is quite unintelligible to me; it is not pretended that the same species exist in the Sandwich Islands and Arctic regions; and as far as the genera are concerned, I know that in almost every one of them species inhabit such countries as Florida, North Africa, New Holland, etc. Therefore thesę genera seem to me almost mundane, and their presence in the Sandwich Islands will not, as I suspect in my ignorance, show any relation to the Arctic regions. The Sandwich Islands, though I have never considered them much, have long been a sore perplexity to me: they are eminently oceanic in position and productions; they have long been separated from each other; and there are only slight signs 


\section{Alfred Russel Wallace}

of subsidence in the islets to the westward. I remember, however, speculating that there must have been some immigration during the glacial period from North America or Japan; but I cannot remember what my grounds were. Some of the plants, I think, show an affinity with Australia. I am very glad that you like Lyell's chapter on Oceanic Islands, for I thought it one of the best in the part which I have read. If you do not receive the big photo of me in due time, let me hear.-Yours very sincerely,

Ch. Darwin.

The following refers to Wallace's article, "A Theory of Birds' Nests," in Andrew Murray's Journal of Travel, i. 73. He here treats in fuller detail the view already published in the Westminster Review for July, 1867, p. 38. The rule which Wallace believes, with very few exceptions, to hold good is, "that when both sexes are of strikingly gay and conspicuous colours, the nest is . . . such as to conceal the sitting bird; while, whenever there is a striking contrast of colours, the male being gay and conspicuous, the female dull and obscure, the nest is open and the sitting bird exposed to view." At this time Wallace allowed considerably more influence to sexual selection (in combination with the need of protection) than in his later writings. See his letter to Darwin of July 23, 1877 (p. 298), which fixes the period at which the change in his views occurred. He finally rejected Darwin's theory that colours " have been developed by the preference of the females, the more ornamented males becoming the parents of each successive generation." (See "Darwinism," 1889, p. 285.)

Down, Bromley, Kent, S.E. April 15, 1868.

My dear Wallace,-I have been deeply interested by your admirable article on Birds' Nests. I am delighted to see that we really differ very little-not more than two men almost always will. You do not lay much or any stress on new characters spontaneously appearing in one 212 


\section{The Wallace-Darwin Correspondence}

sex (generally the male) and being transmitted exclusively, or more commonly only in excess, to that sex. I, on the other hand, formerly paid far too little attention to protection. I had only a glimpse of the truth. But even now I do not go quite as far as you. I cannot avoid thinking rather more than you do about the exceptions in nesting to the rule, especially the partial exceptions, i.e. when there is some little difference between the sexes in species which build concealed nests. I am now quite satisfied about the incubating males; there is so little difference in conspicuousness between the sexes. I wish with all my heart I could go the whole length with you. You seem to think that such birds probably select the most beautiful females: I must feel some doubt on this head, for $I$ can find no evidence of it. Though $I$ am writing so carping a note, I admire the article thoroughly.

And now I want to ask a question. When female butterflies are more brilliant than their males, you believe that they have in most cases, or in all cases, been rendered brilliant so as to mimic some other species and thus escape danger. But can you account for the males not having been rendered equally brilliant and equally protected ? Although it may be most for the welfare of the species that the female shouid be protected, yet it would be some advantage, certainly no disadvantage, for the unfortunate male to enjoy an equal immunity from danger. For my part, I should say that the female alone had happened to vary in the right manner, and that the beneficial variations had been transmitted to the same sex alone. Believing in this, I can see no improbability (but from analogy of domestic animals a strong probability) : the variations leading to beauty must often have occurred in the males alone, and been transmitted to that sex alone. Thus I should account in many. cases for the greater beauty of the male over the female, 


\section{Alfred Russel Wallace}

without the need of the protective principle. I should be grateful for an answer on this point.

I hope that your Eastern book progresses well.-My dear Wallace, yours sincerely,

C. Darwin.

Sir Clifford Allbutt's view, referred to in the following letter, probably had reference to the fact that the spermcell goes, or is carried, to the germ-cell, never vice versa. In this letter Darwin gives the reason for the "law" referred to. Wallace has been good enough to supply the following note (May 27, 1902): "It was at this time that my paper on 'Protective Resemblance' first appeared in the Westminster Review, in which I adduced the greater, or, rather, the more continuous, importance of the female (in the lower animals) for the race, and my 'Theory of Birds' Nests' (Journal of Travel and Natural History, No. 2), in which I applied this to the usually dull colours of female butterflies and birds. It is to these articles, as well as to my letters, that Darwin chiefly refers."

Dowo, Bromley, Kent, S.E. April 30, 1868.

My dear Wallace,-Your letter, like so many previous ones, has interested me much. Dr. Allbutt's view occurred to me some time ago, and I have written a short discussion on it. It is, I think, a remarkable law, to which I have found no exception. The foundation lies in the fact that in many cases the eggs or seeds require nourishment and protection by the mother-form for some time after impregnation. Hence the spermatozoa and antherozoids travel in the lower aquatic animals and plants to the female, and pollen is borne to the female organ. As organisms rise in the scale it seems natural that the male should carry the spermatozoa to the females in his own body. As the male is the searcher he has received and gained more eager passions than the female; and, very differently from you, I look at this as one great diff- 


\section{The Wallace-Darwin Correspondence}

culty in believing that the males select the more attractive females; as far as I can diseover they are always ready to seize on any female, and sometimes on many females. Nothing would please me more than to find evidence of males selecting the more attractive females [? in pigeons ${ }^{1}$ ] :

I have for months been trying to persuade myself of this. There is the case of man in favour of this belief, and I know in hybrid [lizards' ${ }^{1}$ ] unions of males preferring particular females, but alas! not guided by colour. Perhaps I may get more evidence as I wade through my twenty years' mass of notes.

I am not shaken about the female protected butterflies : I will grant (only for argument) that the life of the male is of very little value; I will grant that the males do not vary; yet why has not the protective beauty of the female been transferred by inheritance to the male? The beauty would be a gain to the male, as far as we can see, as a protection; and I cannot believe that it would be repulsive to the female as she became beautiful. But we shall never convince each other. I sometimes marvel how truth progresses, so difficult is it for one man to convince another unless his mind is vacant. Nevertheless, I myself to a certain extent contradict my own remark; for $I$ believe far more in the importance of protection than $I$ did before reading your articles.

I do not think you lay nearly stress enough in your articles on what you admit in your letter, viz. "there seems to be some production of vividness . . . of colour in the male independent of protection." This I am making a chief point; and have come to your conclusion so far that $I$ believe that intense colouring in the female sex is often checked by being dangerous.

That is an excellent remark of yours about no known 1 "In pigeons" and "lizards" inserted by A. R. W. 


\section{Alfred Russel Wallace}

case of the male alone assuming protective colours; but in the cases in which protection has been gained by dull colours, I presume that sexual selection would interfere with the male losing his beauty. If the male alone had acquired beauty as a protection, it would be most readily overlooked, as males are so often more beautiful than their females. Moreover, I grant that the loss of the male is somewhat less precious and thus there would be less rigorous selection with the male, so he would be less likely to be made beautiful through Natural Selection for protection. (This does not apply to sexual selection, for the greater the excess of males and the less precious their lives, so much the better for sexual selection.) But it seems to me a good argument, and very good if it could be thoroughly established.-Yours most sincerely,

C. DARWIN.

I do not know whether you will care to read this scrawl.

P.S.-I heard yesterday that my photograph had been sent to your London address-Westbourne Grove.

Down, Bromley, Kent, S.E. May 5, 1868.

My dear Wallace,-I am afraid I have caused you a great deal of trouble in writing to me at such length. I am glad to say that I agree almost entirely with your summary, except that I should put sexual selection as an equal or perhaps as even a more important agent in giving colour than natural selection for protection. As I get on in my work I hope to get clearer and more decided ideas. Working up from the bottom of the scale $I$ have as yet only got to fishes. What I rather object to in your articles is that I do not think anyone would infer from them that you place sexual selection even as high as No. 4 in your sum. mary. It was very natural that you should give only a 


\section{The Wallace-Darwin Correspondence}

line to sexual selection in the summary to the Westminster Review, but the result at first to my mind was that you attributed hardly anything to its power. In your penultimate note you say: "In the great mass of cases in which there is great differentiation of colour between the sexes, I believe it is due almost wholly to the need of protection to the female." Now, looking to the whole animal kingdom I can at present by no means admit this view; but pray do not suppose that because I differ to a certain extent, I do not thoroughly admire your several papers and your admirable generalisation on birds' nests. With respect to this latter point, however, although following you, I suspect that I shall ultimately look at the whole case from a rather different point of view.

You ask what $I$ think about the gay-coloured females of Pieris : ${ }^{1} I$ believe I quite follow you in believing that the colours are wholly due to mimicry; and I further believe that the male is not brilliant from not having received through inheritance colour from the female, and from not himself having varied; in short, that he has not been influenced by Selection.

I can make no answer with respect to the elephants. With respect to the female reindeer, $I$ have hitherto looked at the horns simply as the consequence of inheritance not having been limited by sex.

Your idea about colour being concentrated in the smaller males seems good, and I presume that you will not object to my giving it as your suggestion.-Believe me, my dear Wallace, with many thanks, yours very sincerely,

Ch. Darwin.

Wallace's more recent views on the question of Natural Selection and Sterility may be found in a note written by

- See Westminster Review, July, 1867, p. 37. 


\section{Alfred Russel Wallace}

him in 1899: "When writing my 'Darwinism' and coming again to the consideration of the problem of the effect of Natural Selection in accumulating variations in the amount of sterility between varieties or incipient species, twenty years later, I became more convinced than I was when discussing with Darwin, of the substantial accuracy of my argument. Recently a correspondent who is both a naturalist and a mathematician has pointed out to me a slight error in my calculation at p. 183 (which does not, however, materially affect the result) disproving the physiological selection of the late Dr. Romanes, but he can see no fallacy in my argument as to the power of Natural Selection to increase sterility between incipient species, nor, so far as I am aware, has anyone shown such fallacy to exist.

"On the other points on which I differed from Mr. Darwin in the foregoing discussion-the effect of high fertility on population of a species, etc.-I still hold the views I then expressed, but it would be out of place to attempt to justify them here."-A. R. W.

9 St. Mark's Crescent, N.W. August 16, [1868 ?].

Dear Darwin,-I ought to have written before to thank you for the copies of your paper on "Primula" and on "Cross Unions of Dimorphic Plants, etc." The latter is particularly interesting, and the conclusion most important; but I think it makes the difficulty of how these forms, with their varying degres of sterility, originated, greater than ever. If Natural Selection could not accumulate varying degrees of sterility for the plant's benefit, then how did sterility ever come to be associated with one cross of a trimorphic plant rather than another ? The difficulty seems to be increased by the consideration that the advantage of a cross with a distinct individual is gained just as well by illegitimate as by legitimate unions. By what means, then, did illegitimate unions ever become sterile? It would seem a far simpler way for each plant's pollen 


\section{The Wallace-Darwin Correspondence}

to have acquired a prepotency on another individual's stigma over that of the same individual, without the extraordinary complication of three differences of structure and eighteen different unions with varying degrees of sterility!

However, the fact remains an excellent answer to the statement that sterility of hybrids proves the absolute distinctness of the parents.

I have been reading with great pleasure Mr. Bentham's last admirable address, ${ }^{1}$ in which he so well replies to the gross misstatements of the Athencum; and also says a word in favour of pangenesis. I think we may now congratulate you on having made a valuable convert, whose opinions on the subject, coming so late and being evidently so well considered, will have much weight.

I am going to Norwich on Tuesday to hear Dr. Hooker, who I hope will boldly promulgate "Darwinianism" in his address. Shall we have the pleasure of seeing you there ?

I am engaged in negotiations about my book.

Hoping you are well and getting on with your next volumes, believe me yours very faithfully,

Alfred R. Waltace.

Freshwater, Isle of Wight. August 19, 1868.

My dear Wallace,-Thanks for your note. I did sometimes think of going to Norwich, for I should have very much liked it, but it has been quite out of the question. We have been here for five weeks for a change, and it has done me some little good; but $I$ have been forced to live the life of a drone, and for a month before leaving home I was unable to do anything and had to stop all work.

We return to Down to-morrow.

Hooker has been here for two or three days, so that I 1 Proc. Linn. Soc., 1867-8, p. 57. 


\section{Alfred Russel Wallace}

have had much talk about his Address. I am glad that you will be there.

It is real good news that your book is so advanced that you are negotiating about its publication.

With respect to dimorphic plants : it is a great puzzle, but I fancy I partially see my way-too long for a letter and too speculative for publication. The groundwork of the acquirement of such peculiar fertility (for what you say about any other distinct individual being, as it would appear, sufficient, is very true) rests on the stamens and pistil having varied first in relative length, as actually occurs irrespective of dimorphism, and the peculiar kind of fertility characteristic of dimorphic and the trimorphic plants having been secondarily acquired. Pangenesis makes very few converts : G. H. Lewes is one.

I had become, before my nine weeks' horrid interruption of all work, extremely interested in sexual selection and was making fair progress. In truth, it has vexed me much to find that the further I get on, the more I differ from you about the females being dull-coloured for protection. I can now hardly express myself as strongly even as in the "Origin." This has much decreased the pleasure of my work.

In the course of September, if I can get at all stronger, I hope to get Mr. J. Jenner Weir (who has been wonderfully kind in giving me information) to pay me a visit, and $I$ will then write for the chance of your being able to come and, I hope, bring with you Mrs. Wallace. If I could get several of you together, it would be less dull for you, for of late I have found it impossible to talk with any human being for more than half an hour, except on extraordinarily good days.-Believe me, my dear Wallace, ever yours sincerely,

Ch. Darwin. 


\section{The Wallace-Darwin Correspondence}

9 St. Mark's Crescent. August 30, [1868 ?].

Dear Darwin,-I was very sorry to hear you had been so unwell again, and hope you will not exert yourself to write me such long letters. Darwinianism was in the ascendant at Norwich (I hope you do not dislike the word, for we really must use it), and I think it rather disgusted some of the parsons, joined with the amount of advice they received from Hooker and Huxley. The worst of it is that there are no opponents left who know anything of natural history, so that there are none of the good discussions we used to have. G. H. Lewes seems to me to be making a great mistake in the Fortnightly, advocating many distinct origins for different groups, and even, if I understand him, distinct origins for some allied groups, just as the anthropologists do who make the red man descend from the orang, the black man from the chimpanzee-or rather the Malay and orang one ancestor, the negro and chimpanzee another. Vogt told me that the Germans are all becoming converted by your last book.

I am certainly surprised that you should find so much evidence against protection having checked the acquirement of bright colour in females; but I console myself by presumptuously hoping that I can explain your facts, unless they are derived from the very groups on which I chiefly rest-birds and insects. There is nothing necessarily requiring protection in females; it is a matter of habits. There are groups in which both sexes require protection in an exactly equal degree, and others (I think) in which the male requires most protection, and I feel the greatest confidence that these will ultimately support my view, although I do not yet know the facts they may afford.

Hoping you are in better health, believe me, dear Darwin, yours faithfully,

Alfred R. Wallace. 


\section{Alfred Russel Wallace $_{3}$}

9 St. Mark's Crescent, N.W.

Dear Darwin,-It will give me great pleasure to accept your kind invitation for next Saturday and Sunday, and my wife would very much like to come too, and will if possible. Unfortunately, there is a new servant coming that very day, and there is a baby at the mischievous age of a year and a quarter to be left in somebody's care; but I daresay it will be managed somehow.

I will drop a line on Friday to say if we are coming the time you mention.-Believe me yours very faithfully,

Alfred R. Wallace.

Friday.

My dear Darwin,-My wife has arranged to accompany me to-morrow, and we hope to be at Orpington Station at 5.44, as mentioned by you.-Very truly yours,

Alfred R. Wallace.

Down, Bromley, Kent, S.E. September 16, 1868.

My dear Wallace,-The beetles have arrived, and cordial thanks: I never saw such wonderful creatures in my life. I was thinking of something quite different. I shall wait till my son Frank returns, before soaking and examining them. I long to steal the box, but return it by this post, like a too honest man.

I am so much pleased about the male musk Callichroma; for by odd chance $I$ told Frank a week ago that next spring he must collect at Cambridge lots of Cerambyx moschatus, for as sure as life he would find the odour sexual!

You will be pleased to hear that I am undergoing severe distress about protection and sexual selection: this morning I oscillated with joy towards you; this evening $I$ have 


\section{The Wallace-Darwin Correspondence}

swung back to the old position, out of which I fear I shall never get.

I did most thoroughly enjoy my talk with you three gentlemen, and especially with you, and to my great surprise it has not knocked me up. Pray give my kindest remembrances to Mrs. Wallace, and if my wife were at home she would cordially join in this.-Yours very sincerely,

CH. DARWIN.

I have had this morning a capital letter from Walsh of Illinois; but details too long to give.

Among Wallace's papers was found the following draft of a letter of his to Darwin :

9 St. Mark's Crescent, N.W. September 18, 1868.

Dear Darwin,-The more I think of your views as to the colours of females, the more difficulty $I$ find in accepting them, and as you are now working at the subject $I$ hope it will not interrupt you to hear "counsel on the other side."

I have a "general" and a "special " argument to submit.

1. Female birds and insects are generally exposed to more danger than the male, and in the case of insects their existence is necessary for a longer period.

2. They therefore require in some way or other a special balance of protection.

3. Now, if the male and female were distinct species, with different habits and organisations, you would, I think, at once admit that a difference of colour serving to make that one less conspicuous which evidently required more protection than the other had been acquired by Natural Selection.

4. But you admit that variations appearing in one sex are transmitted (often) to that sex only : there is therefore 223 


\section{Alfred Russel Wallace}

nothing to prevent Natural Selection acting on the two sexes as if they were two species.

5. Your objection that the same protection would to a certain extent be useful to the male, seems to me utterly unsound, and directly opposed to your own doctrine so convincingly urged in the "Origin," "that Natural Selection never can improve an animal beyond its needs." So that admitting abundant variation of colour in the male, it is impossible that he can be brought by Natural Selection to resemble the female (unless her variations are always transmitted to him), because the difference of their colours is to balance the difference in their organisations and habits, and Natural Selection cannot give to the male more than is needed to effect that balance.

6. The fact that in almost all protected groups the females perfectly resemble the males shows, I think, a tendency to transference of colour from one sex to the other when this tendency is not injurious.

Or perhaps the protection is acquired because this tendency exists. I admit therefore in the case of concealed nests they [habits] may have been acquired for protection.

Now for the special case.

7. In the very weak-flying Leptalis both sexes mimic Heliconidæ.

8. In the much more powerful Papilio, Pieris, and Diadema it is generally the female only that mimics Danaida.

9. In these cases the females often acquire more bright and varied colours than the male. Sometimes, as in Pieris pyrrha, conspicuously so.

10. No single case is known of a male Papilio, Pieris, Diadema (or any other insect ?) alone mimicking a Danais, etc. 


\section{The Wallace-Darwin Correspondence}

11. But colour is more frequent in males, and varia. tions always seem ready for purposes of sexual or other selection.

12. The fair inference seems to be that given in proposition 5 of the general argument, viz. that each species and each sex can only be modified by selection just as far as is absolutely necessary, not a step farther. A male, being by structure and habits less exposed to danger and less requiring protection than the female, cannot have more protection given to it by Natural Selection, but a female must have some extra protection to balance the greater danger, and she rapidly acquires it in one way or another.

13. An objection derived from cases like male fish, which seem to require protection, yet having brighter colours, seems to me of no more weight than is that of the existence of many white and unprotected species of Leptalis to Bates's theory of mimicry, that only one or two species of butterflies perfectly resemble leaves, or that the instincts or habits or colours that seem essential to the preservation of one animal are often totally absent in an allied species.

Down, Bromley, Kent. September 23, 1868.

My dear Wallace,-I am very much obliged for all your trouble in writing me your long letter, which $\mathrm{I}$ will keep by me and ponder over. To answer it would require at least 200 folio pages! If you could see how often $I$ have rewritten some pages, you would know how anxious $I$ am to arrive as near as I can to the truth. We differ, I think, chiefly from fixing our minds perhaps too closely on different points, on which we agree: I lay great stress on what I know takes place under domestication: I think we start with different fundamental notions on inheritance. I find 


\section{Alfred Russel Wallace}

it most difficult, but not, I think, impossible, to see how, for instance, a few red feathers appearing on the head of a male bird, and which are at first transmitted to both sexes, could come to be transmitted to males alone; ${ }^{1}$ but I have no difficulty in making the whole head red if the few red feathers in the male from the first tended to be sexually transmitted. I am quite willing to admit that the female may have been modified, either at the same time or subsequently, for protection, by the accumulation of variations limited in their transmission to the female sex. I owe to your writings the consideration of this latter point. But I cannot yet persuade myself that females alone have often been modified for protection. Should you grudge the trouble briefly to tell me whether you believe that the plainer head and less bright colours of $q^{2}$ chaffinch, the less red on the head and less clean colours of $ᄋ$ goldfinch, the much less red on breast of $q$ bullfinch, the paler crest of goldencrest wren, etc., have been acquired by them for protection? I cannot think so; any more than I can that the considerable differences between $q$ and $\hat{\sigma}$ house-sparrow, or much greater brightness of $\hat{\sigma}$ Parus caruleus (both of which build under cover) than of \& Parus are related to protection. I even misdoubt much whether the less blackness of blackbird is for protection.

Again, can you give me reason for believing that the merest differences between female pheasants, the female Gallus bankiva, the female of black grouse, the pea-hen, female partridge, have all special reference to protection

1 It is not enough that females should be produced from the males with red feathers, which should be destitute of red feathers; but these females must have a latent tendency to produce such feathers, otherwise they would cause deterioration in the red head-feathers of their male ofispring. Such latent tendency would be shown by their producing the red feathers when old or diseased in their ovaria.

2 The symbols $\delta$; 9 stand for male and female respectively. 


\section{The Wallace-Darwin Correspondence}

under slightly different conditions? I of course admit that they are all protected by dull colours, derived, as I think, from some dull-ground progenitor; and I account partly for their difference by partial transference of colour from the male, and by other means too long to specify; but I earnestly wish to see reason to believe that each is specially adapted for concealment to its environment.

I grieve to differ from you, and it actually terrifies me, and makes me constantly distrust myself.

I fear we shall never quite understand each other. I value the cases of bright-coloured, incubating male fishes -and brilliant female butterflies, solely as showing that one sex may be made brilliant without any necessary transference of beauty to the other sex; for in these cases I cannot suppose that beauty in the other sex was checked by selection.

I fear this letter will trouble you to read it. A very short answer about your belief in regard to the $q$ finches and Gallinaceæ would suffice.-Believe me, my dear Wallace, yours very sincerely,

Ch. Darwin.

9 St. Mark's Crescent, N.W. September 27, 1868.

Dear Darwin,-Your view seems to be that variations occurring in one sex are transmitted either to that sex exclusively or to both sexes equally, or more rarely partially transferred. But we have every gradation of sexual colours from total dissimilarity to perfect identity. If this is explained solely by the laws of inheritance, then the colours of one or other sex will be always (in relation to their environment) a matter of chance. I cannot think this. I think Selection more powerful than laws of inheritance, of which it makes use, as shown by cases of two, three or four forms of female butterflies, all of which have, I have little doubt, been specialised for protection. 


\section{Alfred Russel Wallace}

To answer your first question is most difficult, if not impossible, because we have no sufficient evidence in individual cases of slight sexual difference, to determine whether the male alone has acquired his superior brightness by sexual selection, or the female been made duller by need of protection, or whether the two causes have acted. Many of the sexual differences of existing species may be inherited differences from parent forms who existed under different conditions and had greater or less need of protection.

I think I admitted before the general tendency (probably) of males to acquire brighter tints. Yet this cannot be universal, for many female birds and quadrupeds have equally bright tints.

I think the case of + Pieris pyrrha proves that females alone can be greatly modified for protection.

To your second question I can reply more decidedly. I do think the females of the Gallinaces you mention have been modified or been prevented from acquiring the brighter plumage of the male by need of protection. I know that the Gallus bankiva frequents drier and more open situations than the pea-hen of Java, which is found among grassy and leafy vegetation corresponding with the colours of the two. So the Argus pheasant, $f$ and $q$, are, I feel sure, protected by their tints corresponding to the dead leaves of the lofty forest in which they dwell, and the female of the gorgeous fire-back pheasant, Lophura viellottii, is of a very similar rich brown colour. I do not, however, at all think the question can be settled by individual cases, but only by large masses of facts.

The colours of the mass of female birds seem to me strictly analogous to the colours of both sexes of snipes, woodcocks, plovers, etc., which are undoubtedly protective.

Now, supposing, on your view, that the colours of a 


\section{The Wallace-Darwin Correspondence}

male bird become more and more brilliant by sexual selection, and a good deal of that colour is transmitted to the female till it becomes positively injurious to her during incubation and the race is in danger of extinction, do you not think that all the females who had acquired less of the male's bright colours or who themselves varied in a protective direction would be preserved, and that thus a good protective colouring would be acquired? If you admit that this could occur, and can show no good reason why it should not often occur, then we no longer differ, for this is the main point of my view.

Have you ever thought of the red wax-tips of the Bombycilla beautifully imitating the red fructification of lichens used in the nest, and therefore the females have it too ? Yet this is a very sexual-looking character.

We begin printing this week.-Yours very faithfully,

ALFRed R. WALLACE.

P.S.-Pray don't distress yourself on this subject. It will all come right in the end, and after all it is only an episode in your great work.-A. R. W.

9 St. Mark's Crescent, N.W. October 4, 1868.

Dear Darwin,-I should have answered your letter before, but have been very busy reading over my MSS. the last time before going to press, drawing maps, etc. etc.

Your first question cannot be answered, because we have not, in individual cases of slight sexual difference, sufficient evidence to determine how much of that difference is due to sexual selection acting on the male, how much to natural selection (protective) acting on the female, or how much of the difference may be due to inherited differences from ancestors who lived under different conditions. On your second question I can give an opinion. I do think the 


\section{Alfred Russel Wallace}

females of the Gallinaceæ you mention have been either modified, or prevented from acquiring much of the brighter plumage of the males, by the need of protection. I know that Gallus bankiva frequents drier and more open situations than Pavo muticus, which in Java is found among grassy and leafy vegetation corresponding with the colours of the two females. So the Argus pheasants, male and female, are, I feel sure, protected by their tints corresponding to dead leaves of the dry lofty forests in which they dwell; and the female of the gorgeous fire-back pheasant, Lophura viellottii, is of a very similar rich brown colour.

These and many other colours of female birds seem to me exactly analogous to the colours of both sexes in such groups as the snipes, woodcocks, plovers, ptarmigan, desert birds, Arctic animals, greenbirds.

[The second page of this letter has been torn off. This letter and that of September 27 appear both to answer the same letter from Darwin. The last page of this or of another letter was placed with it in the portfolio of letters; it is now given.]

I am sorry to find that our difference of opinion on this point is a source of anxiety to you.

Pray do not let it be so. The truth will come out at last, and our difference may be the means of setting others to work who may set us both right.

After all, this question is only an episode (though an important one) in the great question of the origin of species, and whether you or $I$ are right will not at all affect the main doctrine-that is one comfort.

I hope you will publish your treatise on Sexual Selection as a separate book as soon as possible, and then while you are going on with your other work, there will no 


\section{The Wallace-Darwin Correspondence}

doubt be found someone to battle with me over your facts, on this hard problem.

With best wishes and kind regards to Mrs. Darwin and all your family, believe me, dear Darwin, yours very faithfully,

AlFRed R. WALLACE.

Down, Bromley, Kent, S.E. October 6, 1868.

My dear Wallace,--Your letter is very valuable to me, and in every way very kind. I will not inflict a long answer, but only answer your queries. There are breeds (viz. Hamburgh) in which both sexes differ much from each other and from both sexes of G. bankiva; and both sexes are kept constant by selection.

The comb of Spanish ${ }^{t}$ has been ordered to be upright and that of Spanish $q$ to lop over, and this has been effected. There are sub-breeds of game fowl, with os very distinct and $\delta^{t} \mathrm{~s}$ almost identical; but this apparently is the result of spontaneous variation without special selection.

I am very glad to hear of the case of $q$ birds of paradise.

I have never in the least doubted the possibility of modifying female birds alone for protection; and I have long believed it for butterflies: I have wanted only evidence for the females alone of birds having had their colours modified for protection. But then I believe that the variations by which a female bird or butterfly could get or has got protective colouring have probably from the first been variations limited in their transmission to the female sex; and so with the variations of the male, where the male is more beautiful than the female, I believe the variations were sexually limited in their transmission to the males. I am delighted to hear that you have been hard at work on your MS.-Yours most sincerely,

Gre. Darwin. 


\section{Alfred Russel Wallace}

9 St. Mark's Crescent, N.W. January 20, 1869.

Dear Darwin,-It will give me very great pleasure if you will allow me to dedicate my little book of Malayan Travels to you, although it will be far too small and unpretending a work to be worthy of that honour. Still, I have done what I can to make it a vehicle for communicating a taste for the higher branches of Natural History, and I know that you will judge it only too favourably. We are in the middle of the second volume, and if the printers will get on, shall be out next month.

Have you seen in the last number of the Quarterly Journal of Science the excellent remarks on Fraser's article on Natural Selection failing as to Man? In one page it gets to the heart of the question, and $I$ have written to the editor to ask who the author is.

My friend Spruce's paper on Palms is to be read tomorrow evening at the Linnean. He tells me it contains a discovery which he calls "alteration of function." He found a clump of Geonema all of which were females, and the next year the same clump were all males! He has found other facts analogous to this, and I have no doubt the subject is one that will interest you.

Hoping you are pretty well and are getting on steadily with your next volumes, and with kind regards to Mrs. Darwin and all your circle, believe me, dear Darwin, yours very faithfully,

Alfred R. WALlaCE.

P.S.-Have you seen the admirable article in the Guardian (!) on Lyell's " Principles" ? It is most excellent and liberal. It is written by the Rev. Geo. Buckle, of Tiverton Vicarage, Bath, whom I met at Norwich and found a thoroughly scientific and liberal parson. Perhaps you have heard that $I$ have undertaken to write an article for the Quarterly (!) on the same subject, to make 


\section{The Wallace-Darwin Correspondence}

up for that on "Modern Geology" last year not mention. ing Sir C. Lyell.

Really, what with the Tories passing Radical Reform Bills and the Church periodicals advocating Darwinianism, the millennium must be at hand.-A. R. W.

Down, Bromley, Kent, S.E. January 22, 1869.

My dear Wallace,-Your intended dedication pleases me much and $I$ look at it as a great honour, and this is nothing more than the truth. I am glad to hear, for Lyell's sake and on general grounds, that you are going to write in the Quarterly. Some little time ago I was actually wishing that you wrote in the Quarterly, as I knew that you occasionally contributed to periodicals, and I thought that your articles would thus be more widely read.

Thank you for telling me about the Guardian, which I will borrow from Lyell. I did note the article in the Quarterly Journal of Science and put it aside to read again with the articles in Fraser and the Spectator.

$I$ have been interrupted in my regular work in prepar. ing a new edition" of the "Origin," which has cost me much labour, and which I hope I have considerably im. proved in two or three important points. I always thought individual differences more important than single variations, but now I have come to the conclusion that they are of paramount importance, and in this $I$ believe I agree with you. Fleeming Jenkin's arguments have convinced me. ${ }^{2}$

I heartily congratulate you on your new book being so nearly finished.-Believe me, my dear Wallace, yours very sincerely,

Ch. Darwin.

1 The fifth. Explained in letter of February 2, 1869. See p. 234. 


\section{Alfred Russel Wallace}

9 St. Mark's Crescent, N.W. January 30, 1869.

Dear Darwin,-Will you tell me where are Fleeming Jenkin's arguments on the importance of single variation? Because I at present hold most strongly the contrary opinion, that it is the individual differences or general variability of species that enables them to become modified and adapted to new conditions.

Variations or "sports" may be important in modifying an animal in one direction, as in colour for instance, but how it can possibly work in changes requiring coordination of many parts, as in Orchids for example, I cannot conceive. And as all the more important structural modifications of animals and plants imply much coordination, it appears to me that the chances are millions to one against individual variations ever coinciding so as to render the required modification possible. However, let me read first what has convinced you.

You may tell Mrs. Darwin that I have now a daughter.

Give my kind regards to her and all your family.-Very truly yours,

ALFRED R. WALLACE.

Down, Bromley, Kent, S.E. February 2, 1869.

My dear Wallace,-I must have expressed myself atrociously ; I meant to say exactly the reverse of what you have understood. F. Jenkin argued in the North British Review ${ }^{1}$ against single variations ever being perpetuated, and has convinced me, though not in quite so broad a manner as here put. I always thought individual differences more important, but $I$ was blind and thought that single variations might be preserved much oftener than $I$ now see is possible or probable. I mentioned this in my former note merely because I believed that you had come to similar

1 June, 1867. 


\section{The Wallace-Darwin Correspondence}

conclusions, and I like much to be in accord with you. I believe I was mainly deceived by single variations offering such simple illustrations, as when man selects.

We heartily congratulate you on the birth of your little daughter.-Yours very sincerely,

C. Darwin.

Down, Bromley, Kent, S.E. March 5, 1869.

My dear Wallace,-I was delighted at receiving your book $^{1}$ this morning. The whole appearance and the illustrations with which it [is] so profusely ornamented are quite beautiful. Blessings on you and your publisher for having the pages cut and gilded.

As for the dedication, putting quite aside how far I deserve what you say, it seems to me decidedly the best expressed dedication which I have ever met.

The reading will probably last me a month, for I dare not have it read aloud, as I know that it will set me thinking.

I see that many points will interest me greatly. When I have finished, if I have anything particular to say, I will write again. Accept my cordial thanks. The dedication is a thing for my children's children to be proud of.-Yours most sincerely,

Ch. Darwin.

9 St. Mark's Crescent, N.W. March 10, 1869.

Dear Darwin,-Thanks for your kind note. I could not persuade Mr. Macmillan to cut more than twenty-five copies for my own friends, and he even seemed to think this a sign of most strange and barbarous taste.

Mr. Weir's paper on the kinds of larvæ, etc., eaten or rejected by insectivorous birds was read at the last meeting of the Entomological Society and was most interesting and satisfactory. His observations and experiments, so far 


\section{Alfred Russel Wallace}

as they have yet gone, confirm in every instance my hypothetical explanation of the colours of caterpillars. He finds that all nocturnal-feeding obscure-coloured caterpillars, all green and brown and mimicking caterpillars, are greedily. eaten by almost every insectivorous bird. On the other hand, every gaily coloured, spotted or banded species, which never conceal themselves, and all spiny and hairy kinds, are invariably rejected, either without or after trial. He has also come to the curious and rather unexpected conclusion, that hairy and spiny caterpillars are not protected by their hairs, but by their nauseous taste, the hairs being merely an external mark of their uneatableness, like the gay colours of others. He deduces this from two kinds of facts: (1) that very young caterpillars before the hairs are developed are equally rejected, and (2) that in many cases the smooth pupæ and even the perfect insects of the same species are equally rejected.

His facts, it is true, are at present not very numerous, but they all point one way. They seem to me to lend an immense support to my view of the great importance of protection in determining colour, for it has not only prevented the eatable species from ever acquiring bright colours, spots, or markings injurious to them, but it has also conferred on all the nauseous species distinguishing marks to render their uneatableness more protective to them than it would otherwise be. When you have read my book I shall be glad of any hints for corrections if it comes to another edition. I was horrified myself by coming accidentally on several verbal inelegancies after all my trouble in correcting, and I have no doubt there are many more important errors.-Believe me, dear Darwin, yours very truly,

ALFRED R. WaLLACE. 


\section{The Wallace-Darwin Correspondence}

Down, Bromley, Kent, S.E. March 22, 1869.

My dear Wallace,-I have finished your book. ${ }^{1}$ It seems to me excellent, and at the same time most pleasant to read. That you ever returned alive is wonderful after all your risks from illness and sea voyages, especially that most interesting one to Waigiou and back. Of all the impressions which I have received from your book, the strongest is that your perseverance in the cause of science was heroic. Your descriptions of catching the splendid butterflies have made me quite envious, and at the same time have made me feel almost young again, so vividly have they brought before my mind old days when I collected, though I never made such cap. tures as yours. Certainly collecting is the best sport in the world. I shall be astonished if your book has not a great success; and your splendid generalisations on geographica] distribution, with which I am familiar from your papers, will be new to most of your readers. I think I enjoyed most the Timor case, as it is best demonstrated; but perhaps Celebes is really the most valuable. I should prefer looking at the whole Asiatic continent as having formerly been more African in its fauna, than admitting the former existence of a continent across the Indian Ocean. Decaisne's paper on the flora of Timor, in which he points out its close relation to that of the Mascarene Islands, supports your view. On the other hand, I might advance the giraffes, etc., in the Sewalik deposits. How I wish someone would collect the plants of Banca! The puzzle of Java, Sumatra and Borneo is like the three geese and foxes: I have a wish to extend Malacca through Banca to part of Java and thus make three parallel peninsulas, but $I$ cannot get the geese and foxes across the river.

Many parts of your book have interested me much : I 1 "Malay Archipelago." 


\section{Alfred Russel Wallace}

always wished to hear an independent judgment about the Rajah Brooke, and now I have been delighted with your splendid eulogium on him.

With respect to the fewness and inconspicuousness of the flowers in the tropics, may it not be accounted for by the hosts of insects, so that there is no need for the flowers to be conspicuous? As, according to Humboldt, fewer plants are social in the tropical than in the temperate regions, the flowers in the former would not make so great a show.

In your note you speak of observing some inelegancies of style. I notice none. All is as clear as daylight. I have detected two or three errata.

In Vol. I. you write londiacus : is this not an error?

Vol. II., p. 236 : for western side of Aru read eastern.

Page 315: Do you not mean the horns of the moose? For the elk has not palmated horns.

I have only one criticism of a general nature, and I am not sure that other geologists would agree with me: you repeatedly speak as if the pouring out of lava, etc., from volcanoes actually caused the subsidence of an adjoining area. I quite agree that areas undergoing opposite movements are somehow connected; but volcanic outbursts must, I think, be looked at as mere accidents in the swelling up of a great dome or surface of plutonic rocks; and there seems no more reason to conclude that such swelling or elevation in mass is the cause of the subsidence than that the subsidence is the cause of the elevation; which latter view is indeed held by some geologists. I have regretted to find so little about the habits of the many animals which you have seen.

In Vol. II., p. 399, I wish I could see the connection between variations having been first or long ago selected, and their appearance at an earlier age in birds of paradise 


\section{The Wallace-Darwin Correspondence}

than the variations which have subsequently arisen and been selected. In fact, I do not understand your explanation of the curious order of development of the ornaments of these birds.

Will you please to tell me whether you are sure that the female Casuarius (Vol. II., p. 150) sits on her eggs as well as the male?-for, if I am not mistaken, Bartlett told me that the male alone, who is less brightly coloured about the neck, sits on the eggs. In Vol. II., p. 255, you speak of male savages ornamenting themselves more than the women, of which $I$ have heard before; now, have you any notion whether they do this to please themselves, or to excite the admiration of their fellow-men, or to please the women, or, as is perhaps probable, from all three motives?

Finally, let me congratulate you heartily on having written so excellent a book, full of thought on all sorts of subjects. Once again, let me thank you for the very great honour which you have done me by your dedication. -Believe me, my dear Wallace, yours very sincerely,

Ch. Darwin.

Vol. II., p. 455: When in New Zealand I thought the inhabitants a mixed race, with the type of Tahiti preponderating over some darker race with more frizzled hair; and now that the stone instruments [have] revealed the existence of ancient inhabitants, is it not probable that these islands were inhabited by true Papuans? Judging from descriptions the pure Tahitans must differ much from your Papuans.

The reference in the following letter is to Wallace's review, in the April number of the Quarterly, of Lyell's "Principles of Geology" (tenth edition), and of the sixth edition of the "Elements of Geology." Wallace points out that here for the first time Sir C. Lyell gave up his opposition to Evolution; and this leads Wallace to give 


\section{Alfred Russel Wallace}

a short account of the views set forth in the "Origin of Species." In this article Wallace makes a definite statement as to his views on the evolution of man, which were opposed to those of Darwin. He upholds the view that the brain of man, as well as the organs of speech, the hand and the external form, could not have been evolved by Natural Selection (the "child" he is supposed to "murder"). At p. 391 he writes: "In the brain of the lowest savages and, as far as we know, of the prehistoric races, we have an organ ... little inferior in size and complexity to that of the highest types. . . . But the mental requirements of the lowest savages, such as the Australians or the Andaman Islanders, are very little above those of many animals. . . How then was an organ developed far beyond the needs of its possessor? Natural Selection could only have endowed the savage with a brain a little superior to that of an ape, whereas he actually possesses one but very little inferior to that of the average members of our learned societies."

This passage is marked in Darwin's copy with a triply underlined "No," and with a shower of notes of exclamation. It was probably the first occasion on which he realised the extent of this great and striking divergence in opinion between himself and his colleague. He had, however, some indication of it in Wallace's paper on Man in the Anthro. pological Review, 1864, referred to in his letter to Wallace of May 28, 1864, and again in that of April 14, 1869.

Down, Bromley, Kent, S.E. March 27, 1869.

My dear Wallace,-I must send a line to thank you, but this note will require no answer. This very morning after writing I found that "elk" was used for "moose" in Sweden, but $I$ had been reading lately about elk and moose in North America.

As you put the case in your letter, which $I$ think differs somewhat from your book, I am inclined to agree, and had thought that a feather could hardly be increased in length 


\section{The Wallace-Darwin Correspondence}

until it had first grown to full length, and therefore it would be increased late in life and transmitted to a corresponding age. But the Crossoptilon pheasant, and even the common pheasant, show that the tail feathers can be developed very early.

Thanks for other facts, which I will reflect on when I go again over my MS.

I read all that you said about the Dutch Government with much interest, but I do not feel I know enough to form any opinion against yours.

I shall be intensely curious to read the Quarterly: I hope you have not murdered too completely your own and my child.

I have lately, i.e. in the new edition of the "Origin," I been moderating my zeal, and attributing much more to mere useless variability. I did think I would send you the sheet, but I daresay you would not care to see it, in which I discuss Nägeli's essay on Natural Selection not affecting characters of no functional importance, and which yet are of high classificatory importance.

Hooker is pretty well satisfied with what I have said on this head. It will be curious if we have hit on similar conclusions. You are about the last man in England who would deviate a hair's breadth from his conviction to please any editor in the world.-Yours very sincerely,

Ch. Darwin.

P.S.-After all, I have thought of one question, but if I receive no answer I shall understand that (as is probable) you have nothing to say. I have seen it remarked that the men and women of certain tribes differ a little in shade or tint; but have you ever seen or heard of any difference in tint between the two sexes which did not appear to follow from a difference in habits of life?

1 The fifth edition, pp. 150-7. 


\section{Alfred Russel Wallace}

Down, Bromley, Kent, S.E. April 14, 1869.

My dear Wallace,-I have been wonderfully interested by your article, ${ }^{1}$ and I should think Lyell will be much gratified by it. I declare if I had been editor and had the power of directing you I should have selected for discussion the very points which you have chosen. I have often said to younger geologists (for I began in the year 1830) that they did not know what a revolution lyell had effected; nevertheless, your extracts from Cuvier have quite astonished me.

Though not able really to judge, I am inclined to put more confidence in Croll than you seem to do; but $I$ have been much struck by many of your remarks on degradation.

Thomson's views of the recent age of the world have been for some time one of $\mathrm{my}$, sorest troubles, and so I have been glad to read what you say. Your exposition of Natural Selection seems to me inimitably good; there never lived a better expounder than you.

I was also much pleased at your discussing the difference between our views and Lamarck's. One sometimes sees the odious expression, "Justice to myself compels me to say, etc.," but you are the only man I ever heard of who persistently does himself an injustice and never demands justice. Indeed, you ought in the review to have alluded to your paper in the Linnean Journal, and I feel sure all our friends will agree in this, but you cannot "Burke" yourself, however much you may try, as may be seen in half the articles which appear.

I was asked but the other day by a German professor for your paper, which I sent him. Altogether, I look at your article as appearing in the Quarterly as an immense triumph for our cause. I presume that your remarks on Man are those to which you alluded in your note.

1 In the Quarterly Review, April, 1869. 


\section{The Wallace-Darwin Correspondence}

If you had not told me I should have thought that they had been added by someone else. As you expected, I differ grievously from you, and I am very sorry for it.

I can see no necessity for calling in an additional and proximate cause in regard to Man. But the subject is too long for a letter.

I have been particularly glad to read your discussion, because $I$ am now writing and thinking much about Man.

I hope that your Malay book sells well. I was extremely pleased with the article in the $Q . J$. of Science, inasmuch as it is thoroughly appreciative of your work. Alas! you will probably agree with what the writer says about the uses of the bamboo.

I hear that there is also a good article in the Saturday Review, but have heard nothing more about it.-Believe me, my dear Wallace, yours ever sincerely,

Ch. Darwin.

P.S.-I have had a baddish fall, my horse partly rolling over me; but I am getting rapidly well.

9 St. Mark's Crescent, N.W. April 18, 1869.

Dear Darwin,-I am very glad you think I have done justice to Lyell, and have also well "exposed" (as a Frenchman would say) Natural Selection. There is nothing I like better than writing a little account of it, and trying to make it clear to the meanest capacity.

The "Croll" question is awfully difficult. I had gone into it more fully, but the Editor made me cut out eight pages.

I am very sorry indeed to hear of your accident, but trust you will soon recover and that it will leave no bad effects.

I can quite comprehend your feelings with regard to my " unscientific" opinions as to Man, because a few years back 


\section{Alfred Russel Wallace}

I should myself have looked at them as equally wild and uncalled for. I shall look with extreme interest for what you are writing on Man, and shall give full weight to any. explanations you can give of his probable origin. My opinions on the subject have been modified solely by the consideration of a series of remarkable phenomena, physical and mental, which $I$ have now had every opportunity of fully testing, and which demonstrate the existence of forces and influences not yet recognised by science. This will, I know, seem to you like some mental hallucination, but as I can assure you from personal communication with them, that Robert Chambers, Dr. Norris of Birmingham, the wellknown physiologist, and C. F. Varley, the well-known electrician, who have all investigated the subject for years, agree with me both as to the facts and as to the main inferences to be drawn from them, I am in hopes that you will suspend your judgment for a time till we exhibit some corroborative symptoms of insanity.

In the meantime I can console you by the assurance that I don't agree with the $Q$. $J$. of Science about bamboo, and that I see no cause to modify any of my opinions expressed in my article on the "Reign of Law."-Believe me yours very faithfully,

ALFRED R. Wallace.

9 St. Mark's Crescent, N.W. June 23, 1869.

Dear Darwin,-Thank you very much for the copy of your fifth edition of the "Origin." I thave not yet read all the additions, but those I have looked at seem very interesting, though somewhat brief, but I suppose you are afraid of its great and rapid growth.

A difficult sexual character seems to me the plumules or battledore scales on the wings of certain families and genera of butterflies, almost invariably changing in form with the species and genera in proportion to other changes, 


\section{The Wallace-Darwin Correspondence}

and always constant in each species yet confined to the males, and so small and mixed up with the other scales as to produce no effect on the colour or marking of the wings. How could sexual selection produce them?

Your correspondent Mr. Geach is now in England, and if you would like to see him I am sure he would be glad to meet you. He is staying with his brother (address Guildford), but often comes to town.

Hoping that you have quite recovered from your accident and that the great work is progressing, believe me, dear Darwin, yours very faithfully, ALFRED R. WALLACE.

P.S.-You will perhaps be pleased to hear that German, French, and Danish translations of my "Malay Archipelago" are in progress.-A. R. W.

Caerleon, Barmouth, N. Wales. June 25, 1869.

My dear Wallace,-We have been here a fortnight, and shall remain here till the beginning of August. I can say nothing good about my health, and I am so weak that I can hardly crawl half a mile from the house; but I hope I may improve, and anyhow the magnificent view of Cader is enjoyable.

I do not know that I have anything to ask Mr. Geach, nor do I suppose I shall be in London till late in the autumn, but I should be particularly obliged, if you have any communication with $\mathrm{Mr}$. Geach, if you would express for me my sincere thanks for his kindness in sending me the very valuable answers on Expression. I wrote some months ago to him in answer to his last letter.

I would ask him to Down, but the fatigue to me of receiving a stranger is something which to you would be utterly unintelligible.

I think I have heard of the scales on butterflies; but 245 


\section{Alfred Russel Wallace}

there are lots of sexual characters which quite baffle all powers of even conjecture.

You are quite correct, that I felt forced to make all additions to the "Origin" as short as possible.

I am indeed pleased to hear, and fully expected, that your Malay work would be known throughout Europe.

Oh dear! what would I not give for a little more strength to get on with my work.-Ever yours,

C. Darwin.

I wish that you could have told me that your place in the new Museum was all settled.

9 St. Mark's Crescent, N.W. October 20, 1869.

Dear Darwin,-I do not know your son's (Mr. George Darwin's) address at Cambridge. Will you be so good as to forward him the enclosed note begging for a little information?

I was delighted to see the notice in the Academy that you are really going to bring out your book on Man. I anticipate for it an enormous sale, and shall read it with intense interest, although $I$ expect to find in it more to differ from than in any of your other books. Some reason. able and reasoning opponents are now taking the field. I have been writing a little notice of Murphy's " Habit and Intelligence," which, with much that is strange and unintelligible, contains some very acute criticisms and the statement of a few real difficulties. Another article just sent me from the Month contains some good criticism. How incipient organs can be useful is a real difficulty, so is the independent origin of similar complex organs; but most of his other points, though well put, are not very formidable. I am trying to begin a little book on the Distribution of Animals, but I fear I shall not make much of it from my idleness in collecting facts. 


\section{The Wallace-Darwin Correspondence}

I shall make it a popular sketch first, and, if it succeeds, gather materials for enlarging it at a future time. If any suggestion occurs to you as to the kind of maps that would be best, or on any other essential point, I should be glad of a hint. I hope your residence in Wales did you good. I had no idea you were so near Dolgelly till I met your son there one evening when $I$ was going to leave the next morning. It is a glorious country, but the time I like is May and June-the foliage is so glorious.

Sincerely hoping you are pretty well, and with kind regards to Mrs. Darwin and the rest of your family, believe me yours very faithfully, ALFRED R. WALLACE.

Down, Beckenham, Kent, S.E. October 21, 1869.

My dear Wallace,-I forwarded your letter at once to my son George, but I am nearly sure that he will not be able to tell you anything; I wish he could for my own sake; but I suspect there are few men in England who could. Pray send me a copy or tell me where your article on Murphy will be published. I have just received the Month, but have only read half as yet. I wish I knew who was the author; you ought to know, as he admires you so much; he has a wonderful deal of knowledge, but his difficulties have not troubled me much as yet, except the case of the dipterous larva. My book will not be published for a long time, but Murray wished to insert some notice of it. Sexual selection has been a tremendous job. Fate has ordained that almost every point on which we differ should be crowded into this vol. Have you seen the October number of the Revue des deux Mondes? It has an article on you, but I have not yet read it; and another article, not yet read, by a very good man on the Transformist School.

I am very glad to hear that you are beginning a book, 247 


\section{Alfred Russel Wallace}

but do not let it be "little," on Distribution, etc. I have no hints to give about maps; the subject would require long and anxious consideration. Before Forbes published his essay on Distribution and the Glacial Period I wrote out and had copied an essay on the same subject, which Hooker read. If this MS. would be of any use to you, on account of the references in it to papers, etc., I should be very glad to lend it, to be used in any way; for I foresee that my strength will never last out to come to this subject.

I have been pretty well since my return from Wales, though at the time it did me no good.

We shall be in London next month, when I shall hope to see you.-My dear Wallace, yours very sincerely,

Ch. Darwin.

9 St. Mark's Crescent, N.W. December 4, [1869].

Dear Darwin,-Dr. Adolf Bernhard Meyer, who translated my book into German, has written to me for permission to translate my original paper in the Linnean Proceedings with yours, and wants to put my photograph and yours in it. If you have given him permission to translate the papers (which I suppose he can do without permission if he pleases), I write to ask which of your photographs you would wish to represent you in Germany - the last, or the previous one by Ernest Edwards, which I think much the best-as if you like I will undertake to order them and save you any more trouble about it. It is, of course, out of the question our meeting to be photographed together, as Mr. Meyer coolly proposes.

Hoping you are well, believe me yours very faithfully,

Alfred R. Wallace.

P.S.-I have written a paper on Geological Time, which will appear in Nature, and I think I have hit upon a solution of your greatest difficulties in that matter.-A. R. W. 


\section{The Wallace-Darwin Correspondence}

Down, Beckenham, Kent, S.E. December 5, 1869.

My dear Wallace,-I wrote to Dr. Meyer that the photographs in England would cost much and that they did not seem to me worth the cost to him, but that I of course had no sort of objection. I should be greatly obliged if you would kindly take the trouble to order any one which you think best: possibly it would be best to wait, unless you feel sure, till you hear again from Dr. M. I sent him a copy of our joint paper. He has kindly sent me the trans. lation of your book, which is splendidly got up, and which I thought I could not better use than by sending it to Fritz Müller in Brazil, who will appreciate it.

I liked your reviews on Mr. Murphy very much; they are capitally written, like everything which is turned out of your workshop. I was specially glad about the eye. If you agree with me, take some opportunity of bringing forward the case of perfected greyhound or racehorse, in proof of the possibility of the selection of many correlated variations. I have remarks on this head in my last book.

If you throw light on the want of geological time, may honour, eternal glory and blessings crowd thick on your head.-Yours most sincerely,

Ch. Darwin.

I forgot to say that I wrote to Dr. M. to say that I should not soon be in London, and that, of all things in the world, I hate most the bother of sitting for photographs, so I declined with many apologies. I have recently refused several applications.

9 St. Mark's Crescent, N.W. January 22, 1870.

Dear Darwin,-My paper on Geological Time having been in type nearly two months, and not knowing when it will appear, I have asked for a proof to send you, Hux. ley and Lyell. The latter part only contains what I think 


\section{Alfred Russel Wallace}

is new, and $I$ shall be anxious to hear if it at all helps to get over your difficulties.

I have been lately revising and adding to my various papers bearing on the "Origin of Species," etc., and am going to print them in a volume immediately, under the title of "Contributions to the Theory of Natural Selection : A Series of Essays."

In the last, I put forth my heterodox opinions as to Man, and even venture to attack the Huxleyan philosophy!

Hoping you are quite well and are getting on with your Man book, believe me, dear Darwin, yours very faithfully,

ALFRed R. WALlact.

P.S.-When you have read the proof and done with it, may I beg you to return it to me ?-A. R. W.

Down, Beckenham, Kent, S.E. January 26, [1870].

My dear Wallace,-I have been very much struck by your whole article (returned by this post), especially as to rate of denudation, for the still glaciated surfaces have of late most perplexed me. Also especially on the lesser mutations of climate during the last 60,000 years; for I quite think with you no cause so powerful in inducing specific changes, through the consequent migrations. Your argument would be somewhat strengthened about organic changes having been formerly more rapid, if Sir W. Thomson is correct that physical changes were formerly more violent and abrupt.

The whole subject is so new and vast that $I$ suppose you hardly expect anyone to be at once convinced, but that he should keep your view before his mind and let it ferment. This, I think, everyone will be forced to do. I have not as yet been able to digest the fundamental notion 250 


\section{The Wallace-Darwin Correspondence}

of the shortened age of the sun and earth. Your whole paper seems to me admirably clear and well put. I may remark that Rütimeyer has shown that several wild mam. mals in Switzerland since the neolithic period have had their dentition and, I think, general size slightly modified. I cannot believe that the Isthmus of Panama has been open since the commencement of the glacial period ; for, notwithstanding the fishes, so few shells, crustaceans, and, according to Agassiz, not one echinoderm is common to the sides. I am very glad you are going to publish all your papers on Natural Selection: I am sure you are right, and that they will do our cause much good.

But I groan over Man-you write like a metamorphosed (in retrograde direction) naturalist, and you the author of the best paper that ever appeared in the Anthropological Review! Eheu! Eheu! Eheu!-Your miserable friend,

C. Darwin.

Down, Beckenham, Kent. March 31, 1870.

My dear Wallace,-Many thanks for the woodcut, which, judging from the rate at which I crawl on, will hardly be wanted till this time next year. Whether I shall have it reduced, or beg Mr. Macmillan for a stereotype, as you said I might, I have not yet decided.

I heartily congratulate you on your removal being over, and I much more heartily condole with myself at your having left London, for I shall thus miss my talks with you which I always greatly enjoy.

I was excessively pleased at your review of Galton, and $I$ agree to every word of it. I must add that I have just re-read your article in the Anthropological Review, and $I$ defy you to upset your own doctrine.-Ever yours very sincerely,

Ch. Darwin. 


\section{Alfred Russel Wallace}

Down, Beckenham, Kent. April 20, [1870].

My dear Wallace,-I have just received your book ["Natural Selection"]" and read the preface. There never has been passed on me, or indeed on anyone, a higher eulogium than yours. I wish that I fully deserved it. Your modesty and candour are very far from new to me. I hope it is a satisfaction to you to reflect-and very few things in my life have been more satisfactory to methat we have never felt any jealousy towards each other, though in one sense rivals. I believe that I can say this of myself with truth, and I am absolutely sure that it is true of you.

You have been a good Christian to give a list of your additions, for I want much to read them, and I should hardly have had time just at present to have gone through all your articles.

Of course, I shall immediately read those that are new or greatly altered, and I will endearour to be as honest as can reasonably be expected. Your book looks remarkably. well got up.-Believe me, my dear Wallace, to remain yours very cordially,

CH. DarWIN.

Down, Beckenham, Kent, S.E. June 5, 1870. ।

My dear Wallace,-As imitation and protection are your subjects I have thought that you would like to possess the enclosed curious drawing. The note tells all I know about it.-Yours very sincerely,

Ch. Darwin.

P.S. - I read not long ago a German article on the colours of female birds, and that author leaned rather strongly to your side about nidification. I forget who the author was, but he seemed to know a good deal.-C. D.

1 Inserted by A. R. W. 


\section{The Wallace-Darwin Correspondence}

Holly House, Barking, E. July 6, 1870.

Dear Darwin,-Many thanks for the drawing. I must say, however, the resemblance to a snake is not very striking, unless to a cobra not found in America. It is also evident that it is not Mr. Bates's caterpillar, as that threw the head backwards so as to show the feet above, forming imitations of keeled scales.

Claparède has sent me his critique on my book. You will probably have it too. His arguments in reply to my heresy seem to me of the weakest. I hear you have gone to press, and I look forward with fear and trembling to being crushed under a mountain of facts!

I hear you were in town the other day. When you are again, I should be glad to come at any convenient hour and give you a call.

Hoping your health is improving, and with kind remem. brances to Mrs. Darwin and all your family, believe me yours very faithfully,

Alfred R. WaLlaCt.

In "My Life" (Vol. II., p. 7) Wallace wrote: "In the year $1870 \mathrm{Mr}$. A. W. Bennett read a paper before Section $\mathrm{D}$ of the British Association at Liverpool entitled 'The Theory of Natural Selection from a Mathematical Point of View, and this paper was printed in full in Nature of November 10, 1870. To this I replied on November 17, and my reply so pleased Mr. Darwin that he at once wrote to me as follows :"

Down, Beckenham, Kent, S.E. November 22, 1870.

My dear Wallace,-I must ease myself by writing a few words to say how much $I$ and all others in this house admire your article in Nature. You are certainly an unparalleled master in lucidly stating a case and in arguing. Nothing ever was better done than your argument about the term 253 


\section{Alfred Russel Wallace}

"origin of species," and the consequences about much being gained, even if we know nothing about precise cause of each variation. By chance I have given a few words in my first volume, now some time printed off, about mimetic butterflies, and have touched on two of your points, viz. on species already widely dissimilar not being made to resemble each other, and about the variations in Lepidoptera being often well pronounced. How strange it is that Mr. Bennett or anyone else should bring in the action of the mind as a leading cause of variation, seeing the beautiful and complex adaptations and modifications of structure in plants, which I do not suppose they would say had minds.

I have finished the first volume, and am half-way through the first proof of the second volume, of my confounded book, which half kills me by fatigue, and which I much fear will quite kill me in your good estimation.

If you have leisure I should much like a little news of you and your doings and your family.-Ever yours very sincerely,

Ch. Dartin.

Holly House, Barking, E. November 24, 1870.

Dear Darwin,-Your letter gave me very great pleasure. We still agree, I am sure, on nineteen points out of twenty, and on the twentieth $I$ am not inconvincible. But then I must be convinced by facts and arguments, not by highhanded ridicule such as Claparède's.

I hope you see the difference between such criticisms as his, and that in the last number of the North American Review, where my last chapter is really criticised, point by point; and though I think some of it very weak, I admit that some is very strong, and almost converts me from the error of my ways.

As to your new book, I am sure it will not make me think less highly of you than $I$ do, unless you do, what 


\section{The Wallace-Darwin Correspondence}

you have never done yet, ignore facts and arguments that go against you.

I am doing nothing just now but writing articles and putting down anti-Darwinians, being dreadfully ridden upon by a horrid old-man-of-the-sea, who has agreed to let me have the piece of land I have set my heart on, and which $I$ have been trying to get of him since last February, but who will not answer letters, will not sign an agreement, and keeps me week after week in anxiety, though I have accepted his own terms unconditionally, one of which is that I pay rent from last Michaelmas! And now the finest weather for planting is going by. It is a bit of a wilderness that can be made into a splendid imitation of a Welsh valley in little, and will enable me to gather round me all the beauties of the temperate flora which I so much admire, or I would not put up with the little fellow's ways. The fixing on a residence for the rest of your life is an important event, and I am not likely to be in a very settled frame of mind for some time.

I am answering A. Murray's Geographical Distribution of Coleoptera for my Entomological Society Presidential Address, and am printing a second edition of my "Essays," with a few notes and additions. Very glad to see (by your writing yourself) that you are better, and with kind regards to all your family, believe me, dear Darwin, yours very faithfully,

Alfred R. Wallace.

Holly House, Barking, E. January 27, 1871.

Dear Darwin,--Many thanks for your first volume, ${ }^{1}$ which I have just finished reading through with the greatest pleasure and interest, and $I$ have also to thank you for the great tenderness with which you have treated me and my heresies.

1 " The Descent of Man."

255 


\section{Alfred Russel Wallace}

On the subject of sexual selection and protection you do not yet convince me that $I$ am wrong, but I expect your heaviest artillery will be brought up in your second volume, and I may have to capitulate. You seem, however, to have somewhat misunderstood my exact meaning, and I do not think the difference between us is quite so great as you seem to think it. There are a number of passages in which you argue against the view that the female has, in any large number of cases, been "specially modified " for protection, or that colour has generally been obtained by either sex for purposes of protection.

But my view is, and I thought I had made it clear, that the female has (in most cases) been simply prevented from acquiring the gay tints of the male (even when there was a tendency for her to inherit it) because it was hurtful; and, that when protection is not needed, gay colours are so generally acquired by both sexes as to show that inheritance by both sexes of colour variations is the most usual, when not prevented from acting by Natural Selection.

The colour itself may be acquired either by sexual selection or by other unknown causes. There are, however, difficulties in the very wide application you give to sexual selection which at present stagger me, though no one was or is more ready than myself to admit the perfect truth of the principle or the immense importance and great variety of its applications. Your chapters on Man are of intense interest, but as touching my special heresy not as yet altogether convincing, though of course I fully agree with every word and every argument which goes to prove the "evolution" or "development" of man out of a lower form. My only difficulties are as to whether you have accounted for every step of the development by ascertained laws. Feeling sure that the book will keep up and 


\section{The Wallace-Darwin Correspondence}

increase your high reputation and be immensely successful, as it deserves to be, believe me, dear Darwin, yours very faithfully,

ALFRed R. WALlaCe.

Down, Beckenham, Kent, S.E. January 30, 1871.

My dear Wallace,-Your note has given me very great pleasure, chiefly because I was so anxious not to treat you with the least disrespect, and it is so difficult to speak fairly when differing from anyone. If I had offended you, it would have grieved me more than you will readily believe. Secondly, I am greatly pleased to hear that Vol. I. interests you; I have got so sick of the whole subject that I felt in utter doubt about the value of any part. I intended when speaking of the female not having been specially modified for protection to include the prevention of characters acquired by the $\hat{\sigma}$ being transmitted to the of; but I now see it would have been better to have said "specially acted on," or some such term. Possibly my intention may be clearer in Vol. II. Let me say that my conclusions are chiefly founded on a consideration of all animals taken in a body, bearing in mind how common the rules of sexual differences appear to be in all classes. The first copy of the chapter on Lepidoptera agreed pretty closely with you. I then worked on, came back to Lepidoptera, and thought myself compelled to alter it, finished sexual selection, and for the last time went over Lepidoptera, and again I felt forced to alter it.

I hope to God there will be nothing disagreeable to you in Vol. II., and that I have spoken fairly of your views. I feel the more fearful on this head, because I have just read (but not with sufficient care) Mivart's book, ${ }^{1}$ and I feel absolutely certain that he meant to be fair (but he was stimulated by theological fervour); yet $I$ do not think he 1 “The Genesis of Species," by St. G. Mivart. 1871.

$\mathbf{R}$ 


\section{Alfred Russel Wallace}

has been quite fair : he gives in one place only half of one of my sentences, ignores in many places all that $I$ have said on effects of use, speaks of my dogmatic assertion, " of false belief," whereas the end of paragraph seems to me to render the sentence by no means dogmatic or arrogant; etc. etc. I have since its publication received some quite charming letters from him.

What an ardent (and most justly) admirer he is of you. His work, I do not doubt, will have a most potent influence versus Natural Selection. The pendulum will now swing against us. The part which, I think, will have most influence is when he gives whole series of cases, like that of whalebone, in which we cannot explain the gradational steps; but such cases have no weight on my mind-if a few fish were extinct, who on earth would have ventured even to conjecture that lung had originated in swimbladder? In such a case as Thylacines, I think he was bound to say that the resemblance of the jaw to that of the $\operatorname{dog}$ is superficial; the number and correspondence and development of teeth being widely different. I think, again, when speaking of the necessity of altering a number of characters together, he ought to have thought of man having power by selection to modify simultaneously or almost simultaneously many points, as in making a greyhound or racehorse-as enlarged upon in my "Domestic Animals."

Mivart is savage or contemptuous about my "moral sense," and so probably will you be. I am extremely pleased that he agrees with my position, as far as animal nature is concerned, of man in the series; or, if anything, thinks I have erred in making him too distinct.

Forgive me for scribbling at such length.

You have put me quite in good spirits, I did so dread having been unintentionally unfair towards your views. I 258 


\section{The Wallace-Darwin Correspondence}

hope earnestly the second volume will escape as well. I care now very little what others say. As for our not quite agreeing, really in such complex subjects it is almost impossible for two men who arrive independently at their conclusions to agree fully-it would be unnatural for them to do so.-Yours ever very sincerely,

Ch. Darwin.

Holly House, Barking, E. March 11, 1871.

Dear Darwin,-I need not say that I read your second volume with, if possible, a greater interest than the first, as so many topics of special interest to me are treated of. You will not be surprised to find that you have not convinced me on the "female protection" question, but you will be surprised to hear that I do not despair of convincing you. I have been writing, as you are aware, a review for the Academy, which I tried to refuse doing, but the Editor used as an argument the statement that you wished me to do so. It is not an easy job fairly to summarise such a book, but I hope I have succeeded tolerably. When I got to discussion, I felt more at home, but I most sincerely trust that I may not have let pass any word that may seem to you in the least too strong.

You have not written a word about me that I could wish altered, but as I know you wish me to be candid with you, I will mention that you have quoted one passage in a note (p. 376, Vol. II.) which seems to me a caricature of anything I have written.

Now let me ask you to rejoice with me, for I have got my chalk pit, and am hard at work engineering a road up its precipitous slopes. I hope you may be able to come and see me there some day, as it is an easy ride from London, and I shall be anxious to know if it is equal to the pit in the wilds of Kent Mrs. Darwin mentioned when I lunched with you. Should your gardener in the autumn have any 


\section{Alfred Russel Wallace}

thinnings out of almost any kind of hardy plants they would be welcome, as I have near four acres of ground in which I want to substitute ornamental plants for weeds.

With best wishes, and hoping you may have health and strength to go on with your great work, believe me, dear Darwin, yours very faithfully,

ALFRED R. WALLACE.

My review will appear next Wednesday.

Down, Beckenham, Kent, S.E. March 16, 1871.

My dear Wallace,-I have just read your grand review. ${ }^{1}$ It is in every way as kindly expressed towards myself as it is excellent in matter. The Lyells have been here, and Sir C. remarked that no one wrote such good scientific reviews as you, and, as Miss Buckley added, you delight in picking out all that is good, though very far from blind to the bad. In all this I most entirely agree. I shall always consider your review as a great honour, and however much my book may hereafter be abused, as no doubt it will be, your review will console me, notwithstanding that we differ so greatly.

I will keep your objections to my views in my mind, but I fear that the latter are almost stereotyped in my mind. I thought for long weeks about the inheritance and selection difficulty, and covered quires of paper with notes, in trying to get out of it, but could not, though clearly seeing that it would be a great relief if I could. I will confine myself to two or three remarks. I have been much impressed with what you urge against colour ${ }^{2}$ in the case

1 In the Academy, March 15, 1871.

2 " Mr. Wallace says that the pairing of butterflies is probably determined by the fact that one male is stronger-winged or more pertinacious than the rest, rather than by the choice of the females. He quotes the case of caterpillars which are brightly coloured and yet sexless. Mr. Wallace also makes the good criticism that 'The Descent of Man' consists of two books mixed together." "Life and Letters of Charles Darwin," iii. 137. 


\section{The Wallace-Darwin Correspondence}

of insects having been acquired through sexual selection. I always saw that the evidence was very weak; but I still think, if it be admitted that the musical instruments of insects have been gained through sexual selection, that there is not the least improbability in colour having been thus gained. Your argument with respect to the denudation of mankind, and also to insects, that taste on the part of one sex would have to remain nearly the same during many generations, in order that sexual selection should produce any effect, I agree to, and I think this argument would be sound if used by one who denied that, for instance, the plumes of birds of paradise had been so gained.

I believe that you admit this, and if so I do not see how your argument applies in other cases. I have recognised for some short time that $I$ have made a great omission in not having discussed, as far as I could, the acquisition of taste, its inherited nature, and its permanence within pretty close limits for long periods.

One other point and I have done: I see by p. 179 of your review that I must have expressed myself very badly to have led you to think that I consider the prehensile organs of males as affording evidence of the females exerting a choice. I have never thought so, and if you chance to remember the passage (but do not hunt for it), pray point it out to me.

I am extremely sorry that I gave the note from $\mathrm{Mr}$. Stebbing; I thought myself bound to notice his suggestion of beauty as a cause of denudation, and thus I was led on to give his argument. I altered the final passage which seemed to me offensive, and I had misgivings about the first part.

I heartily wish I had yielded to these misgivings. I will omit in any future edition the latter half of the note. 


\section{Alfred Russel Wallace}

.I have heard from Miss Buckley that you have got possession of four chalk pit, and I congratulate you on the tedious delay being over. I fear all our bushes are so large that there is nothing which we are at all likely to grub up.

Years ago we threw away loads of things. I should very much like to see your house and grounds; but I fear the journey would be too long. Going even to Kew knocks me up, and $I$ have almost ceased trying to do so.

Once again let me thank you warmly for your admirable review.-My dear Wallace, yours ever very sincerely,

C. Darwin.

What an excellent address you gave about Madeira, but I wish you had alluded to Lyell's discussion on land shells, etc.-not that he has said a word on the subject. The whole address quite delighted me. I hear Mr. Crotch ${ }^{1}$ disputed some of your facts about the wingless insects, but he is a crotchety man. As far as I remember, I did not venture to ask Mr. Appleton to get you to review me, but only said, in answer to an inquiry, that you would undoubtedly be the best, or one of the very few men who could do so effectively.

Down, Beckenham, Kent, S.E. March 24, 1871.

My dear Wallace,-Very many thanks for the new edition of your Essays. Honour and glory to you for giving list of additions. It is grand as showing that our subject flourishes, your book coming to a new edition so soon. My book also sells immensely; the edition will, I believe, be 6,500 copies. I am tired with writing, for the load of letters which I receive is enough to make a man cry, yet some few are curious

1 G. Crotch was a well-known coleopterist and offlcial in the University Library at Cambridge. 


\section{The Wallace-Darwin Correspondence}

and valuable. I got one to-day from a doctor on the hair on backs of young weakly children, which afterwards falls off. Also on hairy idiots. But I am tired to death, so farewell.

Thanks for your last letter.

There is a very striking second article on my book in the Pall Mall. The articles in the Spectator ${ }^{1}$ have also interested me much.-Again farewell.

C. DARWIN.

Holly House, Barking, E. May 14, 1871.

Dear Darwin,-Have you read that very remarkable book "The Fuel of the Sun" ? If not, get it. It solves the great problem of the almost unlimited duration of the sun's heat in what appears to me a most satisfactory manner. I recommended it to Sir C. Lyell, and he tells me that Grove spoke very highly of it to him. It has been somewhat ignored by the critics because it is by a new man with a perfectly original hypothesis, founded on a vast accumulation of physical and chemical facts; but not being encumbered with any mathematical shibboleths, they have evidently been afraid that anything so intelligible could not be sound. The manner in which everything in physical astronomy is explained is almost as marvellous as the powers of Natural Selection in the same way, and naturally excites a suspicion that the respective authors are pushing their theories "a little too far."

If you read it, get Proctor's book on the Sun at the same time, and refer to his coloured plates of the protuberances, corona, etc., which marvellously correspond

1 Spectator, March 11 and 18, 1871. "With regard to the evolution of conscience the reviewer thinks that $\mathrm{Mr}$. Darwin comes much nearer to the 'kernel of the psychological problem' than many of his predecessors. The second article contains a good discussion of the bearing of the book on the question of design, and concludes by finding in it a vindication of Theism more wonderful than that in Paley's ' Natural Theology." "-_ "Life and Letters," lii. 138. 


\section{Alfred Russel Wallace}

with what Matthieu Williams's theory requires. The author is a practical chemist engaged in iron manufacture, and it is from furnace chemistry that he has been led to the subject. I think it the most original, most thoughtful and most carefully-worked-out theory that has appeared for a long time, and it does not say much for the critics that, as far as I know, its great merits have not been properly recognised.

I have been so fully occupied with road-making, welldigging, garden- and house-planning, planting, etc., that I have given up all other work.

Do you not admire our friend Miss Buckley's admirable article in Macmillan? It seems to me the best and most original that has been written on your book.

Hoping you are well, and are not working too hard, I remain yours very faithfully,

Alfred R. Wallace.

Down, Beckenham, Kent. July 9, 1871.

My dear Wallace,-I send by this post a review by Chauncey Wright, as I much want your opinion of it, as soon as you can send it. I consider you an incomparably better critic than I am. The article, though not very clearly written, and poor in parts for want of knowledge, seems to me admirable.

Mivart's book is producing a great effect against Natural Selection, and more especially against me. Therefore, if you think the article even somewhat good, I will write and get permission to publish it as a shilling pamphlet, together with the MS. addition (enclosed), for which there was not room at the end of the review. I do not suppose I should lose more than $£ 20$ or $£ 30$.

I am now at work at a new and cheap edition of the " Origin," and shall answer several points in Mivart's book and introduce a new chapter for this purpose; but I treat 


\section{The Wallace-Darwin Correspondence}

the subject so much more concretely, and I daresay less philosophically, than Wright, that we shall not interfere with each other. You will think me a bigot when I say, after studying Mivart, I was never before in my life so convinced of the general (i.e. not in detail) truth of the views in the "Origin." I grieve to see the omission of the words by Mivart, detected by Wright." I complained to $M$. that in two caspe ha rotes only the commencement of sentences by me and thus modifies my meaning; but I never supposed he would have omitted words. There are other cases of what I consider unfair treatment. I conclude with sorrow that though he means to be honourable, he is so bigoted that he cannot act fairly.

I was glad to see your letter in Nature, though I think you were a little hard on the silly and presumptuous man.

I hope that your house and grounds are progressing well, and that you are in all ways flourishing.

I have been rather seedy, but a few days in London did me much good; and my dear good wife is going to take me somewhere, nolens volens, at the end of this month.

C. DARWin.

Holly House, Barking, E. July 12, 1871.

Dear Darwin,-Many thanks for giving me the opportunity to read at my leisure the very talented article of Mr. C. Wright. His criticism of Mivart, though very severe, is, I think, in most cases sound; but I find the larger part of the article so heavy and much of the language and argument so very obscure, that I very much doubt the utility of printing it separately. I do not think the readers of Mivart could

1 North American Review, Vol. 113, pp. 83, 84. Chauncey Wright points out that the words omitted are "essential to the point on which he [Mr. Mivart] cites Mr. Darwin's authority." It should be mentioned that the passage from which words are omitted is not given within inverted commas by Mr. Mivart.See "Life and Letters of Charles Darwin," iii. 144. 


\section{Alfred Russel Wallace}

ever read it in that form, and $I$ am sure your own answer to Mivart's arguments will be so much more clear and to the point, that the other will be unnecessary. You might extract certain portions in your own chapter, such as the very ingenious suggestion as to the possible origin of mammary glands, as well as the possible use of the rattle of the rattlesnake, etc.

I cannot see the force of Mivart's objection to the theory of production of the long neck of the giraffe (suggested in my first Essay), and which C. Wright seems to admit, while his "watch-tower" theory seems to me more difficult and unlikely as a means of origin. The argument, "Why haven't other allied animals been modified in the same way?" seems to me the weakest of the weak. I must say also I do not see any great reason to complain of the "words" left out by Mivart, as they do not seem to me materially to affect the meaning. Your expression, " and tends to depart in a slight degree," I think hardly grammatical ; a tendency to depart cannot very well be said to be in a slight degree; a departure can, but a tendency must be either a slight tendency or a strong tendency; the degree to which the departure may reach must depend on favourable or unfavourable causes in addition to the tendency itself. Mivart's words, "and tending to depart from the parental type," seem to me quite unobjectionable as a paraphrase of yours, because the "tending" is kept in; and your own view undoubtedly is that the tendency may lead to an ultimate departure to any extent. Mivart's error is to suppose that your words favour the view of sudden departures, and I do not see that the expression he uses really favours his view a bit more than if he had quoted your exact words. The expression of yours he relies upon is evidently " the whole organism seeming to have become plastic," and he argues, no doubt erroneously, that having so become "plastic," any amount or 


\section{The Wallace-Darwin Correspondence}

a larger amount of sudden variation in some direction is likely.

Mivart's greatest error, the confounding "individual variations" with "minute or imperceptible variations," is well exposed by $C$. Wright, and that part I should like to see reprinted; but $I$ always thought you laid too much stress on the slowness of the action of Natural Selection owing to the smallness and rarity of favourable variations. In your chapter on Natural Selection the expressions, "extremely slight modifications," "every variation even the slightest," " every grade of constitutional difference," occur, and these have led to errors such as Mivart's. I say all this because I feel sure that Mivart would be the last to intentionally misrepresent you, and he has told me that he was sorry the word " infinitesimal," as applied to variations used by Natural Selection, got into his book, and that he would alter it, as no doubt he has done, in his second edition.

Some of Mivart's strongest points-the eye and ear, for instance-are unnoticed in the review. You will, of course, reply to these. His statement of the "missing link" argument is also forcible, and has, I have no doubt, much weight with the public. As to all his minor arguments, I feel with you that they leave Natural Selection stronger than ever, while the two or three main arguments do leave a lingering doubt in my mind of some fundamental organic law of development of which we have as yet no notion.

Pray do not attach any weight to my opinions as to the review. It is very clever, but the writer seems a little like those critics who know an author's or an artist's meaning better than they do themselves.

My house is now in the hands of a contractor, but I am wall-building, etc., and very busy.-With best wishes, believe me, dear Darwin, yours very faithfully,

Alfred R. Wallace. 


\section{Alfred Russel Wallace}

Down, Beckenham, Kent. July 12, 1871.

My dear Wallace,-Very many thanks. As soon as I read your letter I determined not to print the paper, notwithstanding my eldest daughter, who is a very good critic, thought it so interesting as to be worth reprinting. Then my wife came in, and said, "I do not much care about these things and shall therefore be a good judge whether it is very dull." So I will leave my decision open for a day or two. Your letter has been, and will be, of use to me in other ways : thus I had quite forgotten that you had taken up the case of the giraffe in your first memoir, and I must look to this. I feel very doubtful how far I shall succeed in answering Mivart; it is so difficult to answer objections to doubtful points and make the discussion readable. I shall make only a selection. The worst of it is that I cannot possibly hunt through all my references for isolated points; it would take me three weeks of intolerably hard work. I wish I had your power of arguing clearly. At present I feel sick of everything, and if I could occupy my time and forget my daily discomforts or little miseries, I would never publish another word. But I shall cheer up, I daresay, soon, being only just got over a bad attack. Farewell. God knows why I bother you about myself.

I can say nothing more about missing links than what I have said. I should rely much on pre-Silurian times; but then comes Sir W. Thomson like an odious spectre. Farewell.-Yours most sincerely,

Ch. Darwin.

I was grieved to see in the Daily News that the madman about the flat earth has been threatening your life. What an odious trouble this must have been to you, 


\section{The Wallace-Darwin Correspondence}

P.S.-There is a most cutting review of me in the Quarterly: ${ }^{1}$ I have only read a few pages. The skill and style make me think of Mivart. I shall soon be viewed as the most despicable of men. This Quarterly review tempts me to republish Ch. Wright, even if not read by anyone, just to show that someone will say a word against Mivart, and that his (i.e. Mivart's) remarks ought not to be swallowed without some reflection.

I quite agree with what you say that Mivart fully intends to be honourable; but he seems to me to have the mind of a most able lawyer retained to plead against us, and especially against me. God knows whether my strength and spirit will last out to write a chapter versus Mivart and others; I do so hate controversy, and feel I should do it so badly.

P.S.-I have now finished the review : there can be no doubt it is by Mivart, and wonderfully clever.

Holly House, Barking, E. July 16, 1871.

Dear Darwin,-I am very sorry you are so unwell, and that you allow criticisms to worry you so. Remember the noble army of converts you have made! and the host of the most talented men living who support you wholly. What do you think of putting C. Wright's article as an appendix to the new edition of the "Origin"? That would get it read, and obviate my chief objection, that the people who read Mivart and the "Origin" will very few of them buy a separate pamphlet to read. Pamphlets are such nuisances. I don't think Mivart could have written the Quarterly article, but I will look at it and shall, I think, be able to tell. Pray keep your spirits up. I am so distracted by building troubles that I can write nothing,

$$
1 \text { July, } 1871 .
$$




\section{Alfred Russel Wallace}

and I shall not, till I gęt settled in my new house, some time next spring, I hope.-With best wishes, believe me yours very faithfully,

AlFred R. Wallace.

Haredene, Albury, Guildford. August 1, 1871.

My dear Wallace,-Your kind and sympathetic letter pleased me greatly and did me good, but as you are so busy I did not answer it. I write now because $I$ have just received a very remarkable letter from Fritz Müller (with butterflies' wings gummed on paper as illustrations) on mimicry, etc. I think it is well worth your reading, but I will not send it, unless I receive a $1 / 2 \mathrm{~d}$. card to this effect. He puts the difficulty of first start in imitation excellently, and gives wonderful proof of closeness of the imitation. He hints a curious addition to the theory in relation to sexual selection, which you will think madly hypothetical : it occurred to me in a very different class of cases, but I was afraid to publish it. It would aid the theory of imitative protection, when the colours are bright. He seems much pleased with your caterpillar theory. I wish the letter could be published, but without coloured illustrations [it] would, I fear, be unintelligible.

I have not yet made up my mind about Wright's review; I shall stop till I hear from him. Your suggestion would make the "Origin," already too large, still more bulky.

By the way, did Mr. Youmans, of the United States, apply to you to write a popular sketch of Natural Selection? I told him you would do it immeasurably better than anyone in the world. My head keeps very rocky and wretched, but I am better.-Ever yours most truly,

C. Dartin. 


\section{The Wallace-Darwin Correspondence}

Holly House, Barking, E. March 3, 1872.

Dear Darwin,-Many thanks for your new edition of the "Origin," which I have been too busy to acknowledge before. I think your answer to Mivart on the initial stages of modification ample and complete, and the comparison of whale and duck most beautiful. I always saw the fallacy of these objections, of course. The eye and ear objection you have not so satisfactorily answered, and to me the difficulty exists of how three times over an organ of sight was developed with the apparatus even approximately identical. Why should not, in one case out of the three, the heat rays or the chemical rays have been utilised for the same purpose, in which case no translucent media would have been required, and yet vision might have been just as perfect? The fact that the eyes of insects and molluses are transparent to us shows that the very same limited portion of the rays of the spectrum is utilised for vision by them as by us.

The chances seem to me immense against that having occurred through "fortuitous variation," as Mivart puts it.

I see still further difficulties on chis point but cannot go into them now. Many thanks for your kind invitation. I will try and call some day, but I am now very busy trying to make my house habitable by Lady Day, when I must be in it.-Believe me yours very faithfully,

Alfred R. Wallach.

Down, Beckenham, Kent. July 27, 1872.

My dear Wallace,-I have just read with infinite satisfaction your crushing article in Nature. ${ }^{1} \mathrm{I}$ have been the more glad to see it, as I have not seen the book itself : I

1 A review of Dr. Bree's book, "An Exposition of Fallacies in the Hypotheses of Mr. Darwin."-Nature, July 25, 1872. 


\section{Alfred Russel Wallace}

did not order it, as I felt sure from Dr. B.'s former book that he could write nothing of value. But assuredly I did not suppose that anyone would have written such a mass of inaccuracies and rubbish. How rich is everything which he says and quotes from Herbert Spencer!

By the way, I suppose that you read H. Spencer's answer to Martineau : it struck me as quite wonderfully good, and I felt even more strongly inclined than before to bow in reverence before him. Nothing has amused me more in your review than Dr. B.'s extraordinary presumption in deciding that such men as Lyell, Owen, H. Spencer, Mivart, Gaudry, etc. etc., are all wrong. I daresay it would be very delightful to feel such overwhelming confidence in oneself.

I have had a poor time of it of late, rarely having an hour of comfort, except when asleep or immersed in work; and then when that is over I feel dead with fatigue. I am now correcting my little book on Expression; but it will not be published till November, when of course a copy will be sent to you. I shall now try whether I can occupy myself without writing anything more on so difficult a subject as Evolution.

I hope you are now comfortably settled in your new house, and have more leisure than you have had for some time. I have looked out in the papers for any notice about the curatorship of the new Museum, but have seen nothing. If anything is decided in your favour, $I$ beg you to inform me.-My dear Wallace, very truly yours, C. DARwIN.

How grandly the public has taken up Hooker's case.

Down. August 3, [1872].

My dear Wallace,-I hate controversy, chiefly perhaps because $I$ do it badly; but as Dr. Bree accuses you of "blundering," I have thought myself bound to send the 


\section{The Wallace-Darwin Correspondence}

enclosed letter ${ }^{1}$ to Nature, that is, if you in the least desire it. In this case please post it. If you do not at all wish it, I should rather prefer not sending it, and in this case please tear it up. And I beg you to do the same, if you intend answering Dr. Bree yourself, as you will do it incomparably better than I should. Also please tear it up if you don't like the letter.-My dear Wallace, yours very sincerely,

Ch. Darwin.

The Dell, Grays, Essex. August 4, 1872.

Dear Darwin,-I have sent your letter to Nature, as I think it will settle that question far better than anything I can say. Many thanks for it. I have not seen Dr. Bree's letter yet, as I get Nature here very irregularly, but as I was very careful to mention none but real errors in Dr. Bree's book, I do not imagine there will be any necessity for my taking any notice of it. It was really entertaining to have such a book to review, the errors and misconceptions were so inexplicable and the self-sufficiency of the man so amazing. Yet there is some excellent writing in the book, and to a half-informed person it has all the appearance of being a most valuable and authoritative work.

I am now reviewing a much more important book and one that, if I mistake not, will really compel you sooner or later to modify some of your views, though it will not

1 "Bree on Darwinism," Nature, Aug. 8, 1872. The letter is as follows : "Permit me to state-though the statement is almost superfluous-that $\mathrm{Mr}$. Wallace, in his review of Dr. Bree's work, gives with perfect correctness what I intended to express, and what I believe was expressed clearly, with respect to the probable position of man in the early part of his pedigree. As I have not seen Dr. Bree's recent work, and as his letter is unintelligible to me, I cannot even conjecture how he has so completely mistaken my meaning; but, perhaps, no one who has read Mr. Wallace's article, or who has read a work formerly published by Dr. Bree on the same subject as his recent one, will be surprised at any amount of misunderstanding on his part.-Charles Darwin, Aug. 3." See "Life and Letters of Charles Darwin," iii. 167. 


\section{Alfred Russel Wallace}

at all affect the main doctrine of Natural Selection as applied to the higher animals. I allude, of course, to Bastian's "Beginnings of Life," which you have no doubt got. It is hard reading, but intensely interesting. I am a thorough convert to his main results, and it seems to me that nothing more important has appeared since your "Origin." It is a pity he is so awfully voluminous and discursive. When you have thoroughly digested it I shall be glad to know what you are disposed to think. My first notice of it will I think appear in Nature next week, but I have been hurried for it, and it is not so well written an article as I could wish.

I sincerely hope your health is improving.-Believe me yours very faithfully,

Alfred R. Wallace.

P.S.-I fear Lubbock's motion is being pushed off to the end of the Session, and Hooker's case will not be fairly considered. I hope the matter will not be allowed to drop.A. R. W.

Down, Beckenham, Kent. August 28, 1872.

My dear Wallace,-I have at last finished the gigantic job of reading Dr. Bastian's book, and have been deeply interested in it. You wished to hear my impression, but it is not worth sending.

He seems to me an extremely able man, as indeed I thought when I read his first essay. His general argument in favour of archebiosis ${ }^{1}$ is wonderfully strong; though I cannot think much of some few of his arguments. The result is that $I$ am bewildered and astonished by his statements, but am not convinced; though on the whole it seems to me probable that archebiosis is true. I am not convinced partly I think owing to the deductive

1 That is to say, spontaneous generation. For the distinction between archebiosis and heterogenesis, see Bastian, Chap. VI. See also "Life and Letters of Charles Darwin," iil. 168. 


\section{The Wallace-Darwin Correspondence}

cast of much of his reasoning; and I know not why, but I never feel convinced by deduction, even in the case of H. Spencer's writings. If Dr. B.'s book had been turned upside down, and he had begun with the various cases of heterogenesis, and then gone on to organic and afterwards to saline solutions, and had then given his general arguments, I should have been, I believe, much more influenced. I suspect, however, that my chief difficulty is the effect of old convictions being stereotyped on my brain. I must have more evidence that germs or the minutest fragments of the lowest forms are always killed by $212^{\circ}$ of Fahr. Perhaps the mere reiteration of the statements given by Dr. B. by other men whose judgment I respect and who have worked long on the lower organisms would suffice to convince me. Here is a fine confession of intellectual weakness; but what an inexplicable frame of mind is that of belief.

As for Rotifers and Tardigrades being spontaneously generated, my mind can no more digest such statements, whether true or false, than my stomach can digest a lump of lead.

Dr. B. is always comparing archebiosis as well as growth to crystallisation; but on this view a Rotifer or Tardigrade is adapted to its humble conditions of life by a happy accident; and this I cannot believe. That observations of the above nature may easily be altogether wrong is well shown by Dr. B. having declared to Huxley that he had watched the entire development of a leaf of Sphagnum. He must have worked with very impure materials in some cases, as plenty of organisms appeared in a saline solution not containing an atom of nitrogen.

I wholly disagree with Dr. B. about many points in his latter chapters. Thus the frequency of generalised forms in the older strata seems to me clearly to indicate the com. mon descent with divergence of more recent forms. 


\section{Alfred Russel Wallace}

Notwithstanding all his sneers, I do not strike my colours as yet about pangenesis. I should like to live to see archebiosis proved true, for it would be a discovery of transcendent importance; or if false I should like to see it disproved, and the facts otherwise explained; but I shall not live to see all this. If ever proved, Dr. B. will have taken a prominent part in the work. How grand is the onward rush of science; it is enough to console us for the many errors which we have committed and for our efforts being overlaid and forgotten in the mass of new facts and new views which are daily turning up.

This is all I have to say about Dr. B.'s book, and it certainly has not been worth saying. Nevertheless, reward me whenever you can by giving me any news about your appointment to the Bethnal Green Museum.-My dear Wallace, yours very sincerely,

Ch. Darwin.

The Dell, Grays, Essex. August 31, 1872.

Dear Darwin,--Many thanks for your long and interest. ing letter about Bastian's book, though I almost regret that my asking you for your opinion should have led you to give yourself so much trouble. I quite understand your frame of mind, and think it quite a natural and proper one. You had hard work to hammer your views into people's heads at first, and if Bastian's theory is true he will have still harder work, because the facts he appeals to are themselves so difficult to establish. Are not you mistaken about the Sphagnum? As I remember it, Huxley detected a fragment of Sphagnum leaf in the same solution in which a fungoid growth had been developed. Bastian mistook the Sphagnum also for a vegetable growth, and on account of this ignorance of the character of Sphagnum, and its presence in the solution, Huxley rejected somewhat contemptuously (and I think very illogically) all Bastian's 276 


\section{The Wallace-Darwin Correspondence}

observations. Again, as to the saline solution without nitrogen, would not the air supply what was required?

I quite agree that the book would have gained force by rearrangement in the way you suggest, but perhaps he thought it necessary to begin with a general argument in order to induce people to examine his new collection of facts. I am impressed most by the agreement of so many observers, some of whom struggle to explain away their own facts. What a wonderfully ingenious and suggestive paper that is by Galton on "Blood Relationship." It helps to render intelligible many of the eccentricities of heredity, atavism, etc.

Sir Charles Lyell was good enough to write to Lord Ripon and Mr. Cole ${ }^{1}$ about me and the Bethnal Green Museum, and the answer he got was that at present no appointment of a director is contemplated. I suppose they see no way of making it a Natural History Museum, and it will have to be kept going by Loan Collections of miscellaneous works of art, in which case, of course, the South Kensington people will manage it. It is a considerable disappointment to me, as I had almost calculated on getting something there.

With best wishes for your good health and happiness, believe me, dear Darwin, yours very faithfully,

AlFRed R. WALLACE.

P.S.-I have just been reading Howorth's paper in the Journal of the Anthropological Institute. How perverse it is. He throughout confounds "fertility" with " increase of population," which seems to me to be the main cause of his errors. His elaborate accumulation of facts in other papers in Nature, on "Subsidence and Elevation of Land," I believe to be equally full of error, and utterly untrustworthy as a whole.-A. R. W.

1 Sir Henry Cole, K.C.B. (1808-80). 


\section{Alfred Russel Wallace}

Down, Beckenham, Kent. September 2, 1872.

My dear Wallace,-I write a line to say that $I$ understood-but I may of course have been mistaken-from Huxley that Bastian distinctly stated that he had watched the development of the scale of Sphagnum : I was astonished, as $I$ knew the appearance of Sphagnum under a high power, and asked a second time; but $I$ repeat that I may have been mistaken. Busk told me that Sharpey had noticed the appearance of numerous Infusoria in one of the solutions not containing any nitrogen; and $I$ do not suppose that any physiologist would admit the possibility of Infusoria absorbing nitrogen gas. Possibly I ought not to have mentioned statements made in private conversation, so please do not repeat them.

I quite agree about the extreme importance of such men as Cohn [illegible] and Carter having observed apparent cases of heterogenesis. At present I should prefer any mad hypothesis, such as that every disintegrated molecule of the lowest forms can reproduce the parent-form, and that the molecules are universally distributed, and that they do not lose their vital power until heated to such a temperature that they decompose like dead organic particles.

I am extremely grieved to hear about the Museum : it is a great misfortune.-Yours most sincerely,

C. Darwin.

I have taken up old botanical work and have given up all theories.

I quite agree about Howorth's paper: he wrote to me and I told him that we differed so widely it was of no use our discussing any point.

As for Galton's paper, I have never yet been able to fully digest it: as far as I have, it has not cleared my 278 


\section{The Wallace-Darwin Correspondence}

ideas, and has only aided in bringing more prominently forward the large proportion of the latent characters.

Down, Beckenham, Kent. October 20, 1872.

My dear Wallace,-I have thought that you would perhaps like to see enclosed specimen and extract from letter (translated from the German by my son) from Dr. W. Marshall, Zoological Assistant to Schlegel at Leyden. Neither the specimen nor extract need be returned; and you need not acknowledge the receipt. The resemblance is not so close, now that the fragments are gummed on card, as I at first thought. Your review of Houzeau was very good: I skimmed through the whole gigantic book, but you managed to pick out the plums much better than I did for myself. You are a born critic. What an admir. able number that was of Nature.

I am writing this at Sevenoaks, where we have taken a house for three weeks and have one more week to stay. We came here that I may get a little rest, of which I stood in much need.-Ever yours very sincerely,

Ch. Darwin.

With respect to what you say about certain instincts of ants having been acquired by experience or sense, have you kept in mind that the neuters have no progeny? I wish I knew whether the fertile females, or queens, do the same work (viz. placing the eggs in warm places, etc.) as the neuters do afterwards; if so the case would be comparatively simple; but I believe this is not the case, and I am driven to selection of varying pre-existing instincts.

\section{The Dell, Grays, Essex. November 15, 1872.}

Dear Darwin,-I should have written earlier to thank you for your book, ${ }^{1}$ but was hoping to be able to read more 1 "Expression of the Emotions." 


\section{Alfred Russel Wallace}

of it before doing so. I have not, however, found time to get beyond the first three chapters, but that is quite sufficient to show me how exceedingly interesting you have made the subject, and how completely and admirably you have worked it out. I expect it will be one of the most popular of your works. I have just been asked to write a review of it for the Quarterly Journal of Science, for which purpose I shall be in duty bound to seek out some deficiencies, however minute, so as to give my notice some flavour of criticism.

The cuts and photos are admirable, and my little boy and girl seized it at once to look at the naughty babies.

With best wishes, believe me yours very faithfully,

AlFred R. Wallace.

P.S.-I will take this opportunity of asking you if you know of any book that will give me a complete catalogue of vertebrate fossils with some indication of their affinities. -A. R. W.

Down, Beckenham, Kent. January 13, 1873.

My dear Wallace,-I have read your review with much interest, and I thank you sincerely for the very kind spirit in which it is written. I cannot say that I am convinced by your criticisms. ${ }^{1}$ If you have ever actually observed a kitten sucking and pounding with extended toes its mother, and then seen the same kitten when a little older doing the same thing on a soft shawl, and ultimately an old cat (as I have seen), and do not admit that it is identically the same action, I am astonished.

1 Quarterly Journal of Science, January, 1873, p. 116 : “ I can hardly believe that when a cat, lying on a shawl or other soft material, pats or pounds it with its feet, or sometimes sucks a piece of it, it is the persistence of the habit of pressing the mammary glands and sucking during klttenhood." Wallace goes on to say that infantine habits are generally completely lost in adult life, and that it seems unlikely that they should persist in a few isolated instances. 


\section{The Wallace-Darwin Correspondence}

With respect to the decapitated frog, ${ }^{1}$ I have always heard of Pflüger as a most trustworthy observer. If, indeed, anyone knows a frog's habits so well as to say that it never rubs off a bit of leaf or other object, which may stick to its thigh, in the same manner as it did the acid, your objection would be valid. Some of Flourens' experiments, in which he removed the cerebral hemisphere from a pigeon, indicate that acts apparently performed consciously can be done without consciousness-I presume through the force of habit; in which case it would appear that intellectual power is not brought into play. Several persons have made such suggestions and objections as yours about the hands being held up in astonishment: ${ }^{2}$ if there was any straining of the muscles, as with protruded arms under fright, I would agree : as it is I must keep to my old opinion, and I daresay you will say that I am an obstinate old blockhead.-My dear Wallace, yours very sincerely,

Ch. Darwin.

The book has sold wonderfully; 9,000 copies have now been printed.

The Dell, Grays, Essex. Wednesday morning, [November, 1873].

Dear Darwin,-Yours just received. Pray act exactly as if nothing had been said to me on the subject. I do not particularly wish for the work, ${ }^{3}$ as, besides being as

1 Wallace speaks of " a readiness to accept the most marvellous conclusions or interpretations of physiologists on what seem very insufficient grounds," and he goes on to assert that the frog experiment is either incorrectly recorded, or else that it " demonstrates volition, and not reflex action."

2 The raising of the hands in surprise is explained (" Expression of the Emotions," 1st Edit., p. 287) on the doctrine of antithesis as being the opposite of listlessness. Mr. Wallace's view (given in the second edition of "Expression of the Emotions," p. 300) is that the gesture is appropriate to sudden defence or to the giving of aid to another person.

3 At this time Darwin, while very busy with other work, had to prepare a second edition of "The Descent of Man," and it is probable that he or the publishers suggested that Wallace should make the necessary corrections.-EDrTor. 


\section{Alfred Russel Wallace}

you say, tedious work, it involves a considerable amount of responsibility. Still, I am prepared to do any literary work of the kind, as I told Bates some time ago, and that is the reason he wrote to me about it. I certainly think, however, that it would be in many ways more satisfactory to you if your son did it, and I therefore hope he may undertake it.

Should he, however, for any reasons, be unable, I am at your service as a dernier ressort.

In case my meaning is not quite clear, I will not do it unless your son has the offer and declines it.-Believe me, dear Darwin, yours very faithfully, ALFRED R. WALLACE.

The Dell, Grays, Essex. November 18, 1873.

Dear Darwin,-I quite understand what you require, and would undertake to do it to the best of my ability. Of course in such work I should not think of offering criticisms of matter.

I do not think I could form any idea of how long it would take by seeing the MSS., as it would all depend upon the amount of revision and working-in required. I have helped Sir C. Lyell with his last three or four editions in a somewhat similar though different way, and for him I have kept an account simply of the hours I was employed in any way for him, and he paid me 5/- an hour; but (of course this is confidential) I do not think this quite enough for the class of work. I should propose for your work $7 /$. an hour as a fair remuneration, and $I$ would put down each day the hours I worked at it.

No doubt you will get it done for very much less by any literary man accustomed to regular literary work and nothing else, and perhaps better done, so do not in the least scruple in saying you decide on employing the gentleman you had in view if you prefer it. 


\section{The Wallace-Darwin Correspondence}

If you send it to me could you let me have all your MSS. copied out, as it adds considerably to the time required if there is any difficulty in deciphering the writing, which in yours (as you are no doubt aware) there often is.

My hasty note to Bates was not intended to be shown you or anyone. I thought he had heard of it from Murray, and that the arrangement was to be made by Murray. -Believe me yours very faithfully,

Alfred R. Wallace.

P.S.-I have been delighted with $\mathrm{H}$. Spencer's "Study of Sociology." Some of the passages in the latter part are grand. You have perhaps seen that I am dipping into politics myself occasionally.-A. R. W.

\section{Down, Beckenham, Kent: November 19, 1873.}

Dear Wallace,-I thank you for your extremely kind letter, and I am sorry that I troubled you with that of yesterday. My wife thinks that my son George would be so much pleased at undertaking the work for me, that I will write to him, and so probably shall have no occasion to trouble you. If on still further reflection, and after looking over my notes, I think that my son could not do the work, I will write again and gratefully accept your proposal. But if you do not hear, you will understand that I can manage the affair myself. I never in my lifetime regretted an interruption so much as this new edition of the "Descent." I am deeply immersed in some work on physiological points with plants.

I fully agree with what you say about $H$. Spencer's "Sociology"; I do not believe there is a man in Europe at all his equal in talents. I did not know that you had been writing on politics, except so far as your letter on the coal question, which interested me much and struck me as a capital letter. 


\section{Alfred Russel Wallace}

I must again thank you for your letter, and remain, dear Wallace, yours very sincerely,

Ch. Darwin.

I hope to Heaven that politics will not replace natural science.

I know too well how atrociously bad my handwriting is.

The Dell, Grays, Essex. December 6, 1874.

Dear Darwin,-Many thanks for your kindness in sending me a copy of your new edition of the "Descent." I see you have made a whole host of additions and corrections which I shall have great pleasure in reading over as soon as I have got rid of my horrid book on Geographical Distribution, which is almost driving me mad with the amount of drudgery required and the often unsatisfactory nature of the result. However, I must finish with it soon, or all the part first done will have to be done over again, every new book, either as a monograph, or a classification, putting everything wrong (for me).

Hoping you are in good health and able to go on with your favourite work, I remain yours very sincerely,

AlfRed R. Wallace.

The Dell, Grays, Essex. July 21, 1875.

Dear Darwin,-Many thanks for your kindness in sending me a copy of your new book. ${ }^{1}$ Being very busy $I$ have only had time to dip into it yet. The account of Utricularia is most marvellous, and quite new to me. I'm rather surprised that you do not make any remarks on the origin of these extraordinary contrivances for capturing insects. Did you think they were too obvious? I daresay there is no difficulty, but $I$ feel sure they will be seized on as inexplicable by Natural Selection, and your silence on the

1 "Insectivorous Plants." 


\section{The Wallace-Darwin Correspondence}

point will be held to show that you consider them so? The contrivance in Utricularia and Dionæa, and in fact in Drosera too, seems fully as great and complex as in Orchids, but there is not the same motive force. Fertilisation and cross-fertilisation are important ends enough to lead to any modification, but can we suppose mere nourishment to be so important, seeing that it is so easily and almost universally obtained by extrusion of roots and leaves? Here are plants which lose their roots and leaves to acquire the same results by infinitely complex modes! What a wonderful and long-continued series of variations must have led up to the perfect "trap" in Utricularia, while at any stage of the process the same end might have been gained by a little more development of roots and leaves, as in 9,999 plants out of 10,000 !

Is this an imaginary difficulty, or do you mean to deal with it in future editions of the "Origin"?-Believe me yours very faithfully,

AlfRed R. Wallace.

The Dell, Grays, Essex. November 7, 1875.

Dear Darwin,--Many thanks for your beautiful little volume on "Climbing Plants," which forms a most interesting companion to your "Orchids" and "Insectivorous Plants." I am sorry to see that you have not this time given us the luxury of cut edges.

I am in the midst of printing and proof-sheets, which are wearisome in the extreme from the mass of names and statistics I have been obliged to introduce, and which will, I fear, make my book insufferably dull to all but zoological specialists.

My trust is in my pictures and maps to catch the public.

Hoping yourself and all your family are quite well, believe me yours very faithfully, ALFred R. WALlace. 


\section{Alfred Russel Wallace}

Down, Beckenham, Kent. June 5, 1876.

My dear Wallace,-I must have the pleasure of expressing to you my unbounded admiration of your book, though I have read only to page 184 - my object having been to do as little as possible while resting. I feel sure that you have laid a broad and safe foundation for all future work on Distribution. How interesting it will be to see hereafter plants treated in strict relation to your views; and then all insects, pulmonate molluscs, and fresh-water fishes, in greater detail than I suppose you have given to these lower animals. The point which has interested me most, but I do not say the most valuable point, is your protest against sinking imaginary continents in a quite reckless manner, as was started by Forbes, followed, alas, by Hooker, and caricatured by Wollaston and Murray. By the way, the main impression which the latter author has left on my mind is his utter want of all scientific judgment. I have lifted up my voice against the above view with no avail, but I have no doubt that you will succeed, owing to your new arguments and the coloured chart. Of a special value, as it seems to me, is the conclusion that we must determine the areas chiefly by the nature of the mammals. When I worked many years ago on this subject, I doubted much whether the now-called Palearctic and Nearctic regions ought to be separated; and I determined if $I$ made another region that it should be Madagascar. I have therefore been able to appreciate the value of your evidence on these points. What progress Palæontology has made during the last 20 years! But if it advances at the same rate in the future, our views on the migration and birthplace of the various groups will, I fear, be greatly altered. I cannot feel quite easy about 1 "The Geographical Distribution of Animals." 1876. 


\section{The Wallace-Darwin Correspondence}

the Glacial period and the extinction of large mammals, but I much hope that you are right. I think you will have to modify your belief about the difficulty of dispersal of land molluscs; I was interrupted when beginning to experimentise on the just-hatched young adhering to the feet of ground-roosting birds. I differ on one other point, viz. in the belief that there must have existed a Tertiary Antarctic continent, from which various forms radiated to the southern extremities of our present continents. But I could go on scribbling for ever. You have written, as I believe, a grand and memorable work, which will last for years as the foundation for all future treatises on Geographical Distribution.-My dear Wallace, yours very sincerely,

Charles Darwin.

P.S.-You have paid me the highest conceivable compliment by what you say of your work in relation to my chapters on Distribution in the "Origin," and I heartily thank you for it.

The Dell, Grays, Essex. June 7, 1876.

Dear Darwin,-Many thanks for your very kind letter. So few people will read my book at all regularly, that a criticism from one who does so will be very welcome.

If, as I suppose, it is only to p. 184 of Vol. I. that you have read, you cannot yet quite see my conclusions on the points you refer to (land molluscs and Antarctic continent). My own conclusions fluctuated during the progress of the book, and I have, I know, occasionally used expressions (the relics of earlier ideas) which are not quite consistent with what I say further on. I am positively against any Southern continent as uniting South America with Australia or New Zealand, as you will see at Vol. I., pp. 398-403 and 459-466. My general conclusions 


\section{Alfred Russel Wallace}

as to Distribution of Land Mollusca ${ }^{1}$ are at Vol. II., pp. 522-529. When you have read these passages and looked at the general facts which lead to them, I shall be glad to hear if you still differ from me.

Though, of course, present results as to origin and migrations of genera of mammals will have to be modified owing to new discoveries, I cannot help thinking that much will remain unaffected, because in all geographical and geological discoveries the great outlines are soon reached; the details alone remain to be modified. I also think much of the geological evidence is now so accordant with, and explanatory of, geographical distribution that it is prima facie correct in outline. Nevertheless, such vast masses of new facts will come out in the next few years that I quite dread the labour of incorporating them in a new edition.

Now for a little personal matter. For two years I have made up my mind to leave this place-mainly for two reasons : drought and wind prevent the satisfactory growth of all delicate plants; and I cannot stand being unable to attend evening meetings and being obliged to refuse every invitation in London. But I was obliged to stay till I had got it into decent order to attract a customer. At last it is so, and $I$ am offering it for sale, and as soon as it is disposed of $I$ intend to try the neighbourhood of Dorking, whence there are late trains from Cannon street and Charing Cross.

I see your post-mark was Dorking, so I suppose you have been staying there. Is it not a lovely country? I hope your health is improved, and when, quite at your

1 Wallace points out that " hardly a small island on the globe but has some land shell peculiar to it," and he goes so far as to say that probably air-breathing mollusca have been chiefly distributed by air- or water-carriage, rather than by voluntary dispersal on the land. See "More Letters," ii. 14. 


\section{The Wallace-Darwin Correspondence}

leisure, you have waded through my book, I trust you will again let me have a few lines of friendly criticism and advice.-Yours very faithfully,

AlFRed R. WALlace.

Down, Beckenham. June 17, 1876.

My dear Wallace,-I have now finished the whole of Vol. I., with the same interest and admiration as before; and I am convinced that my judgment was right and that it is a memorable book, the basis of all future work on the subject. I have nothing particular to say, but perhaps you would like to hear my impressions on two or three points. Nothing has struck me more than the admirable and convincing manner in which you treat Java. To allude to a very trifling point, it is capital about the unadorned head of the Argus pheasant. ${ }^{2}$ How plain a thing is, when it is once pointed out! What a wonderful case is that of Celebes! I am glad that you have slightly modified your views with respect to Africa," and this leads me to say that I cannot swallow the so-called continent of Lemuria, i.e. the direct connection of Africa and Ceylon! ${ }^{3}$ The facts do not seem to me many and strong enough to justify so immense a change of level. Moreover, Mauritius and the other islands appear to me oceanic in character. But do not suppose

1 See "The Descent of Man," 1st Edit., pp. 90 and 143, for drawings of the Argus pheasant and its markings. The ocelli on the wing feathers were favourite objects of Darwin's, and sometimes formed the subject of the little lectures which on rare occasions he would give to a visitor interested in Natural History. In Wallace's book, the meaning of the ocelli comes in by the way, in the explanation of Plate IX., "A Malayan Forest with some of its Peculiar Birds." The case is a "remarkable confirmation of Mr. Darwin's views, that gaily coloured plumes are developed in the male bird for the purpose of attractive display."

2 "Geographical Distribution of Animals," i. 286-7.

" Geographical Distribution," 1. 76. The name Lemuria was proposed by Mr. Sclater for an imaginary submerged continent extending from Madagascar to Ceylon and Sumatra. Wallace points out that if we confine ourselves to facts Lemuria is reduced to Madagascar, which he makes a subdivision of the Ethiopian Region. 


\section{Alfred Russel Wallace}

that I place my judgment on this subject on a level with yours. A wonderfully good paper was published about a year ago on India in the Geological Journal-I think by. Blandford:1 Ramsay agreed with me that it was one of the best published for a long time. The author shows that India has been a continent with enormous fresh-water lakes from the Permian period to the present day. If I remember right he believes in a former connection with South Africa.

I am sure that I read, some 20 to 30 years ago, in a French journal, an account of teeth of mastodon found in Timor; but the statement may have been an error.

With respect to what you say about the colonising of New Zealand, I somewhere have an account of a frog frozen in the ice of a Swiss glacier, and which revived when thawed. I may add that there is an Indian toad which can resist salt water and haunts the seaside. Nothing ever astonished me more than the case of the Galaxias; but it does not seem known whether it may not be a migratory fish like the salmon. It seems to me that you complicate rather too much the successive colonisations with New Zealand. I should prefer believing that the Galaxias was a species, like the Emys of the Sewalik Hills, which has long retained the same form. Your remarks on the insects and flowers of New Zealand have greatly interested me; but aromatic leaves I have always looked at as a protection against their being eaten by insects or other animals; and as insects are there rare, such protection would not be much needed. I have written more than $I$ intended, and I must again say how profoundly your book has interested me.

Now let me turn to a very different subject. I have

1 H. F. Blandford, "On the Age and Correlations of the Plant-bearing Series of India and the Former Existence of an Indo-Oceanic Continent" (Quart. Journ. Geol. Soc., 1875, xxxi. 519). 


\section{The Wallace-Darwin Correspondence}

only just heard of and procured your two articles in the Academy. I thank you most cordially for your generous defence of me against Mr. Mivart. In the "Origin" I did not discuss the derivation of any one species; but that $I$ might not be accused of concealing my opinion I went out of my way and inserted a sentence which seemed to me (and still so seems) to declare plainly my belief. This was quoted in my "Descent of Man." Therefore it is very unjust, not to say dishonest, of Mr. Mivart to accuse me of base fraudulent concealment; I care little about myself; but Mr. Mivart, in an article in the Quarterly Review (which I know was written by him), accused my son George of encouraging profligacy, and this without the least foundation." I can assert this positively, as I laid George's article and the Quarterly Review before Hooker, Huxley and others, and all agreed that the accusation

1 In the Contemporary Review for August, 1873, Mr. George Darwin wrote an article " On Beneflcial Restrictions to Liberty of Marriage." In the July number of the Quarterly Review, 1874, p. 70, in an article entitled " Primitive Man-Tylor and Lubbock," Mr. Mivart thus referred to Mr. Darwin's article : "Elsewhere (pp. 424-5) Mr. George Darwin speaks (1) in an approving strain of the most oppressive laws and of the encouragement of vice to check population. (2) There is no sexual criminality of Pagan days that might not be defended on the principles advocated by the school to which this writer belongs." In the Quarterly Review for October, 1874, p. 587, appeared a letter from Mr. George Darwin " absolutely denying " charge No. 1, and with respect to charge No. 2 he wrote: "I deny that there is any thought or word in my essay which could in any way lend itself to the support of the nameless crimes here referred to." To the letter was appended a note from Mr. Mivart, in which he said : "Nothing would have been further from our intention than to tax Mr. Darwin personally (as he seems to have supposed) with the advocacy of laws or acts which he saw to be oppressive or vicious. We, therefore, most willingly accept his disclaimer, and are glad to find that he does not, in fact, apprehend the full tendency of the doctrines which he has helped to propagate. Nevertheless, we cannot allow that we have enunciated a single proposition which is either 'false' or 'groundless.' . . . But when a writer, according to his own confession, comes before the public 'to attack the institution of marriage' ... he must expect searching criticism; and, without implying that Mr. Darwin has in 'thought' or 'word " approved of anything which he wishes to disclaim, we must still maintain that the doctrines which he advocates are most dangerous and pernicious."-EDrroR. 


\section{Alfred Russel Wallace}

was a deliberate falsification. Huxley wrote to him on the subject and has almost or quite cut him in consequence; and so would Hooker, but he was advised not to do so as President of the Royal Society. Well, he has gained his object in giving me pain, and, good God, to think of the flattering, almost fawning speeches which he has made to me! I wrote, of course, to him to say that I would never speak to him again. I ought, however, to be contented, as he is the one man who has ever, as far as I know, treated me basely.

Forgive me for writing at such length, and believe me yours very sincerely,

CH. Darwin.

P.S.-I am very sorry that you have given up sexual selection. I am not at all shaken, and stick to my colours like a true Briton. When $I$ think about the unadorned head of the Argus pheasant, I might exclaim, Et $t u$, Brute!

Down, Beckenham. June 25, 1876.

My dear Wallace,-I have been able to read rather more quickly of late and have finished your book. I have not much to say. Your careful account of the temperate parts of South America interested me much, and all the more from knowing something of the country. I like also much the general remarks towards the end of the volume on the land molluscs. Now for a few criticisms.

P. $122:^{1}$ I am surprised at your saying that "during the whole Tertiary period North America was zoologically far more strongly contrasted with South America than it is now." But we know hardly anything of the latter except during the Pliocene period, and then the mastodon, horse, several great Dentata, etc. etc., were common to the North and South. If you are right I erred greatly in

1 The pages refer to Vol. II. of Wallace's " Geographical Distribution." 


\section{The Wallace-Darwin Correspondence}

my Journal, where I insisted on the former close connection between the two.

P. 252, and elsewhere: I agree thoroughly with the general principle that a great area with many competing forms is necessary for much and high development; but do you not extend this principle too far-I should say much too far, considering how often several species of the same genus have been developed on very small islands?

P. 265 : You say that the Sittidæ extend to Madagascar, but there is no number in the tabular heading.

P. 359: Rhinochetus is entered in the tabular heading under No. 3 of the Neotropical sub-regions. ${ }^{2}$

Reviewers think it necessary to find some fault, and if I were to review you, the sole point which I should blame is your not giving very numerous references. These would save whoever follows you great labour. Occasionally I wished myself to know the authority for certain statements, and whether you or somebody else had originated certain subordinate views. Take the case of a man who had collected largely on some island, for instance St. Helena, and who wished to work out the geographical relations of his collection; he would, I think, feel very blank at not finding in your work precise references to all that had been written on St. Helena. I hope you will not think me a confoundedly disagreeable fellow.

I may mention a capital essay which $I$ received a few months ago from Axel Blytt' on the distribution of the plants of Scandinavia; showing the high probability of there having been secular periods alternately wet and dry; and of the important part which they have played in distribution.

2 The number (4) was erroneously omitted.-A. R. W.

An error : should have been the Australian.-A. R. W.

"Axel Blytt, "Essay on the Immigration of the Norwegian Flora." Christiania, 1876. 


\section{Alfred Russel Wallace}

I wrote to Forel, who is always at work on ants, and told him of your views about the dispersal of the blind Coleoptera, and asked him to observe.

I spoke to Hooker about your book, and feel sure that he would like nothing better than to consider the distribution of plants in relation to your views; but he seemed to doubt whether he should ever have time.

And now I have done my jottings, and once again congratulate you on having brought out so grand a work. I have been a little disappointed at the review in Nature. My dear Wallace, yours sincerely,

Charles Darwin.

Rose Hill, Dorking. July 23, 1876.

My dear Darwin,-I should have replied sooner to your last kind and interesting letters, but they reached me in the midst of my packing previous to removal here, and I have only just now got my books and papers in a get-atable state.

And first, many thanks for your close observation in detecting the two absurd mistakes in the tabular headings.

As to the former greater distinction of the North and South American faunas, I think I am right. The Edentata, being proved (as I hold) to have been mere temporary migrants into North America in the post-Pliocene epoch, form no part of its Tertiary fauna. Yet in South America they were so enormously developed in the Pliocene epoch that we know, if there is any such thing as Evolution, etc., that strange ancestral forms must have preceded them in Miocene times.

Mastodon, on the other hand, represented by one or two species only, appears to have been a late immigrant into South America from the North.

The immense development of Ungulates (in varied 1 June 22, 1876, p. 165 et seq. 


\section{The Wallace-Darwin Correspondence}

families, genera, and species) in North America during the whole Tertiary epoch is, however, the great feature, which assimilates it to Europe and contrasts it with South America. True camels, hosts of hog-like animals, true rhinoceroses, and hosts of ancestral horses, all bring North America much nearer to the old World than it is now. Even the horse, represented in all South America by Equus only, was probably a temporary immigrant from the North.

As to extending too far the principle (yours) of the necessity of comparatively large areas for the development of varied faunas, I may have done so, but I think not. There is, I think, every probability that most islands, etc., where a varied fauna now exists have been once more extensive, e.g. New Zealand, Madagascar. Where there is no such evidence (e.g. Galapagos), the fauna is very restricted.

Lastly as to want of references; I confess the justice of your criticism. But I am dreadfully unsystematic. It is my first large work involving much of the labour of others. I began with the intention of writing a comparatively short sketch, enlarged it, and added to it, bit by bit; remodelled the tables, the headings, and almost everything else, more than once, and got my materials into such confusion that it is a wonder it has not turned out far more crooked and confused than it is. I, no doubt, ought to have given references; but in many cases I found the information so small and scattered, and so much had to be combined and con. densed from conflicting authorities, that I hardly knew how to refer to them or where to leave off. Had I referred to all authors consulted for every fact, I should have greatly increased the bulk of the book, while a large portion of the references would be valueless in a few years owing to later and better authorities. My experience of referring to refer. ences has generally been most unsatisfactory. One finds, 


\section{Alfred Russel Wallace}

nine times out of ten, the fact is stated, and nothing more; or a reference to some third work not at hand!

I wish I could get into the habit of giving chapter and verse for every fact and extract, but $I$ am too lazy and generally in a hurry, having to consult books against time when in London for a day.

However, I will try and do something to mend this matter should I have to prepare another edition.

I return you Forel's letter. It does not advance the question much, neither do I think it likely that even the complete observation he thinks necessary would be of much use; because it may well be that the ova or larvæ or imagos of the beetles are not carried systematically by the ants, but only occasionally owing to some exceptional circum. stances. This might produce a great effect in distribution, yet be so rare as never to come under observation.

Several of your remarks in previous letters I shall carefully consider. I know that, compared with the extent of the subject, my book is in many parts crude and ill-considered; but $I$ thought, and still think, it better to make some generalisations wherever possible, as I am not at all afraid of having to alter my views in many points of detail. I was so overwhelmed with zoological details that I never went through the Geological Society's Journal as I ought to have done, and as I mean to do before writing more on the subject.

With best wishes, believe me yours very faithfully,

'Alfred R. Wallach.

Rose Hill, Dorking. December 13, 1876.

My dear Darwin,-Many thanks for your new book on "Crossing Plants," which I have read with much interest. I hardly expected, however, that there would have been so many doubtful and exceptional cases. I fancy that the 296 


\section{The Wallace-Darwin Correspondence}

results would have come out better had you always taken weights instead of heights; and that would have obviated the objection that will, I daresay, be made, that height proves nothing, because a tall plant may be weaker, less bulky and less vigorous than a shorter one. Of course no one who knows you or who takes a general view of your results will say this, but I daresay it will be said. I am afraid this book will not do much or anything to get rid of the one great objection, that the physiological characteristic of species, the infertility of hybrids, has not yet been produced. Have you ever tried experiments with plants (if any can be found) which for several centuries have been grown under very different conditions, as for instance potatoes on the high Andes and in Ireland? If any approach to sterility occurred in mongrels between these it would be a grand step. The most curious point you have brought out seems to me the slight superiority of self-fertilisation over fertilisation with another flower of the same plant, and the most important result, that difference of constitution is the essence of the benefit of cross-fertilisation. All you now want is to find the neutral point where the benefit is at its maximum, any greater difference being prejudicial.

Hoping you may yet demonstrate this, believe me yours very faithfully,

Alfred R. Wallace.

Rose Hill, Dorking. January 17, 1877.

My dear Darwin,-Many thanks for your valuable new edition of the "Orchids," which I see contains a great deal of new matter of the greatest interest. I am amazed at your continuous work, but I suppose, after all these years of it, it is impossible for you to remain idle. I, on the contrary, am very idle, and feel inclined to do nothing but stroll about this beautiful country, and read all kinds of miscellaneous literature. 


\section{Alfred Russel Wallace}

I have asked my friend Mr. Mott to send you the last of his remarkable papers-on Haeckel. But the part I hope you will read with as much interest as $I$ have done is that on the deposits of Carbon, and the part it has played and must be playing in geological changes. He seems to have got the idea from some German book, but it seems to me very important, and $I$ wonder it never occurred to Sir Charles Lyell. If the calculations as to the quantity of undecomposed carbon deposited are anything approaching to correctness, the results must be important.

Hoping you are in pretty good health, believe me yours very faithfully,

ALFRED R. WALLACE.

Rose Hill, Dorking. July 23, 1877.

My dear Darwin,-Many thanks for your admirable volume on "The Forms of Flowers." It would be impertinence of me to say anything in praise of it, except that I have read the chapters on "Illegitimate Offspring of Heterostyled Plants" and on "Cleistogamic Flowers" with great interest.

I am almost afraid to tell you that in going over the subject of the Colours of Animals, etc., for a small volume of essays, etc., I am preparing, I have come to conclusions directly opposed to voluntary sexual selection, and believe that I can explain (in a general way) all the phenomena of sexual ornaments and colours by laws of development aided by simple Natural Selection.

I hope you admire as I do Mr. Belt's remarkable series of papers in support of his terrific "oceanic glacier riverdamming" hypothesis. In awful grandeur it beats everything "glacial" yet out, and it certainly explains a wonderful lot of hard facts. The last one, on the "Glacial Period in the Southern Hemisphere," in the Quarterly Journal of Science, is particularly fine, and I see he has 


\section{The Wallace-Darwin Correspondence}

just read a paper at the Geological Society. It seems to me supported by quite as much evidence as Ramsay's "Lakes"; but Ramsay, I understand, will have none of it -as yet.-Believe me yours very faithfully,

\section{Alfred R. Wallact.}

Down, Beckenham, Kent. August 31, 1877.

My dear Wallace,-I am very much obliged to you for sending your article, which is very interesting and appears to me as clearly written as it can be. You will not be surprised that I differ altogether from you about sexual colours. That the tail of the peacock and his elaborate display of it should be due merely to the vigour, activity, and vitality of the male is to me as utterly incredible as my views are to you. Mantegazza published a few years ago in Italy a somewhat similar view. I cannot help doubting about recognition through colour: our horses, dogs, fowls, and pigeons seem to know their own species, however differently the individuals may be coloured. I wonder whether you attribute the odoriferous and sound-producing organs, when confined to the males, to their greater vigour, etc.? I could say a good deal in opposition to you, but my arguments would have no weight in your eyes, and I do not intend to write for the public anything on this or any other difficult subject. By the way, I doubt whether the term voluntary in relation to sexual selection ought to be employed : when a man is fascinated by a pretty girl it can hardly be called voluntary, and I suppose that female animals are charmed or excited in nearly the same manner by the gaudy males.

Three essays have been published lately in Germany which would interest you : one by Weismann, who shows that the coloured stripes on the caterpillars of Sphinx are beautifully protective : and birds were frightened away 


\section{Alfred Russel Wallace}

from their feeding-place by a caterpillar with large eyelike spots on the broad anterior segments of the body. Fritz Müller has well discussed the first steps of mimicry with butterflies, and comes to nearly or quite the same conclusion as you, but supports it by additional arguments.

Fritz Müller also has lately shown that the males alone of certain butterflies have odoriferous glands on their wings (distinct from those which secrete matter disgusting to birds), and where these glands are placed the scales assume a different shape, making little tufts.

Farewell : I hope that you find Dorking a pleasant place ? I was staying lately at Abinger Hall, and wished to come over to see you, but driving tires me so much that my courage failed.-Yours very sincerely,

Chas. Darwin.

Madeira Villa, Madeira Road, Ventnor, Isle of Wight. September 3, 1877.

My dear Darwin,-Many thanks for your letter. Of course I did not expect my paper to have any effect on your opinions. You have looked at all the facts so long from your special point of view that it would require conclusive arguments to influence you, and these, from the complex nature of the question, are probably not to be had. We must, I think, leave the case in the hands of others, and I am in hopes that my paper may call sufficient attention to the subject to induce some of the great school of Darwinians to take the question up and work it out thoroughly. You have brought such a mass of facts to support your view, and have argued it so fully, that I hardly think it necessary for you to do more. Truth will prevail, as you as well as I wish it to do. I will only make one or two remarks. The word "voluntary" was inserted in my proofs only, in order to distinguish clearly between 


\section{The Wallace-Darwin Correspondence}

the two radically distinct kinds of "sexual selection." Perhaps "conscious" would be a better word, to which I think you will not object, and I will alter it when I republish. I lay no stress on the word "voluntary."

Sound-and scent-producing organs in males are surely due to "natural" or "automatic" as opposed to "conscious" selection. If there were gradations in the sounds produced, from mere noises, up to elaborate music-the case would be analogous to that of "colours" and "ornament." Being, however, comparatively simple, Natural Selection, owing to their use as a guide, seems sufficient. The louder sound, heard at a greater distance, would attract or be heard by more females, or it may attract other males and lead to combats for the females, but this would not imply. choice in the sense of rejecting a male whose stridulation was a trifle less lond than another's, which is the essence of the theory as applied by you to colour and ornament. But greater general vigour would almost certainly lead to greater volume or persistence of sound, and so the same view will apply to both cases on my theory.

Thanks for the references you give me. My ignorance of German prevents me supporting my views by the mass of observations continually being made abroad, so I can only advance my own ideas for what they are worth.

I like Dorking much, but can find no house to suit me, so fear I shall have to move again.

With best wishes, believe me yours very faithfully,

ALERED R. WALLACE.

Down, Beckenham, Kent. September 5, [1877].

My dear Wallace,-- "Conscious" seems to me much better than "voluntary." Conscious action, I presume, comes into play. when two males fight for a female; but I 


\section{Alfred Russel Wallace}

do not know whether you admit that, for instance, the spur of the cock is due to sexual selection.

I am quite willing to admit that the sounds and vocal organs of some males are used only for challenging, but I doubt whether this applies to the musical notes of Hylobates or to the howling (I judge chiefly from Rengger) of the American monkeys. No account that I have seen of the stridulation of male insects shows that it is a challenge. All those who have attended to birds consider their song as a charm to the females and not as a challenge. As the males in most cases search for the females I do not see how their odoriferous organs will aid them in finding the females. But it is foolish in me to go on writing, for I believe I have said most of this in my book: anyhow, I well remember thinking over it. The "belling" of male stags, if I remember rightly, is a challenge, and so I daresay is the roaring of the lion during the breeding season.

I will just add in reference to your former letter that I fully admit that with birds the fighting of the males co-operates with their charms; and I remember quoting Bartlett that gaudy colouring in the males is almost invariably concomitant with pugnacity. But, thank Heaven, what little more I can do in science will be confined to observation on simple points. However much I may have blundered, I have done my best, and that is my constant comfort. -Most truly yours,

C. DARWIN.

Waldron Edge, Duppas Hill, Croydon. September 14, 1878.

Dear Darwin,-An appointment is soon to be made of someone to have the superintendence of Epping Forest under the new Act, and as it is a post which of all others I should like I am trying very hard to get up interest enough to secure it. 


\section{The Wallace-Darwin Correspondence}

One of the means is the enclosed memorial, which has been already signed by Sir J. Hooker and Sir J. Lubbock, and to which I feel sure you will add your name, which I expect has weight "even in the City."

In want of anything better to do I have been grinding away at a book on the Geography of Australia for Stanford for the last six months.

Hoping you are in good health, and with my best compliments to Mrs. Darwin and the rest of your family, believe me yours very faithfully,

ALFRED R. WALLACE.

Down, Beckenham, Kent. September 16, 1878.

My dear Wallace,-I return the paper signed, and most heartily wish that you may be successful, not only for your own sake, but for that of Natural Science, as you would then have more time for new researches.

I keep moderately well, but always feel half-dead, yet manage to work away on vegetable physiology, as I think that I should die outright if I had nothing to do.-Believe me yours very sincerely,

Ch. Darwin.

Waldron Edge, Duppas Hill, Croydon. September 23, 1878.

Dear Darwin,-Many thanks for your signature and good wishes. I have some hopes of success, but am rather doubtful of the Committee of the Corporation who will have the management, for they have just decided after a great struggle in the Court of Common Council that it is to be a rotatory Committee, every member of the Council (of whom there are 200) coming on it in succession if they please. They evidently look upon it as a Committee which will have great opportunities of excursions, picnics, and dinners, at the expense of the Corporation, while the improvement of the Forest will be quite a secondary matter. 


\section{Alfred Russel Wallace}

I am very glad to hear you are tolerably well. It is all I can say of myself.-Believe me yours very faithfully,

ALFRED R. WALLACB.

Down, Beckenham, Kent. January 5, 1880.

My dear Wallace,-As this note requires no sort of answer, you must allow me to express my lively admira. tion of your paper in the Nineteenth Century. ${ }^{2}$ You certainly are a master in the difficult art of clear exposition. It is impossible to urge too often that the selection from a single varying individual or of a single varying organ will not suffice. You have worked in capitally Allen's admirable researches. As usual, you delight to honour me more than I deserve. When $I$ have written about the extreme slowness of Natural Selection (in which I hope I may be wrong), I have chiefly had in my mind the effects of intercrossing. I subscribe to almost everything you say excepting the last short sentence.

And now let me add how grieved I was to hear that the City of London did not elect you for the Epping office, but I suppose it was too much to hope that such a body of men should make a good selection. I wish you could obtain some quiet post and thus have leisure for moderate scientific work. I have nothing to tell you about myself; I see few persons, for conversation fatigues me much ; but I daily do some work in experiments on plants, and hope thus to continue to the end of my days.

With all good wishes, believe me yours very sincerely,

Charles Darwin.

P.S.-Have you seen Mr. Farrer's article in the last H'ortnightly? It reminded me of an article on bequests by you some years ago which interested and almost converted me.

1 "The Origin of Species and Genera." 


\section{The Wallace-Darwin Correspondence}

Waldron Edge, Duppas Hill, Croydon. January 9, 1880.

My dear Darwin,-It is a great pleasure to receive a letter from you sometimes-especially when we do not differ very much. I am, of course, much pleased and gratified that you like my article. I wrote it chiefly because 1 thought there was something a little fresh still to say on the subject, and also because I wished to define precisely my present position, which people continually misunderstand. The main part of the article forms part of a chapter of a book $I$ have now almost finished on my favourite subject of "Geographical Distribution." It will form a sort of supplement to my former work, and will, I trust, be more readable and popular. I go pretty fully into the laws of variation and dispersal; the exact character of specific and generic areas, and their causes; the growth, dispersal and extinction of species and groups, illustrated by maps, etc.; changes of geography and of climate as affecting dispersal, with a full discussion of the Glacial theory, adopting Croll's views (part of this has been published as a separate article in the Quarterly Review of last July, and has been highly approved by Croll and Geikie); a discussion of the theory of permanent continents and oceans, which I see you were the first to adopt, but which geologists, I am sorry to say, quite ignore. All this is preliminary. Then follows a series of chapters on the different kinds of islands, continental and oceanic, with a pretty full discussion of the characters, affinities, and origin of their fauna and flora in typical cases. Among these I am myself quite pleased with my chapters on New Zealand, as I believe I have fully explained and accounted for all the main peculiarities of the New Zealand and Australian floras. I call the book "Island Life," etc. etc., and I think it will be interesting. 


\section{Alfred Russel Wallace}

Thanks for your regrets and kind wishes anent Epping. It was a disappointment, as I had good friends on the Committee and therefore had too much hope. I may just mention that I am thinking of making some application through friends for some post in the new Josiah Mason College of Science at Birmingham, as Registrar or Curator and Librarian, etc. The Trustees have advertised for Professors to begin next October. Should you happen to know any of the Trustees, or have any influential friends in Birmingham, perhaps you could help me.

I think this book will be my last, as I have pretty well said all I have to say in it, and I have never taken to experiment as you have. But I want some easy occupation for my declining years, with not too much confinement or desk-work, which I cannot stand. You see I had some reason for writing to you; but do not you trouble to write again unless you have something to communicate.

With best wishes, yours very faithfully,

AlFRed R. WaLlact.

I have not seen the Fortnightly yet, but will do so.

Pen-y-bryn, St. Peter's Road, Croydon. October 11, 1880.

My dear Darwin,-I hope you will have received a copy of my last book, "Island Life," as I shall be very glad of your opinion on certain points in it. The first five chapters you need not read, as they contain nothing fresh to you, but are necessary to make the work complete in itself. The next five chapters, however (VII. to X.), I think, will interest you. As I think, in Chapters VIII. and IX. I have found the true explanation of geological climates, and on this I shall be very glad of your candid opinion, as it is the very foundation-stone of the book. The rest will not contain much that is fresh to you, except the three chapters 


\section{The Wallace-Darwin Correspondence}

on New Zealand. Sir Joseph Hooker thinks my theory of the Australian and New Zealand floras a decided advance on anything that has been done before.

In connection with this, the chapter on the Azores should be read.

Chap. XVI. on the British Fauna may also interest you.

I mention these points merely that you may not trouble yourself to read the whole book, unless you like.

Hoping that you are well, believe me yours very faithfully,

Alfred R. Wallact.

Down, Beckenham, Kent. November 3, 1880.

My dear Wallace,-I have now read your book, ${ }^{2}$ and it has interested me deeply. It is quite excellent, and seems to me the best book which you have ever published; but this may be merely because $I$ have read it last. As I went on, I made a few notes, ${ }^{2}$ chiefly when I differed strongly from you; but God knows whether they are worth your reading. You will be disappointed with many of them;

1 " Island Life."

2 In "My Life" (ii. 12-13) Wallace writes: "With this came seven foolscap pages of notes, many giving facts from his extensive reading which $I$ had not seen. There were also a good many doubts and suggestions on the very difficult questions in the discussion of the causes of the glacial epochs. Chapter XXIII., discussing the Arctic element in South Temperate floras, was the part he most objected to, saying, "This is rather too speculative for my old noddle. I must think that you overrate the importance of new surfaces on mountains and dispersal from mountain to mountain. I still believe in alpine plants having lived on the lowlands and in the southern tropical regions having been cooled during glacial periods, and thus only can I understand character of floras on the isolated African mountains. It appears to me that you are not justified in arguing from dispersal to oceanic islands to mountains. Not only in latter cases currents of sea are absent, but what is there to make birds fly direct from one alpine summit to another? There is left only storms of wind, and if it is probable or possible that seeds may thus be carried for great distances, I do not believe that there is at present any evidence of their being thus carried more than a few miles.' This is the most connected piece of criticism in the notes, and I therefore give it verbatim." 


\section{Alfred Russel Wallace}

but they will show that I had the will, though I did not know the way, to do what you wanted.

I have said nothing on the infinitely many passages and views which I admired and which were new to me. My notes are badly expressed; but $I$ thought that you would excuse my taking any pains with my style. I wish that my confounded handwriting was better.

I had a note the other day from Hooker, and I can see that he is much pleased with the Dedication.

With all good wishes, believe me yours sincerely,

\section{Ch. Darwin.}

In two or three weeks you will receive a book from me; if you care to know what it is about, read the paragraph in Introduction about new terms and then the last chapter, and you will know whole contents of book.

Pen-y-bryn, St. Peter's Road, Croydon. November 8, 1880.

My dear Darwin,-Many thanks for your kind remarks and notes on my book. Several of the latter will be of use to me if $I$ have to prepare a second edition, which $I$ am not so sure of as you seem to be.

1. In your remark as to the doubtfulness of paucity of fossils being due to coldness of water, I think you overlook that I am speaking only of waters in the latitude of the Alps, in Miocene and Eocene times, when icebergs and glaciers temporarily descended into an otherwise warm sea; my theory being that there was no glacial epoch at that time, but merely a local and temporary descent of the snow-line and glaciers owing to high excentricity and winter in aphelion.

2. I cannot see the difficulty about the cessation of the glacial period. Between the Miocene and the Pleistocene periods geographical changes occurred which rendered a 308 


\section{The Wallace-Darwin Correspondence}

true glacial period possible with high excentricity. When the high excentricity passed away the glacial epoch also passed away in the Temperate zone; but it persists in the Arctic zone, where during the Miocene there were mild climates, and this is due to the persistence of the changed geographical conditions. The present Arctic climate is itself a comparatively new and abnormal state of things due to geographical modification. As to "epoch" and "period," I use them as synonyms to avoid repeating the same word.

3. Rate of deposit and geological time: there no doubt I may have gone to an extreme, but my " twenty-eight million years" may be anything under 100 millions, as I state. There is an enormous difference between mean and maximum denudation and deposition. In the case of the great faults the upheaval along a given line would itself facilitate the denudation (whether subaerial or marine) of the upheaved portion at a rate perhaps a hundred times faster than plains and plateaux. So, local subsidence might itself lead to very rapid deposition. Suppose a portion of the Gulf of Mexico near the mouth of the Mississippi were to subside for a few thousand years, it might receive the greater part of the sediment from the whole Mississippi valley, and thus form strata at a very rapid rate.

4. You quote the Pampas thistles, etc., against my statement of the importance of preoccupation. But I am referring especially to St. Helena, and to plants naturally introduced from the adjacent continents. Surely, if a certain number of African plants reached the island and became modified into a complete adaptation to its climatic conditions, they would hardly be expelled by other African plants arriving subsequently. They might be so conceivably, but it does not seem probable. The cases of the Pampas, New Zealand, Tahiti, etc., are very different, where highly 


\section{Alfred Russel Wallace}

developed aggressive plants have been artificially introduced. Under nature it is these very aggressive species that would first reach any island in their vicinity, and, being adapted to the island and colonising it thoroughly, would then hold their own against other plants from the same country, mostly less aggressive in character. I have not explained this so fully as I should have done in the book. Your criticism is therefore useful.

My Chap. XXIII. is no doubt very speculative, and I cannot wonder at your hesitating at accepting my views. To me, however, your theory of hosts of existing species migrating over the tropical lowlands from the North Temperate to the South Temperate zone appears more specula. tive and more improbable. For, where could the rich lowland equatorial flora have existed during a period of general refrigeration sufficient for this? and what became of the wonderfully rich Cape flora which, if the temperature of Tropical Africa had been so recently lowered, would certainly have spread northwards and on the return of the heat could hardly have been driven back into the sharply defined and very restricted area in which it now exists ?

As to the migration of plants from mountain to mountain not being so probable as to remote islands, I think that is fully counterbalanced by two considerations:

(a) The area and abundance of the mountain stations along such a range as the Andes are immensely greater than those of the islands in the North Atlantic, for example.

(b) The temporary occupation of mountain stations by migrating plants (which I think $I$ have shown to be probable) renders time a much more important element in increasing the number and variety of the plants so dispersed than in the case of islands, where the flora soon acquires a fixed and endemic character, and where the number of species is necessarily limited. 


\section{The Wallace-Darwin Correspondence}

No doubt, direct evidence of seeds being carried great distances through the air is wanted, but, I am afraid, can hardly be obtained. Yet I feel the greatest confidence that they are so carried. Take for instance the two peculiar orchids of the Azores (Habinaria species) : what other mode of transit is conceivable? The whole subject is one of great difficulty, but I hope my chapter may call attention to a hitherto neglected factor in the distribution of plants.

Your references to the Mauritius literature are very interesting, and will be useful to me; and again thanking you for your valuable remarks, believe me yours very faithfully,

Alfred R. Wallace.

Pen-y-bryn, St. Peter's Road, Croydon. November 21, 1880.

My dear Darwin,-Many thanks for your new book containing your wonderful series of experiments and observations on the movements of plants. I have read the introduction and conclusion, which shows me the importance of the research as indicating the common basis of the infinitely varied habits and mode of growth of plants. The whole subject becomes thus much simplified, though the nature of the basic vitality which leads to such wonderful results remains as mysterious as ever.-Yours very faithfully,

ALFRED R. WALLACE.

Pen-y-bryn, St. Peter's Road, Croydon. January 1, 1881.

My dear Darwin,-I have been intending to write to you for some weeks to call your attention to what seems to me a striking confirmation (or at all events a support) of my views of the land migration of plants from mountain to mountain. In Nature of Dec. 9th, p. 126, Mr. Baker, of Kew, describes a number of the alpine plants of Madagascar as being identical species with some found on the mountains of Abyssinia, the Cameroons, and other African 


\section{Alfred Russel Wallace}

mountains. Now, if there is one thing more clear than another it is that Madagascar has been separated from Africa since the Miocene (probably the early Miocene) epoch. These plants must therefore have reached the island either since then, in which case they certainly must have passed through the air for long distances, or at the time of the union. But the Miocene and Eocene periods were certainly warm, and these alpine plants could hardly have migrated over tropical forest lands, while it is very improbable that if they had been isolated at so remote a period, exposed to such distinct climatal and organic environments as in Madagascar and Abyssinia, they would have in both places retained their specific characters unchanged. The presumption is, therefore, that they are comparatively recent immigrants, and if so must have passed across the sea from mountain to mountain, for the richness and speciality of the Madagascar forest vegetation render it certain that no recent glacial epoch has seriously affected that island.

Hoping that you are in good health, and wishing you the compliments of the season, I remain yours very faithfully,

AlFred R. Wallace.

Down, Beckenham, Kent. January 2, 1881.

My dear Wallace,-The case which you give is a very striking one, and I had overlooked it in Nature. ${ }^{1}$ But I remain as great a heretic as ever. Any supposition seems to me more probable than that the seeds of plants should have been blown from the mountains of Abyssinia or other central mountains of Africa to the mountains of Madagascar. It seems to me almost infinitely more probable

1 "Nature, December 9, 1880. The substance of this article by Mr. Baker, of Kew, is given in 'More Letters,' vol. iii. 25, in a footnote."- " My Life," ji. 13. 


\section{The Wallace-Darwin Correspondence}

that Madagascar extended far to the south during the Glacial period, and that the southern hemisphere was, according to Croll, then more temperate; and that the whole of Africa was then peopled with some temperate forms, which crossed chiefly by agency of birds and seacurrents; and some few by the wind from the shores of Africa to Madagascar, subsequently ascending to the mountains.

How lamentable it is that two men should take such widely different views, with the same facts before them; but this seems to be almost regularly our case, and much do I regret it.

I am fairly well, but always feel half dead with fatigue. I heard but an indifferent account of your health some time ago, but trust that you are now somewhat stronger.-Believe me, my dear Wallace, yours very sincerely,

Ch. Darwin.

\section{Down, Beckenham, Kent. January 7, 1881.}

My dear Wallace,-You know from Miss Buckley that, with her assistance, I drew up a memorial to Mr. Gladstone with respect to your services to science. The memorial was corrected by Huxley, who has aided me in every possible way. It was signed by twelve good men, and you would have been gratified if you had seen how strongly they expressed themselves on your claims.

The Duke of Argyll, to whom I sent the memorial, wrote a private note to Mr. Gladstone. The memorial was sent in only on January 5th, and $I$ have just received a note in Mr. Gladstone's own handwriting, in which he says: "I lose no time in apprising you that although the Fund is moderate and at present poor, I shall recommend $\mathrm{Mr}$. Wallace for a pension of $£ 200$ a year." I will keep this note carefully, as, if the present Government were to go 


\section{Alfred Russel Wallace}

out, I do not doubt that it would be binding on the next Government.

I hope that it will give you some satisfaction to see that not only every scientific man to whom I applied, but that also our Government appreciated your lifelong scientific labour.-Believe me, my dear Wallace, yours sincerely,

CH. DaRwin.

I should expect that there will be some delay before you receive an official announcement.

Pen-y-bryn, St. Peter's Road, Croydon. January 8, 1881.

My dear Darwin,-I need not say how very grateful I am to you for your constant kindness, and especially for the trouble you have taken in recommending me to $\mathrm{Mr}$. Gladstone. It is also, of course, very gratifying to hear that so many eminent men have so good an opinion of the little scientific work I have done, for I myself feel it to be very little in comparison with that of many others.

The amount you say Mr. Gladstone proposes to recommend is considerably more than I expected would be given, and it will relieve me from a great deal of the anxieties under which I have laboured for several years. To-day is my fifty-eighth birthday, and it is a happy omen that your letter should have arrived this morning.

I presume after I receive the official communication will be the proper time to thank the persons who have signed the memorial in my favour. I do not know whether it is the proper etiquette to write a private letter of thanks to Mr. Gladstone, or only a general official one. Whenever I hear anything from the Government I will let you know.

Again thanking you for your kindness, believe me yours very faithfully,

ALFRED R. WALLACE. 


\section{The Wallace-Darwin Correspondence}

Down, Beckenham, Kent. January 10, 1881.

My dear Wallace,-I am heartily glad that you are pleased about the memorial.

I do not feel that my opinion is worth much on the point which you mention. A relation who is in a Government office and whose judgment, I think, may be fully trusted, felt sure that if you received an official announcement without any private note, it ought to be answered officially, but if the case were mine, I would express whatever I thought and felt in an official document. His reason was that Gladstone gives or recommends the pension on public grounds alone.

If the case were mine I would not write to signers of the memorial, because I believe that they acted like so many jurymen in a claim against the Government. Nevertheless, if I met any of them or was writing to them on any other subject, I should take the opportunity of expressing my feelings. I think you might with propriety write to Huxley, as he entered so heartily into the scheme and aided in the most important manner in many ways.

Sir J. Lubbock called here yesterday and Mr. F. Balfour came here with one of my sons, and it would have pleased you to see how unfeignedly delighted they were at my news of the success of the memorial.

I wrote also to tell the Duke of Argyll of the success, and he in answer expressed very sincere pleasure.-My dear Wallace, yours very sincerely,

CH. Darwin.

Pen-y-bryn, St. Peter's Road, Croydon. January 29, 1881.

My dear Darwin,-Yours just received was very welcome, and the delay in its reaching me is of no importance whatever, as, having seen the announcement of the Queen's approval of the pension, of course I felt it was safe. The 


\section{Alfred Russel Wallace}

antedating of the first payment is a very liberal and thoughtful act; but $I$ do not think it is any way excep. tional as regards myself. I am informed it is the custom because, as no payment is made after the death of the person, if the first payment were delayed the proposed recipient might die before the half-year (or quarter-day) and thus receive nothing at all.

I suppose you sent the right address to Mr. Seymour. I have not yet heard from him, but I daresay I shall during the next week.

As I am assured both by Miss Buckley and by Prof. Huxley that it is to you that $I$ owe in the first place this great kindness, and that you have also taken an immense amount of trouble to bring it to so successful issue, I must again return you my best thanks, and assure you that there is no one living to whose kindness in such a matter I could feel myself indebted with so much pleasure and satisfaction. -Believe me, dear Darwin, yours very faithfully,

ALFRED R. WALLACE.

Down, Beckenham, Kent. July 9.

My dear Wallace,-Dr. G. Krefft has sent me the enclosed from Sydney. A nurseryman saw a caterpillar feeding on a plant and covered the whole up, but, when he searched for the cocoon [pupa], was long before he could find it, so good was its imitation, in colour and form, of the leaf to which it was attached.

I hope that the world goes well with you. Do not trouble yourself by acknowledging this.-Ever yours,

Ch. Darwin.

Accompanying this letter, which has been published in "Darwin and Modern Science" (1909), was a photograph of the chrysalis (Papilio sarpedon choredon) attached to a 316 


\section{The Wallace-Darwin Correspondence}

leaf of its food-plant. Many butterfly pupæ are known to have the power of individual adjustment to the colours of the particular food-plant or other normal environment; and it is probable that the Australian Papilio referred to by Darwin possesses this power.

Nutwood Cottage, Frith Hill, Godalming. July 9, 1881.

My dear Darwin,-I am just doing, what I have rarely if ever done before-reading a book through a second time immediately after the first perusal. I do not think I have ever been so attracted by a book, with perhaps the exception of your "Origin of Species" and Spencer's "First Principles" and "Social Statics." I wish therefore to call your attention to it, in case you care about books on social and political subjects, but here there is also an elaborate discussion of Malthus's "Principles of Population," to which both you and I have acknowledged ourselves indebted. The present writer, Mr. George, while admitting the main principle as self-evident and as actually operating in the case of animals and plants, denies that it ever has operated or can operate in the case of man, still less that it has any bearing whatever on the vast social and political questions which have been supported by. a reference to it. He illustrates and supports his views with a wealth of illustrative facts and a cogency of argument which I have rarely seen equalled, while his style is equal to that of Buckle, and thus his book is delightful reading. The title of the book is "Progress and Poverty." It has gone through six editions in America, and is now published in England by Kegan Paul. It is devoted mainly to a brilliant discussion and refutation of some of the most widely accepted maxims of political economy, such as the relation of wages and capital, the nature of rent and interest, the laws of distribution, etc., but all treated as 


\section{Alfred Russel Wallace}

parts of the main problem as stated in the title-page, "An Enquiry into the Cause of Industrial Depressions and of Increase of Want with Increase of Wealth." It is the most startling novel and original book of the last twenty years, and if I mistake not will in the future rank as making an advance in political and social science equal to that made by Adam Smith a century ago.

I am here settled in my little cottage engaged in the occupation I most enjoy-making a garden, and admiring the infinite variety and beauty of vegetable life. I am out of doors all day and hardly read anything. As the long evenings come on I shall get on with my book on the "Land Question," in which I have found a powerful ally in Mr. George.

Hoping you are well, believe me, yours most faithfully, ALFRed R. WALLACE.

The following is the last letter Wallace received from Darwin, who died on Wednesday, April 19, 1882, in the seventy-fourth year of his age.

Down, Beckenham, Kent. July 12, 1881.

My dear Wallace,-I have been heartily glad to get your note and hear some news of you. I will certainly order "Progress and Poverty," for the subject is a most interesting one. But I read many years ago some books on political economy, and they produced a disastrous effect on my mind, viz. utterly to distrust my own judgment on the subject and to doubt much everyone else's judgment! So I feel pretty sure that Mr. George's book will only make my mind worse confounded than it is at present. I, also, have just finished a book which has interested me greatly, but whether it would interest anyone else I know not: it is "The Creed of Science," by W. Graham, A.M. Who 


\section{The Wallace-Darwin Correspondence}

and what he is I know not, but he discusses many great subjects, such as the existence of God, immortality, the moral sense, the progress of society, etc. I think some of his propositions rest on very uncertain foundations, and I could get no clear idea of his notions about God. Notwithstanding this and other blemishes, the book has interested me extremely. Perhaps I have been to some extent deluded, as he manifestly ranks too high what I have done.

I am delighted to hear that you spend so much time out of doors and in your garden; for with your wonderful power of observation you will see much which no one else has seen. From Newman's old book (I forget the title) about the country near Godalming, it must be charming.

We have just returned home after spending five weeks on Ullswater : the scenery is quite charming; but I cannot walk, and everything tires me, even seeing scenery, talking with anyone or reading much. What $I$ shall do with my few remaining years of life I can hardly tell. I have everything to make me happy and contented, but life has become very wearisome to me. I heard lately from Miss Buckley in relation to Lyell's Life, and she mentioned that you were thinking of Switzerland, which I should think and hope you will enjoy much.

I see that you are going to write on the most difficult political question, the Land. Something ought to be donebut what is to rule? I hope that you will [not] turn renegade to natural history; but I suppose that politics are very tempting.

With all good wishes for yourself and family, believe me, my dear Wallace, yours very sincerely,

Charles Darwin.

Wallace's last letter to Darwin was written in October, 1881 : 


\section{Alfred Russel Wallace}

Nutwood Cottage, Frith Hill, Godalming. October 18, 1881.

My dear Darwin,-I have delayed writing to thank you for your book on Worms till I had been able to read it, which I have now done with great pleasure and profit, since it has cleared up many obscure points as to the apparent sinking or burying of objects on the surface and the universal covering up of old buildings. I have hitherto looked upon them chiefly from the gardener's point of view -as a nuisance, but I shall tolerate their presence in the view of their utility and importance. A friend here to whom I am going to lend your book tells me that an agriculturist who had been in West Australia, near Swan River, told him many years ago of the hopelessness of farming there, illustrating the poverty and dryness of the soil by saying, "There are no worms in the ground."

I do not see that you refer to the formation of leafmould by the mere decay of leaves, etc. In favourable places many inches or even feet of this is formed-I presume without the agency of worms. If so, would it not take part in the formation of all mould? and also the decay of the roots of grasses and of all annual plants, or do you suppose that all these are devoured by worms? In reading the book I have not noticed a single erratum.

I enclose you a copy of two letters to the Mark Lane Express, written at the request of the editor, and which will show you the direction in which $I$ am now working, and in which $I$ hope to do a little good.-Believe me your: very faithfully,

Alfrem R. Wallace.

$$
A M R=1917
$$

Printed ay Cassell \& Company, Limited, la Belle Sauvage, London, E.C. FI5.316 

THE UNIVERSITY OF MICHIGAN

DATE DUE

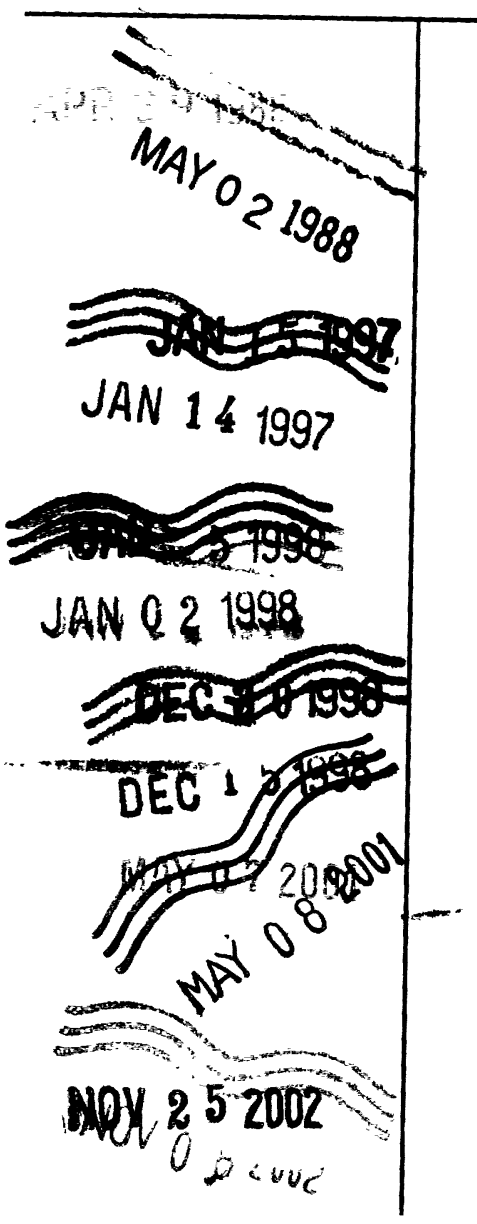




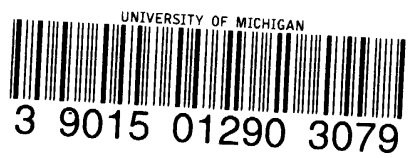

\section{DO NOT REMOVE OR


